Role of transport systems in cortisol release from human adrenal cells

\author{
Dissertation \\ zur Erlangung des Doktorgrades \\ der Mathematisch-Naturwissenschaftlichen Fakultäten \\ der Georg-August-Universität zu Göttingen
}

vorgelegt von

Abdul Rahman Asif

aus Gujrat, Pakistan

Göttingen 2004 
D7

Referent: Prof. Dr. R. Hardeland

Korreferent: Prof. Dr. D. Gradmann

Tag der mündlichen Prüfung: 


\title{
To
}

\section{My parents}

in loving memory of my

\author{
grandma!
}

She could not wait! 
ABSTRACT IV

LIST OF ABBREVIATIONS VI

\section{INTRODUCTION} 1

1.1 THE ADRENAL GLAND ANATOMY

1.2 ADRENAL GLAND HORMONES...

P

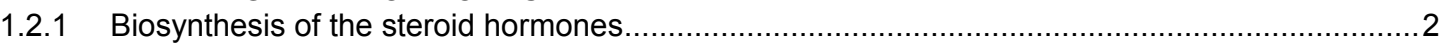

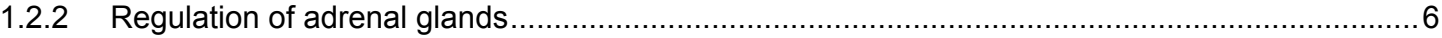

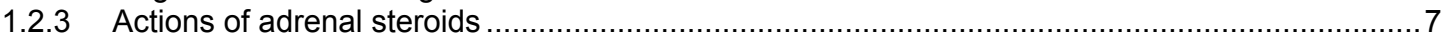

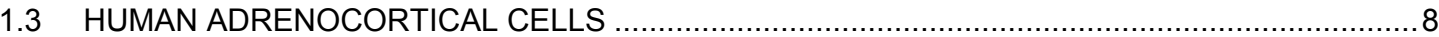

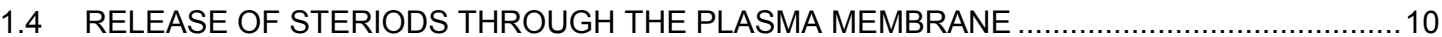

1.4.1 Organic anion transporter (OAT) family ................................................................... 11

1.4.2 Organic anion transporter polypeptide (OATP) family ................................................... 13

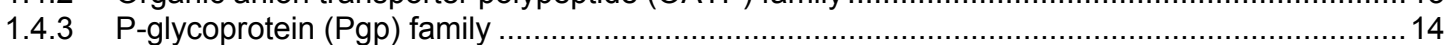

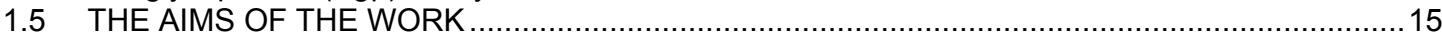

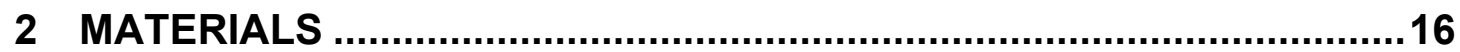

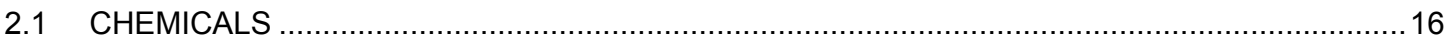

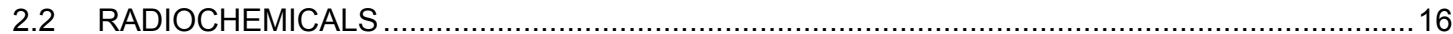

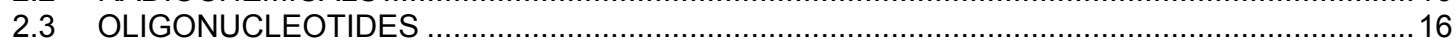

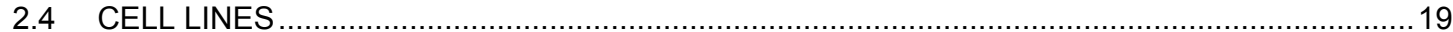

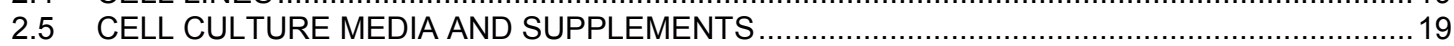

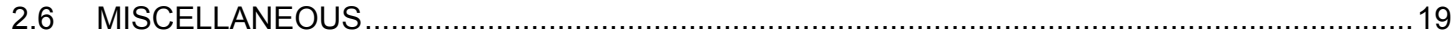

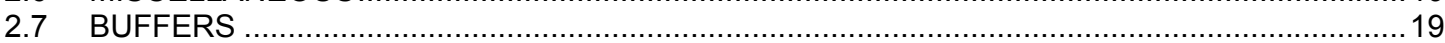

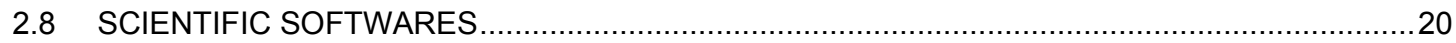

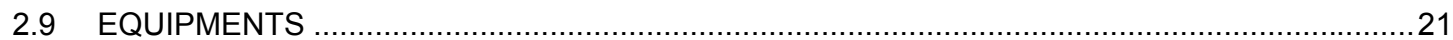

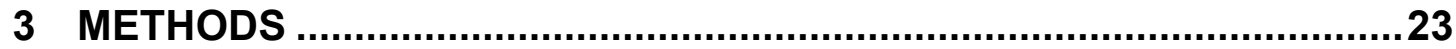

3.1 AMPLIFICATION AND QUANTIFICATION OF GENE OF INTEREST BY PCR .......................23

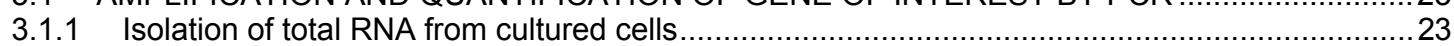

3.1.2 Isolation of total RNA from human adrenal tissues......................................................... 23

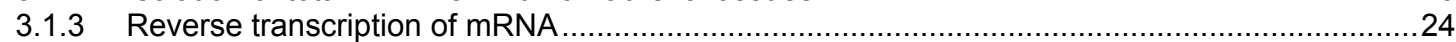

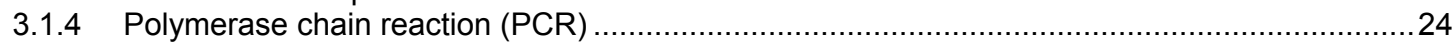

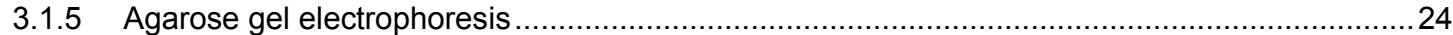

3.1.6 Purification of PCR product from agarose gel .............................................................. 25

3.1.7 Sequencing of the PCR product (non-radioactive dye terminated sequencing of DNA) ............25

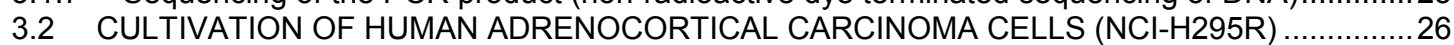

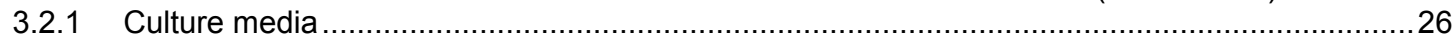

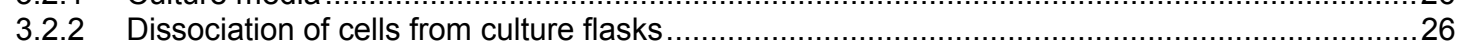

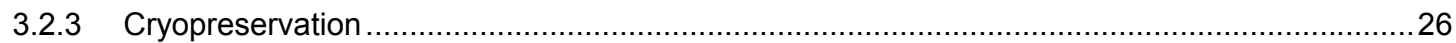

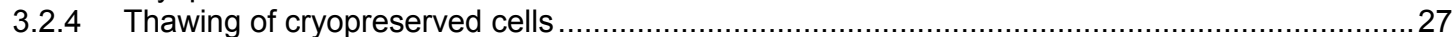

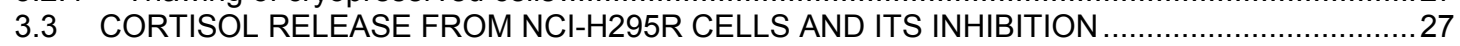

3.3.1 Determination of cortisol by radioimmunoassay (RIA) .................................................... 27

3.4 UPTAKE OF RADIOACTIVE SUBSTANCES INTO THE NCI-H295R CELLS ..............................28

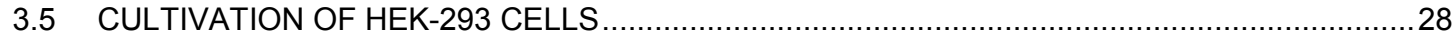

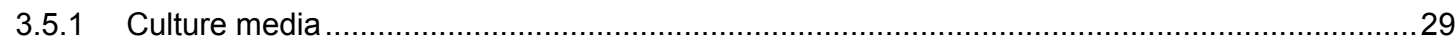

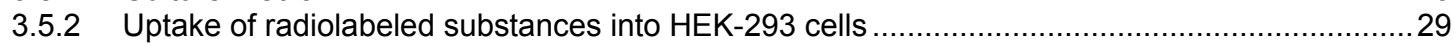

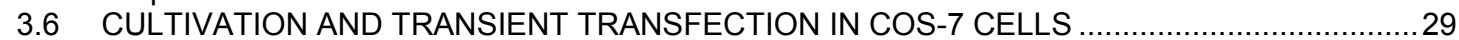

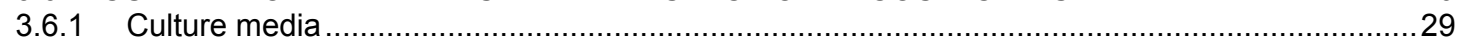

3.6.2 Transfection of COS-7 cells by electroporation .............................................................. 30

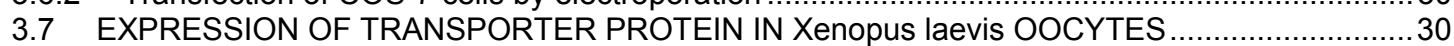

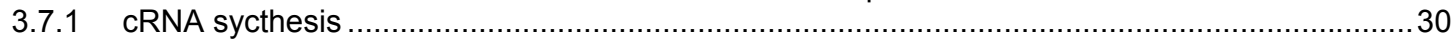

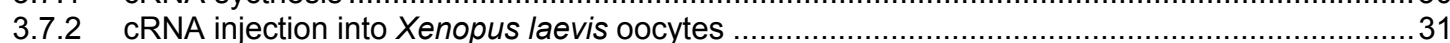

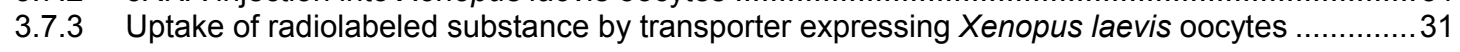




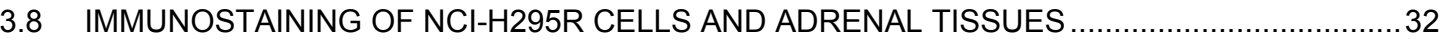

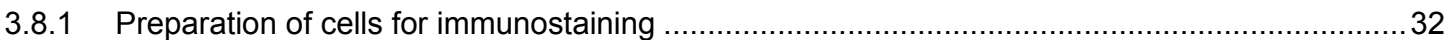

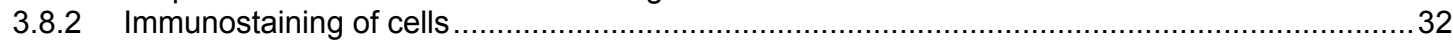

3.8.3 Immunostaining of paraffin embedded adrenal tissue sections ..........................................33

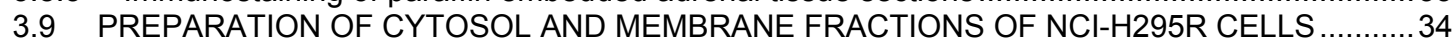

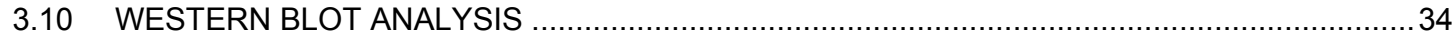

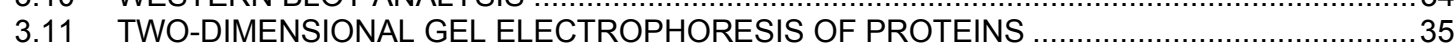

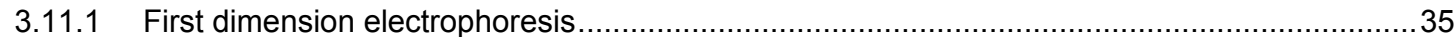

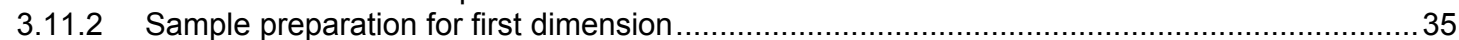

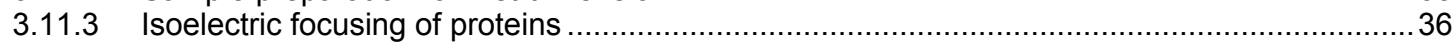

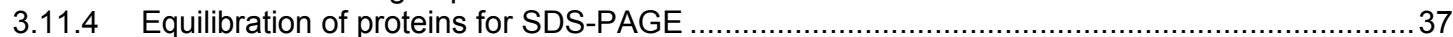

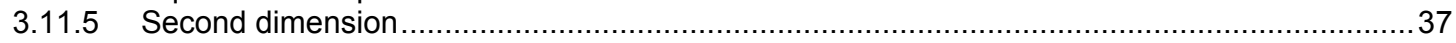

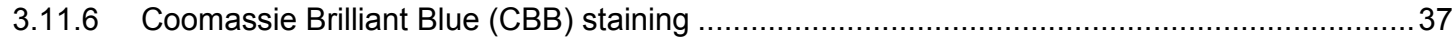

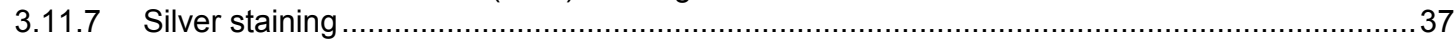

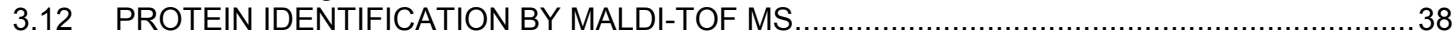

3.12.1 In-gel digestion and preparation of proteins and proteolytic fragments for MALDI-TOF ...........40

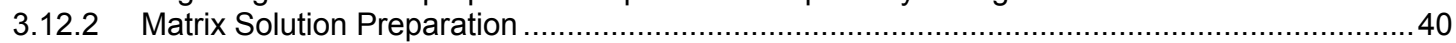

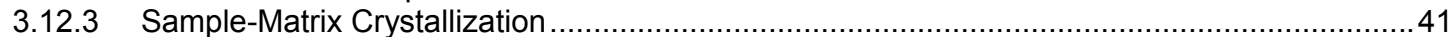

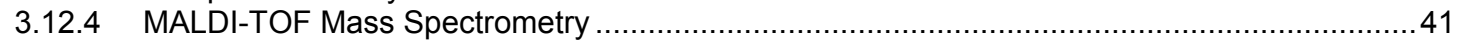

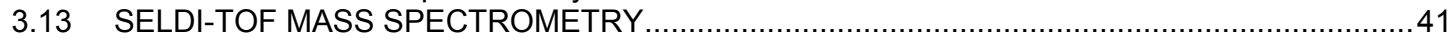

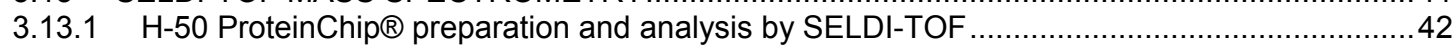

4 RESULTS

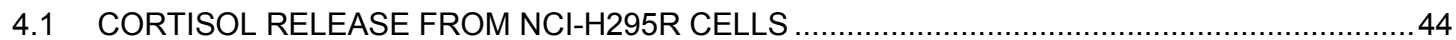

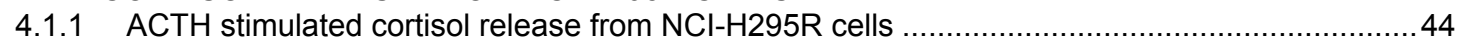

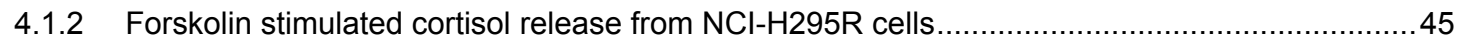

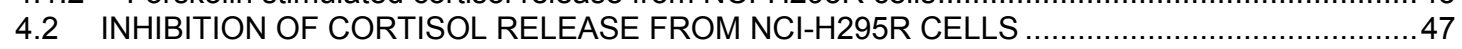

4.2.1 Inhibition of cortisol release by probenecid in $\mathrm{NCl}-\mathrm{H} 295 \mathrm{R}$ cells .......................................47

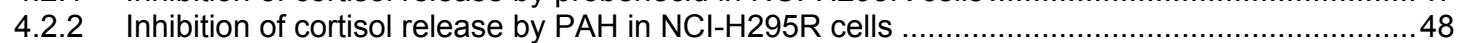

4.2.3 Inhibition of cortisol release by glutarate in $\mathrm{NCl}-\mathrm{H} 295 \mathrm{R}$ cells .........................................49

4.2.4 Inhibition of cortisol release by cimetidine in NCl-H295R cells .............................................49 49

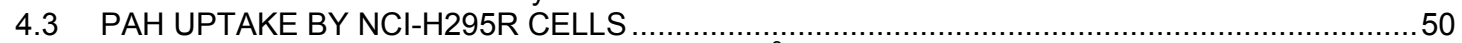

4.3.1 Time-course and temperature dependence of $\left[{ }^{3} \mathrm{H}\right] \mathrm{PAH}$ uptake into $\mathrm{NCl}-\mathrm{H} 295 \mathrm{R}$ cells. .............50

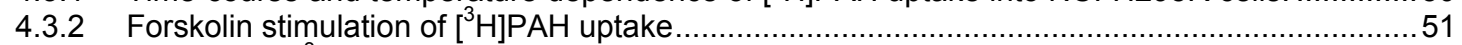

4.3.3 Inhibition of $\left[{ }^{3} \mathrm{H}\right] \mathrm{PAH}$ uptake into $\mathrm{NCl}-\mathrm{H} 295 \mathrm{R}$ cells by probenecid ......................................52

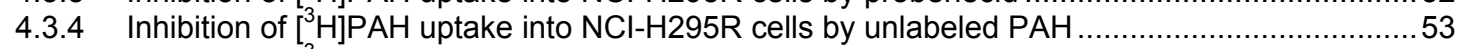

4.3.5 Inhibition of $\left[{ }^{3} \mathrm{H}\right] \mathrm{PAH}$ uptake by estrone sulfate into $\mathrm{NCl}-\mathrm{H} 295 \mathrm{R}$ cells .................................54

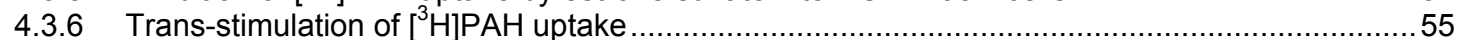

4.4 EXPRESSION OF HUMAN OATS, OATPS AND STEROID BIOSYNTHESIS ENZYMES mRNA IN NCI-H295R CELLS, HUMAN NORMAL AND TUMOR ADRENAL TISSUES ..........................58

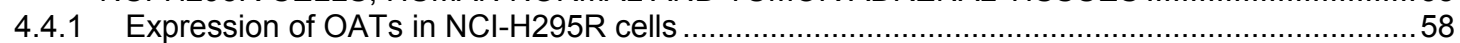

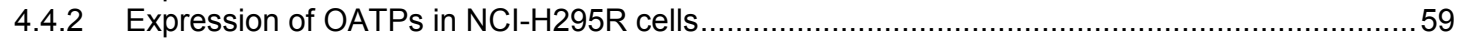

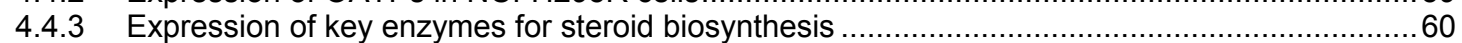

4.5 CORTISOL UPTAKE IN HUMAN OAT EXPRESSING Xenopus laevis OOCYTES....................62

4.5.1 Radiolabeled cortisol uptake in human OAT1 and OAT2 expressing Xenopus laevis oocytes ..62

4.5.2 Radiolabeled cortisol uptake experiments in human OAT4 expressing Xenopus laevis oocytes63

4.5.3 Radiolabeled cortisol uptake in human OAT3 expressing Xenopus laevis oocytes ..................64

4.5.4 Concentration dependent inhibition of radiolabeled cortisol uptake by unlabeled cortisol in hOAT3 expressing Xenopus laevis oocytes

4.5.5 Inhibition of radiolabeled estrone sulfate uptake in human OAT3 expressing Xenopus laevis oocytes by unlabeled cortisol ....

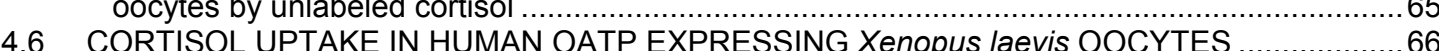

4.7 RADIOLABELED SUBSTANCES UPTAKE IN hOATS STABLY TRANSFECTED HEK-293 CELLS

4.7.1 Inhibition of $\left.{ }^{3} \mathrm{H}\right] \mathrm{PAH}$ uptake by unlabeled cortisol in hOAT1 stably transfected HEK-293 cells. 68

4.7.2 Inhibition of $\left[{ }^{3} \mathrm{H}\right.$ ]estrone sulfate uptake by unlabeled cortisol in HEK-293 cells stably transfected with hOAT3

4.7.3 [ $\left.{ }^{3} \mathrm{H}\right] \mathrm{DHEAS}$ uptake into HEK-293 cells transfected with hOAT4 and inhibition by unlabeled cortisol.....

4.8 ESTRONE SULFATE UPTAKE BY NCIH295R CELLS

$4.1 \ldots$

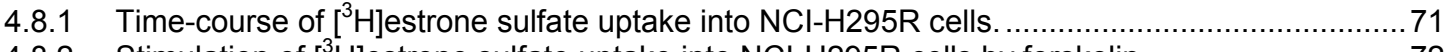

4.8.2 Stimulation of $\left[{ }^{3} \mathrm{H}\right]$ estrone sulfate uptake into $\mathrm{NCl}-\mathrm{H} 295 \mathrm{R}$ cells by forskolin ............................72

4.8.3 Inhibition of $\left[{ }^{3} \mathrm{H}\right]$ estrone sulfate uptake into $\mathrm{NCl}-\mathrm{H} 295 \mathrm{R}$ cells by unlabeled estrone sulfate and DHEAS. 
4.8.4 Inhibition of $\left[{ }^{3} \mathrm{H}\right]$ estrone sulfate uptake into $\mathrm{NCl}-\mathrm{H} 295 \mathrm{R}$ cells by cortisol ..............................75

4.8.5 Inhibition of $\left[{ }^{3} \mathrm{H}\right]$ estrone sulfate uptake into $\mathrm{NCl}-\mathrm{H} 295 \mathrm{R}$ cells by inhibitors of the OAT family ....75

4.8.6 Trans-stimulation of $\left[{ }^{3} \mathrm{H}\right]$ estrone sulfate uptake into $\mathrm{NCl}-\mathrm{H} 295 \mathrm{R}$ cells by glutarate and cortisol 77

4.9 ROLE OF MDR1 IN CORTISOL RELEASE FROM HUMAN ADRENOCORTICAL CELLS ..........78

4.9.1 Expression of MDR1 in NCl-H295R cells, normal and tumor adrenal tissues ...........................79

4.9.2 Concentration-dependent inhibitory effect of MDR1 inhibitors on cortisol release from NCl-

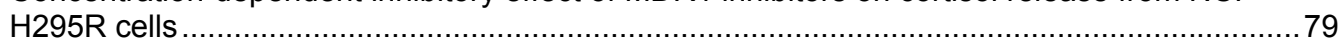

4.10 DHEAS INDUCED CORTISOL RELEASE FROM NCI-H295R CELLS .................................81

4.10.1 Effect of DHEAS and estrone sulfate on cortisol release from $\mathrm{NCl}-\mathrm{H} 295 \mathrm{R}$ cells ....................81

4.11 EFFECT OF FORSKOLIN AND DHEAS STIMULATION ON mRNA EXPRESSION OF HUMAN ORGANIC ANION TRANSPORTERS

4.12 EFFECT OF FORSKOLIN AND DHEAS STIMULATION ON mRNA EXPRESSION OF KEY ENZYMES OF STEROID BIOSYNTHESIS ................................................................... 85

4.13 IMMUNOBLOTTING ANALYSIS FOR hOAT3 PROTEIN EXPRESSION IN NCI-H295R CELLS...

4.14 IMMUNOFLUORESCENCE STUDIES FOR hOAT3 PROTEIN EXPRESSION IN NCI-H295R

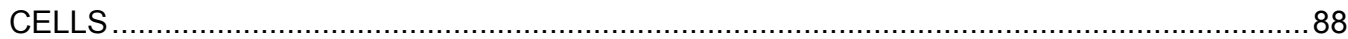

4.15 SELDI-TOF ANALYSIS OF NCI-H295R CELLS

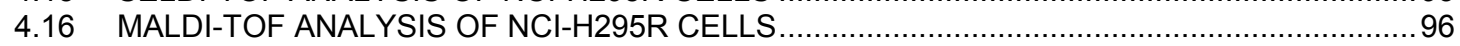

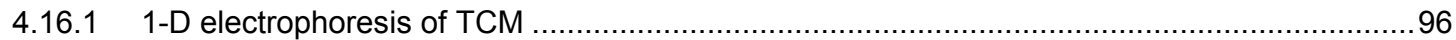

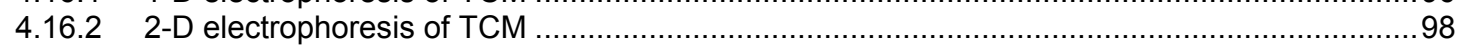

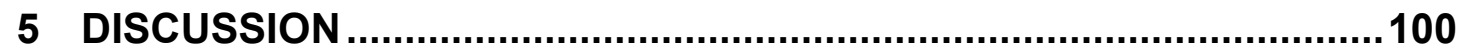

5.1 RELEASE OF STEROID HORMONES FROM HUMAN ADRENOCORTICAL CELLS..............100

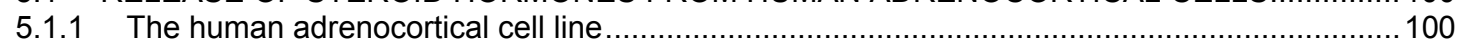

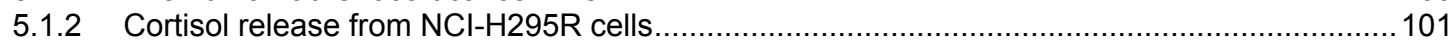

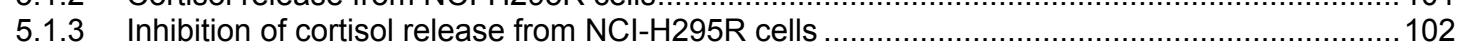

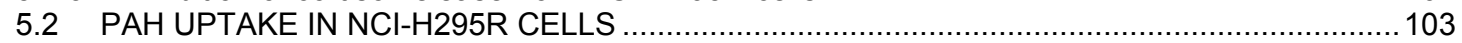

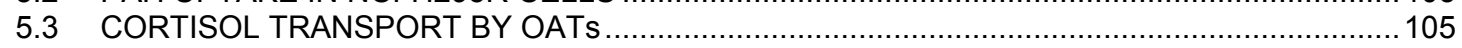

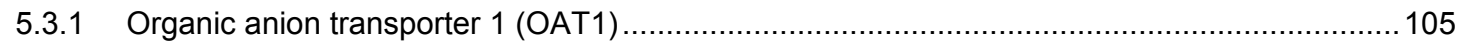

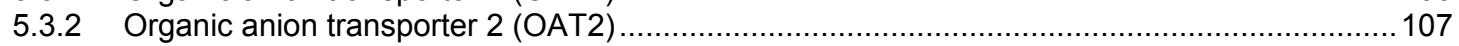

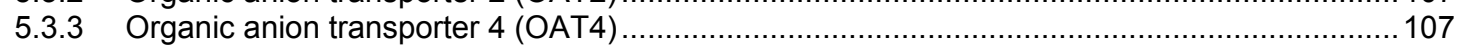

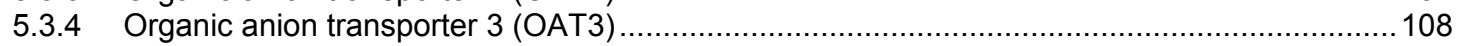

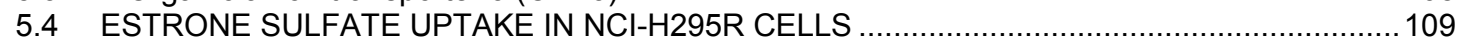

5.5 ROLE OF OATPS IN CORTISOL RELEASE FROM NCI-H295R CELLS ................................111

5.6 ROLE OF MDR1 IN CORTISOL RELEASE FROM NCI-H295R CELLS ...............................112

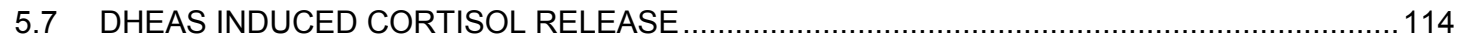

5.7.1 Effect of DHEAS treatment of cortisol release from $\mathrm{NCl}-\mathrm{H} 295 \mathrm{R}$ cells .................................114

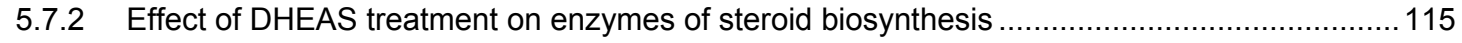

5.7.3 Effect of DHEAS treatment on organic anion transporters .......................................... 115

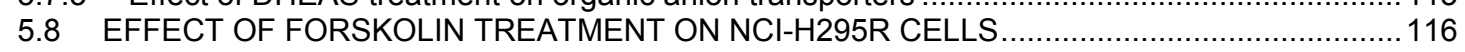

5.8.1 Effect of forskolin treatment on steroid biosynthesis enzymes ....................................... 116

5.8.2 Effect of forskolin treatment on organic anion transporters ............................................. 116

5.9 EFFECT OF FORSKOLIN AND DHEAS TREATMENT ON NCI-H295R CELLS AT PROTEOME

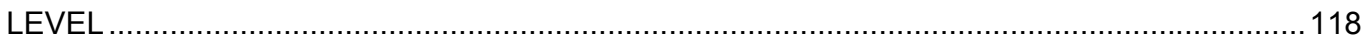

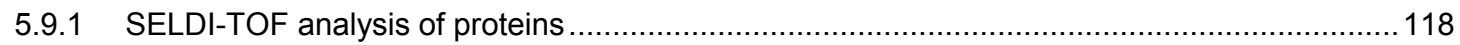

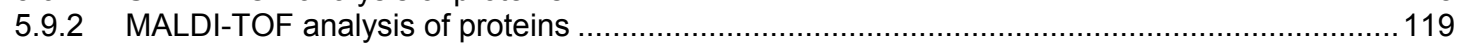

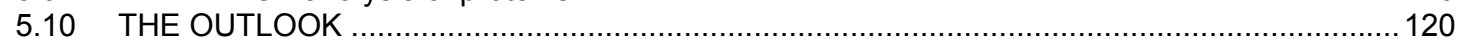

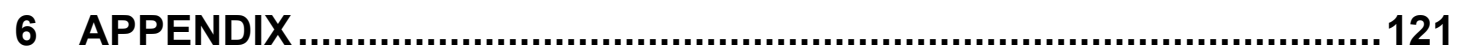

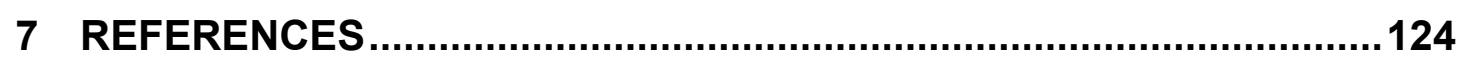

ACKNOWLEDGMENTS .................................................................. 135

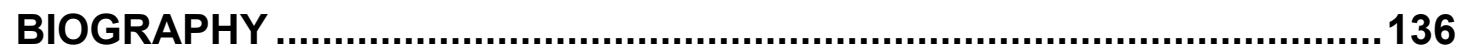




\section{ABSTRACT}

Adrenal steroid hormones (e.g., cortisol) play a pivotal role in the regulation and maintenance of metabolic homeostasis. The secretion of glucocorticoids from adrenocortical cells into the blood is poorly understood. It has long been postulated that this occurs via simple diffusion, based on the lipophilic structure of steroid hormones. Previously, it has been demonstrated that cortisol release from and uptake of $\left[{ }^{3} \mathrm{H}\right] \mathrm{PAH}$ into bovine adrenocortical cells showed physiological characteristics similar to the renal/organic anion exchanger OAT1. In this study we investigated whether an organic anion transporter (OAT) may play a role in cortisol release from the human adrenal cell line, $\mathrm{NCl}-\mathrm{H} 295 \mathrm{R}$. Basal $24 \mathrm{~h}$ cortisol secretion increased up to threefold by pretreatment with $\mathrm{ACTH}$, and up to thirtyfold with forskolin. Incubation for $24 \mathrm{~h}$ with PAH partially inhibited cortisol release, while cimetidine inhibition was relatively pronounced, indicating some differences between $\mathrm{NCl}-\mathrm{H} 295 \mathrm{R}$ cells and bovine adrenal cells. RT-PCR did not reveal an expression of human OAT1 and OAT2, but OAT3 and OAT4 mRNA was detected in NCl-H295R cells as well as in normal human adrenal tissue. The studies with HEK-293 cells stably transfected with human OAT1, OAT3, and OAT4 showed a low interaction of cortisol with hOAT1 and hOAT4 as compared to hOAT3. When human OAT1, OAT3, and OAT4 were expressed in Xenopus laevis oocytes, only hOAT3 showed $\left[{ }^{3} \mathrm{H}\right]$ cortisol uptake beyond non-expressing control oocytes. Cortisol uptake was saturable with an apparent $\mathrm{K}_{\mathrm{t}}$ value of $2.4 \mu \mathrm{M}$, and $\left[{ }^{3} \mathrm{H}\right]$ estrone sulfate uptake was inhibited by unlabeled cortisol with an $\mathrm{IC}_{50}$ of $15.6 \mu \mathrm{M}$. The experiments in $\mathrm{NCl}$ $\mathrm{H} 295 \mathrm{R}$ cells showed a saturable $\left[{ }^{3} \mathrm{H}\right]$ estrone sulfate uptake, a potent substrate of hOAT3, with a $\mathrm{K}_{\mathrm{i}}$ value of $9.8 \mu \mathrm{M}$. The inhibition with unlabeled DHEAS and cortisol resulted in $\mathrm{IC}_{50}$ values of 10.6 and $38.9 \mu \mathrm{M}$, respectively. The $\left[{ }^{3} \mathrm{H}\right.$ ]estrone sulfate uptake in $\mathrm{NCl}-\mathrm{H} 295 \mathrm{R}$ cells was decreased by potent inhibitors of hOAT3, i.e. probenecid, cimetidine, and glutarate. In $\mathrm{NCl}-\mathrm{H} 295 \mathrm{R}$ cells, $\left[{ }^{3} \mathrm{H}\right]$ estrone sulfate uptake was trans-stimulated by preloading with glutarate or cortisol. Likewise, $\left[{ }^{3} \mathrm{H}\right] \mathrm{PAH}$ uptake was trans-stimulated by preloading the cells with $\mathrm{PAH}$, glutarate, or cortisol. The $24 \mathrm{~h}$ forskolin treatment significantly increased $\left[{ }^{3} \mathrm{H}\right]$ estrone sulfate and $\left[{ }^{3} \mathrm{H}\right] \mathrm{PAH}$ uptake in NCl-H295R cells. Semi-quantitative RT-PCR showed an increased hOAT3 mRNA expression after pretreatment with forskolin. Forskolin-treatment induced a significant increase in the enzymes of steroids biosynthesis, i.e. StAR, CYP17, 3ßHSD, and CYP21A2. Immunolocalization studies for hOAT3 resulted in expression of hOAT3 in NCl-H295R cells. There was a high increase in OAT3 expression by a $24 \mathrm{~h}$ treatment with forskolin. Our data suggests that OAT3 is functionally expressed 
in $\mathrm{NCl}-\mathrm{H} 295 \mathrm{R}$ cells and is able to perform cortisol/anion exchange. Thereby, OAT3 may - among other release mechanisms - contribute to cortisol efflux from human adrenal cells. 


\section{LIST OF ABBREVIATIONS}

${ }^{\circ} \mathrm{C}$

$\mu \mathrm{M}$

APS

ATP

bp

BSA

BSP

CAMP

cDNA

cRNA

C-terminus

DHEAS

DMSO

dNTP

DTT

E.coli

EDTA

e.g.

ES

FCS

fig.

g

GAPDH

$\mathrm{h}$

HEK-293

HEPES

hOAT

$\mathrm{kDa}$

$\mathrm{Km}$

$\mathrm{L}$

LiAc

$\mathrm{M}$

$\mathrm{mAb}$

MALDI-MS
Celsius

micromolar

ammonium persulfate

adenosine triphosphate

base pairs

bovine serum albumin

bromosulfophthalein

cyclic adenosine-3',5'-monophosphate

complementary deoxynucleotide acid

complementary RNA

carboxy-terminus

dehydroepiandosterone sulfate

dimethyl sulfoxid

deoxyribonucleotide phosphate

dithiothreitol

escherichia coli

ethylendinitrilo-N, N, N', N'-tetra- acetic acid

for example

estrone sulfate

fetal calf serum

figure

gram

glyceraldehyde-3-phosphate dehydrogenase

hour

human embryonic kidney cell line

2-(4-2-hydroxylethyl)-poperazinyl-1-ethansulfonat

human organic anion transporter

kilodalton

Michaelis Menten constant

liter

lithium acetate

molar (moles per litre)

monocolonal antibody

matrix-assisted laser desorption/ionisation time of flight mass spectrometry 


\begin{tabular}{|c|c|}
\hline $\mathrm{ml}$ & millilitre \\
\hline $\mathrm{mM}$ & millimolar \\
\hline mRNA & messenger RNA \\
\hline MRP2 & multiple drug resistance-associated protein 2 \\
\hline MTT & 3-(4,5-dimethylthiazole-2-yl)-2,5-diphenyl tetrazolium bromide \\
\hline N-terminus & amino-terminus \\
\hline OATP & organic anion transporting polypeptide \\
\hline ОСТ & organic cation transporter \\
\hline OD & optical density \\
\hline ORI & oocyte Ringer's solution \\
\hline PAGE & polyacrylamide gel electrophoresis \\
\hline $\mathrm{PAH}$ & para-aminohippurate \\
\hline PBS & phosphate-buffered saline \\
\hline PCR & polymerase chain reaction \\
\hline PMSF & phenylmethyl-sulfonylfluoride \\
\hline RNA & ribonucleic acid \\
\hline RNase & ribonuclease \\
\hline rpm & revolutions per minute \\
\hline RT & room temperature \\
\hline RT-PCR & reverse transcription polymerase chain reaction \\
\hline SDS & sodium-dodecyl-sulfate \\
\hline SELDI-TOF-MS & $\begin{array}{l}\text { surface enhanced laser desorption ionisation- time of flight- } \\
\text { mass spectrometry }\end{array}$ \\
\hline SEM & standard error of the mean \\
\hline TAE & tris-acetate-EDTA \\
\hline TBE & tris-borate-EDTA \\
\hline TBS & tris-buffered saline \\
\hline TCA & trichloroacetic acid \\
\hline TEMED & N', N', N', N'-tetramethyldiamine \\
\hline Tris & tris-(hydroxymethyl)-aminomethane \\
\hline Tween-20 & polyoxyethylen-sorbit-monolaurate \\
\hline$U$ & unit (enzymatic activity) \\
\hline UV & ultraviolet \\
\hline V & volts \\
\hline
\end{tabular}




\section{INTRODUCTION}

\subsection{THE ADRENAL GLAND ANATOMY}

The human adrenal glands are endocrine glands of roughly pyramidal shape. They are situated above and occasionally attached to the upper pole of the kidney, but are usually surrounded by peri-renal fat. The adrenal glands consist of two endocrine tissues of different embryological origin: the primarily steroid producing adrenocortical tissue derives from the mesodermal lining of the colon, and the catecholamine producing chromaffine cells originate in the neural crest and migrate into the centre of the cortical tissue during fetal development (Harvey 1996). Knowledge of the adrenal cortex began with the observations of a physician, J. Arnold (Arnold 1866), 149 years ago. In most mammals the adrenal cortex consists of three zones, varying in their morphological features and the steroid hormones they produce (Arnold 1866). Just beneath the hard connective tissue, the outer zona glomerulosa is found, which is made up of whorls of cells that are continuous with the columns of cells, which form the zona fasciculata beneath. These columns are separated by venous sinus. The inner portion of the zona fasciculata merges into the zona reticularis, where the cell columns become interlaced in a network. The zona glomerulosa makes up $15 \%$ of the mass of the adrenal gland. The cells have smallelongated mitochondria, scant finely vesiculated smooth endoplasmic reticulum, occasional lipid inclusions, and few lysosomes, lipofusion granules, and microvilli. These gradually blend into typical fasciculata cells that contain small, spherical to ovoid mitochondria, abundant smooth and occasional rough endoplasmic reticulum arrayed as large vesicles in a honeycomb pattern, abundant lipid inclusions, increased number of lipofusion granules, and prominent microvilli. Zona reticularis cells have small, mostly ovoid mitochondria, densely packed smooth endoplasmic reticulum, rare lipid inclusions, abundant lipofusion granules, and numerous microvilli (Neville et al. 1982).

The adrenal cortex receives rich innervations, mainly in the region of the zona glomerulosa and the connective tissue capsule. The arterial blood reaches the adrenals form many small branches of the aorta, the inferior phrenic, renal, and intercostal arteries. More than sixty small branches form a subcapsular arteriolar plexus that drains into a rich array of radial capillaries, some of which penetrate deep into zona fasciculata. These vessels then create a dense sinusoidal plexus around the cells of the zona reticularis and from veins that transverse the medulla to empty 
into the central vein. There is no direct arterial blood supply to the zona fasciculata and reticularis (Neville et al. 1982). The arrangement of sinusoids within the gland is such that almost every cell of the adrenal cortex is in direct contact with a blood vessel. Blood flow through the adrenal is maintained independently of the changes in the systemic blood pressure (Vinson et al. 1992).

For many years it was the commonly held view that the nerve bundles passed through the cortex without branching. It is now widely accepted that the adrenal cortex receives rich innervations, mainly in the region of the zona glomerulosa and the connective tissue capsule. Efferent sympathetic axons, plexus preganglionic neurons and efferent parasympathetic axons branch off the posterior vagal trunk from a plexus medial to the adrenal, enter with the arterioles and traverse the cortex to the end in the medulla. Nerves that end at glomerulosa cells contain catecholamine and neuropeptide $Y$ (Kondo 1985). Nerve terminals have been found in close contact with both blood vessels and the adrenocortical cells, and it has been shown that certain neurotransmitters are able to influence blood flow and steroid secretion in the adrenal gland (Vinson et al. 1992).

\subsection{ADRENAL GLAND HORMONES}

The hormones of adrenal cortex are derivatives of cholesterol. There have been almost 50 different steroids recognized as adrenal cortex products, which cover a wide range of physiological activities. In most species, including the human, the most physiologically important of these corticosteroids are aldosterone, a mineralocorticoid, and cortisol, a glucocorticoid. The most abundant steroid produced by the adrenal cortex is an androgen, dehydroepiandrosterone sulphate (DHEAS). The adrenal cortex also produces estrogen, progesterone, and a wide range of precursors and metabolites of these steroids. In rats, which lack the 17a-hydroxylase activity, necessary for cortisol and androgen production, the major glucocorticoid is corticosterone, and there is also a reduced androgen production. The "youngest" member of the adrenal cortex steroid family is recognized as ouabain (Hinson et al. 1995; Nicholls et al. 1995). In the medulla, norepinephrine and epinephrine are major secretary products, which are derivatives of the amino acid tyrosine.

\subsubsection{Biosynthesis of the steroid hormones}

The precursor of steroid hormones is cholesterol, which is a 17-carbon steroid nucleus. The cells of the steroidogenic tissues can de novo synthesize cholesterol from acetate, mobilize the intracellular cholesterol ester pools, or import lipoprotein 
cholesterol from the plasma. Cholesterol is stored as cholesterol acetate in neutral lipid droplets, which serves as a pool of readily available cholesterol for corticosteroid biosynthesis (Vinson et al. 1992). About $80 \%$ of cholesterol is usually provided by circulating plasma lipoproteins as low-density lipoproteins (LDL) (Gwynne et al. 1982). There are species differences in the main steroid products secreted from the adrenal glands. Primates, dogs, hamster, and fish secrete mainly cortisol whereas corticosterone is the major glucocorticoids in mouse, rat, rabbit, bird, reptiles and amphibians due to lack of $17 \alpha$-hydroxylase (Bush 1953). Cholesterol is converted to steroid hormone intermediates and mature hormones by cytochrome P-450 enzymes

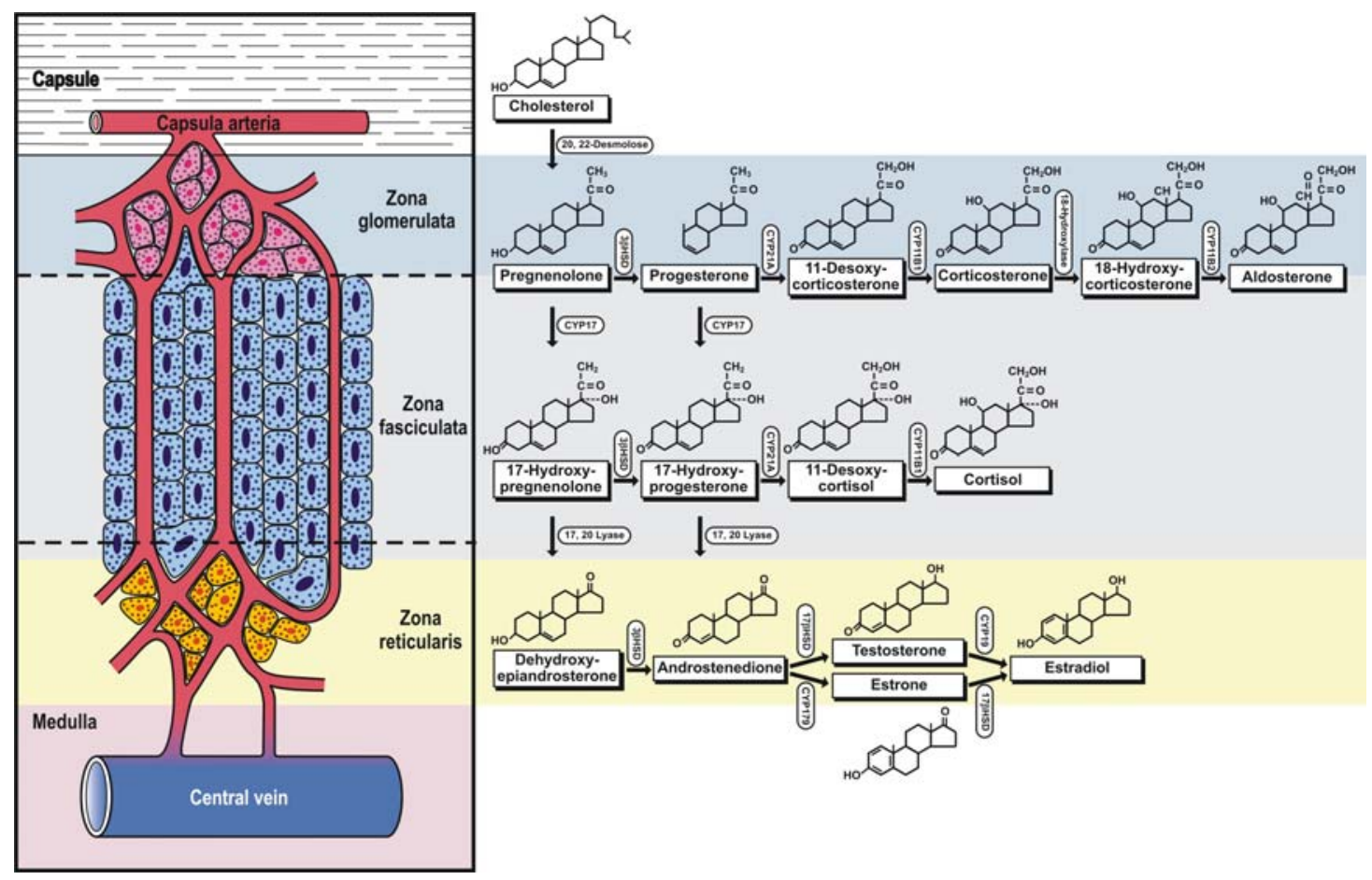

Figure 1.1 Major steroid biosynthesis pathways of adrenal glands. The figure shows the zonation in adrenal gland and major pathways of steroid biosynthes. The outmost hard connective tissue (white) is covering the zona glomerulosa (light blue), the products are mineralocorticoids specially aldosterone. The zona fasciculata (gray) is the most prominent area, and produces glucocorticoids, importantly cortisol. The inner zone of adrenal cortex is the zona reticularis (light yellow) which produces sex steroids, specially testosterone and estradiol. Just beyond the zona reticularis, the medulla starts. The intermediate products of steroid biosynthesis are written under ther structural formulas in square boxes. The respective members of cytochrome $\mathrm{P} 450$ family, which catalyze the reaction, are written in the boxes. (CYP11A1 $=$ side-chain cleavage enzyme desmolase, CYP17 $=17 \alpha$ hydroxylase $/ 17,20$ lyase, $3 \beta \mathrm{HSD}=3 \beta$-hydroxysteroid dehydrogenase, $\mathrm{CYP} 21 \mathrm{~A} 2=21-$ hydroxylase, $\mathrm{CYP11B1}=$ steroid 11-beta-hydroxylase, $\mathrm{CYP11B2}=11 \beta$-hydroxylase aldosterone synthase, 17ßHSD $=17$-ketosteroid reductase, and CYP19 $=19$ hydroxylase). Modified from Urban \& Fischer Physiologie. 
in the mitochondria and smooth endoplasmic reticulum. Synthesis begins in the mitochondria, continues in the endoplasmic reticulum, and is completed in the mitochondria. Therefore, shuttling of steroid hormone precursors between the mitochondria and cytoplasmic compartments is important in the multiple steps of hormone synthesis. The zone specific steroid biosynthesis pathways of adrenal gland are shown in the Figure 1.1.

The rate-limiting step in the steroidogenesis is cholesterol transport across the outer to the inner mitochondrial membranes and the CYP11A1 (20, 22 R-hydroxylase cholesterol side-chain cleavage) complex. For acute steroid biosynthesis, cholesterol has to be mobilized and delivered from the lipid droplets to the CYP11A1 complex, which is associated with the inner mitochondrial membrane. The protein factor responsible for this transport, and as such regulating the acute production of steroids, has been identified and named steroidogenic acute regulatory protein (StAR) (Zenkert et al. 2000). The definite mechanism of the acute regulation of steroidogenesis by StAR is not known yet, but there are two proposed mechanisms: the association of StAR with the outer mitochondrial membrane facilitates the import of cholesterol, or the import of StAR to the inner mitochondrial membrane is concomitant with cholesterol transport.

The first steroid hormone produced by cortical cells from cholesterol is pregnenolone by the action of mitochondrial cytochrome, side-chain cleavage enzyme desmolase (CYP11A1). This reaction is important since it is the second rate-limiting step of steroid hormone biosynthesis. This step is under the control of ACTH secreted by the pituitary gland. ACTH binds to cell membrane receptors linked to G-proteins and stimulates cytoplasmic CAMP and increases the availability of cholesterol to CYP11A1, which results in an increased pregnenolone synthesis (Rosol et al. 2001). Pregnenolone then passes from mitochondria to the endoplasmic reticulum for further metabolism. On the one hand, it can be converted directly to progesterone by $3 \beta$-hydroxysteroid dehydrogenase ( $3 \beta \mathrm{HSD})$. Alternatively it can be hydroxylated at the $17 \alpha$-position by $17 \alpha$-hydroxylase (CYP17) to produce 17a-hydroxypregnenolone. $17 \alpha$-hydroxypregnenolone can be converted to $17 \alpha$-hydroxyprogestrone by $3 \beta \mathrm{HSD}$ or to a C19 steroid, dehydroepiandrosterone, by the second isoform of $17 \alpha$ hydroxylase/17,20 lyase (CYP17). Dehydroepiandrosterone (DHEA) can also be converted by $3 \beta \mathrm{HSD}$ to adrostenedione, which serves as precursor of sex hormones. Progesterone or 17a-hydroxypregnenolone can be hydroxylated at the 21-position by 21-hydroxylase (CYP21A2), producing 11-deoxycorticosterone and 11hydroxycortisol, respectively. The products of CYP21A2 must re-enter the 
mitochondria, where the final steps of steroidogenesis in the adrenal cortex occur. The two isoforms of CYP11B; 11 $\beta$-hydroxylase/aldosterone synthase (CYP11B2) and 11-beta-hydroxylase (CYP11B1), catalyze the conversion of deoxycorticosterone and 11-deoxycortisol to the glucocorticoids; corticosterone and cortisol respectively. These reactions leading to the production of glucocorticoids and adrenal androgen take place in the zona fasciculata and zona reticularis, respectively. On the other hand, the outer zone of the adrenal cortex, the zona glomerulosa, produces the potent mineralcorticoid aldosterone. The enzymatic difference between the zona glomerulosa and the zona fasciculata is the absence of CYP17 from zona glomerulosa, which additionally has the ability to catalyze the 18-oxidation of corticosterone. In zona reticularis, androstenedione is converted into testosterone or estrone by 17-ketosteroid reductase (17ßHSD) and 19-hydroxylase (CYP19), respectively, which is converted into estradiol. Cortisol is produced in greater amounts compared to corticosterone in man and represents approximately $80 \%$ of the glucocorticoids production. In addition, androgens produced by the cortical cells,

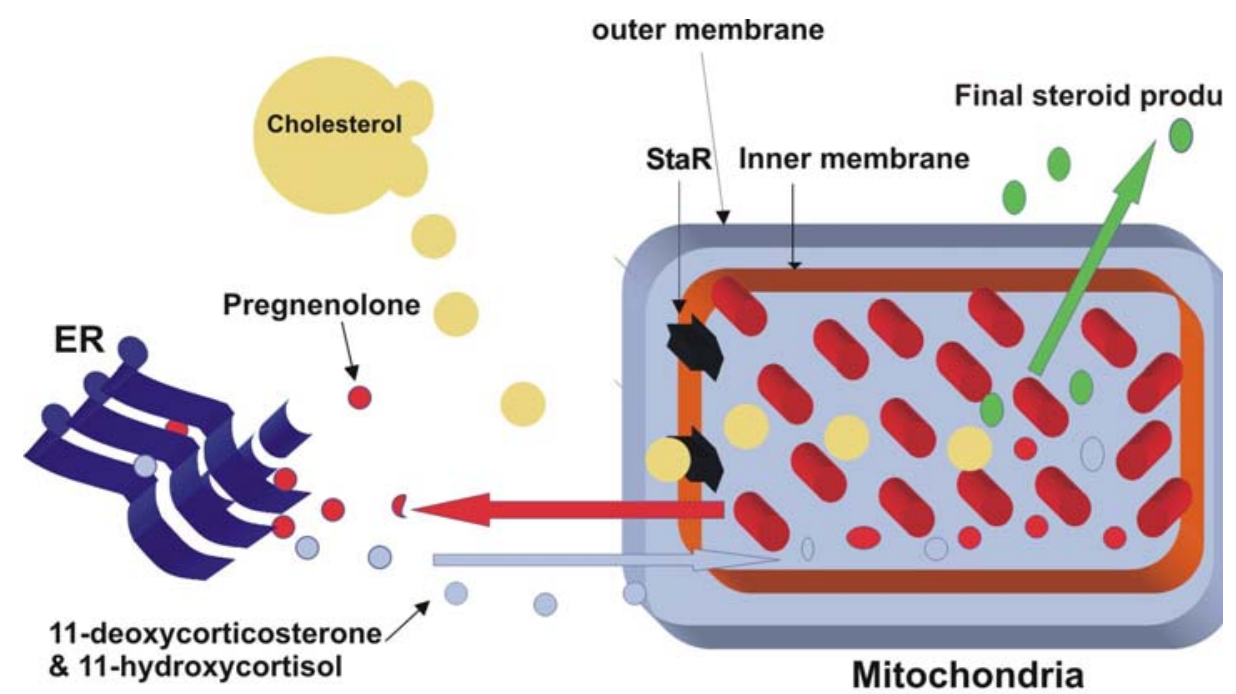

Figure 1.2 Shuttling of intermediate products of steroid biosynthesis. The intermediate products of steroid biosynthesis are shuttled between endoplasmic reticulum (ES) and mitochondria. The cholesterol is converted into pregnenolone in the mitochondria, which then shift to ES. The 11-deoxycorticosterone and 11-hydroxycortisol enter the mitochondria after production in ES for further modification. The final cortisol is produced inside the mitochondria. Modified from web tutorial. (StAR = steroidogenic acute regulatory protein) 
especially in the zona reticularis. The androgens produced by the zona reticularis can be metabolized to testosterone or estrogens by the cortical cells themselves or by metabolic pathways in other organs, such as the gonads. Species that produce predominantly corticosterone (such as rats and mice) have little sex hormone production by the adrenal glands (Harvey 1996; Kroboth et al. 1999; Rainey et al. 2002; Wilson et al. 1992).

\subsubsection{Regulation of adrenal glands}

Endogenous glucocorticoids are secreted by the adrenal gland under tight control of the brain. The neuroendocrine system that regulates this secretion is known as the Hypothalamo-Pituitary-Adrenal axis or HPA-axis. This system provides the link between the perception of physical and psychological stress and the regulation of key homeostatic mechanisms in brain and periphery. Neural stimuli from the brain, as in the response to stress, cause the release of corticotrophin-releasing hormone $(\mathrm{CRH})$, vasopressin (AVP) and other agents from hypothalamic neurons into the hypothalamic-hypophyseal portal blood. These hormones synergistically stimulate systemic adrenocorticotrophin hormone (ACTH) secretion, which, in turn, stimulates the adrenal cortex to secrete glucocorticoids. ACTH is a 39 amino acid long peptide hormone released by the anterior pituitary gland and has several distinct effects on the adrenal gland, which are evident at different time intervals after stimulation. $\mathrm{ACTH}$ binds to the high-affinity receptors on the plasma membrane of adrenocortical cells. This activates the adenylate cyclase via $\mathrm{G}$-protein $\left(\mathrm{G}_{\mathrm{s}}\right)$, and results in an increase in the intracellular cAMP which in turn activates protein kinase A. Protein kinase A phosphorylates the cholesteryl ester hydrolase, increasing its activity and conversion of cholesteryl esters to free cholesterol, the initial and rate limiting step in the cortisol production. The cholesterol is then converted to pregnenolone. In addition increase in the rate of blood flow through the adrenal gland and an increase in the rate of steroid secretion is also part of acute effects of ACTH. The chronic effects of ACTH on steroid biosynthesis include an increase the synthesis of all enzymes of steroidogenic pathway and more general actions on adrenocortical cell protein, RNA and DNA synthesis for the cell growth (Simpson et al. 1983; Simpson et al. 1988). To maintain the normal function and structure of adrenal gland, a certain level of ACTH secretion is always required. The effect of ACTH on the production of cortisol is particularly important, with the result that a classic feedback loop is prominent in regulating the circulating levels of $\mathrm{CRH}, \mathrm{ACTH}$, and cortisol.

Mineralcorticoid secretion from the zona glomerulosa is stimulated by an entirely different mechanism. Angiotensin II and angiotensin III, derived from the action of the 
kidney protease renin on liver-derived angiotensinogen, stimulate zona glomerulosa cells by binding a plasma membrane receptor coupled to phospholipase $\mathrm{C}$. This leads to the activation of protein kinase $\mathrm{C}$ and elevated intracellular $\mathrm{Ca}^{2+}$ levels. These events lead to an increased CYP11A1 activity and increased production of aldosterone. In the kidney, aldosterone regulates sodium retention and potassium secretion by stimulating gene expression of the $\mathrm{Na}^{+} / \mathrm{K}^{+}$-ATPase and the epithelial $\mathrm{Na}^{+}$ channels responsible for the re-accumulation of sodium from the urine. The interplay between renin from the kidney and plasma angiotensinogen is important in regulating plasma aldosterone levels, sodium and potassium levels, and ultimately blood pressure (Harvey 1996).

Cortisol is bound in the circulation to an a-globulin called corticosteroid-binding globulin (CBG). There is also a minor degree of binding to albumin. Corticosterone is also bound, but to a lesser degree. The half life of cortisol in the circulation is longer (60-90 minutes) than that of corticosterone (50 minutes). Bound steroids appear to be physiologically inactive. The bound cortisol function acts as a circulating reservoir of hormone that contains a continues supply of free cortisol available to the tissues.

\subsubsection{Actions of adrenal steroids}

Virtually every cell in the body is sensitive to actions of steroid hormones. Because so many physiological processes are affected, it is difficult to formulate a unifying definition of glucocorticoids action. Presumably all physiological actions of glucocorticoids are mediated by binding to specific soluble intracellular receptor proteins. Once the steroid is bound, the hormone-receptor complex acquires the capacity to bind to the DNA. These glucocoticoid-receptor complexes regulate the gene expression by interacting with specific regulatory DNA sequences, termed glucocorticoid responsive elements (GREs), which are usually located near the promoter region of target genes (Beato 1989). Glucocorticoids act on a wide range of physiological functions, including those involved in energy balance and metabolism, immunity, circadian rhythmicity, cardiovascular regulation, cognitive processing, behavioural adaptation and mood (Fink 2000). Glucocorticoids have an antagonistic action on insulin in intermediary metabolism as they increase hepatic glycogenesis by activating glycogen synthase and inactivating glycogen phosphorylase (Stalmans et al. 1979). They also increase hepatic gluconeogenesis by activation of glucose-6phosphatase and pyruvate kinase and mobilisation of glucogenic substrates from peripheral tissues (Baxter et al. 1979). High glucocorticoid levels in the serum have prominent anti-inflammatory and immunosuppressive action, and thus glucocorticoids have an important role in the modulation and suppression of the acute stress 
response and have pharmacological uses. However, their role in the normal modulation of immune processes is unclear (Gardner et al. 1986). The actions of synthetic glucocorticoids are generally more potent than those of naturally occurring glucocorticoids. For this reason and because they are often devoid of mineralcorticoid (salt-retaining) actions, they are commonly used as antiinflammatory and immunosuppressive drugs. A major target of glucocorticoids is the brain (Belanoff et al. 2001). Their effects on the brain range from feedback inhibition of their own secretion (Dallman et al. 1987), and modification of neuronal integrity and function to modulation of memory and learning processes and behavioural adaptation to stress (McEwen 1999).

\subsection{HUMAN ADRENOCORTICAL CELLS}

Cultures of the adrenal cortex offer useful models to study the biology of the various steroids pathways, including their hormonal control, interrelationships, and secretion. Primary cultures of normal or neoplastic human adrenal cells are short-lived and laborious. In addition, patient-to-patient variation in the pathophysiology and the treatment history make it difficult to conduct long and comparable investigations. The availability of a cell line which expresses the compartment of adrenal steroidogenic enzymes would clearly help in the determination of the mechanism leading to the production of steroid hormones by each of the three zones of the adrenal cortex, as well as providing a model system for the definition of the pathophysiologic conditions associated with the adrenal cortex. However, the list of permanent cell lines established from human adrenocortical adenocarcinomas is remarkably short. Five putative human cell lines have been reported so far. The SW-13 cell line was established by Leibovit (Leibovit et al. 1973) from an undifferentiated "small cell" carcinoma of adrenal cortex. It is not known to secret any steroid product. An estrogen secreting cell line was established by Fang (Fang 1977). There was only one further citation to this cell line, by Furuhachi and Fang (Furuhashi et al. 1980). In 1987, Moffet described, an adrenal tumor line that secreted renin and angiotensinogen (Moffett 1987). Recently, a new cell line has been derived from male adrenal carcinoma, but no steroid production by this cell line has been reported (Ueno et al. 2001). Thus, none of the three human lines mentioned above secrete any of the major steroid products of the normal adrenal cortex.

Gazdar and colleagues (Gazdar et al. 1990) established the NCl-H295 cell line from an invasive primary adrenocortical carcinoma from a patient. Case history: A 48year-old black woman from the Bahamas was evaluated in October 1980 for weight 
loss, edema, diarrhea, and recent cessation of menses. Her serum cortisol was 11.9 $\mathrm{ug} / \mathrm{dl}$, and her 24-h urine excretion levels of cortisol, and aldosterone, were greatly elevated, while her 17-hydrooxycorticosterone levels were near the upper limit of normal, but could not be suppressed with dexamethasone. A computer-assisted tomography scan revealed a large adrenal mass. A $14 \times 13 \times 11-\mathrm{cm}$ right adrenal mass was removed surgically. The tumor had the histological appearances typical of a malignant adrenocortical carcinoma, including abundant cytoplasm and large oval to round nuclei with prominent nucleoli (Gazdar et al. 1990). Because of fibroblast growth, a population of tumor cells, which grew as a suspension, was used to establish the $\mathrm{NCl}-\mathrm{H} 295$ cell line. The initial description and analysis of the steroidogenic properties of the $\mathrm{NCl}-\mathrm{H} 295$ cells were performed after the cells had been in culture for 7-10 years. More than 30 steroids were detected in the culture medium from $\mathrm{NCl}-\mathrm{H} 295$ cells, of which about 20 were identified. Depending on the culture condition and nature of stimulation with $\mathrm{ACTH}$, forskolin, dbcAMP and angiotensin II, the major steroid produced by the cells were glucocorticoid, mineralcorticoids, and $\mathrm{C} 19$ steroids.

The $\mathrm{NCl}-\mathrm{H} 295 \mathrm{R}$ cell line was derived from the $\mathrm{NCl}-\mathrm{H} 295$ pluripotent adrenocortical carcinoma cell line. The original cells were adapted to a culture medium, which decreased the population doubling time from 5 days to 2 days. While the original cells grew in suspension, the adapted cells were selected to grow in a monolayer. For this purpose, selection of an $\mathrm{NCl}-\mathrm{H} 295$ cell strain that retained attachment during cultures was accomplished by changing medium routinely over a 3-month period and maintaining only the cells that were attached to the culture dishes. This cell line retains the ability to produce steroid hormones after treatment with $\mathrm{ACTH}$, forskolin, dbcAMP and angiotensin II (Rainey et al. 1993; Rainey et al. 1994). The treatment with angiotensin II or potassium ion $\left(\mathrm{K}^{+}\right)$resulted in a concentration-dependent increase in aldosterone production. $\mathrm{NCl}-\mathrm{H} 295 \mathrm{R}$ cells have a low response to $\mathrm{ACTH}$, which is due to the low expression of ACTH receptors (Mountjoy et al. 1994). Treatment of $\mathrm{NCl}-\mathrm{H} 295 \mathrm{R}$ cells with forskolin or dbcAMP stimulated cortisol production to a greater degree than did ACTH (Rainey et al. 1993). After forskolin treatment, cortisol became the major steroid product, representing $70 \%$ of the total steroid products (Rainey et al. 1994). This demonstrates an important property of $\mathrm{NCl}-\mathrm{H} 295 \mathrm{R}$ cell line that these cells can be manipulated by forskolin treatment to increase the production of cortisol and are thus a representative model of zona fasciculata cells. 


\subsection{RELEASE OF STERIODS THROUGH THE PLASMA MEMBRANE}

The steroid biosynthesis, the regulation of steroid release and their physiological effects on the function in the body have been topics of intensive research since the first description of adrenals by Bartholomeo Eustachius in Tabulae Anatomicae, which was later edited and published (Eustachius 1774). In the recent years, there have been numerous additions to the knowledge of different biosynthetic pathways and their action on their target organs and cells. In contrast, the release of steroids from the steroid synthesizing cells into the blood and their entry into the target cells is poorly understood. It has long been assumed that the release occurs via simple diffusion or exocytosis, based on the lipophilic structure of steroid hormones. The idea of exocytosis or any relevant storage of cortisol has never been supported by direct morphological evidence (Bassett et al. 1980; Gemmell et al. 1977). However, in vitro studies have demonstrated retention of steroids against a concentration gradient at the plasma membrane (Inaba et al. 1974; Whitehouse et al. 1971).

The transporter-mediated uptake of glucocorticoids was first demonstrated by Rao (Rao et al. 1976). The uptake of cortisol into isolated liver cells was temperature dependent, showed saturation kinetics, was inhibited by cortisone and corticosterone, and was significantly decreased by metabolic inhibitors and sulfhydryl reagents. The uptake was independent of sodium and showed no effect by ouabain. The uptake into the liver cells from the external media was a rapid process, and showed protein mediated characteristics. As the specific glucocorticoids binding proteins are localised in the cytoplasm, their involvement in uptake of cortisol was not suggested. In conclusion the transport of cortisol into the liver cells seemed to be in part a carrier-mediated action (Rao et al. 1976). Using the stop-flow peritubular capillary microperfusion method, Ullrich and co-workers (Ullrich et al. 1991) described the inhibition of contraluminal transport of radiolabeled $p$-aminohippurate (PAH) in the proximal tubule of the rat kidney by cortisol. In these experiments the basolateral uptake of PAH and of labeled cortisol into proximal tubule cells was inhibited by probenecid. These studies indicated the involvement of transporter proteins in the translocation of glucocorticoids through the plasma membrane.

Recent studies showed the inhibition of cortisol release from primary cultures of bovine adrenocortical cells by probenecid. Further investigations on bovine adrenocortical cells demonstrated an uptake of radioactively labeled $\mathrm{PAH}$, which was inhibited by probenecid. The uptake of organic anions (i.e. PAH) into the cells as well as the cortisol release from the cells was stimulated by ACTH (Steffgen et al. 1999). 
These data indicated the possible involvement of organic anion transporters in cortisol release. Investigations on the molecular level of rat adrenals revealed the expression of organic anion transporter 1 (OAT1). In-situ hybridizations and immunohistochemical analyses localized rat OAT1 to the zona fasciculata of the adrenal cortex, where cortisol synthesis and release take place. Importantly, OAT1 mRNA expression was strongly increased by treatment of rats with $\mathrm{ACTH}$ in vivo (Beery et al. 2003). All these evidences emphasize the possible involvement of a transport mechanism in steroid hormone release from adrenocortical cells.

\subsubsection{Organic anion transporter (OAT) family}

One of the possible candidates for glucocorticoid export from adrenocortical cells is the organic anion transporter. Organic anion transporters (OAT) perform an important task in the renal secretion of a wide range of organic anions, such as endogenous metabolic waste products and exogenous potentially toxic compounds, especially drugs such as loop diuretics, non-steroidal anti-inflammatory drugs, and ß-lactam antibiotics. The secretion of these permanently negatively charged organic anions occurs in the renal proximal tubule. These transporters are conserved through evolution from Caenorhabditis elegans to mammals (Burckhardt et al. 2003).

The topological organization of OAT1 proteins within the membrane is unknown, however secondary structure studies predict them to span the membrane twelve times and to have two large hydrophilic loops between trans-membrane domains one and two and between trans-membrane domains six and seven. Both $\mathrm{C}$ and $\mathrm{N}$-termini located in the cytosol (Burckhardt et al. 2000b).

Transport of organic anions through OAT1 and OAT3 into the proximal tubule cells at the basolateral membrane is a tertiary active exchange against $\alpha$-ketoglutarate. The intracellular $\alpha$-ketoglutarate level is maintained by metabolism and by transport into the cells across the basolateral as well as the luminal membrane, mediated by sodium-dicarboxylate co-transporters. The inwardly directed gradient for sodium is maintained by the primary active, basolaterally located $\mathrm{Na}^{+} / \mathrm{K}^{+} \mathrm{ATPase}$ (Burckhardt et al. 2000a; Burckhardt et al. 2001b).

Meanwhile more than four isoforms of the OAT family (OAT1, OAT2, OAT3 and OAT4) are known in their molecular structure and are functionally characterized. Since 1997 several groups cloned OAT1 orthologs from different species like the rat, Winter flounder, human, rabbit and pig (Bahn et al. 2002a; Hagos et al. 2002; Sekine et al. 1997; Wolff et al. 1997). The human OAT1 ortholog was cloned in 1998/99 (Hosoyamada et al. 1999; Reid et al. 1998) and functionally characterized. The model substrate of OAT1 is PAH which exhibits a high affinity with $\mathrm{K}_{m}$ values in 
the range of 4 to $20 \mu \mathrm{M}$. An interaction of human OAT1 with cortisol has not yet been tested directly.

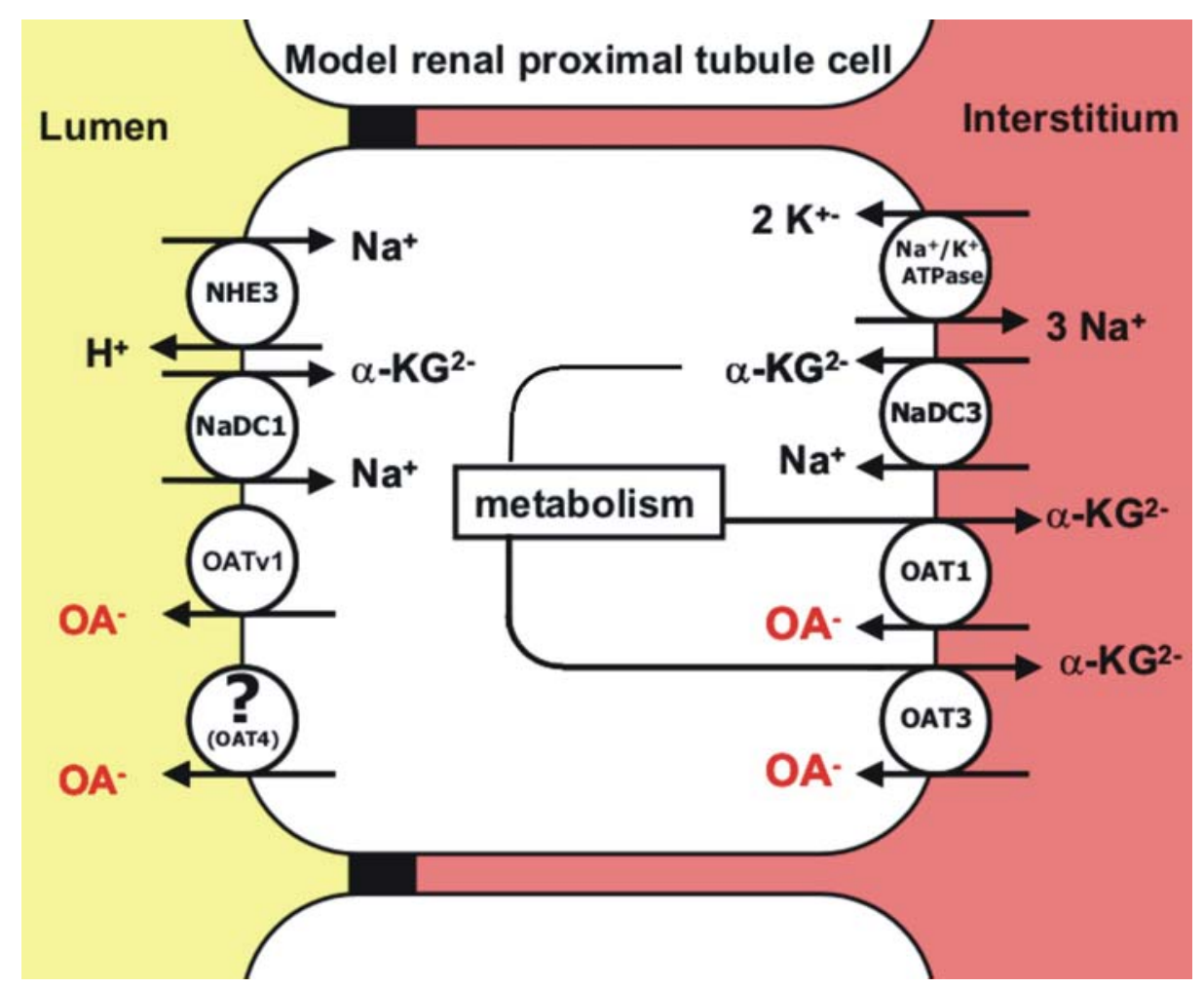

Figure 1.2 Secretion of organic anions in a model renal proximal tubule cell. The organic anions $\left(\mathrm{OA}^{-}\right)$are taken up from the interstitium/blood into proximal tubule cells. The secretory pathway for organic anions through OAT1 and OAT3 exchange an extracellular $\mathrm{OA}^{-}$against an intracellular $\alpha$-ketoglutarate $\left(\alpha-\mathrm{KG}^{2-}\right)$. The $\alpha$-ketoglutarate released by OAT1 and OAT3 is pumped back into the cell by NaDC-3, and the three $\mathrm{Na}^{+}$ ions co-transported with $\alpha$-ketoglutarate are removed by the $\mathrm{Na}^{+}, \mathrm{K}^{+}$-ATPase. Additionally the intracellular pool of $\alpha$-ketoglutarate is maintained by its generation through metabolism. Several transporters for organic anions have been identified on the luminal membrane such as the urate/anion exchanger (URAT1), multidrug resistance protein 2 (MRP-2), sodium-phosphate transporter (NPT), and OAT4.

Another member of OAT family is OAT2, which was initially cloned as a novel liver transporter (NLT) (Sekine et al. 1998b; Simonson et al. 1994) and transports aketoglutarate, prostaglandins, salicylate, and PAH (Burckhardt et al. 2003). As with OAT1, the interaction of OAT2 with glucocorticoids was not tested. Several orthologs of OAT3 were cloned and functionally characterized (Cha et al. 2001; Hasegawa et al. 2002; Race et al. 1999). The transport mechanism of OAT3 is similar to that of OAT1, as it exchanges organic anions against dicarboxylates like glutarate and $\alpha-$ ketoglutarate (Bakhiya et al. 2003; Sweet et al. 2002). Immunohistochemical analyses revealed the localization of hOAT1 and hOAT3 at the basolateral 
membrane of proximal tubule cells. Real-time PCR data of human kidney cortex showed a two fold higher expression of hOAT3 compared to hOAT1 and a more than tenfold higher expression than that of hOAT2 and hOAT4 (Motohashi et al. 2002). The expression analysis of rat kidney showed a higher expression of rOAT1 than of rOAT3, while, the hOAT3 expression is stronger than hOAT1 in human kidney (Bossuyt et al. 1996b). The human OAT3 has a high affinity for estrone sulfate (ES), dehydroepiandosterone sulfate (DHEAS), and 17ß-estradiol-17ßD-glucuronide, but exhibits low affinity for PAH (Cha et al. 2001; Race et al. 1999; Sugiyama et al. 2001). Corticosterone inhibited estrone sulfate transport by hOAT3 (Cha et al. 2001). These facts suggest the interaction of OAT3 in transport of sulfated and glucuronidated steroid hormones and possibly in translocation of glucocorticoids into the cells. The fourth member of organic anion transporter family, OAT4, was cloned from a human kidney cDNA library and was evident from placenta too (Cha et al. 2000). Up to now there is no comparable ortholog for hOAT4 from other species, and it seems that OAT4 represents a human-specific member of the organic anion transporter family. Human OAT4 shares substrate specificity with hOAT3. It has a very high affinity for DHEAS and estrone sulfate with $K_{m}$ of 0.6 and $1.0 \mu \mathrm{M}$, respectively, but does not show any affinity for glucuronic acid-conjugated steroids (e.g. $\beta$-estradiol-3 $\beta$-D-glucuronide). The estrone sulfate uptake by OAT4 was inhibited by corticosterone (Cha et al. 2000), pointing to a possible interaction of hOAT4 with glucocorticoid translocation.

\subsubsection{Organic anion transporter polypeptide (OATP) family}

Another possible candidate for the steroid release from human adrenocortical cell are organic anion transporter polypeptides (OATP). OATPs are selectively expressed in rodent and human livers, where they are involved in the hepatic clearance of albumin-bound compounds from portal blood plasma (Meier et al. 2002). OATPs show multiple tissues expression including the blood-brain barrier (BBB), choroid plexus, lung, heart, intestine, kidney, placenta and testis (Tamai et al. 2000). A large number of members of the OATP family have not been characterized in detail on the functional, structural and genomic levels. However, initial studies with individual OATPs indicate that many members of this transporter family represent polyspecific organic anion carriers with partially overlapping substrate preferences for a wide range of amphipathic organic solutes including bile salts, organic dyes, steroid conjugates, thyroid hormones, anionic oligopeptides, numerous drugs and other xenobiotic compounds (Hagenbuch et al. 2003; Kullak-Ublick et al. 2000; KullakUblick et al. 2001; Meier et al. 1997). The hydropathy analysis showed that all 
OATPs have 12 transmembrane (TM) domains, which have yet to be proven by experimental evidence (Jacquemin et al. 1994).

The first human OATP cloned from human liver was OATP-A (Kullak-Ublick et al. 1995). OATP-A protein is expressed at the blood-brain barrier along the border of brain microvessels and capillary endothelial cells. OATP-A mRNA was detected in brain, lung, liver, kidney, and testis (Kullak-Ublick et al. 2001). As compared to other human OATPs, OATP-A exhibits broad substrate specificity and transports bile acids, bromosulfophthalein (BSP), steroid hormone conjugates, thyroid hormones, oligopeptides, ouabain, and amphipathic organic cations. Functional studies with OATP-A showed that it does not transport cortisol (Bossuyt et al. 1996b). Another member of OATP family, OATP-B, was isolated from human brain. The mRNA for OATP-B showed broad tissue distribution: liver, spleen, placenta, lung, kidney, heart, ovary, small intestine, and brain (Kullak-Ublick et al. 2001). The functional characterization showed that OATP-B mediates high affinity uptake of BSP and also transports estrone-3-sulfate and DHEAS, but not bile acids.

OATP-C and OATP-8 were cloned from human liver. OATP-C protein is expressed at the basolateral domain of human hepatocytes. The substrate specificity of OATP-C includes taurocholate, bilirubin, BSP, steroid hormone conjugates, thyroid hormones, prostanoids, oligopeptides, and the drugs benzylpenicillin and pravastatin (Abe et al. 1999; Hsiang et al. 1999; Konig et al. 2000a). OATP8 was also cloned from liver and its protein was localized to the basolateral domain of human hepatocytes. Functionally OATP8 transports BSP, steroid hormone conjugates, thyroid hormones (Konig et al. 2000a; Konig et al. 2000b). The OATP-D and OATP-E were cloned from human kidney and showed no homology with other members of OATP family. The OATP-D transports estrone-3-sulfate, prostaglandin $E_{2}$ and benzylpenicillin, and OATP-E transports in addition estradiol-17ß-glucuronide (Tamai et al. 2000). Only OATP-A has been tested for direct cortisol transport, which did not show any transport, while other members of OATP family members have not been tested for cortisol translocation (Bossuyt et al. 1996b; van Montfoort et al. 2003).

\subsubsection{P-glycoprotein (Pgp) family}

Another group of broad substrate specificity transporters is the P-glycoprotein family (Permeability-glycoprotein). P-glycoprotein (Pgp) plays an important role in multidrug resistance (MDR). The multidrug resistantce $P$-glycoprotein belongs to the subfamily $B$ of the adenosine triphosphate (ATP) binding cassette (ABC) superfamily of transporter proteins. Extensive studies have identified three classes of mammalian Pgps. Only two classes, class I and III, convey the MDR phenotype. Of the two 
human genes, primarily the MDR1 (Chin et al. 1989) confers drug resistance (Ueda et al. 1987). P-glycoprotein acts as an energy-dependent efflux pump that exports anticancer agents out of the cell, lowering their intracellular concentration to sublethal levels, and is considered to be important in multidrug resistance of human tumors (Gottesman et al. 1988). P-glycoprotein is expressed in normal human tissues and is found on the luminal surface of transporting epithelia of the kidney proximal tubule, small intestine, colon, and liver biliary hepatocytes and in capillary endothelial cells of the brain and testis as well as in the adrenal cortex (Thiebaut et al. 1987; Thiebaut et al. 1989). The location of P-glycoprotein expression suggests that one of the physiological roles of P-glycoprotein is the secretion of metabolites and natural toxic substances into bile and urine and directly into the lumen of the gastrointestinal tract. It is important to identify the physiological substrates to predict the side effects that may arise from preventing the function of P-glycoprotein in chemotherapy, but no physiological substrates for P-glycoprotein to transport have been identified. Many reports on the cortisol interaction with MDR1 have been published (Farrell et al. 2000; Farrell et al. 2002; Karssen et al. 2001). Kalken and co-worker showed that the steroid hormones cortisol, testosterone, and progestrone cause an immediate, dose dependent increase of daunorubicin accumulation in Pgp overexpressing cells (Vankalken et al. 1993). These results showed the importance of MDR1 as a possible candidate of cortisol release from adrenal cells.

\subsection{THE AIMS OF THE WORK}

The present study was designed to address the question whether transporter proteins mediate cortisol release from human adrenocortical cells. In particular, the role of organic anion transporters (OAT), in the endocrine function of the human adrenal cell line, $\mathrm{NCl}-\mathrm{H} 295 \mathrm{R}$, should be studied, because previous reports on bovine and rat adrenal cells suggested that OAT1 is involved in cortisol release. 


\section{MATERIALS}

\section{$2.1 \quad$ CHEMICALS}

All chemicals used in this study were obtained from Amersham (Freiburg, Germany), Sigma and Fluka (Deisenhofen, Germany), Merck (Haar, Germany), Applichem (Darmstadt, Germany), Serva (Heidelberg, Germany), Roth (Karlsruhe, Germany) or BioRad (München, Germany), if not stated otherwise in the text.

\section{$2.2 \quad$ RADIOCHEMICALS}

Uptake experiments were conducted using the following radiolabeled substances from NEN Life Science (Boston, MA, USA) and Amersham Biosciences (Freiburg, Germany).

(1) para-aminohippuric acid, (p-aminohippuric acid, p-[glycyl-2- $\left.{ }^{3} \mathrm{H}\right] ; \quad\left[{ }^{3} \mathrm{H}\right] \mathrm{PAH}$; specific activity: $3.97 \mathrm{Ci} / \mathrm{mmol})$, (NEN).

(2) Dehydroepiandrosterone sulfate, (dehydroepiandrosterone sulfate, sodium salt $\left[1,2,6,7-\left[{ }^{3} \mathrm{H}\right] \mathrm{DHEA}-\right.$ sulfate$\left.(\mathrm{N})\right]-$; $\left[{ }^{3} \mathrm{H}\right] \mathrm{DHEA}$ sulfate; specific activity: 74.0 $\mathrm{Ci} / \mathrm{mmol}),(\mathrm{NEN})$.

(3) Estrone sulfate, (estrone sulfate, ammonium salt, $\left[6,7-{ }^{3} \mathrm{H}(\mathrm{N})\right] ;\left[{ }^{3} \mathrm{H}\right]$ estrone sulfate; specific activity: $43.5 \mathrm{Ci} / \mathrm{mmol}),(\mathrm{NEN})$.

(4) Cortisol, ([1,2,6,7- ${ }^{3} \mathrm{H}$ cortisol], toluene : ethanol $9: 1$ solution); $\left[{ }^{3} \mathrm{H}\right]$ cortisol; specific activity: $64.0 \mathrm{Ci} / \mathrm{mmol}$, (Amersham).

\subsection{OLIGONUCLEOTIDES}

General PCR reactions for screening and sequencing of clones were carried out with sequence-specific primers from MWG Biotech AG (Ebersberg, Germany). cDNA was constructed using Oligo(dT) ${ }_{12-18}$ primer (Invitrogen, Karlsruhe Germany). All primers used are listed below. 
Oligonucleotide primer sequences used to amplify members of human OAT family

\begin{tabular}{lll}
\hline Target & Nucleotide sequence (5-3) & Accession No \\
\hline $\begin{array}{l}\text { hOAT1_933For } \\
\text { hOAT1_1434Rev }\end{array}$ & $\begin{array}{l}\text { GGGCACCTTGATTGGCTATGTC } \\
\text { GATGACAAGGAAGCCCACAAGC }\end{array}$ & AB009697 \\
hOAT2_835For20 & TCTGCACGCTGGCTTCTGAC & AF210455 \\
hOAT2_1386Rev22 & TGTCTGTCTGAGCACCGTAGGG & \\
hOAT3_871For & CTTCCTATCATCCTGGTGGAC & AB042505 \\
hOAT3_1419Rev & TAGAGGAAGAGGCAGCTGAAG & \\
hOAT4_130For & CATGGCGTTCTCGAAGCTC & AL514126 \\
hOAT4_722Rev & CGCAGTAGATGACGAATGTTG & \\
GAPDH_334For & TCACCATCTTCCAGGAGCG & M33197 \\
GAPDH_905Rev & CTGCTTCACCACCTTCTTGA &
\end{tabular}

Table 2.1 List of oligonucleotide primer sequences used to amplify members of human OAT family (OAT1, OAT2, OAT3, OAT4) and GAPDH from NCl-H295R cells, human normal adrenal and tumor tissues. Numbers in the primer name represents the position of the start of the sequence of primer from the respective clone. The clones identity is cited in the last column ( $h=$ human, For $=$ forward, and Rev $=$ reverse $)$

Oligonucleotide primer sequences used to amplify members of OATP family

\begin{tabular}{lll}
\hline Target & Nucleotide sequence (5-3) & Accession No \\
\hline $\begin{array}{l}\text { hOATP-A_831For } \\
\text { hOATP-A_1413Rev }\end{array}$ & $\begin{array}{l}\text { CAGGAGTTAACGTGCTCACTG } \\
\text { GATGGACAGTTGCAATCCAC }\end{array}$ & XM_050036 \\
$\begin{array}{l}\text { hOATP-B_382For } \\
\text { hOATP-B_956Rev }\end{array}$ & $\begin{array}{l}\text { CCTAAAGAGCTCCATCTCCAC } \\
\text { CTGGCATCTGGTTAATGTCC }\end{array}$ & AB026256 \\
hOATP-C_662For & $\begin{array}{l}\text { TCATTGGCTTTACCCTGGGATC } \\
\text { hOATP-C_1224Rev }\end{array}$ & NM_006446 \\
$\begin{array}{l}\text { GOATP-E_524For } \\
\text { hOATP-E_1073Rev }\end{array}$ & $\begin{array}{l}\text { ATCGCCAGCTCCTACGACATTG } \\
\text { GGGAACGGCGGTGAAGAAAG }\end{array}$ & AB031051
\end{tabular}

Table 2.2 List of oligonucleotide primer sequences used to amplify members of human OATP family (OATP-A, OATP-B, OATP-C, OATP-E) from NCl-H295R cells, human normal adrenal and tumor tissues. Numbers in the primer name represent the position of start of the sequence of primer from the respective clone. The clone's identity is cited in the last column ( $h=$ human, For $=$ forward, and Rev $=$ reverse $)$. 
Oligonucleotide primer sequences used to amplify MDR1

\begin{tabular}{lll}
\hline Target & Nucleotide sequence (5-3) & Accession No \\
\hline MDR1_302For20 & CTCTTCCAAGCTCAAAGAAG & M14758 \\
MDR1_825Rev22 & GAAACCTGAATGTAAGCAGCAA &
\end{tabular}

Table 2.3 Oligonucleotide primer sequences used to amplify MDR1 NCI-H295R cells, human normal adrenal and tumor tissues. Numbers in the primer name represent the position of start of the sequence of primer from the respective clone. The clone's identity is cited in the last column ( $h=$ human, Far $=$ forward, and Rev = reverse).

Oligonucleotide primer sequences used to amplify members of cytochrome P450 enzymes

\begin{tabular}{lll}
\hline Target & Nucleotide sequence (5-3) & Accession No \\
\hline $\begin{array}{l}\text { CYP11B1_977For22 } \\
\text { CYP11B1_1560Rev20 }\end{array}$ & $\begin{array}{l}\text { CACCCAGTGGGGAATGGAGGCC } \\
\text { CCCGTTTCCCTGAGTCCTC }\end{array}$ & M32878.1 \\
CYP11B2_970For22 & CACCCAGTGGGGAATGGAGGCC & M32880.1 \\
CYP11B2_1573Rev22 & GGATCCCCACACAGGTAACTGC & \\
StAR_594For20 & CCTGCAGAAGATCGGAAAAG & U17280.1 \\
StAR_1097Rev20 & CATCCCACTGTCACCAGATG & \\
CYP11A1_325For20 & GCAACGTGGAGTCGGTTTAT & M14565.1 \\
CYP11A1_845Rev20 & CACATGGTCCTTCCAGGTCT & \\
3BHSD_646For20 & CGGCTAATGGGTGGAATCTA & NM_000198 \\
3BHSD_1155Rev20 & GATCTCGCTGAGCCTTCTTG & \\
CYP17_454For20 & GCGATCAGAAGCTGGAGAAG & M14564 \\
CYP17_973Rev19 & CCACAGAGGTGGTGGTCTC & \\
CYP21A2_339For20 & CCAAGAGGACCATTGAGGAA & NM_000500 \\
CYP21A2_913Rev20 & CACCCCTTGGAGCATGTAGT &
\end{tabular}

Table 2.4 List of oligonucleotide primer sequences used to amplify members of cytochrome P450 enzymes (StaR, CYP11A1, CYP17, 33HSD, CYP21A2, CYP11B1 and CYP11B2) from NCl-H295R cells, human normal adrenal and tumor tissues. Numbers in the primer name represent the position of start of the sequence of primer from the respective clone. The clone's identity is cited in the last column (StaR = steroidogenic-acute-regulatory protein, CYP11A1 = side-chain cleavage enzyme desmolase, $\mathrm{CYP} 17=17 \alpha-$ hydroxylase $/ 17,20$ lyase, $3 \beta \mathrm{HSD}=3 \beta$-hydroxysteroid dehydrogenase, $\mathrm{CYP} 21 \mathrm{~A} 2=21-$ hydroxylase, $\mathrm{CYP} 11 \mathrm{~B} 1=$ steroid $11 \beta$-hydroxylase, $\mathrm{CYP} 11 \mathrm{~B} 2=11 \beta$-hydroxylase aldosterone synthase, $\mathrm{h}=$ human, For $=$ forward, and Rev = reverse). 


\subsection{CELL LINES}

NCl-H295R: human adrenocortical carcinoma cell line, ATCC (Manessas, VA, USA) COS-7: origin African green monkey kidney, DSMZ-GmbH (Braunschweig, Germany).

T-REx ${ }^{\text {TM }}$-HEK 293: Human embryonic kidney, (Graham et al. 1977) Invitrogen Life technologies (Karlsruhe, Germany).

\subsection{CELL CULTURE MEDIA AND SUPPLEMENTS}

Dulbecco's modified Eagle's medium (DMEM), fetal calf serum, Dulbecco's modified Eagle's medium nutrient mixture F-12 HAM, Phosphate Buffered Saline (PBS), and Penicillin/Streptomycin $10000 \mathrm{U}$ were from Gibco/Invitrogen Life Technologies (Karlsruhe, Germany).

ITS ${ }^{\mathrm{TM}}$ Premix and Nu-Serum, BD GmbH (Heidelberg Germany).

\subsection{MISCELLANEOUS}

$35 \mathrm{~mm}, 100 \mathrm{~mm}, 145 \mathrm{~mm}$ culture Petri dishes, $25 \mathrm{~cm}^{2}$ flasks, $45 \mathrm{~cm}^{2}$ flasks and 75 $\mathrm{cm}^{2}$ flasks were from Falcon (Lincoln Park, NJ USA). Six-well, 24-well, 96 well culture plates, cryopreservation vials, and sterile filters $0.2 \mu \mathrm{m}$ were purchased from Nunc (Wiesbaden, Germany).

The SDS PAGE Standard Low Range was by BioRad GmbH (München, Germany), Rainbow RPN 800 High Range Protein Marker by Amersham (Freiburg, Germany), while $100 \mathrm{Bp}$ Standard DNA Marker was purchased from MBI-Fermentas (USA)

\section{$2.7 \quad$ BUFFERS}

Following buffers were mostly used. Other compositions are cited in the text

Membrane buffer $\quad \mathrm{NaCl} 150 \mathrm{mM}$, Tris/ $\mathrm{HCl} 50 \mathrm{mM} \mathrm{pH}$ 7.5, EDTA 5mM, PMSF 0.1 $\mathrm{mg} / \mathrm{ml}$, aprotinin $4 \mathrm{ng} / \mathrm{ml}$, leupeptin $4 \mathrm{ng} / \mathrm{ml}$

BBMV buffer $3 \mathrm{X} \quad 300 \mathrm{mM}$ mannitol, $5 \mathrm{mM}$ EGTA, $12 \mathrm{mM}$ Tris/HCl, $\mathrm{pH} 7.4$

Sample buffer $\quad 1 \%$ SDS, $12 \% \mathrm{v} / \mathrm{v}$ glycerol, $5 \% \beta$-mercaptoethanol, $30 \mathrm{mM}$ Tris/ $\mathrm{HCl}, \mathrm{pH} 6.8$

Electrophoreses $\quad 0.025 \mu \mathrm{M}$ Tris and $0.192 \mu \mathrm{M}$ glycine and $0.1 \%$ SDS, $\mathrm{pH} 8.3$

buffer

Blotting buffer $\quad 5 \%$ non-fat dry milk, $0.15 \mathrm{M} \mathrm{NaCl}, 1 \%$ Triton X-100, $20 \mathrm{mM}$ Tris/ $\mathrm{HCl}, \mathrm{pH} 7.4$ 
Reha buffer

Rehydration buffer

TBE buffer

TAE buffer

Oocyte Ringer solution (ORI)

Oocytes Barth's solution

Mammalian Ringer solution

DEPC-water
$7 \mathrm{M}$ urea, $2 \mathrm{M}$ thiourea, 4\% CHAPS, $10 \mathrm{mM}$ DTT, 2\% ampholyte 3-10 (w/v)

$7 \mathrm{M}$ urea, $2 \mathrm{M}$ thiourea, $0.5 \%$ CHAPS, $15 \mathrm{mM}$ DTT and $0.2 \%$ ampholyte (w/v)

$45 \mathrm{mM}$ Tris, $45 \mathrm{mM}$ borate, and $1 \mathrm{mM}$ EDTA

$0.04 \mathrm{M}$ Tris, $0.001 \mathrm{M}$ EDTA-Na ${ }_{2}$-salt and $0.02 \mathrm{M}$ acetic acid

$90 \mathrm{mM} \mathrm{NaCl}, 3 \mathrm{mM} \mathrm{KCl}, 2 \mathrm{mM} \mathrm{CaCl} 2,1 \mathrm{mM} \mathrm{MgCl}, 5 \mathrm{mM}$ HEPES/Tris, pH 7.6

$88 \mathrm{mM} \mathrm{NaCl}, 1 \mathrm{mM} \mathrm{KCl}, 0.3 \mathrm{mM} \mathrm{Ca}\left(\mathrm{NO}_{3}\right)_{2}, 0.41 \mathrm{mM} \mathrm{CaCl}$, $0.82 \mathrm{mM} \mathrm{MgSO}_{4}, 15 \mathrm{mM}$ HEPES, $10 \mathrm{mg} / \mathrm{l}$ gentamicin, $\mathrm{pH} 7.6$

$130 \mathrm{mM} \mathrm{NaCl}, 4 \mathrm{mM} \mathrm{KCl}, 1 \mathrm{mM} \mathrm{CaCl}_{2}, 1 \mathrm{mM} \mathrm{MgSO}$, $20 \mathrm{mM}$ HEPES, $1 \mathrm{mM} \mathrm{NaH}_{2} \mathrm{PO}_{4}$, and $18 \mathrm{mM}$ glucose, $\mathrm{pH} 7.4$

$0.1 \%$ diethylpyrocarbonate $(\mathrm{v} / \mathrm{v})$ into distilled water

\subsection{SCIENTIFIC SOFTWARES}

The following scientific software was used during the course of this study

\begin{tabular}{|c|c|c|}
\hline Program & Use & Reference \\
\hline Lablmage V 2.62 & densitomatric analysis & Kapelan GmbH, Halle, Germany \\
\hline One-Dscan V 1.0 & densitomatric analysis & Scanalytics, CSP Inc. CA, USA \\
\hline Sopt software & Immunostaining & Diagnostic Instru. MI, USA \\
\hline Chromas V 1.45 & sequence reading & Conor McCarthy \\
\hline $\begin{array}{l}\text { Gene Runner } \\
\text { V } 3.05\end{array}$ & primer design & Hastings Software Inc \\
\hline SigmaPlot V 8.0 & statistical analysis & Jandel Corporation LI, USA \\
\hline $\begin{array}{l}\text { Microsoft Excel } \\
2000\end{array}$ & statistical analysis & Microsoft Corporation, USA \\
\hline $\begin{array}{l}\text { Data Explorer } \\
\text { Voyager V } 5.0\end{array}$ & $\begin{array}{l}\text { MALDI-TOF data analysis } \\
\text { software }\end{array}$ & $\begin{array}{l}\text { Applied Biosystems, Laguna } \\
\text { Beach, USA }\end{array}$ \\
\hline $\begin{array}{l}\text { ProteinChip } \\
\text { Reader Software }\end{array}$ & $\begin{array}{l}\text { SELDI - TOF data analysis } \\
\text { software }\end{array}$ & Ciperegen Corporation, USA \\
\hline PDQuest V1.1 & 2-DE gel analysis & BioRad, München, Germany \\
\hline
\end{tabular}


Online sequence analysis servers

\begin{tabular}{|c|c|c|}
\hline Program & Use & Reference \\
\hline Blast & $\begin{array}{l}\text { finds similar database } \\
\text { sequences }\end{array}$ & http://www.ncbi.nlm.nih.gov/BLAST/ \\
\hline Entrez Pubmed & sequence retrieval & http://www.ncbi.nlm.nih.gov/entrez/ \\
\hline MAP & $\begin{array}{l}\text { multiple sequence } \\
\text { alignments }\end{array}$ & http://genome.cs.mtu.edu/map.html \\
\hline Primer 3 & Primer design & $\begin{array}{l}\text { http://www.broad.mit.edu/cgi- } \\
\text { bin/primer/primer3_www.cgi }\end{array}$ \\
\hline Moscot & $\begin{array}{l}\text { protein database } \\
\text { search }\end{array}$ & www.matrixscience.com \\
\hline
\end{tabular}

\subsection{EQUIPMENTS}

\begin{tabular}{|c|c|c|}
\hline Appliance & Model & Manufacturer \\
\hline Centrifuges & $\begin{array}{l}\text { Biofuge fresco } \\
5417 R \\
1394\end{array}$ & $\begin{array}{l}\text { Heraeus (Osterode, Germany) } \\
\text { Eppendorf (Hamburg, Germany) } \\
\text { Hettich (Stockholm, Sweden }\end{array}$ \\
\hline Ultra centrifuge & $\begin{array}{l}\text { OTD 65B Rotor TFT } \\
65.13\end{array}$ & Sorvall (Neutown, USA) \\
\hline Circulating water bath & RCB 300 & Hoefer (San Francisco, USA) \\
\hline Dissection microscope & Stemi 1000 & Zeiss (Jena, Germany) \\
\hline Gel Chambers & Mini, Medi and Maxi & $\begin{array}{l}\text { Amersham Biosciences (Freiburg, } \\
\text { Germany) }\end{array}$ \\
\hline Gel documentation & Gel Print 2000 I & Biophotonics (Ann Arbor, MI, USA) \\
\hline $\begin{array}{l}\text { Heated magnetic } \\
\text { stirrer }\end{array}$ & & Privileg (Fürth, Germany) \\
\hline Microwave & 8017,8521 & Privileg (Fürth, Germany) \\
\hline Nanoliter injector & & $\begin{array}{l}\text { World Precision Instrument } \\
\text { (Sarasota, FL, USA) }\end{array}$ \\
\hline $\mathrm{pH}$ meter & pH-Meter 611 & $\begin{array}{l}\text { Orion Research Inc (Beverly, MA, } \\
\text { USA) }\end{array}$ \\
\hline Refrigerated aspirator & Unijet II & UniEquip (Martinsried, Germany) \\
\hline
\end{tabular}




\begin{tabular}{|c|c|c|}
\hline Scintillation counter & 1500 Tri-Carb & Packard (Dreieich, Germany) \\
\hline $\begin{array}{l}\text { Speed vac } \\
\text { concentrator }\end{array}$ & SVC $10 \mathrm{CH}$ & Savant (Holbrook, NY, USA) \\
\hline Balance & $\begin{array}{l}2662, \\
\text { T3159M } \\
\text { LC6215 and } \\
2400\end{array}$ & Sartorius (Göttingen, Germany) \\
\hline Spectrophotometer & $\begin{array}{l}\text { GeneQuant II } \\
\text { U2000 }\end{array}$ & $\begin{array}{l}\text { Pharmacia (Uppsala, Sweden) } \\
\text { Hitachi (Tokyo, Japan) }\end{array}$ \\
\hline Mini Fluorimeter & TKO 100 & Hoefer (San Francisco, USA) \\
\hline Laminar Flow & Microflow 51424/1 & Nunc (Wiesbaden, Germany) \\
\hline Thermocyclers & $\begin{array}{l}\text { GeneAmp PCR } \\
\text { system } 2400\end{array}$ & Perkin Elmer (Boston, MA, USA) \\
\hline UV transilluminator & TM40 & UVP Inc (Upland, CA, USA) \\
\hline Vortexer & REAX Top & Heidolph (Schwabach, Germany) \\
\hline Filtration pump & SM18059 & Sartorius (Göttingen, Germany) \\
\hline Membrane Pump & MW71/4 KNF & Neuenberger (Freiburg, Germany) \\
\hline Ultra-Turrax & $\begin{array}{l}\text { IP18-10, } 10 \mathrm{~N} \text { and } \\
18 \mathrm{~K}\end{array}$ & $\begin{array}{l}\text { Jank and Kunkel (Staufen, } \\
\text { Germany) }\end{array}$ \\
\hline Ultrasonicator rod & Laborsonic 2000 & B. Braun (Melsungen, Germany) \\
\hline $\begin{array}{l}\text { Fluorescence } \\
\text { microscope }\end{array}$ & Opton III RS & $\begin{array}{l}\text { Opten Feintechnik (Oberkochen, } \\
\text { Germany) }\end{array}$ \\
\hline Slider camera & Sopt RT & $\begin{array}{l}\text { Diagnostic Instruments (Sterling } \\
\text { Heights, MI, USA) }\end{array}$ \\
\hline $\begin{array}{l}\text { Automated DNA } \\
\text { sequencer }\end{array}$ & ABI Prism & $\begin{array}{l}\text { Applied Biosystems (Laguna } \\
\text { Beach, USA) }\end{array}$ \\
\hline MALDI-TOF/MS & Voyager DE-STR & Applied Biosystems (CA,USA) \\
\hline SELDI-TOF & $\begin{array}{l}\text { ProteinChip } ® \text { SELDI } \\
\text { MS Reader }\end{array}$ & CIPHERGEN (Palo Alto, CA, USA) \\
\hline
\end{tabular}




\section{METHODS}

\subsection{AMPLIFICATION AND QUANTIFICATION OF GENE OF INTEREST BY PCR}

Semi-quantitative RT-PCR experiments were conducted to control the expression of organic anion transporter families in adrenal tissues and $\mathrm{NCl}-\mathrm{H} 295 \mathrm{R}$ cell line.

\subsubsection{Isolation of total RNA from cultured cells}

Total RNA was isolated from semi-confluent NCl-H295R cells using RNeasy mini kit, (QIAGEN, Hilden, Germany). The cells were washed three times with PBS and lysed by addition of an appropriate volume of lysis buffer (RLT plus $\beta$-mercaptoethanol) to the cell-culture dish. The cell lysate was collected with a rubber policeman and passed through QIAshredder spin column, (QIAGEN) for homogenization by 2 min centrifugation at $13,000 \mathrm{rpm}$. One volume of $70 \%$ ethanol was added to the homogenized lysate and was well mixed by pipetting. The samples were then applied to an RNeasy mini column placed and centrifuged for 15 seconds at $13,000 \mathrm{rpm}$. The flow-through was discarded and RNeasy column was washed by adding $700 \mu \mathrm{l}$ washing buffer (RW1) and again centrifuged. The flow-through was discarded and RNeasy column was transferred into a new $2 \mathrm{ml}$ collection tube. RNeasy column was then washed twice with $500 \mu \mathrm{l}$ of RPE buffer by the same procedure as indicated above. RNeasy column was dried by centrifuging for 2 min and transferred to a new $1.5 \mathrm{ml}$ collection tube. To elute the total RNA, $50 \mu \mathrm{l}$ of RNase-free water was directly applied on the RNeasy silica-gel membrane. After two min incubation at RT, total RNA was collected by one min centrifugation. RNA concentration was then determined spectrophotometrically by a GeneQuant RNA/DNA calculator (Pharmacia Biotech, Freiburg, Germany).

\subsubsection{Isolation of total RNA from human adrenal tissues}

The human adrenal tissues were collected directly from the University Hospital surgical department in $\beta$-mercaptoethanol added RNAlater, (QIAGEN), according to the ethical committee recommendations. Lysis buffer (RLT) was added to the RNAlater stabilized tissue and homogenized by brief dips with the Ultra-turrax. The homogenized mixture was centrifuged at 13,000 rpm for $3 \mathrm{~min}$ at RT and supernatant was proceeded to the total RNA isolation steps as described in RNA isolation from cultured cells section (3.1.1). 


\subsubsection{Reverse transcription of mRNA}

RNA-dependent DNA polymerase (M-MLV Reverse Transcriptase, Promega, Mannheim Germany), was used to synthesize cDNA from total RNA, according to the manufacturer's instructions. Two microgram total RNA was taken in the sterile RNase-free $1.5 \mathrm{ml}$ microcentrifuge tube and $0.5 \mu \mathrm{g}$ Oligo(dT) $12-18$ (Invitrogen, Karlsruhe Germany) was added per reaction cup. The tubes were incubated for 5 min at $70^{\circ} \mathrm{C}$ to melt secondary structure within the template and immediately chilled on ice for $5 \mathrm{~min}$ to prevent reformation of secondary structures. Four $\mu$ l of M-MLV 5X reaction buffer, $1 \mu \mathrm{l}$ from $10 \mathrm{mM}$ each dATP, dCTP, dGTP and dTTP (Invitrogen), and 200 units of M-MLV RT were added to the chilled RNA. The total volume of $20 \mu \mathrm{l}$ was obtained by adding RNase and DNase free water. After a brief centrifugation, tubes were incubated at $37^{\circ} \mathrm{C}$ for $60 \mathrm{~min}$. The reaction was stopped by shifting tubes to $70^{\circ} \mathrm{C}$ for 10 minutes in order to inactivate the reverse transcriptase polymerase activity. At the end, the tubes were placed on ice and cDNA was diluted by addition of $200 \mu$ of DNase free water. cDNAs were kept frozen at $-20^{\circ} \mathrm{C}$.

\subsubsection{Polymerase chain reaction (PCR)}

The amplification of genes of interest was carried out with DNA polymerase, (Bio ${ }^{\mathrm{TM}}$ Therm, GeneCraft, Munster, Germany). The reagents for PCR amplification were premixed to ensure identical conditions in each reaction $(20 \mathrm{mM} T$ ris $/ \mathrm{HCl} \mathrm{pH}$ 8.4, $1.5 \mathrm{mM} \mathrm{MgCl}_{2}, 0.2 \mathrm{mM}$ dNTP, 20 pmol primers and $1 \mathrm{U}$ Taq DNA polymerase, in a total volume of $50 \mu \mathrm{l})$. The PCR reaction was performed in a thermocycler (Thermocyclers, 2400, Perkin Elmer, USA) programmed as pre-denaturation, 3 min at $94^{\circ} \mathrm{C}$; denaturation, $40 \mathrm{sec}$ at $94^{\circ} \mathrm{C}$, annealing, $45 \mathrm{sec}$, extension, $1 \mathrm{~min}$ at $72^{\circ} \mathrm{C}$ for $24-32$ cycles and final extension, $5 \mathrm{~min}$ at $72^{\circ} \mathrm{C}$. The annealing conditions and cycles of amplification were changed according to different primers designed for different genes of interest. All the primers used are listed in the tables 2.1-2.4, in Materials chapter. Semi-quantitative PCR analysis was performed by normalizing to the relative amount of cDNA of a housekeeping gene, GAPDH as a control.

\subsubsection{Agarose gel electrophoresis}

After the amplification, PCR products were separated on $1.5 \%$ agarose gels with ethidium bromide staining. Agarose (1-2 \%) was dissolved in TAE buffer (40 mM Tris, $1 \mathrm{mM}$ EDTA-Na $\mathrm{Na}_{2}$-salt and $20 \mathrm{mM}$ acetic acid) by heating in a microwave. After cooling to room temperature, $5 \mu \mathrm{l}$ of $10 \mathrm{mg} / \mathrm{ml}$ ethidium bromide solution was added per $100 \mathrm{ml}$ agarose gel and was poured into the agarose gel chamber. Gels were run 
at $80-100 \mathrm{~V}$ for $1-2$ hours, depending on the size of the examined DNA fragment or on the degree of the band separation required. The gels were visualized under UV light and the density of the detected bands was determined by using PhotoFinish $\circledast$ imaging system (WordStar Atlanta Technology Center, USA). Two independent softwares Lablmage V 2.62 (Kapelan GmbH, Halle, Germany) and One-Dscan V 1.0 (Scanalytics, CSP Inc. CA, USA) were used for comparative quantification of PCR products.

\subsubsection{Purification of PCR product from agarose gel}

The PCR products were purified from agarose gels to confirm the product by sequencing. For this purpose gel bands of respective size were excised from the agarose gel and gel extraction kit (QIAquick Gel Extraction Kit, QIAGEN) was used to purify the PCR product. Three volumes of binding and solubilization buffer (QB) was added to one volume of gel and incubated at $50^{\circ} \mathrm{C}$ until the gel slices were completely dissolved. To bind DNA, the solution was added to the QIAquick column and centrifuged at $13,000 \mathrm{rpm}$ for $1 \mathrm{~min}$. During the DNA absorption step, DNA fragments bind to the silica membrane, whereas primers, enzymes, nucleotides, agarose and ethidium bromide do not bind. The DNA bound on the column was washed again with buffer (QB) followed by washing with ethanol-containing buffer (PE), which washes salts off. Any residual PE buffer was removed by an additional one min centrifugation step. Fifty ml EB buffer (10 mM Tris- $\mathrm{HCl}, \mathrm{pH} 8.5)$ or $\mathrm{H}_{2} \mathrm{O}(\mathrm{pH}$ 7.0-8.5) was then applied to elute the DNA and collected by centrifuging the column for one min at $14,000 \mathrm{~g}$.

\subsubsection{Sequencing of the PCR product (non-radioactive dye terminated sequencing of DNA)}

The DNA fragments amplified by PCR in the present study were sequenced in nonradioactive dye terminated cycle sequencing (Applied Biosystems, Darmstadt, Germany) at the Department of Biochemistry, University of Göttingen. A $10 \mu \mathrm{l}$ sequencing PCR reaction was prepared by mixing $800 \mathrm{ng}$ of template DNA (purified PCR product), $1 \mu \mathrm{l}$ of $10 \mathrm{pmol}$ primer, $2.5 \mu \mathrm{l}$ sequence mix and DNase, RNase free $\mathrm{H}_{2} \mathrm{O}$ to make a total volume of $10 \mu \mathrm{l}$. The following PCR program was used: $96^{\circ} \mathrm{C}$ for $10 \mathrm{sec}, 55^{\circ} \mathrm{C}$ for $5 \mathrm{sec}$, and $60^{\circ} \mathrm{C}$ for $4 \mathrm{~min}$. After 25 cycles, the amplified DNA was precipitated in sodium acetate in ethanol solution (50 $\mu$ l95\% ethanol plus $5 \mu \mathrm{l} 3 \mathrm{M}$ sodium acetate) and centrifuged at $14,000 \mathrm{rpm}$ for $20 \mathrm{~min}$. The supernatant was discarded, and the DNA pellet was washed in $250 \mu \mathrm{l} 70 \%$ ethanol and centrifuged for 
10 min. The supernatant was discarded and pellet was dried by Speed Vac and the DNA was dissolved in $25 \mu \mathrm{l}$ DNase and RNase free $\mathrm{H}_{2} \mathrm{O}$.

\subsection{CULTIVATION OF HUMAN ADRENOCORTICAL CARCINOMA CELLS (NCI-H295R)}

\subsubsection{Culture media}

Human adrenocortical cells (NCl-H295R, CRL-2128, ATCC, USA) were grown in 75 $\mathrm{cm}^{2}$ flasks (Falcon, Lincoln Park, NJ USA) at $37^{\circ} \mathrm{C}$ with $5 \% \mathrm{CO}_{2}$ at a $1: 1$ ratio of Dulbecco's Modified Eagle's Media and Nutrient Mixture F-12 Ham, containing 15 mM HEPES, $1 \mathrm{ml}$ ITS $^{+}$Premix/100 ml media $(6.25 \mu \mathrm{g} / \mathrm{ml}$ insulin, $6.25 \mu \mathrm{g} / \mathrm{ml}$ transferrin, $6.25 \mathrm{ng} / \mathrm{ml}$ selenium, $1.25 \mathrm{mg} / \mathrm{ml}$ bovine serum albumin, $5.35 \mu \mathrm{g} / \mathrm{ml}$ linoleic acid), $1 \mathrm{ml}$ of 10,000 units penicillin and 10,000 $\mu \mathrm{g}$ streptomycin solution, $1 \mathrm{ml}$ of $200 \mathrm{mM}$ glutaric acid, in $100 \mathrm{ml}$ medium, $2.73 \mathrm{ml} \mathrm{Nu}$-serum/100 ml media.

\subsubsection{Dissociation of cells from culture flasks}

The cells were removed from the substratum by gentle treatment using the following protocol in order to maintain cellular integrity.

The culture media was removed, and the cells were washed using pre-warmed PBS. The dissociation solution ( $0.25 \%$ trypsine, $0.03 \%$ EDTA solution in PBS) was added to the side of the flask, opposite to the cells $\left(2.5 \mathrm{ml} / 25 \mathrm{~cm}^{2}\right)$ and incubated $5 \mathrm{~min}$ at $37^{\circ} \mathrm{C}$. At the end of the incubation, flask was rocked gently and the reaction was stopped by addition of culture media. The solution was centrifuged at 1,000 rpm for 5 min and supernatant was discarded. The cells were resuspended in complete media, counted and sub-cultured. The cell medium was changed twice a week.

\subsubsection{Cryopreservation}

All experiments were performed using the cells between passages 15-50. The cells were cryopreserved to avoid loss by contamination, and to minimize genetic change. The cells were detached from the substrate by using a dissociation solution $(0.25 \%$ trypsine, $0.03 \%$ EDTA solution in PBS) and, after centrifugation, resuspended in complete medium and the cell count was established. The cells were aliquoted in a concentration between $\tilde{1} 5 \times 106$ cells/ml in freezing medium (95\% complete culture medium plus $7.5 \%$ Nu-Serum: $5 \%$ DMSO). The cryogenic storage vials were placed 
on ice, and within 5 min stored at $80^{\circ} \mathrm{C}$ overnight. Finally, the vials were stored in liquid nitrogen.

\subsubsection{Thawing of cryopreserved cells}

The cells were quickly thawed in a $37^{\circ} \mathrm{C}$ water bath after being removed from liquid nitrogen. Then the cells were mixed directly into complete culture medium $(1 \mathrm{ml}$ frozen cells: $10 \mathrm{ml}$ complete medium) and centrifuged at $1000 \mathrm{rpm}$ for $5 \mathrm{~min}$ to remove cryopreservative (DMSO). The cells were resuspended in complete culture medium and seeded in culture flasks.

\subsection{CORTISOL RELEASE FROM NCI-H295R CELLS AND ITS INHIBITION}

Cells used for experiments were subcultured from the $80 \%$ confluent stock cultures into six-well culture plates at least $24 \mathrm{~h}$ before the start of experiment. At the beginning of experiment, cells were washed three times with $2 \mathrm{ml}$ pre-warmed PBS. Sequential $6,12,24$, and $48 \mathrm{~h}$ incubations were conducted on each set of plates with $2 \mathrm{ml}$ complete medium in the absence or presence of $10 \mu \mathrm{M}$ or $20 \mu \mathrm{M}$ forskolin, 10 $\mathrm{nM}$ or $20 \mathrm{nM} \mathrm{ACTH}$, or $100 \mu \mathrm{M}$ DHEA sulfate. At the end of each incubation period, the medium was removed from each well and kept at $-20^{\circ} \mathrm{C}$ until cortisol measurement.

The cortisol release and its inhibition by probenecid, $\mathrm{PAH}$, cimetidine, or glutarate, were determined in cells pre-stimulated with $10 \mu \mathrm{M}$ forskolin for 24 hours. After aspiration of the pre-incubation medium, each well was washed three times with $2 \mathrm{ml}$ pre-warmed PBS, and again incubated with $2 \mathrm{ml}$ medium containing $10 \mu \mathrm{M}$ forskolin with or without different concentrations of test substances, i.e. probenecid, $\mathrm{PAH}$, cimetidine or glutarate. When the incubation period, usually $24 \mathrm{~h}$, was over, medium samples were taken and kept frozen at $-20^{\circ} \mathrm{C}$ until assayed for cortisol concentration. The protein concentration was determined with the Bradford method (Bradford 1976) using serum albumin as a standard.

\subsubsection{Determination of cortisol by radioimmunoassay (RIA)}

The concentrations of cortisol in the culture supernatants were determined by a radioimmunoassay (RIA). Ten microlitre culture supernatant was used to determine cortisol contents. The RIA was performed in the Department of Experimental and Clinical Endocrinology by Mrs. Metten. The antiserum was raised against 
corticosterone, but showed $100 \%$ cross-reactivity with cortisol. The cross-reactivity with other steroids like aldosterone, progesterone, androstenedione, estrone sulfate, dehydroepiandrosterone sulfate or testosterone was less than $0.1 \%$. The limit of detection of RIA for cortisol was $1 \mathrm{ng} / \mathrm{ml}$.

\subsection{UPTAKE OF RADIOACTIVE SUBSTANCES INTO THE NCI-H295R CELLS}

The $\mathrm{NCl}-\mathrm{H} 295 \mathrm{R}$ cells were sub-cultured in 6 -well or 24 well plates at least 48 hours before the start of the experiment. After washing the cells with pre-warmed PBS buffer, the cells were incubated with medium with or without $10 \mu \mathrm{M}$ forskolin. At the start of experiment the cells were washed three times with pre-warmed mammalian Ringer solution. The uptake of organic anions was performed by incubating the cells in a transport medium with $5 \mu \mathrm{Ci} / \mathrm{ml}\left[{ }^{3} \mathrm{H}\right]$ para-aminohippurate in Ringer solution with or without test substances for $15 \mathrm{~min}$ at $\mathrm{RT}$, or in $0.44 \mu \mathrm{Ci} / \mathrm{ml}\left[{ }^{3} \mathrm{H}\right]$ estrone sulfate or in $0.74 \mu \mathrm{Ci} / \mathrm{ml} \mathrm{[}{ }^{3} \mathrm{H}$ ] dehydroepiandrosterone sulfate in Ringer solution with or without test substances for $10 \mathrm{~min}$ at RT. The plates remained in gently shaking motion during the incubation period. The uptake was terminated by removing the transport medium and washing the cells three times with ice-cold Ringer solution. The cells were lysed by incubating one hour with $0.5 \mathrm{ml}$ of $1 \mathrm{M}$ sodium hydroxide. Then $0.5 \mathrm{ml}$ $1 \mathrm{M}$ hydrochloric acid was added for neutralization. The $0.9 \mathrm{ml}$ of cell lysate was added to $4 \mathrm{ml}$ scintillation cocktail (Ultima Gold; Packard, Dreieich Germany) and the radioactivity taken up by the cells was measured by a liquid scintillation counter (TriCARB 2100TR, Packard). The protein concentration was determined by the Bradford method (Bradford 1976) and serum albumin as a standard.

\subsection{CULTIVATION OF HEK-293 CELLS}

Human embryonic kidney (HEK-293) (Graham et al. 1977) were stably transfected with Tetracycline-Regulated Expression (T-REx ${ }^{\mathrm{TM}}$ ) system (Invitrogen) were used in the present study. The HEK-293 cells stably transfected with 1) control vector, 2) hOAT1 gene (Acc. B1765233), 3) hOAT3 gene (Acc. BI760120, repaired by Bakhiya (Bakhiya et al. 2003), and 4) hOAT4 gene (Acc. AL614126), were used in the present study. The cloned genes were provided by Dr. Bahn (Göttingen, Germany), and stable transfections were done by Dr. Ugele (Munich, Germany). 


\subsubsection{Culture media}

HEK-293 cells were grown in $25 \mathrm{~cm}^{2}$ flasks (Falcon, Lincoln Park, NJ USA) at $37^{\circ} \mathrm{C}$ with Dulbecco's Modified Eagle's Media (high glucose), 10\% FBS, 2 mM L-glutamine, $1 \%$ Pen-Strep, $5 \mu \mathrm{g} / \mathrm{ml}$ blasticidin and in $5 \% \mathrm{CO}_{2}$.

The dissociation of HEK-293 cells was done by incubating the cells 5 min with dissociation solution (EGTA $1 \mathrm{mM}, \mathrm{NaCl} 85 \mathrm{mM}$, NaHCO3 $17.5 \mathrm{mM}, \mathrm{KCl} 3.9 \mathrm{mM}$, $\mathrm{KH}_{2} \mathrm{PO}_{4} 0.8 \mathrm{mM}$ and $10 \mathrm{mM}$ glucose) and procedure as described in section (3.2.2).

Cryopreservation and thawing of HEK-293 cells was done as described in section (3.2.3 and 3.2.4) by using the freezing medium [ $45 \%$ complete medium, $45 \%$ conditioned complete medium (medium one day utilized by the cells), and $10 \%$ DMSO].

\subsubsection{Uptake of radiolabeled substances into HEK-293 cells}

HEK-293 cells were grown in $100 \mathrm{~mm}$ culture plates at $37^{\circ} \mathrm{C}$ with $5 \% \mathrm{CO}_{2}$. The cells were subcultured in 24 well plates at least 48 hours before the start of the experiment. Cells were washed three times with pre-warmed mammalian Ringer solution. The uptake of organic anions was measured by incubating the cells with transport medium containing $5 \mu \mathrm{Ci} / \mathrm{ml}\left[{ }^{3} \mathrm{H}\right] \mathrm{PAH}, 0.44 \mu \mathrm{Ci} / \mathrm{ml}\left[{ }^{3} \mathrm{H}\right]$ estrone sulfate, 0.74 $\mu \mathrm{Ci} / \mathrm{ml}\left[{ }^{3} \mathrm{H}\right]$ dehydroepiandrosterone sulfate, or $1.0 \mu \mathrm{Ci} / \mathrm{ml}\left[{ }^{3} \mathrm{H}\right]$ cortisol in Ringer solution at room temperature for $1 \mathrm{~min}$. The uptake was stopped by removing the transport medium and subsequently washings three times with ice-cold Ringer solution. The cells in each well were lysed with $0.5 \mathrm{ml}$ of $1 \mathrm{M}$ sodium hydroxide and then neutralized by addition of $0.5 \mathrm{ml} 1 \mathrm{M}$ hydrochloric acid. The $0.9 \mathrm{ml}$ of cell lysate was taken along with $4 \mathrm{ml}$ scintillation cocktail (Ultima Gold; Packard, Dreieich Germany) to estimate the radioactivity taken up by the cells and measured with liquid scintillation counter (Tri-CARB 2100TR, Packard). Remaining $100 \mu \mathrm{l}$ of cell lysate was used to determine the protein concentration by the Bradford method (Bradford 1976).

\subsection{CULTIVATION AND TRANSIENT TRANSFECTION IN COS-7 CELLS}

\subsubsection{Culture media}

African green monkey kidney cells (COS-7), (DSMZ-GmbH, Braunschweig, Germany) were grown in $100 \mathrm{~mm}$ culture plates at $37^{\circ} \mathrm{C}$ with $5 \% \quad \mathrm{CO}_{2}$. 
Morphologically fibroblast-like cells were growing as monolayer. The culture media contained: 90\% Dulbecco's Modified Eagle Medium (DMEM) with GlutaMAX, 10\% FCS. $1.25 \mathrm{mg} / \mathrm{ml}$ bovine serum albumin, $5.35 \mu \mathrm{g} / \mathrm{ml}$ linoleic acid, $1 \mathrm{ml}$ of 10,000 units penicillin and 10,000 $\mathrm{gg}$ streptomycin solution, one $\mathrm{ml}$ of $200 \mathrm{mM}$ glutaric acid, in 100 $\mathrm{ml}$ medium (Gibco/Invitrogen).

\subsubsection{Transfection of COS-7 cells by electroporation}

COS-7 cells were transfected by electroporation. The COS-7 cells were grown confluent in $100 \mathrm{~mm}$ tissue culture dishes. The medium was discarded, following by twice washing with pre-warm PBS. The cells were then trypsinized and collected in cold PBS. After 5 min centrifugation at $800 \mathrm{rpm}$ and $4^{\circ} \mathrm{C}$, the pellet cells were again dissolved in $1 \mathrm{ml}$ cold PBS.

$5 \mu \mathrm{g}$ DNA plasmid $(1 \mu \mathrm{g} / \mu \mathrm{l})$ was added in to pre-chilled electroporation cuvette and incubated for $10 \mathrm{~min}$. The cell suspension (2.5x106 cells in $200 \mu \mathrm{l}$ volume) was pipetted in one electroporation cuvette and electroporated on $250 \mathrm{~V} / 300 \mu \mathrm{F}$. The cuvette was then immediately chilled on ice for 5 min followed by 5 min incubation at room temperature.

After adding the medium without penicillin/streptomycin and mixing, cells were plated in $100 \mathrm{~mm}$ culture plates for 24 hours. After 24 hours cells were collected by trypsination and cultured in 24 well plates. The experiments were performed 48 hours after plating the cells in the 24 well plates. The uptake of radiolabeled substances into COS-7 cells was performed as described in section (3.4) for NCl-H295R cells.

\subsection{EXPRESSION OF TRANSPORTER PROTEIN IN Xenopus laevis OOCYTES}

To clarify the role of members of organic anion transporter and organic anion transporter polypeptide family in cortisol uptake, we expressed them in Xenopus laevis oocytes.

\subsection{1 cRNA sycthesis}

For expressing the transporter proteins in Xenopus laevis oocytes, cRNA was synthesized using plasmids containing genes of interest. The PCMV-SPORT6 and T7 vector containing hOAT1, hOAT2, hOAT3, hOAT4, OATP-A or OATP-B were used in the present investigation. After linearization the plasmid with Notl enzyme, in-vitro 
synthesis of cRNA was done using SP6 and T7 mMESSAGE mMACHINE kit (Ambion, Austin, TX, USA).

The $5 \mu \mathrm{g}$ plasmid DNA, containing gene of interest was linearized with Notl $(5 \mathrm{U} / \mu \mathrm{g}$ DNA) digestion for 3 hours at $37^{\circ} \mathrm{C}$. The DNA was purified using the PCR-purification kit from QIAGEN as described above in section (3.1.6). For cRNA synthesis a $20 \mu \mathrm{l}$ reaction mixture consisted of $2 \mu \mathrm{l} 10 \mathrm{x}$ reaction buffer, $10 \mu \mathrm{l} 2 \mathrm{x}$ ribonucleotide mix for SP6 (10 mM ATP, $10 \mathrm{mM}$ CTP, $10 \mathrm{mM}$ UTP, $2 \mathrm{mM}$ GTP, and $8 \mathrm{mM}$ cap analog) and for T7 (15 mM ATP, $15 \mathrm{mM}$ CTP, $15 \mathrm{mM}$ UTP, $3 \mathrm{mM}$ GTP, and $12 \mathrm{mM}$ cap analog), one $\mu \mathrm{g}$ linearized plasmid DNA, $2 \mu \mathrm{l}$ enzyme mix (buffer plus RNA polymerase) and RNase free water was prepared. The reaction mix was incubated at $37^{\circ} \mathrm{C}$ for 2 hours, then the template DNA was removed by digestion with DNasel (DNasel RNnaselfree in $50 \%$ glycerol buffer) at $37^{\circ} \mathrm{C}$ for $15 \mathrm{~min}$. The reaction was stopped by addition of $30 \mu \mathrm{l}$ nuclease free water and $30 \mu \mathrm{l}$ precipitation solution $(7.5 \mathrm{M}$ lithium chloride and $50 \mathrm{mM}$ EDTA) in the reaction tube. The samples were incubated at $-20^{\circ} \mathrm{C}$ for 2 hours. The cRNA was collected by centrifuging at $14,000 \mathrm{rpm}$ for $15 \mathrm{~min}$ at $4^{\circ} \mathrm{C}$ followed by washing with $70 \%$ ethanol. The cRNA was resuspended in $10 \mu$ l RNase free water and the concentration was determined spectrophotometrically at GeneQuant RNA/DNA calculator (Pharmacia Biotech). Samples were diluted to one $\mu \mathrm{g} / \mu \mathrm{l}$ concentration and stored at $-80^{\circ} \mathrm{C}$.

\subsubsection{CRNA injection into Xenopus laevis oocytes}

Stage V-VI oocytes were collected and defolliculated by overnight incubation with 0.5 $\mathrm{mg} / \mathrm{ml}$ collagenase Type CLSII (Biochrom, Berlin, Germany) at $18^{\circ} \mathrm{C}$ in oocytes Barth's solution (88 mM NaCl, $1 \mathrm{mM} \mathrm{KCl}, 0.3 \mathrm{mM} \mathrm{Ca}\left(\mathrm{NO}_{3}\right)_{2}, 0.41 \mathrm{mM} \mathrm{CaCl}, 0.82$ $\mathrm{mM} \mathrm{MgSO}_{4}, 15 \mathrm{mM}$ HEPES, $10 \mathrm{mg} / \mathrm{l}$ Gentamicin $\mathrm{pH}$ set at 7.6 with $\mathrm{NaOH}$ ). Oocytes were injected with $23 \mathrm{nl}$ of water $\left(\mathrm{H}_{2} \mathrm{O}\right)$ or with $23 \mathrm{ng}$ cRNA $(1 \mathrm{ng} / \mathrm{nl})$ of human OAT1, OAT2, OAT3, OAT4, OATP-A or OATP-B in an equivalent volume. Upon injection, the oocytes were incubated for three days at $18^{\circ} \mathrm{C}$ in modified oocytes Barth's solution containing $12 \mu \mathrm{g} / \mathrm{ml}$ gentamycin.

\subsubsection{Uptake of radiolabeled substance by transporter expressing Xenopus laevis oocytes}

To determine the ability of human OAT1, OAT2, OAT3, OAT4, OATP-A and OATP-B proteins for $\left[{ }^{3} \mathrm{H}\right]$ cortisol transport, Xenopus laevis oocytes were injected with the respective cRNAs. The water injected oocytes were used as control. For the uptake experiments, the cRNA or water injected control oocytes were incubated with oocyte 
Ringer solution (ORI) $(90 \mathrm{mM} \mathrm{NaCl}, 3 \mathrm{mM} \mathrm{KCl}, 2 \mathrm{mM} \mathrm{CaCl} 2,1 \mathrm{mM} \mathrm{MgCl}, 5 \mathrm{mM}$ HEPES/Tris, $\mathrm{pH} 7.6)$ containing, $\left[{ }^{3} \mathrm{H}\right]$ estrone sulfate $(0.44 \mu \mathrm{Ci} / \mathrm{ml}), \quad\left[{ }^{3} \mathrm{H}\right] \mathrm{p}$ aminohippurate $(5 \mu \mathrm{Ci} / \mathrm{ml}),\left[{ }^{3} \mathrm{H}\right] \mathrm{DHEA}$-sulfate $(0.74 \mu \mathrm{Ci} / \mathrm{ml})$, or $\left[{ }^{3} \mathrm{H}\right]$ cortisol $(1.4$ $\mu \mathrm{Ci} / \mathrm{ml}$ ) for one hour. At the end of the incubation period, uptake was terminated by aspiration of the incubation medium and three times washing with $5 \mathrm{ml}$ ice-cold ORI. Each oocyte was placed in separate scintillation cup and dissolved in $0.1 \mathrm{ml}$ of $1 \mathrm{M}$ $\mathrm{NaOH}$. After neutralization with $0.1 \mathrm{ml}$ of $1 \mathrm{M} \mathrm{HCl}$, the radiolabeled contents were assayed by liquid scintillation counting.

\section{$3.8 \quad$ IMMUNOSTAINING OF NCI-H295R CELLS AND ADRENAL TISSUES}

\subsubsection{Preparation of cells for immunostaining}

The cells from semi-confluent flasks were seeded on sterile $1 \mathrm{~cm}$ round glass cover slips, placed in the 6 well cultures 48 hours before the start of experiment. In order to determine the effect of forskolin and DHEAS stimulation on the expression of OATs, the cells were stimulated with medium containing $10 \mu \mathrm{M}$ of forskolin or $100 \mu \mathrm{M}$ of DHEAS or without any stimulation as a control, for $24 \mathrm{~h}$. At the end of stimulation, cells were washed three times with PBS at RT and incubated with freshly prepared $4 \%$ para-formeldehyde in PBS at $4^{\circ} \mathrm{C}$ for 24 hours. After that cells were thoroughly washed with PBS, and remained dip in PBS with $0.2 \%$ sodium azide $\left(\mathrm{NaN}_{3}\right)$ at $4{ }^{\circ} \mathrm{C}$ until immunostaining.

\subsubsection{Immunostaining of cells}

Storage medium PBS with $\mathrm{NaN}_{3}$ was discarded and cells on cover slips were washed twice with PBS at RT. Cells were then permeabilized by incubating in $0.5 \%$ Triton X-100 for $10 \mathrm{~min}$. The cells were blocked by $30 \mathrm{~min}$ incubation with blocking solution (1\% BSA in PBS) at RT to avoid the unspecific binding of the antibody. A commercial monoclonal antibody anti $\alpha$-tubulin was used to stain microtubules, and polyclonal rabbit anti-rat OAT3 C-terminus antibody from Alpha-Diagnostic (TX, USA) and rabbit anti-rat OAT3 $\mathrm{N}$-terminus polyclonal antibody provided by Dr. Endou (Japan) was used to stain hOAT3. The antibodies were diluted to $50 \mathrm{ng} / \mu \mathrm{l}$ in blocking PBS solution. About $80 \mu$ of the diluted antibody was applied to each cover slip and incubated for 2 hours at room temperature or $12-14$ hours at $4^{\circ} \mathrm{C}$, in a moisturized box. At the end of incubation period, cells were washed 2 times with $0.1 \%$ Triton $X-$ 100 for $10 \mathrm{~min}$. 
The CY3-labeled goat anti rabbit IgG (GARCY3) (Jackson ImmunoResearch Laboratories, PA, USA) was used as second antibody against Endou's and Alpha-diagnostic OAT3 antibody. Donkey anti-mouse IgG (DAMCY3) (Jackson) was used for monoclonal antibodies against a-tubulin. Both second antibodies (DAMCY3 and GARCY3) were diluted to $2.5 \mathrm{ng} / \mu \mathrm{l}$ using blocking PBS solution. The cells incubated with second antibody for two hours at room temperature in a moisturized box. The cells were then washed twice with PBS and the cover slips were mounted over glass slides by using fluorescence fading retardant (Vectashield, Vector Laboratories Inc., Burlingame, CA, USA), making sandwich of cells between cover slip and glass slide. The excess mounting liquid was aspirated and cover slips were sealed in place with clear nail polish.

\subsubsection{Immunostaining of paraffin embedded adrenal tissue sections}

The paraffin embedded tissue sections were first washed in PBS and then with PBS containing $0.5 \%$ Triton $\mathrm{X}-100$ for $15 \mathrm{~min}$. The sections were then incubated with PBS plus $2 \%$ Triton $\mathrm{X}-100$ for $30 \mathrm{~min}$ at room temperature followed by $30 \mathrm{~min}$ blocking by incubating in blocking solution. The primary antibody was then applied (anti $\alpha$-tubulin antibody, diluted $20 \mathrm{ng} / \mu \mathrm{l}$ in blocking PBS, and OAT3, diluted $50 \mathrm{ng} / \mu \mathrm{l}$ in PBS) over night at $4^{\circ} \mathrm{C}$. After washing with PBS plus $0.5 \%$ TritonX-100 tissue sections were incubated with optimal concentrations of $2.5 \mathrm{ng} / \mu \mathrm{LAMCY} 3$ or GARCY3 at room temperature for 2 hour. At the end of incubation period the tissues were washed twice with PBS and mounted in fluorescence fading retardant (Vectashield). The excess mounting liquid was aspirated and cover slips were sealed in place with clear nail polish.

The stained sections and cells were examined and photographed with Opton III RS fluroresence microscope (Opten Feintechnik, Oberkochen, Germany), using a sopt RT Slider camera and software (Diagnostic Instruments, Sterling Heights, MI, USA). The photos were imported into Adobe Photoshop 6.0 and processed and labelled as required. These experiments were performed at the Institute for Medical Research \& Occupational Health, Zagreb, Croatia, during a study financed by BMFT. 


\subsection{PREPARATION OF CYTOSOL AND MEMBRANE FRACTIONS OF NCI-H295R CELLS}

Total cell lysate (TCC), total cell membrane (TCM) and cytosolic fraction of $\mathrm{NCl}$ $\mathrm{H} 295 \mathrm{R}$ cells were prepared by using confluent $75 \mathrm{~cm}^{2}$ flasks. The cells were first incubated with medium containing $10 \mu \mathrm{M}$ forskolin, or $100 \mu \mathrm{M}$ DHEAS or control medium without any stimulation for 24 hours. The cell fractions were prepared by ultra-centrifugation. First of all cells culture flasks were cooled down on ice followed by three washings with pre-cooled PBS. Two $\mathrm{ml}$ of membrane buffer1 ( $\mathrm{NaCl} 150 \mathrm{mM}$, Tris/HCl $50 \mathrm{mM} \mathrm{pH} \mathrm{7.5,} \mathrm{EDTA} 5 \mathrm{mM}$, PMSF $0.1 \mathrm{mg} / \mathrm{ml}$, aprotinin $4 \mathrm{ng} / \mathrm{ml}$, leupeptin 4 $\mathrm{ng} / \mathrm{ml}$ ) or BBMV buffer (300 mM mannitol, 5 mM EGTA, $12 \mathrm{mM}$ Tris/HCl, pH 7.4) was added to each flask and cells were scraped off using a rubber policeman into $15 \mathrm{ml}$ tubes. The cells were disrupted by three brief dips of pre-chilled Ultra-sonication rod at high speed. The disrupted mixture of cells was centrifuged for $10 \mathrm{~min}$ at $1000 \mathrm{~g}$ and $4^{\circ} \mathrm{C}$. The supernatant obtained was the TCL. Pellet containing nuclei and unbroken cells were discarded. A part of $\mathrm{TCL}$ was kept at $-20^{\circ} \mathrm{C}$ for immunobloting. The TCL was then used to make cytosol and TCM fractions.

The TCL was ultra-centrifuged at 50,000 rpm $(167,300 \mathrm{~g})$ for $45 \mathrm{~min}$ at $4^{\circ} \mathrm{C}$. The supernatant was a pure cytosol fraction of the cells, while the pellet fraction was total plasma membrane (TCM). After pipetting out the cytosol fraction, the tubes were washed three times gently with ice-cold membrane buffer to remove all cytosolic proteins. The pellet (TCM) was then dissolved in ice-cold membrane buffer or PBS to estimate protein concentration by the Bradford test (Bradford 1976) and kept frozen at $-80^{\circ} \mathrm{C}$.

\subsection{WESTERN BLOT ANALYSIS}

Western blot analysis for hOAT3 in NCl-H295R cells was performed according to following procedure. The TCL and TCM fractions from $\mathrm{NCl}-\mathrm{H} 295 \mathrm{R}$ cells were prepared as described above in cell fractionation section (3.9). Proteins were denatured in sample buffer ( $1 \%$ SDS, $12 \%$ v/v glycerol, $5 \% \beta$-mercaptoethanol, 30 $\mathrm{mM} \mathrm{Tris} / \mathrm{HCl}, \mathrm{pH} 6.8$ ) at $37^{\circ} \mathrm{C}$ for $30 \mathrm{~min}$. The proteins were separated through $12 \%$ mini SDS-PAGE (0.375 M Tris- $\mathrm{HCl}(\mathrm{pH} 8.8)$ and $0.12 \%$ SDS and $0.025 \%$ TEMED and amionium persulfate). Electrophoresis was performed at constant current (20 mA per gel) for $2 \mathrm{~h}$ in electrophoresis buffer (2.5 mM Tris and $20 \mathrm{mM}$ Glycine and $0.1 \%$ SDS). Subsequent to the protein separation by gel electrophoresis, proteins were electronically transferred to PVDF membrane (Immobilon, Millipore, Bedford, MA, 
USA). The transfer membrane was briefly stained with Coomassie Brilliant Blue (CBB) to check the efficiency of the transfer. After destaining, the membrane was blocked by incubating in the blotting buffer ( $5 \%$ non-fat dry milk, $0.15 \mathrm{M} \mathrm{NaCl}, 0.02 \%$ $\mathrm{NaN}_{3}, 1 \%$ Triton $\mathrm{X}-100,20 \mathrm{mM}$ Tris/HCl, $\mathrm{pH}$ 7.4). The membranes were then incubated with blotting buffer containing hOAT3 antibody $(2 \mathrm{ng} / \mu \mathrm{l})$ over night at $4^{\circ} \mathrm{C}$. Following intensive washing in the antibody-free blotting buffer, the transfer membranes were further incubated for one hour in the blotting buffer that containing $(0.1 \mathrm{mg} / \mathrm{ml})$ GARAP (alkaline phosphatase-labeled goat anti-rabbit IgG (Vector Laboratories, Burlingame, CA). After washing twice with blotting buffer, membranes were stained for alkaline phosphatase activity with the BCIP/NBT method. The stained membranes were scanned using an Epson Scanner (USA) to make the densitometry evaluations of the stained bands.

\subsection{TWO-DIMENSIONAL GEL ELECTROPHORESIS OF PROTEINS}

\subsubsection{First dimension electrophoresis}

Proteins were separated in the first dimension by isoelectric focusing (IEF), which separates proteins by their IP value. IEF could be described as electrophoresis in a $\mathrm{pH}$ gradient set up between a cathode and anode with the cathode at a higher $\mathrm{pH}$ than the anode. Because of the amphoteric propertites of amino acids, the proteins will be positively charged at $\mathrm{pH}$ values below their isoelectric $\mathrm{pH}(\mathrm{IpH})$ and negatively charged above. Under the influence of the electrical force the $\mathrm{pH}$ gradient will be established by the carrier ampholytes, and the protein species migrate and focus (concentrate) at their isoelectric points.

\subsubsection{Sample preparation for first dimension}

Seven centimetres and seventeen centimetres immobilized pH gradients (IPG) strips (ReadyStrip IPG, BioRad, München, Germany) with pH range 3-10 were used in these experiments. The amount of protein loaded on each IPG was varied with method of staining. The gels were either stained by Coomassie Brilliant Blue (CBB) or by silver staining method. The total protein and volume load for IPG strips are summarized in table 3.1 . 


\begin{tabular}{llll}
\hline IPG strip & Volume $(\mu \mathrm{l})$ & Protein load $(\mu \mathrm{g})$ & \\
\hline \multirow{3}{*}{$7 \mathrm{~cm}$} & & CBB Staining & Silver staining \\
\cline { 3 - 4 } $17 \mathrm{~cm}$ & 135 & 200 & 50 \\
& 330 & $400-700$ & 200
\end{tabular}

Table 3.1 The protein and volume load of IPG strips The amount of protein and the volume of the sample for $7 \mathrm{~cm}$ and $17 \mathrm{~cm}$ long IPG strips for Coomassie Brilliant Blue (CBB) and silver staining protocols.

The total cell lysate (TCL) was prepared by washing the culture plates three times with PBS, followed by collection of cells by a rubber policeman in PBS. The cells were pelleted by centrifugation and PBS was removed. The cell pellet was then directly dissolved in an appropriate volume of Reha buffer (7 M urea, $2 \mathrm{M}$ thiourea, 4\% CHAPS, $15 \mathrm{mM}$ DTT and 2\% ampholyte). Total cell membrane (TCM) and cytosol fraction were prepared as described in section (3.9). The TCM pellet was directly dissolved in the Reha buffer. The cytosol fraction was precipitated by adding three volumes of acetone in one volume of cytosol followed by two hours incubation at $-20^{\circ} \mathrm{C}$. At the end of incubation period, samples were centrifuged at $14,000 \mathrm{rpm}$ for $20 \mathrm{~min}$ at $4^{\circ} \mathrm{C}$. The supernatant was discarded and the pellet was completely dried at room temperature. The pellet was then dissolved in an appropriate volume of Reha buffer. The protein concentration was determined (Bradford 1976). The samples were diluted to the desired concentration by addition of rehydration buffer ( 7 $\mathrm{M}$ urea, $2 \mathrm{M}$ thiourea, $0.5 \%$ CHAPS, $15 \mathrm{mM}$ DTT and $0.2 \%$ ampholyte). The bromophenol blue was added to the sample for visualization protein migration in the strips during IEF.

\subsubsection{Isoelectric focusing of proteins}

IPG strips rehydration was carried out in the reswelling cassette (BioRad). The appropriate volume and amount of protein as described in table (3.1), were carefully applied onto the cassette track for strip rehydration. The protective film from the strips was removed and they were placed (gel down) into the cassette without air bubbles. The samples were incubated at room temperature for $30 \mathrm{~min}$. After that, a layer of mineral oil (BioRad) was applied over the IPG strips to avoid the evaporation and was passively rehydrated (without any electric field) over night. The isoelectric focusing was carried out at following running conditions: $500 \mathrm{~V}$ for $1 \mathrm{Vh} ; 1500 \mathrm{~V}$ for 1 $\mathrm{Vh} ; 4500 \mathrm{~V}$ for $1 \mathrm{Vh}$ and $8000 \mathrm{~V}$ for at least $1 \mathrm{Vh}$ for $7 \mathrm{~cm}$ IPG strip. The total 
gradient was $10000 \mathrm{Vh}$ at the end. While $17 \mathrm{~cm}$ strips were focused at $500 \mathrm{~V}$ for 1 $\mathrm{Vh} ; 4500$ for $1 \mathrm{Vh} ; 8000$ for $1 \mathrm{Vh}$ and total gradient was $31000 \mathrm{Vh}$ at the end.

\subsubsection{Equilibration of proteins for SDS-PAGE}

In order to load IPG strips into SDS-PAGE to separate protein into second dimension, it is necessary to reduce all the cysteines present in the protein. This step was carried out by incubating the IPG strips with equilibration buffer 1 (6 M urea, 2\% SDS, 30\% glycerin, $150 \mathrm{mM}$ Tris, $\mathrm{pH} 8.8$, and $2 \%(\mathrm{w} / \mathrm{v}) \mathrm{DDT})$ for $20 \mathrm{~min}$. After this strips were incubated with equilibration buffer 2 (6 M urea, $2 \%$ SDS, $30 \%$ glycerin, $150 \mathrm{mM}$ Tris, $\mathrm{pH} 8.8$ and $2 \%(\mathrm{w} / \mathrm{v}$ ) idoacetamide) for again $20 \mathrm{~min}$.

\subsubsection{Second dimension}

After equilibration, IPG strips were loaded to the SDS-PAGE for separation of proteins into second dimension. The strips were horizontally placed on $12 \%$ SDS polyacrylamide gel $(0.375 \mathrm{M}$ Tris- $\mathrm{HCl}, \mathrm{pH} 8.8$ and $0.12 \%$ SDS and $0.025 \%$ TEMED and ammonium persulfate) and fixed with melted agarose $(0.5 \%, \mathrm{w} / \mathrm{v})$. The protein marker (Amersham, Freiburg, Germany) was also loaded on the gels and the gels were run at $100-400 \mathrm{~V}$ at $4^{\circ} \mathrm{C}$. At the end of the electrophoresis the gels were removed from the glass plates and either silver stained or stained with CBB.

\subsubsection{Coomassie Brilliant Blue (CBB) staining}

The CBB staining was carried out using $0.1 \%$ CBB (Roth, Karlsruhe, Germany) in the mixture containing methanol/acetic acid/water (40: 10: 50) for 24 hours. After that the gels were briefly destained using methanol/acetic acid/water (40:10:50) without CBB. The gels were stored in 5\% acetic acid in $\mathrm{ddH}_{2} \mathrm{O}$.

\subsubsection{Silver staining}

The gels were silver stained by using protocol described by (Blum et al. 1987). The gels were incubated on shaker in fixation solution $(50 \%$ methanol, $12 \%$ acetic acid in $\mathrm{ddH}_{2} \mathrm{O}$ ) for 1 hour following by twice washing with $50 \%$ ethanol and one washing with $30 \%$ ethanol each $20 \mathrm{~min}$. Sensitization was carried out for 60 second in sensitizing solution $\left(0.8 \mathrm{mM} \mathrm{Na}_{2} \mathrm{~S}_{2} \mathrm{O}_{3}\right.$ in $\left.\mathrm{ddH}_{2} \mathrm{O}\right)$, following by three washing steps with $\mathrm{ddH}_{2} \mathrm{O}$ each for 20 second. The gels were then incubated with silver staining solution $\left(\mathrm{AgNO}_{3} \quad 0.2 \%\right.$ and $0.026 \%$ formaldehyde in $\left.\mathrm{ddH}_{2} \mathrm{O}\right)$ for $20 \mathrm{~min}$ followed by three washing steps with $\mathrm{ddH}_{2} \mathrm{O}$ each for 20 second. The incubation with developing solution $\left(6 \% \mathrm{Na}_{2} \mathrm{Co}_{3}, 0.0185 \%\right.$ formaldehyde, $16 \mu \mathrm{M} \mathrm{Na}_{2} \mathrm{~S}_{2} \mathrm{O}_{3}$ in $\left.\mathrm{ddH}_{2} \mathrm{O}\right)$ for 2-8 min 
brought the staining of spots. The developing reaction was stop by incubating the gels again with fixation solution for five min. The gels were stored in $5 \%$ acetic acid in $\mathrm{ddH}_{2} \mathrm{O}$.

\subsection{PROTEIN IDENTIFICATION BY MALDI-TOF MS}

The stained gel slices containing the protein were digested with trypsin. Trypsin cuts directly downstream of the two basic amino acids lysine $(K)$ and arginine $(R)$, which are fairly common residues. After complete digestion the cleaved protein will produce a set of peptides of varying masses, which are characteristic of that protein. After trypsin digestion, the protein fragments were extracted from the gels. The trypsindigested protein fragments were analyzed by Matrix-Assisted Laser Desorption/ionisation Time of Flight Mass Spectrometry (MALDI-TOF/MS) on a Voyager DE-STR (Applied Biosystems, CA,USA).

The sample to be analysed is dissolved in an appropriate volatile solvent, usually with a trace of trifluoroacetic acid (TFA) or formic acid. This protein sample is then mixed with an equal volume of a solution containing an excess of matrix. A range of compounds is suitable for use as matrices: sinapinic acid is a common one for protein analysis while a-cyano-4-hydroxycinnamic acid is often used for peptide analysis. An aliquot (1-2 $\mu$ l) of the final solution is applied to the sample target, which is allowed to dry prior to insertion into the high vacuum of the mass spectrometer. The laser shots, the energy arriving at the sample/matrix surface optimised, and data accumulated until a mass/charge spectrum of reasonable intensity has been gathered. The time-of-flight analyser separates ions according to their mass-tocharge $(\mathrm{m} / \mathrm{z})$ ratios by measuring the time it takes for ions to travel through a field free region known as the flight, or drift tube. The heavier ions are slower than the lighter ones. The $\mathrm{m} / \mathrm{z}$ scale of the mass spectrometer is calibrated with a known sample that can either be analysed independently (external calibration) or pre-mixed with the sample and matrix (internal calibration). 

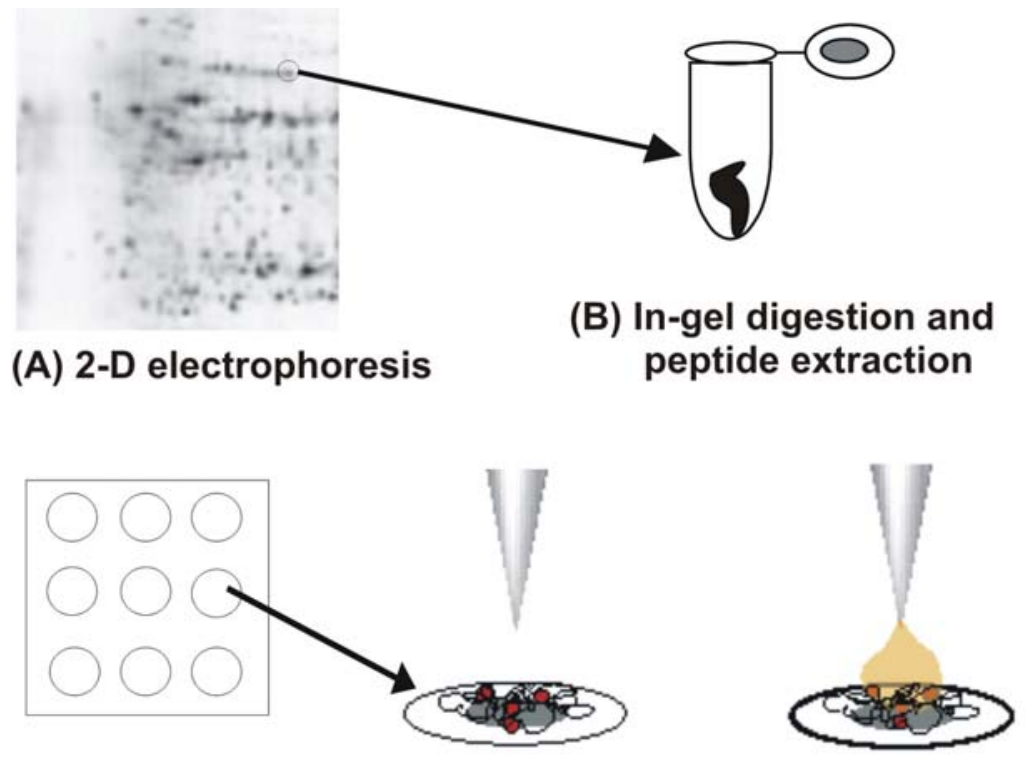

(C) Sample plate

(D) Sample application

(E) EAM application

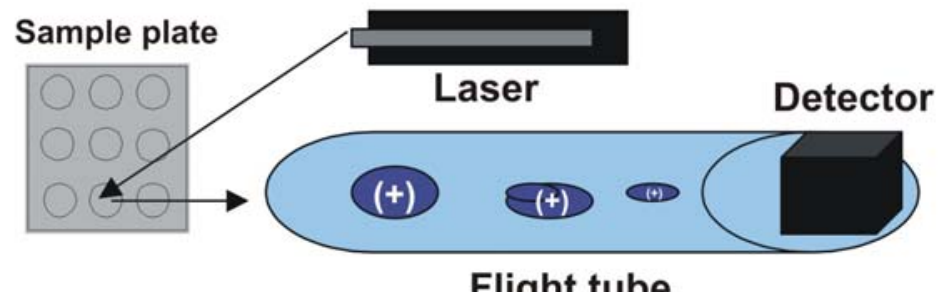

Flight tube

(F) MALDI-TOF measurement

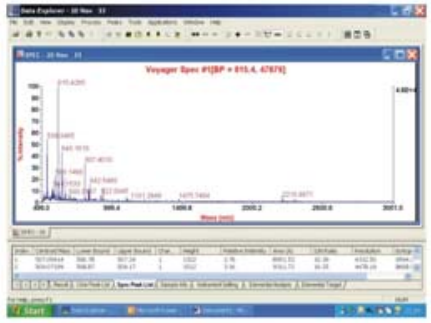

(G) Data out put

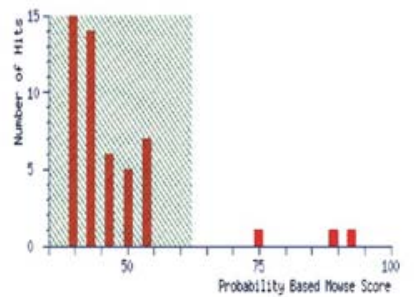

(G) Data base search result

Figure 3.1 The MALDI-TOF experimental procedure. The MALDI-TOF experimental procedure can be summarized in the following steps: (A) After sample preparation, separation of proteins in two dimensional electrophoresis (B) cutting the individual gel slices and in-gel digestion including extraction of digested protein fragments, ( $C$ and $D$ ) application of the protein fragments on sample plate $(E)$ application of energy absorbing molecules (EAM), ( $F$ and $G$ ) determination of mass ( $\mathrm{m} / \mathrm{z}$ ratio) of protein fragments by MALDI-TOF and its calibration by control peptides, $(\mathrm{H})$ The identification of protein by putting protein fragments masses on the internet based protein data bases. 


\subsubsection{In-gel digestion and preparation of proteins and proteolytic fragments for MALDI-TOF}

Before excising bands the gels were washed with $\mathrm{ddH}_{2} \mathrm{O}$ for $15 \mathrm{~min}$. Individual bands from CBB stained one dimension SDS gel or individual stained spots from 2D gel were chosen and carefully excised by using clean scalpel. Each gel slice was cut into small pieces and putt into the separate $0.5 \mathrm{ml}$ sterile tubes. The in-gel-digestion of the proteins were performed similar to that described by Dihazi (Dihazi et al. 2001) with some modifications. The silver stained bands were first destained by using Silver destaining kit (Invitrogen) until decolorized and after washing, directly proceed to the trypsin digestion stage.

The CBB stained gel pieces were decolorized by washing with $100 \mu \mathrm{ddH}_{2} \mathrm{O}$ for 15 min. The $d_{d d} \mathrm{H}_{2} \mathrm{O}$ was then pulled off and $40 \mu \mathrm{l}$ of $1: 1$ acetonitrile $(\mathrm{ACN}) / \mathrm{ddH}_{2} \mathrm{O}$ was added and incubated for $15 \mathrm{~min}$. After sucking off the solution, $40 \mu \mathrm{l}$ of ACN was added and incubated until gel pieces became white and sticky. The solution was discarded and $40 \mu \mathrm{l}$ of $100 \mathrm{mM}$ ammonium bicarbonate (Ambic) was added and incubated for $5 \mathrm{~min}$. After that $40 \mu \mathrm{l}$ of $\mathrm{ACN}$ was added to make 1:1 solution and again incubated $15 \mathrm{~min}$. The solution was then sucked off and samples were fully dried down by speed centrifugation.

Trypsin digestion was performed by adding $40 \mu$ or more (enough to cover pieces) of trypsin digestion solution $\left(5 \mu \mathrm{l} 1 \mathrm{M} \mathrm{CaCl}_{2}, 50 \mu \mathrm{l} \mathrm{M} \mathrm{Ambic,} 945 \mu \mathrm{ddH}_{2} \mathrm{O}\right.$, and 10 $\mathrm{ng} / \mu \mathrm{l}$ Trypsin) and incubated $45 \mathrm{~min}$ on ice. More solution was added if pieces absorbed all of the solution. At the end of incubation, the solution was sucked off and 40-60 $\mu \mathrm{l}$ of digestion buffer without trypsin was added and incubated overnight at $37^{\circ} \mathrm{C}$. At the end of incubation period, the digestion was acidified by using $10 \mu \mathrm{l}$ of $2 \%$ trifluoroacetic acid (TFA) in water. After 1-2 min of incubation, the supernatant was removed and saved in a separate $0.5 \mathrm{ml}$ tube. The gel slices were again covered by $20-50 \mu \mathrm{l}$ of $0.1 \%$ TFA in water and were placed in a floating rack in a sonication water bath and extracted for $30 \mathrm{~min}$ by sonication. The supernatant was pulled off and added in the previous stock supernatant. The same procedure was repeated with, $30 \% \mathrm{ACN}+70 \% 0.1 \% \mathrm{TFA}$, and $60 \% \mathrm{ACN}+40 \% 0.1 \% \mathrm{TFA}$. At the end, pooled supernatants were vacuum-centrifuged to remove TFA/ACN until dry. The protein dry pellet was stored at $-20^{\circ} \mathrm{C}$ until analysis.

\subsubsection{Matrix Solution Preparation}

The matrix solutions were prepared by adding solid $\alpha$-cyano-4-hydroxycinnamic acid to the organic solvent $(50 \% \mathrm{ACN}$ in high grade water) to saturation. The mixture was vortexed and centrifuged until a clear matrix solution was prepared. 


\subsubsection{Sample-Matrix Crystallization}

For analysis $10 \mu \mathrm{l}$ of formic acid was added to the dried protein pellet and was mixed by vortexing. Two $\mu \mathrm{l}$ of the protein solution was mixed with the same volume of matrix solution. An $1.5 \mu \mathrm{l}$ aliquot of sample-matrix solution was deposited onto a stainless steel 100 sample MALDI target plate and complete tried at room temperature.

\subsubsection{MALDI-TOF Mass Spectrometry}

MALDI mass spectra were acquired on a Voyager DE-Pro MALDI-TOF mass spectrometer operated in reflector mode. Ions were accelerated by $20 \mathrm{kV}$ after an extraction delay time of 200 ns. MALDI-TOF mass spectra was a signal average of 50-100 laser shots and mass-calibrated using a four-point external calibration The instrument was calibrated with signals of the positive $[\mathrm{MH}+]$ ion of bradykinin (904.468 Da), angiotensin I (1296.685 Da), Glu 1-fibrinopeptide B (1570.677 Da), adrenocorticotropic hormone (1-17) (2093.086 Da) and adrenocorticotropic hormone (18-39) (2465.198 Da). The final peptide masses were calibrated with Data Explorer Voyager V 5.0 (Applied Biosystems). The final peptide mass values obtained after analysis of in-gel tryptic digests were put into the Internet tools: Moscot (www.matrixscience.com). The 65\% significance was considered optimal for protein identification.

\subsection{SELDI-TOF MASS SPECTROMETRY}

The differential protein expression under the influence of forskolin and DHEAS stimulation was carried out using TCL, TCM and cytosol fractions of $\mathrm{NCl}-\mathrm{H} 295 \mathrm{R}$ cells with the help of surface enhanced laser desorption ionisation time of flight mass spectrometry (SELDI-TOF). The major SELDI operation could be described in four parts: The first step is capture or "dock" one or more proteins of interest on the ProteinChip $®$ Array, directly from the original source material, without sample preparation and without sample "labelling". The second enhance the "signal-to-noise" ratio by reducing chemical and biomolecular "noise" (i.e. achieve selective retention of target on the chip by washing away undesired materials). The third is an addition of the energy-adsorbing molecule (EAM) called as matrix i.e. sinapinic acid. The fourth step is reading the chips by mass reader. In this step the bound proteins are liberated by ionization, and fly through a "time-of-flight" tube where they separate the 
protein based on mass-to-charge ratio. The ProteinChip $®$ Software converts the TOF data to generate a mass spectrum profile. The hydrophobic $\mathrm{H} 50$ ProteinChip $\circledast 8$ spot array was used in the present study. The simplified SELDI-TOF process is described in figure (3.2).

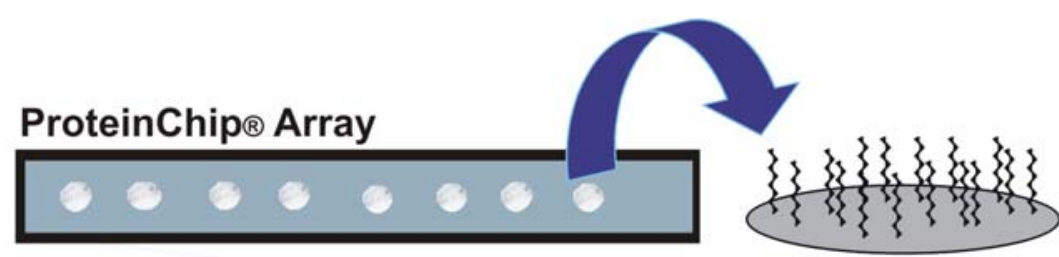

1- Surface preactivation

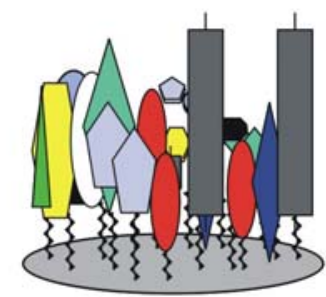

2- Sample capture

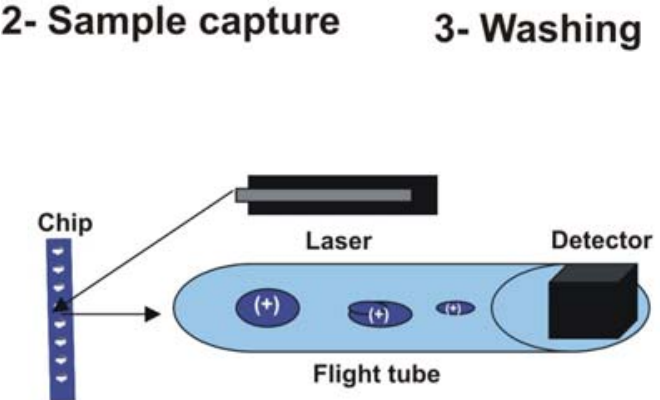

5- SELDI reader

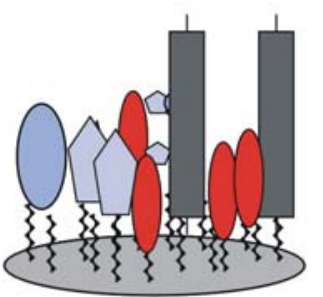

3- Washing

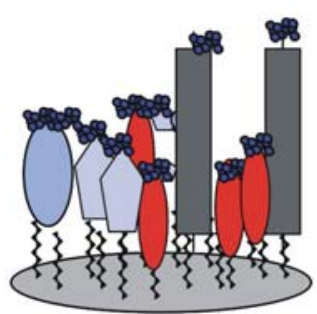

4- EAM application

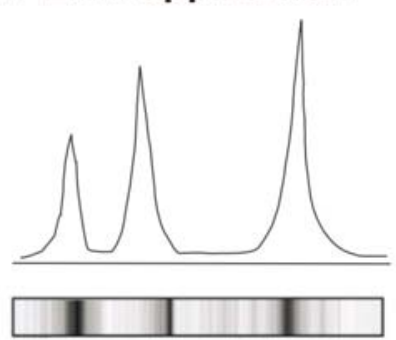

6- Output

(raw spectra \& gel view)

Figure 3.2 The SELDI-TOF experimental procedure. A simplified SELDI procedure includes (1) the activation of 8 spot ProteinChip $®$ by series of washing steps, (2) application of sample and incubation for certain period, (3) 3-5 washing steps to remove unwanted proteins, (4) application of energy absorbing molecules (EAM), (5) Reading the chip bound proteins by SELDI Reader, and (6) computer based interpretation of the data using ProteinChip ${ }^{\circledR}$ Reader Software. The data can be seen in raw spectra as well as in gel view format.

\subsubsection{H-50 ProteinChip $®$ preparation and analysis by SELDI-TOF}

The TCL, TCM and cytosol fraction of control (non-stimulated), forskolin or DHEA sulfate stimulated cells was dissolving in Reha buffer and centrifugation at 14,000 rpm for $15 \mathrm{~min}$. The supernatant was applied on ProteinChip ${ }^{\circledR}$ by following procedure.

The chips were washed three times with $1 \%$ TFA for $10 \mathrm{~min}$. The one volume of supernatant was diluted with three volumes of 1\% TFA (1:3). The $100 \mu \mathrm{l}$ of sample/TFA solution was applied on each chip spot and incubated for one hour at 
gentle shaking motion for binding. The Protein $C h i p \AA$ were then washed twice with $1 \%$ TFA for 10 min to eliminate the unbinded sample and extra salts. After that the chips were completely dried at RT. One microlitre matrix (sinapinic acid saturated solution almost $5 \mathrm{mg} / \mathrm{ml}$ ) per spot was applied and dried at RT. A second application of matrix was done and dried again at RT. At complete dryness, ProteinChip $®$ Reader analysed the chips under the following settings: Laser intensity 240 , detector sensitivity 10 , molecular mass range $0-25,000 \mathrm{Da}$ and a 50 -shots average per sample. The data was collected and used in later analysis by ProteinChip $®$ Reader software V 3.0. 


\section{RESULTS}

\subsection{CORTISOL RELEASE FROM NCI-H295R CELLS}

The $\mathrm{NCl}-\mathrm{H} 295 \mathrm{R}$ cell line was derived from a female with adrenocortical carcinoma tumor. This is the only cell line so far producing a full range of glucocorticoids, mineralcorticoids and C19 steroids. First of all we checked for the abilities of the cell line for cortisol production with and without different stimuli. In control experiments the cortisol secretion was significantly measurable after $6 \mathrm{~h}$ in the incubation medium. Initially, we examined the effects of ACTH and forskolin treatment on NClH295R cells for cortisol release. The cells grown in 6 well plates were incubated with ACTH or forskolin and control without stimuli for 6 h, 12 h, 24 h or 48 h. After the incubation period, the supernatant medium was collected and assayed for cortisol contents. The results were standardized to pmol cortisol /mg protein by measuring the protein concentration of each well. Although the rate of cortisol secretion in response to $\mathrm{ACTH}$ and forskolin varied considerably among cultures, the stimulation of secretion was significant in each culture.

\subsubsection{ACTH stimulated cortisol release from NCl-H295R cells}

Secretion of cortisol from $\mathrm{NCl}-\mathrm{H} 295 \mathrm{R}$ cells increased with time $(6 \mathrm{~h}, 12 \mathrm{~h}, 24 \mathrm{~h}$, and $48 \mathrm{~h}$ to $19.3 \pm 1.1,29.6 \pm 1.1,39.6 \pm 2.6$, and $69.6 \pm 6.6 \mathrm{pmol} / \mathrm{mg}$ protein, respectively (Fig. 4.1 white bars). Treatment of $\mathrm{NCl}-\mathrm{H} 295 \mathrm{R}$ cells with $10 \mathrm{nM}$ or $20 \mathrm{nM}$ ACTH over six hours showed no significant increase in cortisol secretion: $17.7 \pm 1.0$ $\mathrm{pmol} / \mathrm{mg}$ protein, and $22.9 \pm 1.6 \mathrm{pmol} / \mathrm{mg}$ protein, ACTH stimulated versus nonstimulated cells $(19.3 \pm 1.1 \mathrm{pmol} / \mathrm{mg}$ protein) as indicated in figure 4.1 (gray and black bars). The $12 \mathrm{~h}$ incubation with $10 \mathrm{nM} \mathrm{ACTH}$ concentration had also no significant influence on the cortisol secretion (30.2 $\pm 2.5 \mathrm{pmol} / \mathrm{mg}$ protein), but $20 \mathrm{nM}$ $\mathrm{ACTH}$ induced a significant increase in cortisol release up to $44.2 \pm 4.7 \mathrm{pmol} / \mathrm{mg}$ protein $(\mathrm{P}<0.001)$. At $24 \mathrm{~h}$ and $48 \mathrm{~h}$ treatment, $10 \mathrm{nM} \mathrm{ACTH}$ evoked a significantly increased cortisol release $(65.5 \pm 8.3 \mathrm{pmol} / \mathrm{mg}$ protein; $\mathrm{P}<0.0001$, and $191.0 \pm 19.2$ $\mathrm{pmol} / \mathrm{mg}$ protein; $\mathrm{P}<0.0001$, respectively), over non-stimulated $\mathrm{NCl}-\mathrm{H} 295 \mathrm{R}$ cells. The stimulation of cells with $20 \mathrm{nM} \mathrm{ACTH}$ for 24 and $48 \mathrm{~h}$ did not result in a significantly higher cortisol release in comparison to $10 \mathrm{nM} \mathrm{ACTH}$ incubation. $20 \mathrm{nM}$ ACTH stimulated the cortisol secretion at $24 \mathrm{~h}$ and $48 \mathrm{~h}$ to $87.5 \pm 10.0 \mathrm{pmol} / \mathrm{mg}$ protein $(P<0.0001)$, and $159.4 \pm 27.9 \mathrm{pmol} / \mathrm{mg}$ protein $(P<0.01$, ) respectively. These data indicate that $\mathrm{ACTH}$ induced cortisol release in a time and concentration dependent manner. 


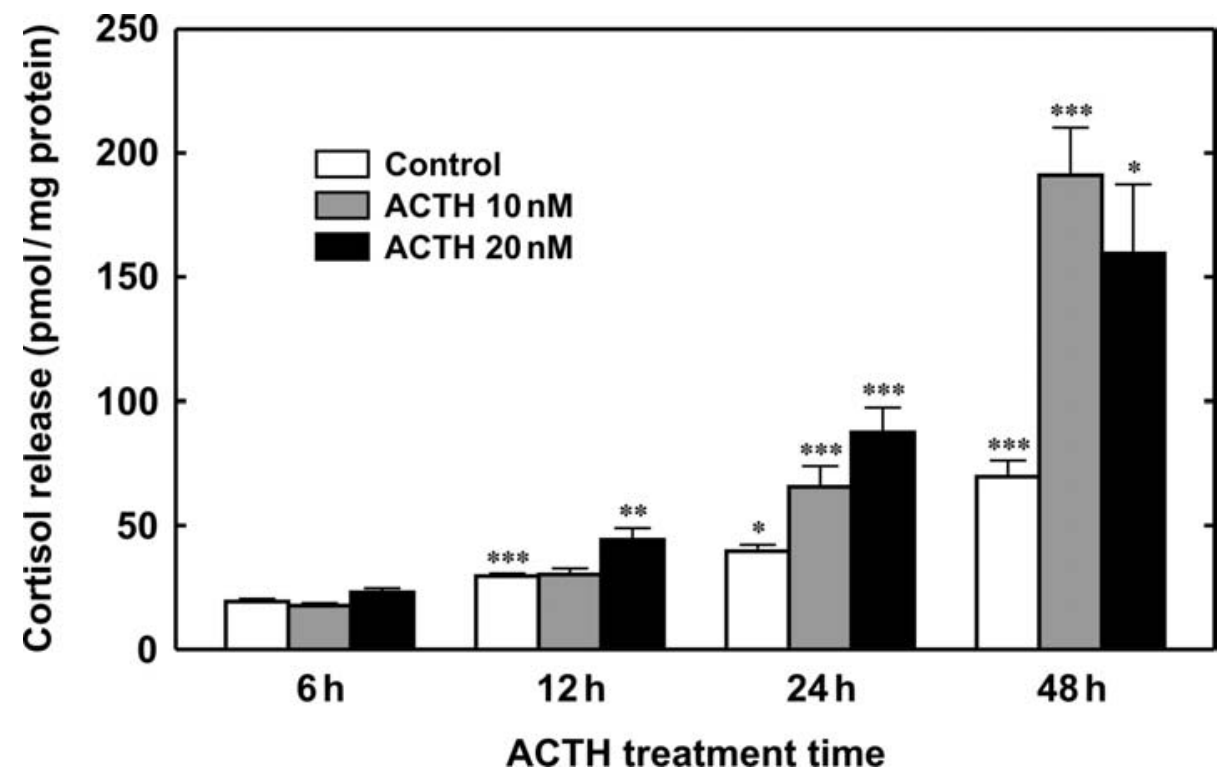

Figure 4.1 Time-dependent effect of ACTH on cortisol release by $\mathrm{NCl}-\mathrm{H} 295 \mathrm{R}$ cells. $\mathrm{NCl}-$ H295R cells were incubated for the time shown with $10 \mathrm{nM}$ ACTH or $20 \mathrm{nM}$ ACTH or without ACTH (control). The cortisol contents of the medium was determined by RIA and normalized to the protein concentration. Data points are means \pm SEM of values from six different experiments. The significance was calculated by student's t-test against the non-stimulated control $\left({ }^{*}, \mathrm{P}<0.01 ;{ }^{* *}, \mathrm{P}<0.001 ;{ }^{* * *}, \mathrm{P}<0.0001\right)$.

\subsubsection{Forskolin stimulated cortisol release from NCl-H295R cells}

After observing a stimulation of cortisol release by ACTH, we examined the effect of forskolin on cortisol release from $\mathrm{NCl}-\mathrm{H} 295 \mathrm{R}$ cells. Forskolin activates the adenylate cyclase that leads to elevate the CAMP concentration in cytosol. Cortisol release was increased more than 30 fold after $24 \mathrm{~h}$ treatment of $\mathrm{NCl}-\mathrm{H} 295 \mathrm{R}$ cells with $10 \mu \mathrm{M}$ forskolin in comparison to non-stimulated control cells. Forskolin produced significant elevation of cortisol release, 3 fold after 6 h, 4 fold after 12 h, 25 fold after 24 h, and 40 fold after $48 \mathrm{~h}$ (Figure 4.2). The absolute values for $10 \mu \mathrm{M}$ forskolin at $6 \mathrm{~h}, 12 \mathrm{~h}$, $24 \mathrm{~h}$, and $84 \mathrm{~h}$ were $61.0 \pm 6.3 \mathrm{pmol} / \mathrm{mg}$ protein $(\mathrm{P}<0.0001), 139.0 \pm 11.8 \mathrm{pmol} / \mathrm{mg}$ protein $(\mathrm{P}<0.0001), 976.7 \pm 80.8 \mathrm{pmol} / \mathrm{mg}$ protein $(\mathrm{P}<0.0001)$, and $2,922.7 \pm 496.4$ $\mathrm{pmol} / \mathrm{mg}$ protein $(\mathrm{P}<0.0001)$, respectively.

Cortisol secretion of the $\mathrm{NCl}-\mathrm{H} 295 \mathrm{R}$ cells at $6 \mathrm{~h}, 12 \mathrm{~h}, 24 \mathrm{~h}$, and $48 \mathrm{~h}$ after treatment with $20 \mu \mathrm{M}$ forskolin was stimulated by more than 3 fold to $45.8 \pm 1.9 \mathrm{pmol} / \mathrm{mg}$ protein $(P<0.0001), 5$ fold to $147.9 \pm 20.2 \mathrm{pmol} / \mathrm{mg}$ protein $(P<0.0001), 43$ fold to $1,681 \pm 123 \mathrm{pmol} / \mathrm{mg}$ protein $(P<0.0001)$, and 52 fold to $3,589 \pm 327 \mathrm{pmol} / \mathrm{mg}$ protein $(P<0.0001)$ respectively, as is shown in figure $4.2(A)$, in comparison to nonstimulated $\mathrm{NCl}-\mathrm{H} 295 \mathrm{R}$ cells. 
We also checked whether the observed cortisol secretion by $\mathrm{NCl}-\mathrm{H} 295 \mathrm{R}$ cells remains elevated after changing forskolin-containing medium by normal medium without forskolin. For this purpose cells were preincubated $24 \mathrm{~h}$ with $10 \mu \mathrm{M}$ or $20 \mu \mathrm{M}$ forskolin and then washed three times with warm PBS. Cells were then incubated in medium without forskolin. After $24 \mathrm{~h}$ the cortisol secretion was measured. Cortisol secretion remained high at both preincubation concentrations of $10 \mu \mathrm{M}$ up to $821.3 \pm$ $296.5 \mathrm{pmol} / \mathrm{mg}$ protein $(\mathrm{P}<0.0001)$ (Fig. $4.2 \mathrm{~B}$ gray bar) and of $20 \mu \mathrm{M}$ up to $1,389.0$ $\pm 198.4 \mathrm{pmol} / \mathrm{mg}$ protein $(\mathrm{P}<0.0001)$ (Fig. $4.2 \mathrm{~B}$ black bar) at $24 \mathrm{~h}$ after removal of the forskolin containing medium with reference to not pre-stimulated control $(39.6 \pm$ $2.5 \mathrm{pmol} / \mathrm{mg}$ protein).

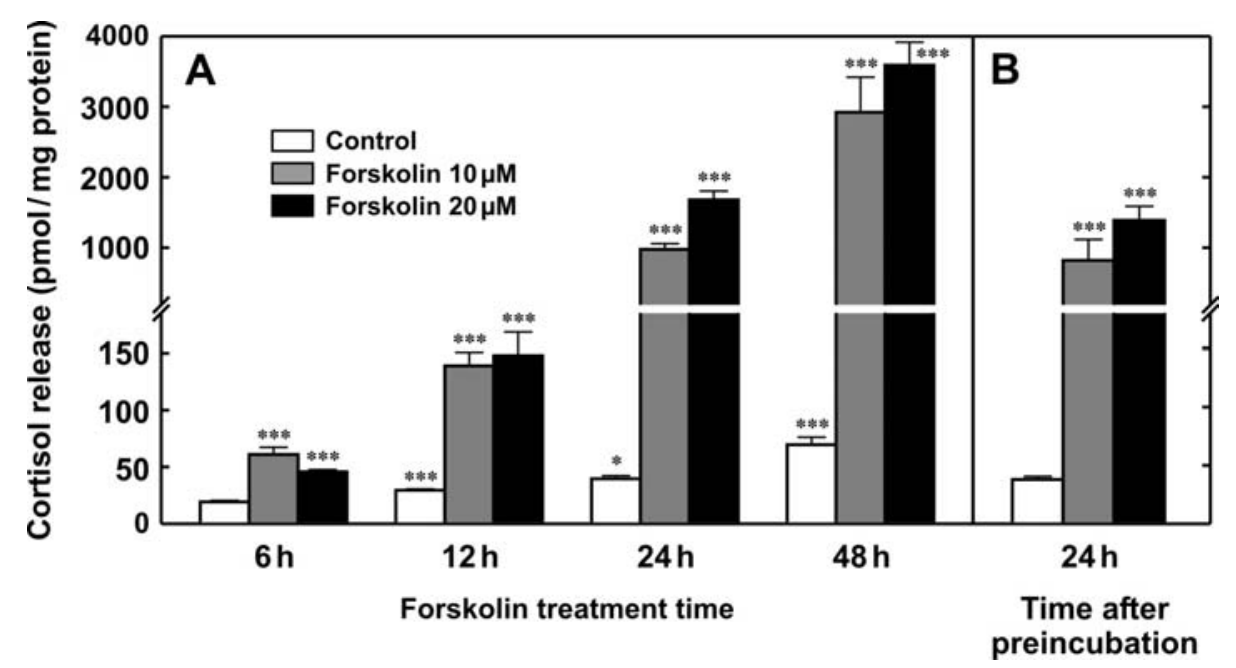

Figure 4.2 Time-dependent effect of forskolin on cortisol release by NCI-H295R cells. $\mathrm{NCl}-\mathrm{H} 295 \mathrm{R}$ cells were incubated for the time shown with (A) $10 \mu \mathrm{M}$ or $20 \mu \mathrm{M}$ forskolin, or without forskolin (control). The cortisol content of the medium was determined by RIA and normalized to the protein concentration. Data points are means \pm SEM of values from six different experiments. (B) The cells were pre-stimulated for $24 \mathrm{~h}$ with $10 \mu \mathrm{M}$ or $20 \mu \mathrm{M}$ forskolin. After washing with PBS, the cells were incubated with medium without forskolin for the $24 \mathrm{~h}$ time. Data points are the means \pm SEM of values from three different experiments. The significance was calculated by student's t-test against the non-stimulated control $\left({ }^{*}, \mathrm{P}<\right.$ $\left.0.01 ;{ }^{* *}, \mathrm{P}<0.001 ;{ }^{* * *}, \mathrm{P}<0.0001\right)$. 


\subsection{INHIBITION OF CORTISOL RELEASE FROM NCI- H295R CELLS}

The involvement of OATs in cortisol release has been tested so far in bovine and rat, but not in human adrenals. We investigated the inhibition of cortisol release from $\mathrm{NCl}-\mathrm{H} 295 \mathrm{R}$ cells by probenecid, a potent inhibitor of OAT family, and by PAH and glutarate, model substrates of OAT1. The cells were pre-stimulated for $24 \mathrm{~h}$ with 10 $\mu \mathrm{M}$ forskolin. After washing the cells with warm PBS, cells were incubated with medium containing $10 \mu \mathrm{M}$ forskolin with or without inhibitory substances (probenecid or $\mathrm{PAH}$ or glutarate). At the end of $24 \mathrm{~h}$ incubation period, medium samples were collected to determine the inhibitory effect of the substances on the cortisol release. The rate of cortisol release in response to forskolin and the inhibition by different concentrations of test substances varied considerably among cultures. However, an inhibition of secretion was always visible.

\subsubsection{Inhibition of cortisol release by probenecid in NCl-H295R cells}

Probenecid inhibits the transport activity through OATs. In the presence of $0.25 \mathrm{mM}$

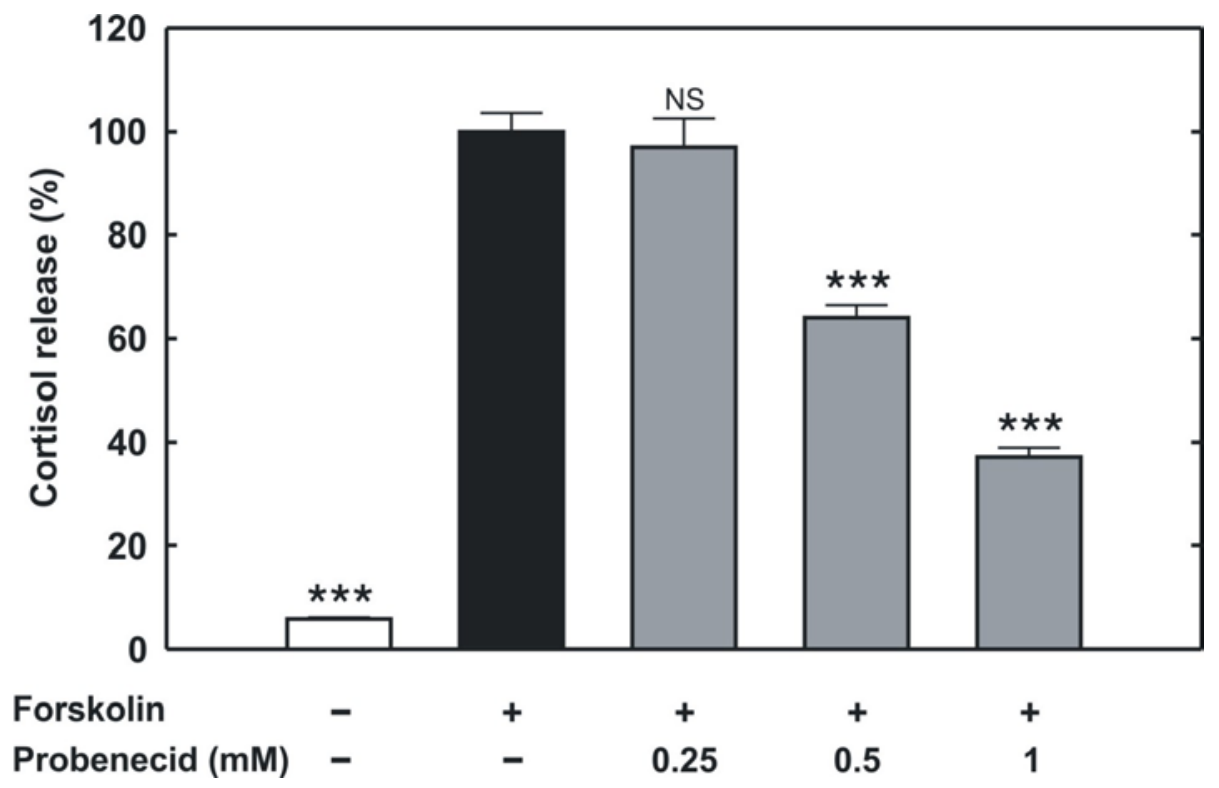

Figure 4.3 Concentration-dependent inhibition of cortisol release by probenecid in forskolin pre-stimulated $\mathbf{N C l}-\mathrm{H} 295 R$ cells. The cells were incubated for $24 \mathrm{~h}$ with $10 \mu \mathrm{M}$ forskolin, washed, and incubated again with medium containing $10 \mu \mathrm{M}$ forskolin, in the presence or absence of different concentrations of probenecid. The cortisol content of the medium was determined and normalized to the protein concentration. Data points are the means \pm SEM of values from four different experiments. Each column is calculated as a percentage of cortisol release in forskolin stimulated cells not exposed to probenecid. The significance was performed by student's t-test against control cells $\left({ }^{* * *}, \mathrm{P}<0.0001\right)$. 
probenecid, the cortisol release was $97.0 \pm 5.5 \%$, while $0.5 \mathrm{mM}$ and $1 \mathrm{mM}$ probenecid significantly inhibited the cortisol secretion to $64.0 \pm 2.4 \%(P<0.0001)$, and $37.1 \pm 1.8 \%(P<0.0001)$, respectively, compared to the forskolin stimulated control cells not exposed to probenecid $(100 \pm 2.6 \%)$ as shown in figure 4.3 .

\subsubsection{Inhibition of cortisol release by PAH in NCl-H295R cells}

PAH is a model substrate of several OATs. Inhibition of cortisol release by PAH was not effective at $0.01 \mathrm{mM}$ concentration, showing $100.5 \pm 2.6 \%$ as compared to forskolin stimulated control $\mathrm{NCl}-\mathrm{H} 295 \mathrm{R}$ cells (100 $\pm 2.6 \%)$. A significant reduction of cortisol secretion was observed by $0.1 \mathrm{mM}, 1 \mathrm{mM}$, and $5 \mathrm{mM}$ PAH concentrations, lowering the cortisol secretion to $72.4 \pm 5.1 \%(P<0.0001), 67.2 \pm 6.1 \%(P<0.0001)$, and $36.0 \pm 4.3 \%(P<0.0001)$, respectively, as compared to control $100 \% \pm 2.6 \%$ (Figure 4.4).

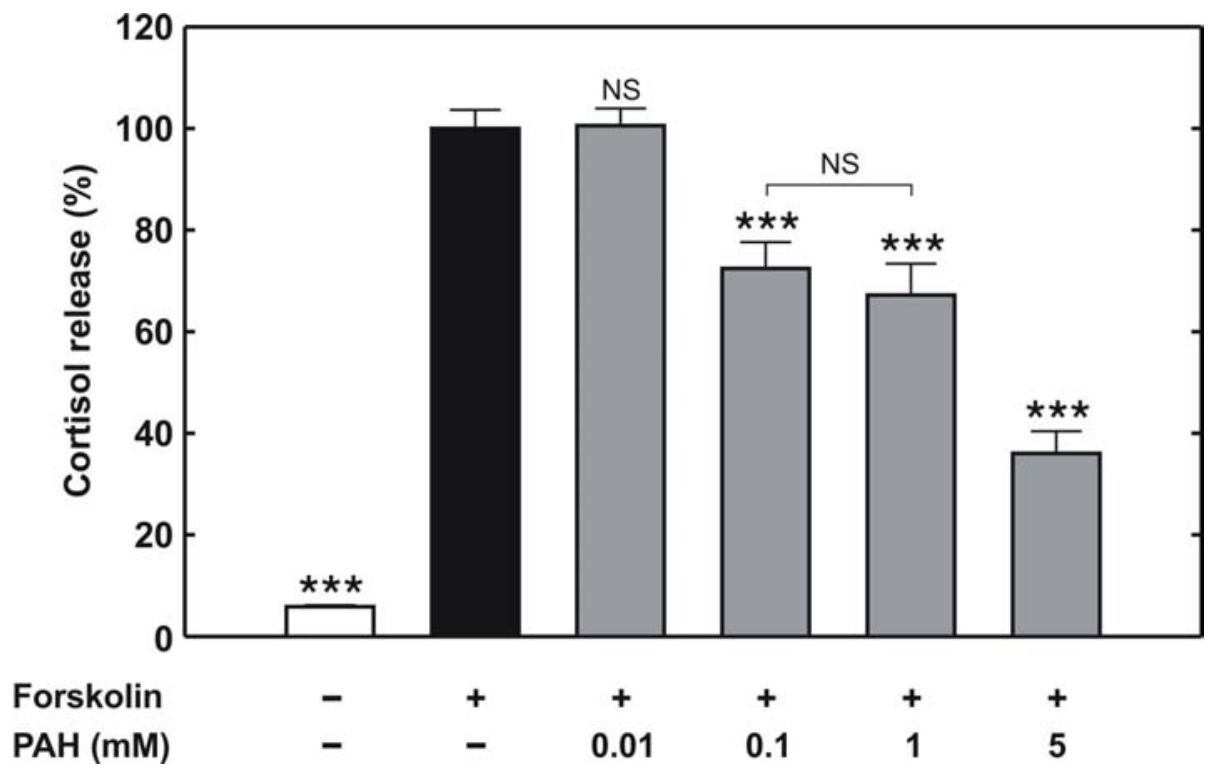

Figure 4.4 Concentration-dependent inhibition of cortisol release by PAH in forskolin pre-stimulated NCl-H295R cells. The cells were incubated for $24 \mathrm{~h}$ with $10 \mu \mathrm{M}$ forskolin, washed, and incubated again with medium containing $10 \mu \mathrm{M}$ forskolin, in the presence or absence of different concentrations of PAH. The cortisol content of the medium was determined and normalized to the protein concentration. Each column is calculated as a percentage value of cortisol release in forskolin stimulated cells not exposed to PAH. Data points are the means \pm SEM of values from four different experiments. The significance was performed by student's t-test against control cells $\left.{ }^{* * *}, P<0.0001\right)$. 


\subsubsection{Inhibition of cortisol release by glutarate in $\mathrm{NCl}-\mathrm{H} 295 \mathrm{R}$ cells}

OAT1 and OAT3 work in the exchanger mode (Bakhiya et al. 2003; Burckhardt et al. 2003). Both take up OA in exchange of dicarboxylates especially a-ketoglutarate. We checked the effect of glutarate on the cortisol secretion from the cells. At a concentration of $250 \mu \mathrm{M}$ glutarate inhibits $31 \%$ of the cortisol release from $\mathrm{NCl}$ $\mathrm{H} 295 \mathrm{R}$ cells i.e., the total uptake was reduced to $68.9 \pm 5.6 \%(P<0.001)$ as compared to the forskolin stimulated control $(100 \% \pm 2.6 \%)$

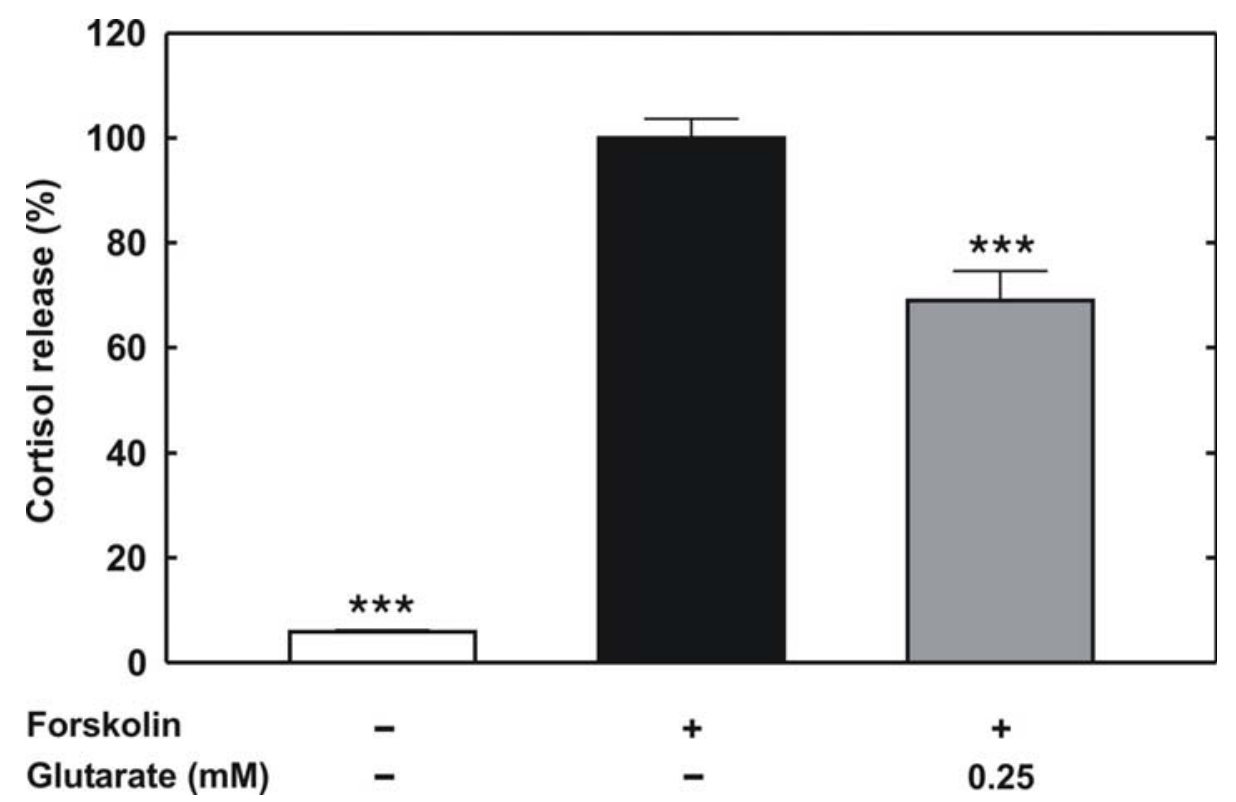

Figure 4.5 Inhibition of cortisol release by glutarate in forskolin pre-stimulated $\mathrm{NCl}$ H295R cells. The cells were incubated for $24 \mathrm{~h}$ with $10 \mu \mathrm{M}$ forskolin, washed, and incubated again with medium containing $10 \mu \mathrm{M}$ forskolin, in the presence or absence of different concentrations of glutarate. The cortisol content of the medium was determined by RIA and normalized to the protein concentration. Each column is calculated as a percentage value of cortisol release in forskolin stimulated cells not exposed to glutarate. Data points are the means \pm SEM of values from three different experiments. The significance was performed by student's t-test against control cells $\left.{ }^{* *}, \mathrm{P}<0.001\right)$.

\subsubsection{Inhibition of cortisol release by cimetidine in NCl-H295R cells}

The presence of $0.05 \mathrm{mM}$ cimetidine in the culture medium did not significantly reduce cortisol release from $\mathrm{NCl}-\mathrm{H} 295 \mathrm{R}$ cells (Figure 4.6). The inhibition of cortisol release by $0.1 \mathrm{mM}$ and $0.5 \mathrm{mM}$ was $8.7 \pm 5.9 \%(P<0.001)$ and $56.2 \pm 4.6 \%(P<$ $0.0001)$, respectively, as compared to forskolin stimulated control cells not exposed to cimetidine $(100 \%)$. 


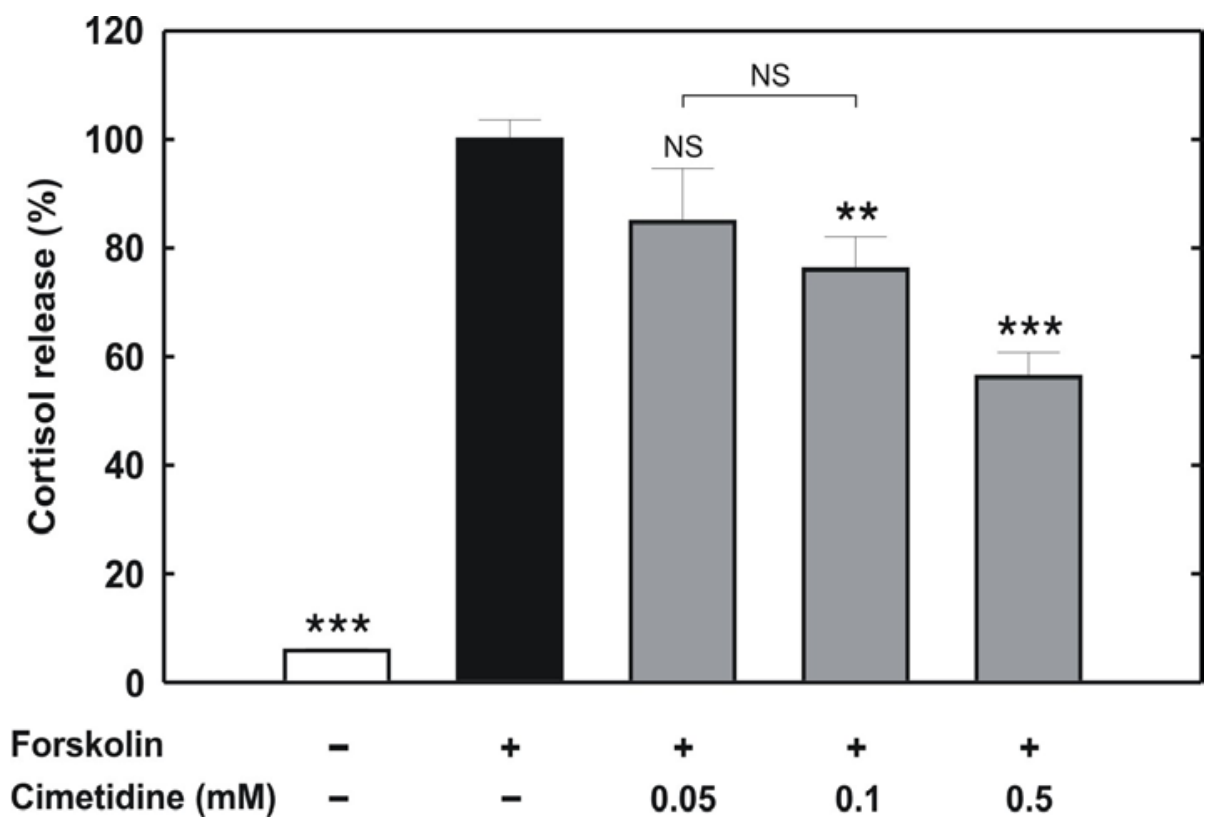

Figure 4.6 Concentration-dependent inhibition of cortisol release from forskolin prestimulated $\mathrm{NCl}-\mathrm{H} 295 \mathrm{R}$ cells by cimetidine. The cells were incubated for $24 \mathrm{~h}$ with $10 \mu \mathrm{M}$ forskolin, washed, and incubated again with medium containing $10 \mu \mathrm{M}$ forskolin, in the presence or absence of different concentrations of cimetidine. The cortisol content of the medium was determined and normalized to the protein concentration. Each column is calculated as a percentage value of cortisol release in forskolin stimulated cells not exposed to cimetidine. Data points are the means \pm SEM of values from two different experiments. The significance was performed by student's t-test against control cells $\left(^{* *}, \mathrm{P}<0.005 ;{ }^{* * *}, \mathrm{P}<\right.$ $0.0001)$.

\subsection{PAH UPTAKE BY NCI-H295R CELLS}

The experiments conducted with bovine primary cells showed $\left[{ }^{3} \mathrm{H}\right] \mathrm{PAH}$ uptake. This PAH uptake was inhibitable by probenecid and PAH (Steffgen et al. 1999). To clarify if the same transport operates in human adrenal cells, we performed radiolabeled $\mathrm{PAH}$ uptake in $\mathrm{NCl}-\mathrm{H} 295 \mathrm{R}$ cells.

\subsubsection{Time-course and temperature dependence of $\left[{ }^{3} \mathrm{H}\right] \mathrm{PAH}$ uptake into $\mathrm{NCl}-\mathrm{H} 295 \mathrm{R}$ cells.}

Initially, we checked the temperature dependency of [ $\left.{ }^{3} \mathrm{H}\right] \mathrm{PAH}$ uptake into $\mathrm{NCl}-\mathrm{H} 295 \mathrm{R}$ cells. The cells were incubated with $1 \mu \mathrm{M}\left[{ }^{3} \mathrm{H}\right] \mathrm{PAH}$ on ice and room temperature for different time intervals. The $\left[{ }^{3} \mathrm{H}\right] \mathrm{PAH}$ uptake into $\mathrm{NCl}-\mathrm{H} 295 \mathrm{R}$ cells at room temperature increases linearly until $20 \mathrm{~min}$. The uptake at different time intervals was 
at $10 \mathrm{~min}, 2.9 \pm 0.7 ; 20 \mathrm{~min} ; 7.2 \pm 0.9$; and at $30 \mathrm{~min}, 9.4 \pm 1.7 \mathrm{pmol} / \mathrm{mg}$ protein. The total $\left[{ }^{3} \mathrm{H}\right] \mathrm{PAH}$ uptake at $4^{\circ} \mathrm{C}$ (ice cold) was very low. At $10 \mathrm{~min}, 0.5 \pm 0.1 ; 20 \mathrm{~min}, 1.3$ \pm 0.2 ; and $30 \mathrm{~min}, 1.7 \pm 0.3 \mathrm{pmol} / \mathrm{mg}$ protein uptake was observed in experiments performed on ice.

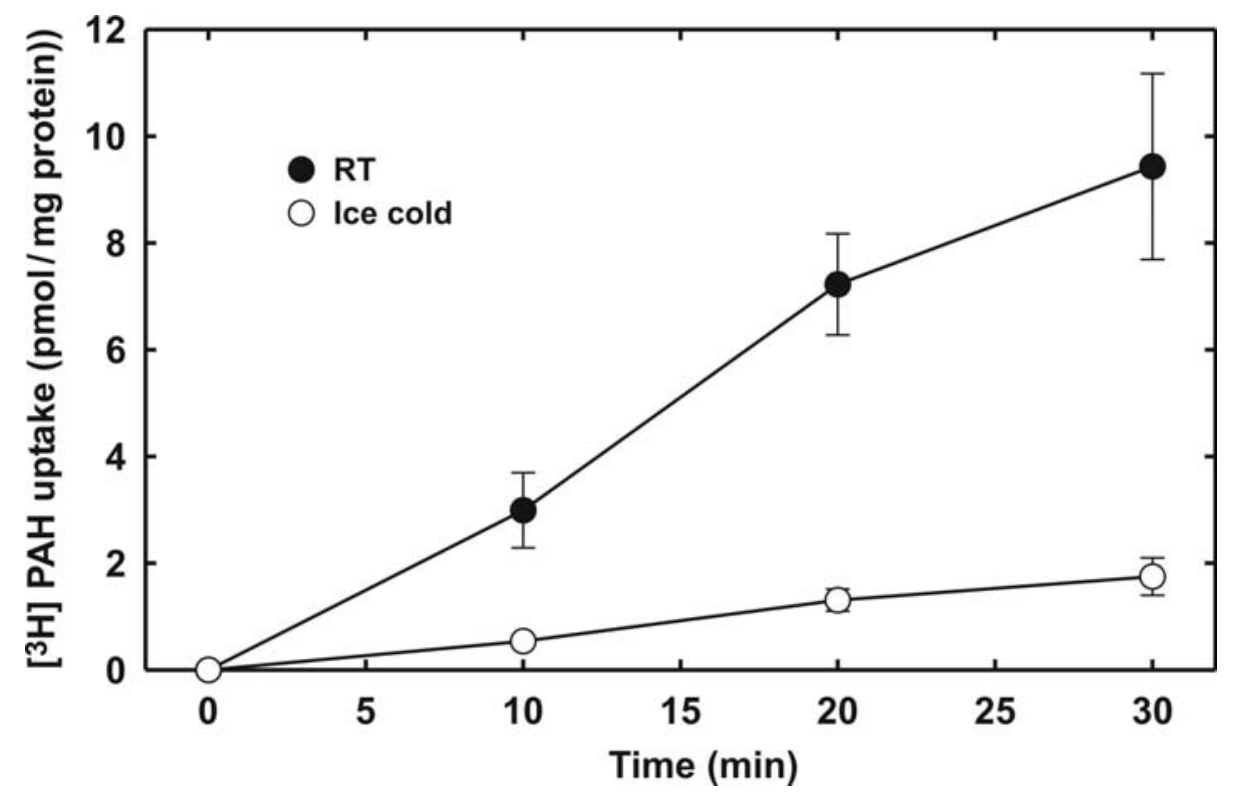

Figure 4.7 Time-course and temperature dependence of $\left[{ }^{3} \mathrm{H}\right] \mathrm{PAH}$ uptake into $\mathrm{NCI}-$ H295R cells The cells grown in 6-well plates were incubated for the indicated time periods with $\left[{ }^{3} \mathrm{H}\right] \mathrm{PAH}(5 \mu \mathrm{Ci} / \mathrm{ml}, 1 \mu \mathrm{M})$ at $\mathrm{RT}$ or on ice. The total radioactivity taken up by the cells was measured. Each point represents four independent experiments with 3 wells per condition. The data are means \pm SEM of all experiments.

\subsubsection{Forskolin stimulation of $\left[{ }^{3} \mathrm{H}\right] \mathrm{PAH}$ uptake}

We examined whether forskolin treatment could change the uptake of radiolabeled $\mathrm{PAH}$ into $\mathrm{NCl}-\mathrm{H} 295 \mathrm{R}$ cells. A $24 \mathrm{~h}$ treatment of $\mathrm{NCl}-\mathrm{H} 295 \mathrm{R}$ cells with forskolin increased PAH uptake by 1.38 fold over non-stimulated cells. The non-stimulated $\mathrm{NCl}-\mathrm{H} 295 \mathrm{R}$ cells showed a $\left[{ }^{3} \mathrm{H}\right] \mathrm{PAH}$ uptake of $72.3 \pm 3.4 \%(\mathrm{P}<0.0001)$ compared to cells $24 \mathrm{~h}$ pre-stimulated with forskolin $(100 \pm 2.1 \%)$. 


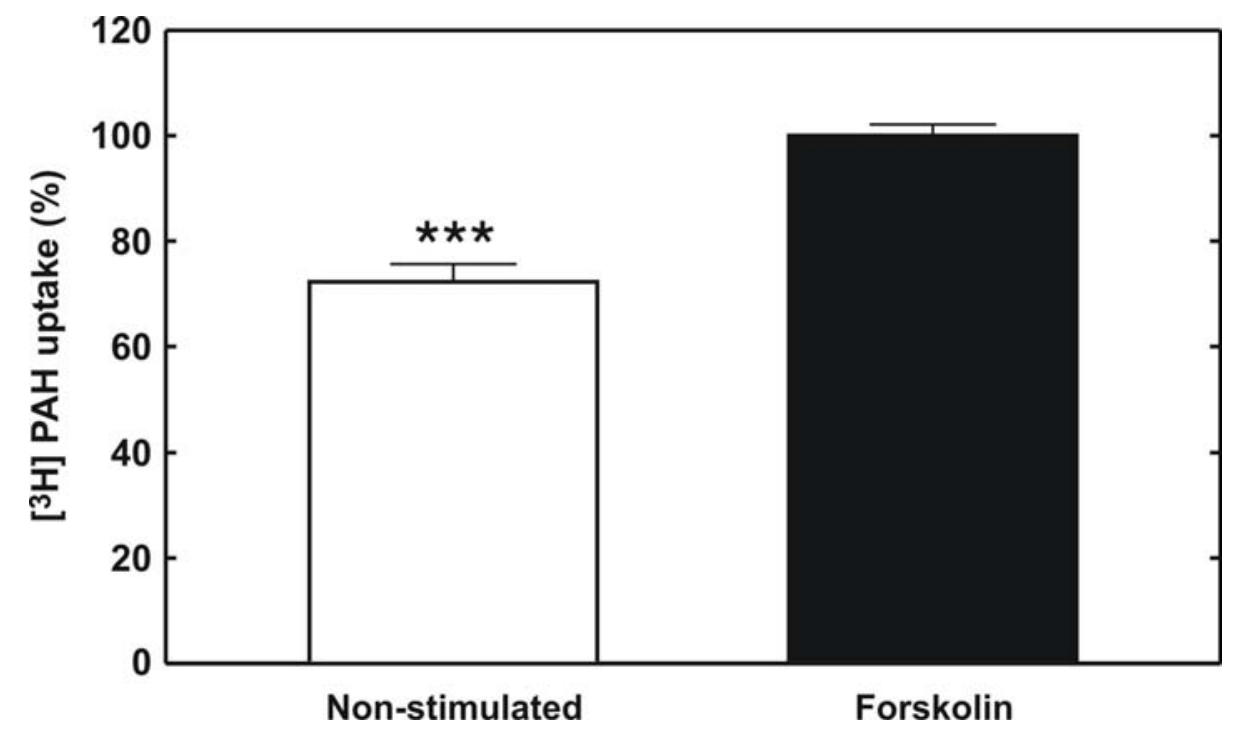

Figure 4.8 Effect of forskolin stimulation on $\left[{ }^{3} \mathrm{H}\right] \mathrm{PAH}$ uptake $\mathrm{NCI}-\mathrm{H} 295 \mathrm{R}$ cells. Cells grown in 6-well plates were either incubated for $24 \mathrm{~h}$ with medium containing $10 \mu \mathrm{M}$ forskolin or in medium without forskolin. At the end of incubation cells were washed, and incubated for $15 \mathrm{~min}$ with $5 \mu \mathrm{Ci} / \mathrm{ml}\left[^{3} \mathrm{H}\right] \mathrm{PAH}$. The uptake of $\mathrm{PAH}$ in non-stimulated cells was calculated as percentage of $\left[^{3} \mathrm{H}\right] \mathrm{PAH}$ uptake of forskolin pre-stimulated cells $(100 \%)$ within the same experiment. Data represent means \pm SEM of six independent experiments with 3 wells per condition. The significance was calculated by student's t-test against forskolin stimulated cells $\left.{ }^{* * *}, P<0.0001\right)$.

\subsubsection{Inhibition of $\left[{ }^{3} \mathrm{H}\right] \mathrm{PAH}$ uptake into $\mathrm{NCl}-\mathrm{H} 295 \mathrm{R}$ cells by probenecid}

Probenecid is a very potent inhibitor of human OAT family members and inhibits the uptake of organic anions. [ $\left.{ }^{3} \mathrm{H}\right] \mathrm{PAH}$ uptake by forskolin treated $\mathrm{NCl}-\mathrm{H} 295 \mathrm{R}$ cells was partially inhibited by probenecid. Probenecid at concentrations of $1 \mathrm{mM}, 2.5 \mathrm{mM}$ and $5 \mathrm{mM}$ reduced the $\left[{ }^{3} \mathrm{H}\right] \mathrm{PAH}$ uptake to $89.7 \pm 3.1 \%(\mathrm{P}<0.01), 69.0 \pm 4.8 \%(\mathrm{P}<$ $0.0001)$, and $45.6 \pm 10.1 \%(P<0.001)$, respectively, as shown in figure 4.9 . 


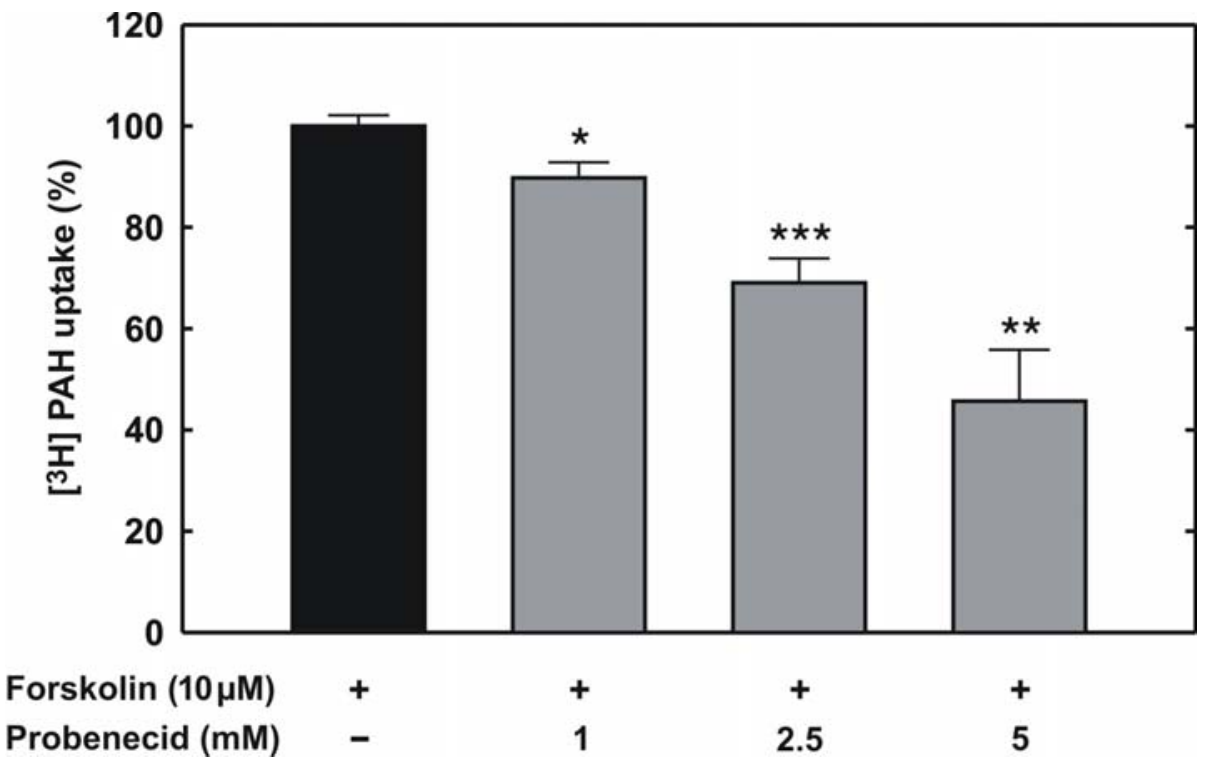

Figure 4.9 Effect of probenecid on $\left.{ }^{3} \mathrm{H}\right] \mathrm{PAH}$ uptake by forskolin pre-stimulated $\mathrm{NCl}$ H295R cells. The cells were incubated for $15 \mathrm{~min}$ with $\left[^{3} \mathrm{H}\right] \mathrm{PAH}(5 \mu \mathrm{Ci} / \mathrm{ml}, 1 \mu \mathrm{M})$, in the presence or absence of different concentrations of probenecid. Each column is calculated as percentage of $\left[^{3} \mathrm{H}\right] \mathrm{PAH}$ uptake of forskolin pre-stimulated cells $(100 \%)$ measured in the absence of probenecid within the same experiment. Data represent means \pm SEM of more then six independent experiments with 3 wells per condition in each experiment. The significance was calculated by student's t-test against the forskolin stimulated cells without probenecid ( $\left.{ }^{*}, \mathrm{P}<0.01 ;{ }^{* *}, \mathrm{P}<0.001 ;{ }^{* * *}, \mathrm{P}<0.0001\right)$.

\subsubsection{Inhibition of $\left[{ }^{3} \mathrm{H}\right] \mathrm{PAH}$ uptake into $\mathrm{NCI}-\mathrm{H} 295 \mathrm{R}$ cells by unlabeled PAH}

To check if the $\left[{ }^{3} \mathrm{H}\right] \mathrm{PAH}$ uptake into $\mathrm{NCl}-\mathrm{H} 205 \mathrm{R}$ cells is saturable, we added different concentrations of unlabeled $\mathrm{PAH}$ in the uptake medium. Unlabeled PAH reduced $\left[{ }^{3} \mathrm{H}\right] \mathrm{PAH}$ uptake slightly at concentrations of $1 \mathrm{mM}$ and $5 \mathrm{mM}$ to $87.6 \pm 3.8 \%(\mathrm{P}<$ $0.05)$, and $74.3 \pm 9.1 \%(P<0.01)$, respectively, as compared to control $(100 \%)$. 


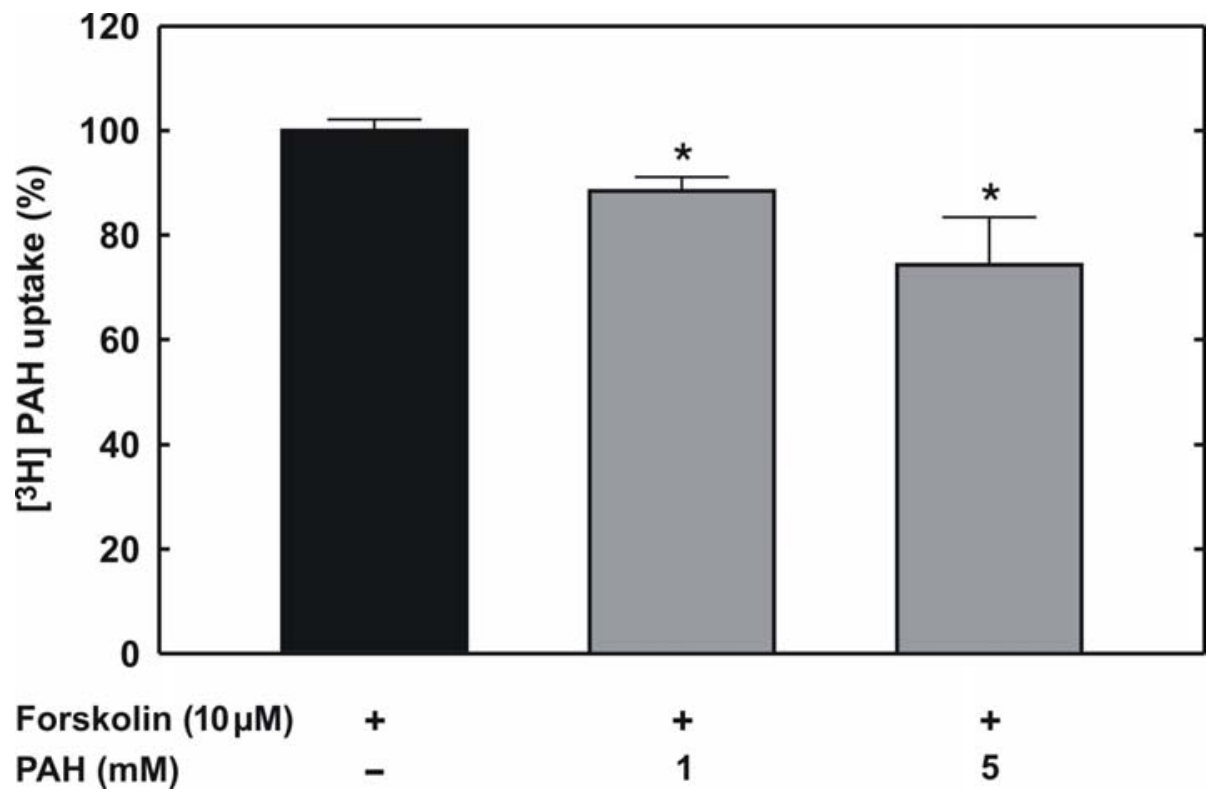

Figure 4.10 Effect of unlabeled $\mathrm{PAH}$ on $\left.{ }^{3} \mathrm{H}\right] \mathrm{PAH}$ uptake by forskolin pre-stimulated $\mathrm{NCI}-$ H295R cells. The cells were incubated for $15 \mathrm{~min}$ with $\left[{ }^{3} \mathrm{H}\right] \mathrm{PAH}(5 \mu \mathrm{Ci} / \mathrm{ml}, 1 \mu \mathrm{M})$, in the presence or absence of different concentrations of unlabeled $\mathrm{PAH}$. Each column is calculated as percentage of $\left[{ }^{3} \mathrm{H}\right] \mathrm{PAH}$ uptake of forskolin pre-stimulated cells $(100 \%)$ measured in the absence of unlabeled PAH within the same experiment. Data represent means \pm SEM of six independent experiments with 3 wells per condition in each experiment. The significance was calculated by student's t-test against the forskolin stimulated cells without unlabeled PAH ( ${ }^{*}, \mathrm{P}$ $<0.01)$.

\subsubsection{Inhibition of $\left[{ }^{3} \mathrm{H}\right] \mathrm{PAH}$ uptake by estrone sulfate into $\mathrm{NCl}-$ H295R cells}

Since estrone sulfate (ES) is a good substrate of hOAT3, OAT4 and many OATPs, we checked if ES could influence the $\left[{ }^{3} \mathrm{H}\right] \mathrm{PAH}$ uptake into these cells. The figure 4.11, illustrates a concentration dependent inhibition of $\left[{ }^{3} \mathrm{H}\right] \mathrm{PAH}$ uptake by unlabeled estrone sulfate. Ten microlitre estrone sulfate significantly reduced $\mathrm{PAH}$ uptake to $64.2 \pm 1.8 \%(P<0.001)$ compared to $100 \pm 2.1 \%$ control. The PAH uptake in the presence of $100 \mu \mathrm{M}$ and $500 \mu \mathrm{M}$ estrone sulfate was decreased to $52.1 \pm 2.5 \%$; $\mathrm{P}<$ 0.0001 and $46.6 \pm 2.1 \% ; P<0.0001$, respectively, (Figure 4.11). 


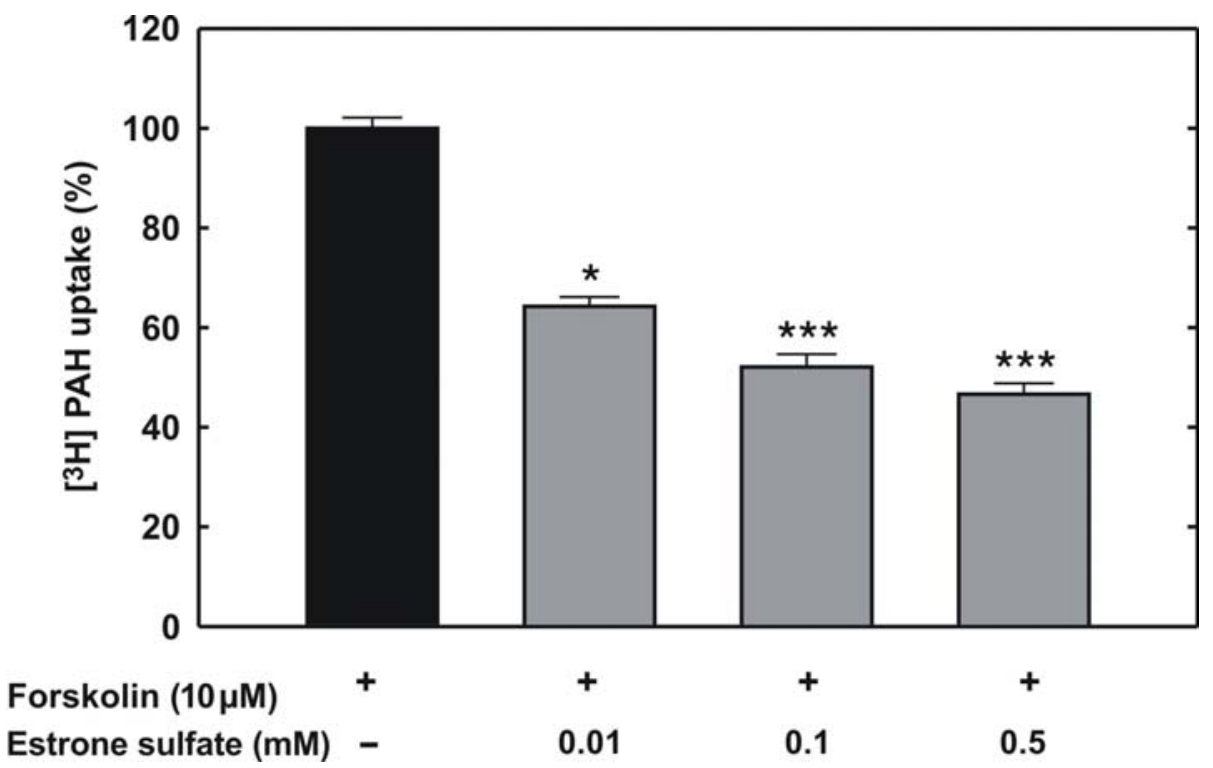

Figure 4.11 Effect of unlabeled estrone sulfate on $\left[{ }^{3} \mathrm{H}\right] \mathrm{PAH}$ uptake by forskolin prestimulated NCl-H295R cells. The cells were incubated for 15 min with $\left[{ }^{3} \mathrm{H}\right] \mathrm{PAH}(5 \mu \mathrm{Ci} / \mathrm{ml}, 1$ $\mu \mathrm{M})$, in the presence or absence of different concentrations of unlabeled estrone sulfate. Each column is calculated as percentage of $\left.{ }^{3} \mathrm{H}\right] \mathrm{PAH}$ uptake of forskolin pre-stimulated cells $(100 \%)$ measured in the absence of unlabeled estrone sulfate within the same experiment. Data represent means \pm SEM of two independent experiments with 3 wells per condition in each experiment. The significance was calculated by student's t-test against the forskolin stimulated cells without exposure to estrone sulfate $\left({ }^{*}, P<0.01\right)$.

\subsubsection{Trans-stimulation of $\left[{ }^{3} \mathrm{H}\right] \mathrm{PAH}$ uptake}

The OAT1 and OAT3 have been described to work in the exchanger mode, where they take up organic anion in exchange of some endogenous dicarboxylate i.e. $\alpha$ ketoglutarate (Bakhiya et al. 2003; Burckhardt et al. 2003). In order to clarify the function of OATs in the $\mathrm{NCl}-\mathrm{H} 295 \mathrm{R}$ cells, we performed radiolabeled PAH uptake in glutarate, $\mathrm{PAH}$ and cortisol preloaded cells. The $\mathrm{NCl}-\mathrm{H} 2945 \mathrm{R}$ cells grown in 24-well plates were preloaded either with $1 \mathrm{mM}$ glutarate, or $1 \mathrm{mM} \mathrm{PAH}$, or $100 \mu \mathrm{M}$ cortisol for 2 hours prior to the $\left[{ }^{3} \mathrm{H}\right] \mathrm{PAH}$ uptake in $\mathrm{NCl}-\mathrm{H} 295 \mathrm{R}$ cells. After extensively washing three times with pre-warmed Ringer solution, cells were incubated with $5 \mu \mathrm{Ci} / \mathrm{ml}$ $\left[{ }^{3} \mathrm{H}\right] \mathrm{PAH}$ for two min. At the end of the incubation period cells were washed with cold Ringer solution and the radioactivity taken up by the cells was measured.

The $\left[{ }^{3} \mathrm{H}\right] \mathrm{PAH}$ in $\mathrm{NCl}-\mathrm{H} 295 \mathrm{R}$ cells preloaded with unlabeled $\mathrm{PAH}$ was significantly higher than that into non-preloaded cells. The not preloaded control cells showed $70.1 \pm 4.7 \%$ as compared to preloaded cells with $\mathrm{PAH}: 100 \pm 2.9 \%(\mathrm{P}<0.0001)$. The 
simulated uptake was inhibited by presence of $500 \mu \mathrm{M}$ unlabeled glutarate to $76.2 \pm$ $7.0 \%(\mathrm{P}<0.001)$. When preloaded cells were incubated with $\left[{ }^{3} \mathrm{H}\right] \mathrm{PAH}$ in the presence of $50 \mu \mathrm{M}$ cortisol, the uptake was reduced to $69.3 \pm 3.5 \%(\mathrm{P}<0.0001)$, figure $4.12 \mathrm{~A}$.

The glutarate preloaded cells showed a significant higher $\left[{ }^{3} \mathrm{H}\right] \mathrm{PAH}$ uptake as compared to cells not preloaded with glutarate; $100 \pm 1.6 \%$ Vs $77.5 \pm 2.7 \%$ ( $P<$ 0.0001), respectively. When $500 \mu \mathrm{M}$ unlabeled glutarate was added to the uptake medium, the uptake was significantly reduced to $81.9 \pm 1.7 \%(P<0.0001)$. The presence of $50 \mu \mathrm{M}$ unlabeled cortisol in the uptake medium decreased the $\left[{ }^{3} \mathrm{H}\right] \mathrm{PAH}$ uptake to $69.6 \pm 6.4 \%$; $\mathrm{P}<0.0001$, (Figure $4.12 \mathrm{~B}$ ).

To check the effect of cortisol preloading, cells were incubated with $100 \mu \mathrm{M}$ unlabeled cortisol in the culture medium for 2 hours. After washing, the [ $\left.{ }^{3} \mathrm{H}\right] \mathrm{PAH}$ uptake was conducted in preloaded and in not preloaded control cells. We observed a slight but significant increased $\left[{ }^{3} \mathrm{H}\right] \mathrm{PAH}$ uptake in preloaded cells as compared to not preloaded control cells; $100 \pm 6.8 \%$ and $84.4 \pm 2.8 \%(P<0.05)$ respectively. This uptake remained unaffected by presence of $500 \mu \mathrm{M}$ glutarate in the uptake medium. When cortisol preloaded cells were incubated with [ $\left.{ }^{3} \mathrm{H}\right] \mathrm{PAH}$ containing $50 \mu \mathrm{M}$ cortisol in uptake medium, the radiolabeled uptake was reduced to $60.9 \pm 5.5 ; \mathrm{P}<0.0001$, figure $4.12 \mathrm{C}$.

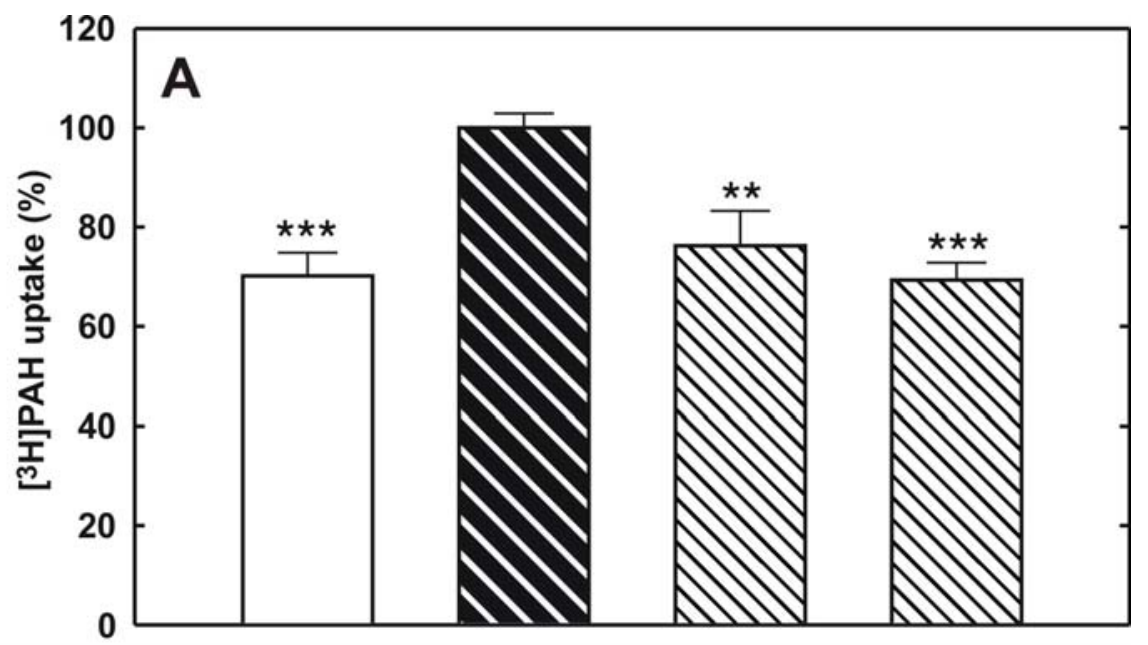

$\begin{array}{lllll}\text { PAH preloading } & - & + & + & + \\ \text { Glutarate }(500 \mu \mathrm{M}) & - & - & + & - \\ \text { Cortisol }(50 \mu \mathrm{M}) & - & - & - & +\end{array}$




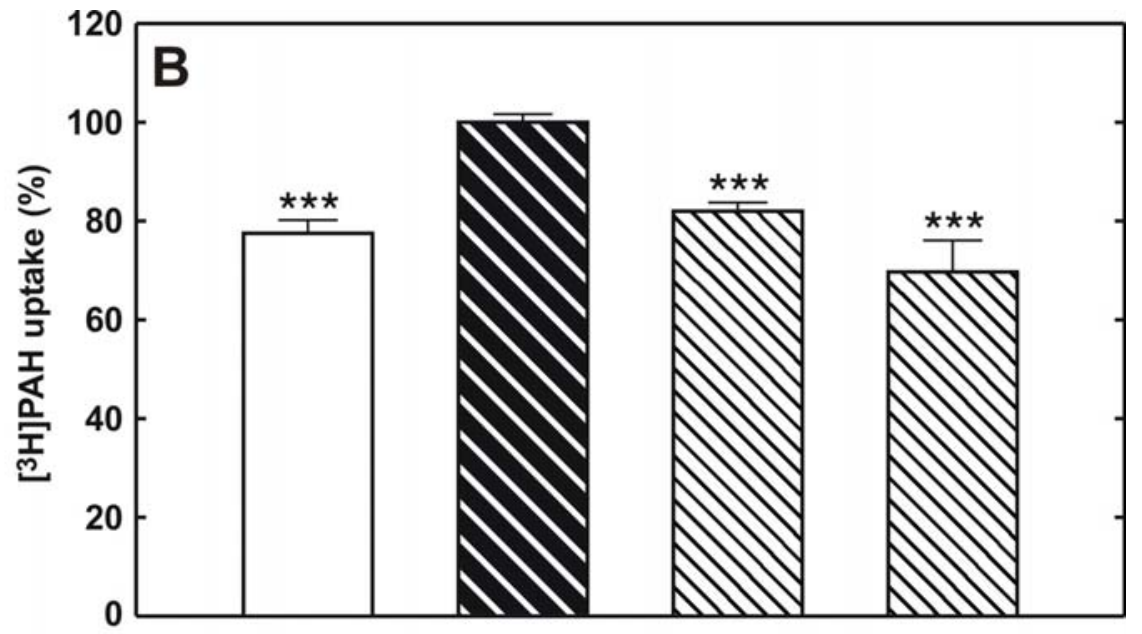

$\begin{array}{lllll}\text { Glutarate preloading } & - & + & + & + \\ \text { Glutarate }(500 \mu \mathrm{M}) & - & - & + & - \\ \text { Cortisol }(50 \mu \mathrm{M}) & - & - & - & +\end{array}$

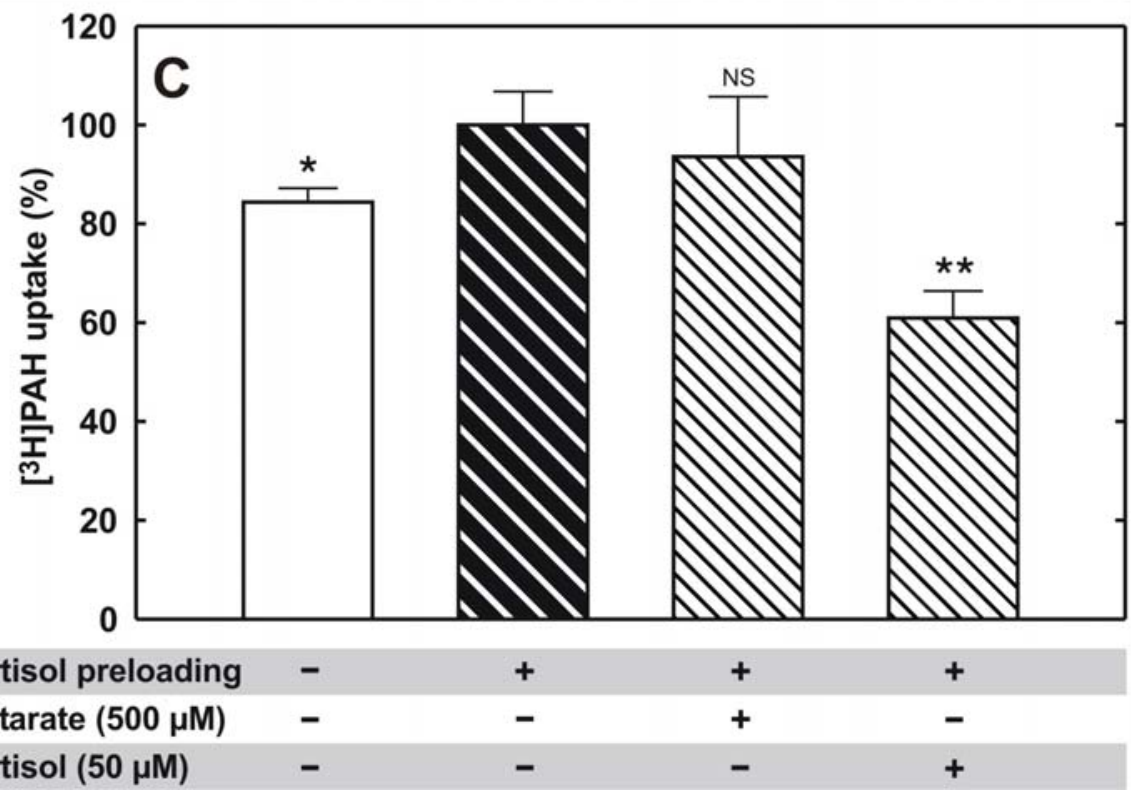

Figure 4.12 Trans-stimulation of $\left[{ }^{3} \mathrm{H}\right] \mathrm{PAH}$ uptake by glutarate, $\mathrm{PAH}$ and cortisol in NCIH295R cells. Cells were either preloaded with $1 \mathrm{mM}$ glutarate $(A)$, or $1 \mathrm{mM} P A H(B)$, or with $100 \mu \mathrm{M}$ cortisol (C), or with control medium without any additional substance for two hours prior to the uptake. After three washings, the cells were incubated for 2 min with $\left[{ }^{3} \mathrm{H}\right] \mathrm{PAH}$ ( 5 $\mu \mathrm{Ci} / \mathrm{ml}, 1 \mu \mathrm{M}$ ), in the presence of $500 \mu \mathrm{M}$ glutarate (column 3) or $50 \mu \mathrm{M}$ cortisol (column 4 ) or absence of any substance (column 1 and 2). Each column is calculated as percentage of $\left[^{3} \mathrm{H}\right] \mathrm{PAH}$ uptake by preloaded cells with $1 \mathrm{mM}$ glutarate $(\mathrm{A})$, or $1 \mathrm{mM} \mathrm{PAH}(\mathrm{B})$, or with $100 \mu \mathrm{M}$ cortisol (C) as (100\%) measured in the absence of glutarate, PAH and cortisol within the same experiment. Data represent means \pm SEM of three independent experiments with 3 wells per condition. The significance was calculated by student's t-test against the preloaded cells with $1 \mathrm{mM}$ glutarate $(\mathrm{A})$, or $1 \mathrm{mM}$ PAH (B), or with $100 \mu \mathrm{M}$ cortisol (C) without inhibitory substances in the uptake medium. 


\subsection{EXPRESSION OF HUMAN OATS, OATPS AND STEROID BIOSYNTHESIS ENZYMES MRNA IN NCI- H295R CELLS, HUMAN NORMAL AND TUMOR ADRENAL TISSUES}

To address the question, whether members of OAT family, OATP family and members of steroid biosynthesis enzymes family are expressed in the human adrenocortical cells, RT-PCR experiments were carried out on $\mathrm{NCl}-\mathrm{H} 295 \mathrm{R}$ cells, and a human normal and tumor adrenal tissue from a patient.

RNA extracted from the cells and human normal and tumor adrenal tissue was used to construct the cDNA, which was ultimately used to check mRNA expression of members of OAT, OATP and steroid biosynthesis enzymes families. The cloned plasmids of respective members of OAT and OATP families were used to test the PCR procedure. Specific primers were designed using the online (Rozen et al. 2000) primer design facility.

\subsubsection{Expression of OATs in NCl-H295R cells}

The specific amplification for hOAT1 and hOAT2 did not show any mRNA expression in $\mathrm{NCl}-\mathrm{H} 295 \mathrm{R}$, human normal, and tumor adrenal tissues. The validity of the PCR reaction and primer's specificity was confirmed by expected sizes of positive controls from human kidney cDNA and plasmid amplifications.

Human OAT3 and OAT4 specific primers reveal positive signals of their mRNA expression in $\mathrm{NCl}-\mathrm{H} 295 \mathrm{R}$ cells, normal and tumor adrenal tissues. The product sizes of the respective plasmids as well as from the $\mathrm{NCl}-\mathrm{H} 295 \mathrm{R}$ cells, normal and tumor adrenal tissues were of expected size. The PCR-product of hOAT3 and hOAT4 were confirmed by sequencing the fragments. 


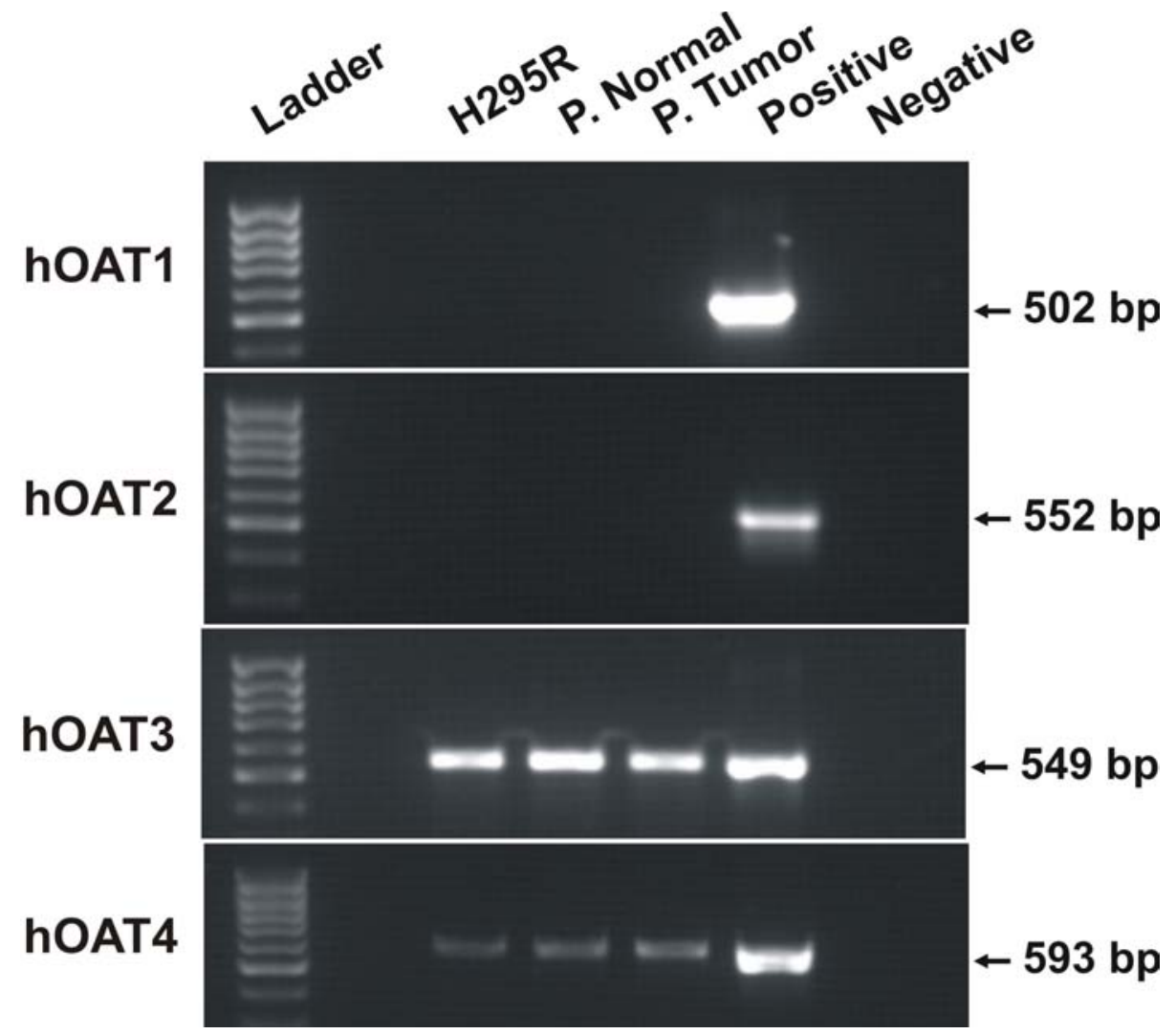

Figure 4.13 RT-PCR profiling of NCI-H295R cells, normal and tumor adrenal tissue for organic anion transporters. The cDNA from NCl-H295R cell line, normal and tumor adrenal tissue was used as a template, along with specific primers of hOAT1, hOAT2, hOAT3, and hOAT4 for PCR. The PCR from respective plasmids of hOAT1, hOAT2, hOAT3 and hOAT4 were used as standard positive control.

\subsubsection{Expression of OATPs in NCl-H295R cells}

Organic anion transporting polypeptides (OATP) are a group of carriers with a wide spectrum of amphipathic transport substrates (Meier et al. 1997) and are involved in hepatic clearance of albumin-bound compounds from portal blood. Since OATPs transport many steroid conjugates, we checked if members of OATP family are also expressed in adrenal glands and $\mathrm{NCl}-\mathrm{H} 295 \mathrm{R}$ cells. A series of sequence specific primers was designed for OATP-A, OATP-B, OATP-C and OATP-E.

The amplification of OATP-A revealed the expression in NCl-H295R cells, but no amplifications were found in normal and tumor adrenal tissues. The signals from NClH295R cells and positive clones were of expected size and were verified by subsequent sequencing the PCR products. NCl-H295R cells did not show any expression of OATP-B. In contrast, both human normal and tumor tissues showed strong signals. The product size was in line with that of the product from the positive 
control and was confirmed by sequencing. Therefore, both OATP-A and OATP-B are differently expressed either in $\mathrm{NCl}-\mathrm{H} 295 \mathrm{R}$ cells or in human adrenal tissues.

OATP-C and OATP-E specific primers did not reveal any positive signal, neither in $\mathrm{NCl}-\mathrm{H} 295 \mathrm{R}$ cells nor in adrenal normal or tumor tissue.

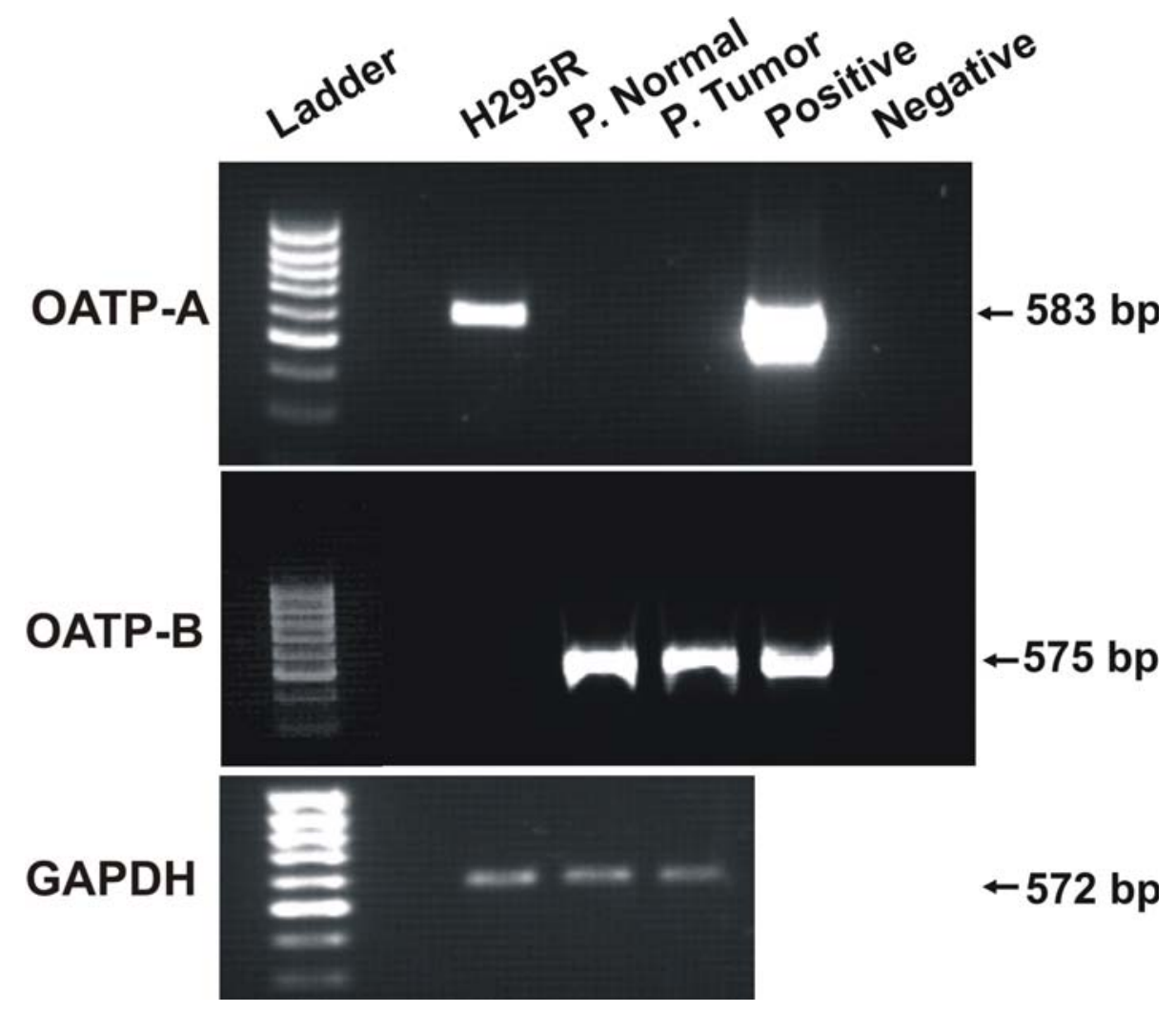

Figure 4.14 RT-PCR profiling of NCl-H295R cells, human normal, and tumor adrenal tissue for organic anion transporter polypeptides. The cDNA from NCl-H295R cells, human normal and tumor adrenal tissue was used as a template, along with specific primers of OATP-A, OATP-B, OATP-C, OATP-E and GAPDH for PCR. GAPDH was used as a reference for the quantification of CDNA used for PCR. The PCR from respective plasmids of OATP-A, and OATP-B were used as standard positive control.

\subsubsection{Expression of key enzymes for steroid biosynthesis}

Members of cytochrome P450 enzymes play a vital role in biosynthesis of steroid hormones from adrenal glands. To evaluate the expression of key cytochrome P450 enzymes of steroid biosynthesis, semi-quantitative PCR experiments were conducted. The total RNA extracted from NCl-H295R cell line, adrenal normal and tumor tissues was subjected to cDNA synthesis. The specified fragments were amplified by using specific primers for steroidogenic-acute-regulatory protein (StaR), side-chain cleavage enzyme desmolase (CYP11A1), 17 $\alpha$-hydroxylase/17,20 lyase

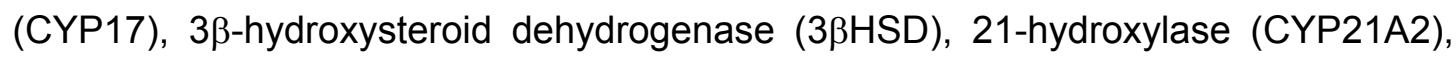


and steroid 11ß-hydroxylase (CYP11B1). In order to document the degree of variation in the expression of these enzymes in $\mathrm{NCl}-\mathrm{H} 295 \mathrm{R}$ cell line, normal and tumor adrenal tissues, we normalized their expression levels relative to that of GAPDH.

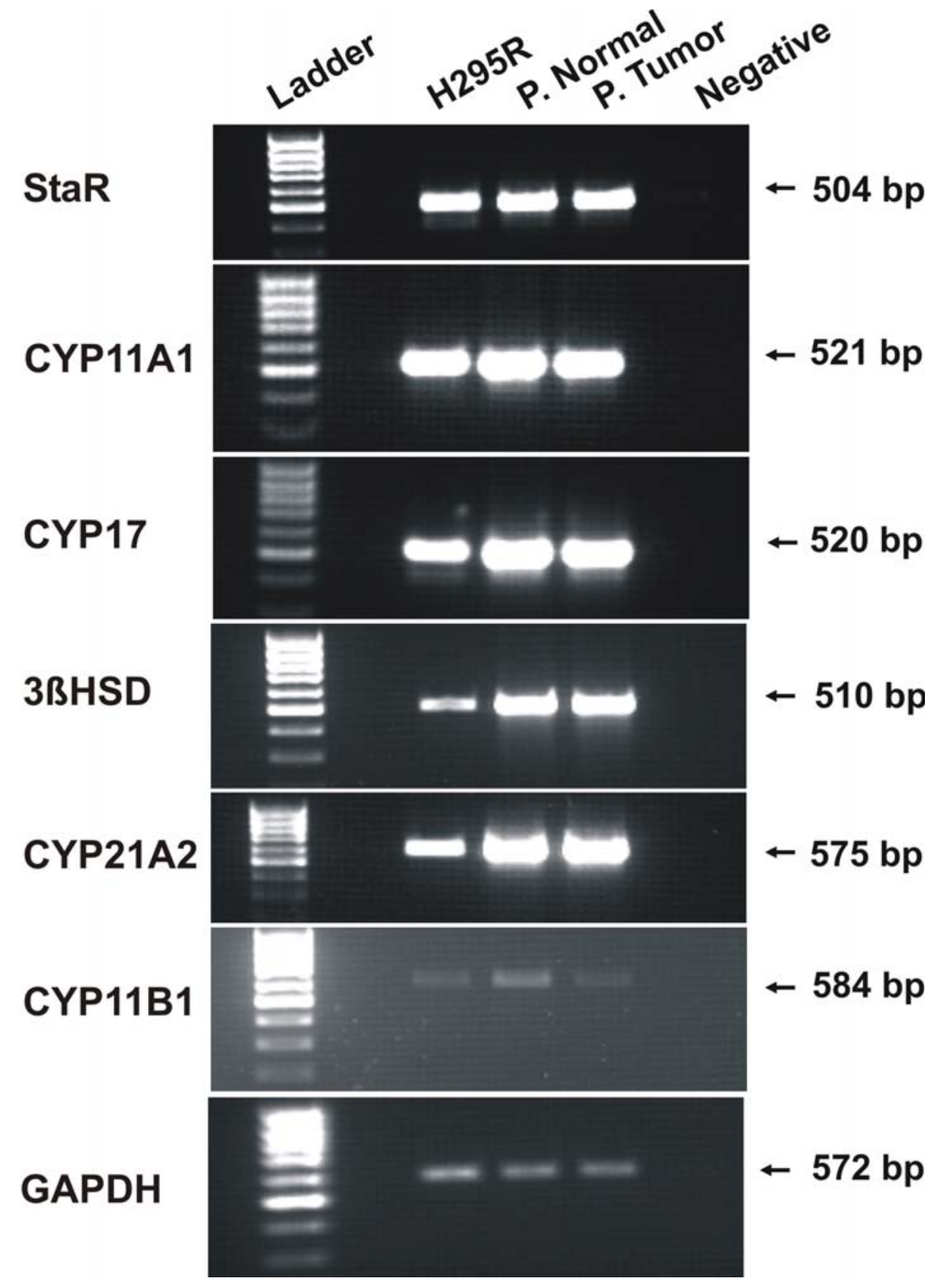

Figure 4.15 RT-PCR profiling of $\mathrm{NCl}-\mathrm{H} 295 \mathrm{R}$ cells, normal, and tumor adrenal tissue for members of cytochrome P450. The cDNA from NCl-H295R cell line, normal and tumor adrenal tissues was used as a template, along with specific primers of StaR, CYP11A1, CYP17, 3BHSD, CYP21A2, CYP11B1 and GAPDH for PCR. GAPDH was used as a reference for the quantification of $\mathrm{CDNA}$ used for PCR. (StaR $=$ steroidogenic-acuteregulatory protein, $\mathrm{CYP} 11 \mathrm{~A} 1=$ side-chain cleavage enzyme desmolase, $\mathrm{CYP} 17=17 \alpha$ hydroxylase $/ 17,20$ lyase, $3 \beta \mathrm{HSD}=3 \beta$-hydroxysteroid dehydrogenase, $\mathrm{CYP} 21 \mathrm{~A} 2=21-$ hydroxylase, and CYP11B1 = steroid 11 $\beta$-hydroxylase). 
Signals for expression of all the above-mentioned enzymes were detected in $\mathrm{NCl}$ H295R cells, adrenal tumor and normal tissues. The results demonstrated that expression of all steroid biosynthesis enzymes were relatively high in normal and tumor tissues in comparison to $\mathrm{NCl}-\mathrm{H} 295 \mathrm{R}$ cell line. However there was no significant difference of expression between tumor and normal adrenal tissue.

\subsection{CORTISOL UPTAKE IN HUMAN OAT EXPRESSING Xenopus laevis OOCYTES}

Although many reports have been published on the inhibitory effect of steroids on organic anion transporters, so far none of these transporters has been checked for a direct transport of steroids like cortisol (Beery et al. 2003; Hagenbuch et al. 2003; Inaba et al. 1974; Whitehouse et al. 1971). Therefore we investigated, if human OAT1, OAT3, and OAT4 are capable of transporting cortisol. For this purpose, we expressed human OAT1, OAT2, OAT3, and OAT4 in oocytes and performed uptake experiments with radiolabeled cortisol.

\subsubsection{Radiolabeled cortisol uptake in human OAT1 and OAT2 expressing Xenopus laevis oocytes}

The human OAT1 expressing oocytes exhibited a 27-fold greater $\left[{ }^{3} \mathrm{H}\right] \mathrm{PAH}$ uptake than water-injected oocytes: $100 \pm 9.2 \%(P<0.0001)$ versus $3.7 \pm 0.1 \%$ as shown in figure 4.16, panel A. In contrast, hOAT1 expressing oocytes did not show any significant transport of $\left[{ }^{3} \mathrm{H}\right]$ cortisol as compared to water-injected control oocytes: $100 \pm 2.7 \%$ versus $100.7 \pm 5.5 \%$ (B). These results demonstrate that hOAT1 protein was functionally expressed in oocytes, but does not transport cortisol.

Human OAT2 expressing oocytes were subjected to $\left[{ }^{14} \mathrm{C}\right]$ salicylic acid uptake (a potent substrate of hOAT2) and $\left[{ }^{3} \mathrm{H}\right]$ cortisol. There was neither significant uptake for $\left[{ }^{14} \mathrm{C}\right]$ salicylic acid nor for $\left[{ }^{3} \mathrm{H}\right]$ cortisol. We conclude from the results that there was no functional protein expression by the available clone of hOAT2. Hence, we were not able to document the ability of hOAT2 to transport cortisol. 

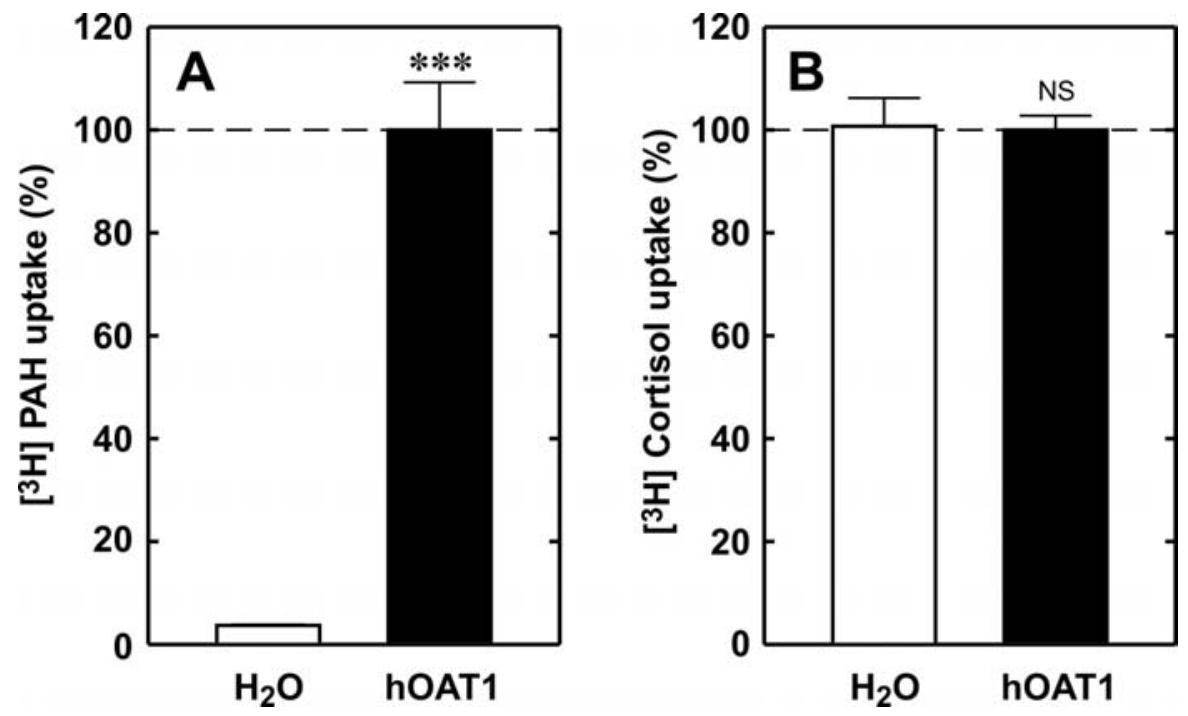

Figure 4.16 hOAT1 mediated uptake in Xenopus laevis oocytes. Three days after injection with either human OAT1 cRNA, or water, the uptake of $(A)\left[{ }^{3} \mathrm{H}\right] \mathrm{PAH}(5 \mu \mathrm{Ci} / \mathrm{ml}, 1$ $\mu \mathrm{M})$, and $(B)\left[{ }^{3} \mathrm{H}\right]$ cortisol $(1.4 \mu \mathrm{Ci} / \mathrm{ml}, 14 \mathrm{nM})$ was performed for $1 \mathrm{~h}$ in ORI. Data represent means \pm SEM of three independent experiments with 7-11 oocytes/group in each experiment. In each experiment, uptake of $\left[^{3} \mathrm{H}\right] \mathrm{PAH}$ or $\left[{ }^{3} \mathrm{H}\right]$ cortisol by hOAT1 cRNA-injected oocytes was set to $(100 \%)$. The significance was calculated by student's t-test against water-injected oocytes $\left({ }^{* *}, \mathrm{P}<0.0001\right.$; NS $=$ not significant).

\subsection{2}

\section{Radiolabeled cortisol uptake experiments in human OAT4 expressing Xenopus laevis oocytes}

RT-PCR signals for human OAT4 were present both in NCl-H295R cells as well as in
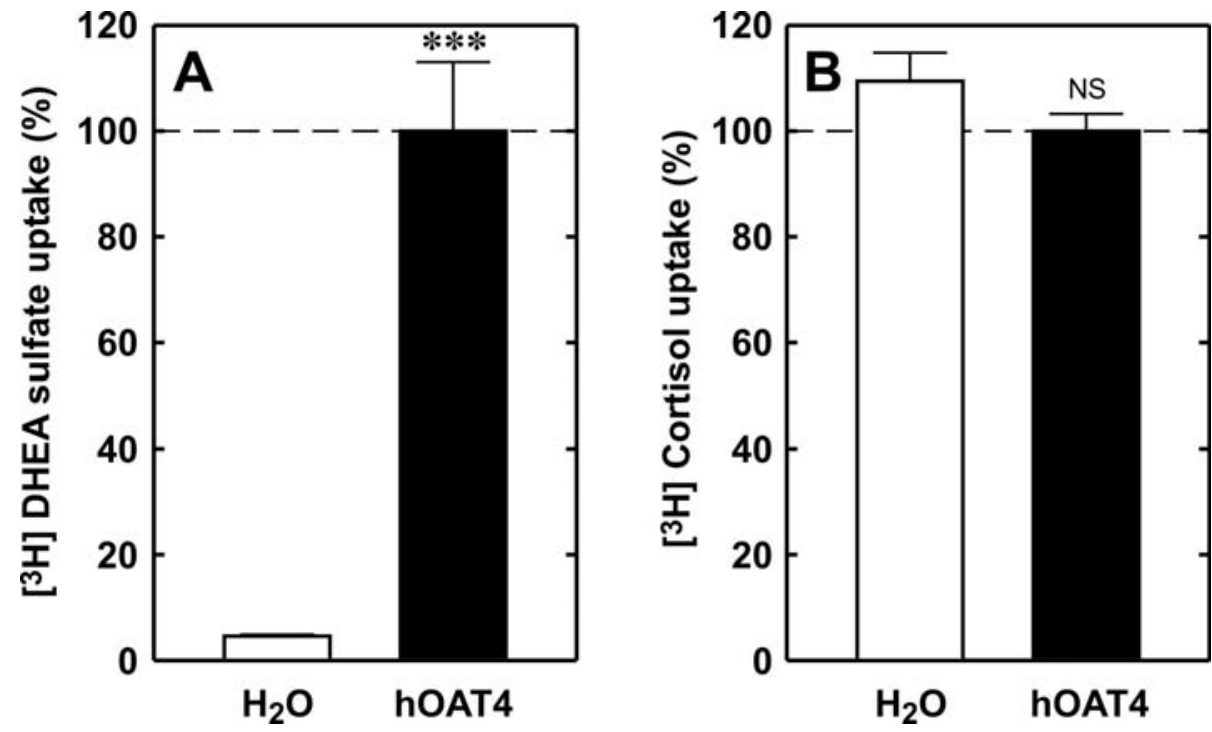

Figure 4.17 OAT4 mediated uptake experiments in Xenopus laevis oocytes. Three days after injection with either human OAT4 CRNA, or water, the uptake of $\left.(A){ }^{3} \mathrm{H}\right] \mathrm{DHEAS}(0.74$ $\mu \mathrm{Ci} / \mathrm{ml}, 10 \mathrm{nM})$, and $(B)\left[{ }^{3} \mathrm{H}\right]$ cortisol $(1.4 \mu \mathrm{Ci} / \mathrm{ml}, 14 \mathrm{nM})$ was performed for $1 \mathrm{~h}$ in ORI. Data represent means \pm SEM of four independent experiments with 6-10 oocytes/group in each experiment. In each experiment radiolabeled uptake in hOAT4 cRNA-injected oocytes was set to $100 \%$. The significance was calculated by student's t-test against water-injected oocytes $\left({ }^{* * *}, \mathrm{P}<0.0001 ; \mathrm{NS}=\right.$ not significant). 
human adrenal tissues. Human OAT4 expressing oocytes were checked for the typical substrate $\left[{ }^{3} \mathrm{H}\right] \mathrm{DHEAS}$. hOAT4 showed a 22 -fold greater $\left[{ }^{3} \mathrm{H}\right] \mathrm{DHEAS}$ transport than water-injected oocytes: $100 \pm 13.1 \%(P<0.0001)$ versus $4.5 \pm 0.3 \%$ (Figure 4.17, panel A). When human OAT4 oocytes were incubated with $\left[{ }^{3} \mathrm{H}\right]$ cortisol, no significant uptake was observed over water-injected oocytes: $100 \pm 3.2 \%$ versus $109.4 \pm 5.4 \%(B)$.

\subsubsection{Radiolabeled cortisol uptake in human OAT3 expressing Xenopus laevis oocytes}

Human OAT3 expressing Xenopus laevis oocytes showed a significant $\left[{ }^{3} \mathrm{H}\right]$ estrone sulfate uptake compared to water-injected oocytes: $100 \pm 4.6 \%(P<0.0001)$ versus $1.6 \pm 0.1 \%$ (Figure 4.18, panel A). In comparison to hOAT1 and hOAT4, hOAT3 expressing oocytes exhibited a significant $\left[{ }^{3} \mathrm{H}\right]$ cortisol transport, almost fourfold over water-injected oocytes: $100 \pm 2.8 \%(P<0.0001$ ) versus $26.9 \pm 1.2 \%$ (Figure 4.18, panel B). These results demonstrate for the first time a hOAT3-mediated cortisol transport.
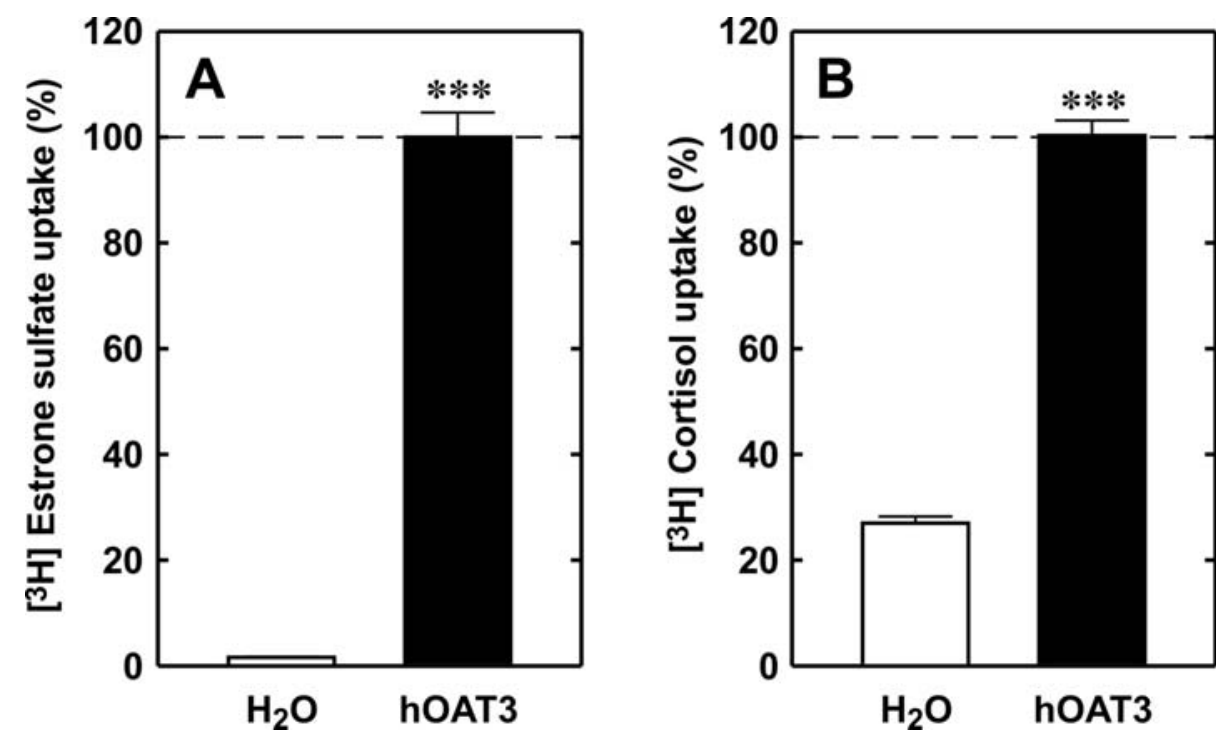

Figure 4.18 OAT3 mediated uptake experiments in Xenopus laevis oocytes. Three days after injection with either human OAT3 cRNA, or water, the uptake of $(A)\left[{ }^{3} \mathrm{H}\right]$ estrone sulfate $(0.44 \mu \mathrm{Ci} / \mathrm{ml}, 10 \mathrm{nM})$, and $\left[{ }^{3} \mathrm{H}\right]$ cortisol $(1.4 \mu \mathrm{Ci} / \mathrm{ml}, 14 \mathrm{nM})$ was performed for $1 \mathrm{~h}$ in ORI. Data represent means \pm SEM of more than six independent experiments with 9-12 oocytes/group in each experiment. In each experiment uptake of $\left[{ }^{3} \mathrm{H}\right]$ estrone sulfate or $\left[{ }^{3} \mathrm{H}\right]$ cortisol by hOAT3 cRNA-injected oocytes was set to $(100 \%)$. The significance was calculated by student's t-test against water-injected oocytes $\left({ }^{* * *}, \mathrm{P}<0.0001\right)$. 
4.5.4 Concentration dependent inhibition of radiolabeled cortisol uptake by unlabeled cortisol in hOAT3 expressing Xenopus laevis oocytes

We checked whether this $\left[{ }^{3} \mathrm{H}\right]$ cortisol transport by hOAT3 can be inhibited by unlabeled cortisol. For this purpose, $\left[{ }^{3} \mathrm{H}\right]$ cortisol uptake into hOAT3 was carried out in the presence of different concentrations of unlabeled cortisol and control without exposure to unlabeled cortisol. The results are shown in figure 4.19. The apparent $K_{t}$ value of hOAT3 for cortisol was $2.4 \pm 0.6 \mu \mathrm{M}$ in oocytes.

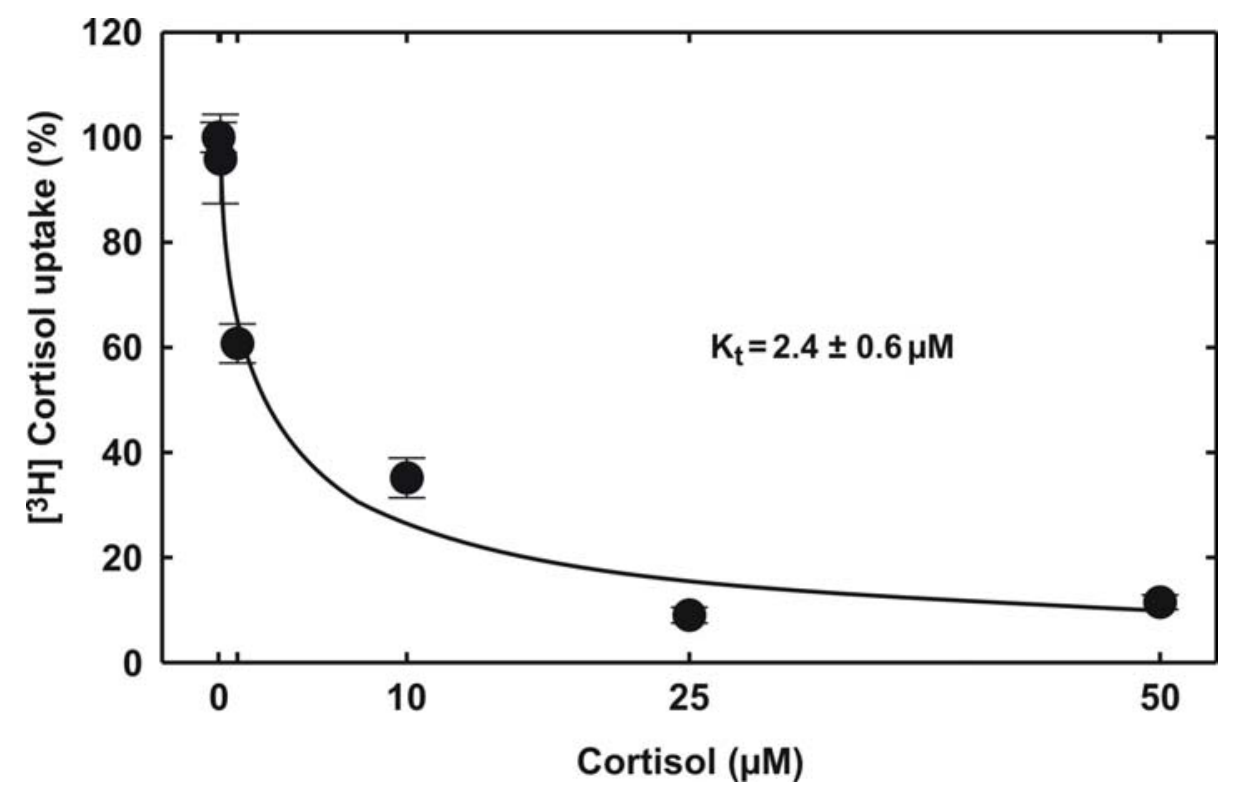

Figure 4.19 Inhibition of $\left[^{3} \mathrm{H}\right]$ cortisol uptake by unlabeled cortisol in hOAT3 expressing Xenopus laevis oocytes. Three days after injection with either human OAT3 cRNA or water, the $\left[{ }^{3} \mathrm{H}\right]$ cortisol $(1.4 \mu \mathrm{Ci} / \mathrm{ml}, 14 \mathrm{nM})$ uptake was performed for $1 \mathrm{~h}$ in the presence of $0.1 \mu \mathrm{M}$, $1.0 \mu \mathrm{M}, 10 \mu \mathrm{M}, 25 \mu \mathrm{M}$, or $50 \mu \mathrm{M}$ unlabeled cortisol. Data represent means \pm SEM of four independent experiments with 8-10 oocytes/group in each experiment. Apparent $\mathrm{K}_{t}$ value was calculated according to the Hill equation using SigmaPlot 2001.

\subsubsection{Inhibition of radiolabeled estrone sulfate uptake in human OAT3 expressing Xenopus laevis oocytes by unlabeled cortisol}

As estrone sulfate is a good substrate of hOAT3, we checked if $\left[{ }^{3} \mathrm{H}\right]$ estrone sulfate uptake could be inhibited by unlabeled cortisol. $\left[{ }^{3} \mathrm{H}\right]$ estrone sulfate uptake was conducted in hOAT3 cRNA injected oocytes, in the presence of different concentrations of unlabeled cortisol or absence of unlabeled cortisol (control), as shown in the figure 4.20. The calculated $I_{50}$ value for cortisol was $15.6 \pm 2.3 \mu \mathrm{M}$. 


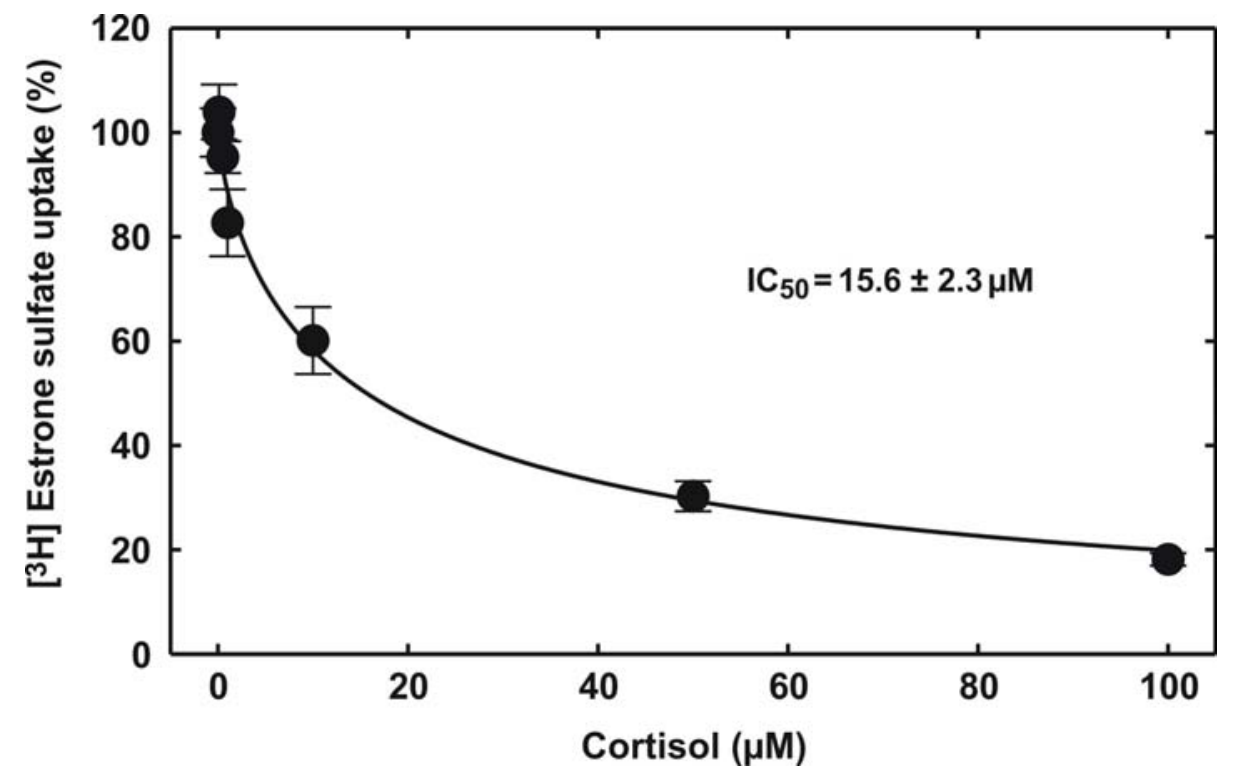

Figure 4.20 Inhibition of $\left[{ }^{3} \mathrm{H}\right]$ estrone sulfate uptake by unlabeled cortisol in hOAT3 expressing Xenopus laevis oocytes. Three days after injection with either human OAT3 cRNA or water, the $\left[{ }^{3} \mathrm{H}\right]$ estrone sulfate $(0.44 \mu \mathrm{Ci} / \mathrm{ml}, 10 \mathrm{nM})$ uptake was performed for $1 \mathrm{~h}$ in the presence of $0.1 \mu \mathrm{M}, 0.5 \mu \mathrm{M}, 1.0 \mu \mathrm{M}, 10 \mu \mathrm{M}$, or $50 \mu \mathrm{M}$ unlabeled cortisol. Data represent means \pm SEM of four independent experiments with 8-10 oocytes/group in each experiment. $\mathrm{IC}_{50}$ value was calculated according to the Hill equation using SigmaPlot 2001.

DHEAS is an important steroid hormone, which is also transported by OAT3, OAT4 and many other OATPs. Human OAT3-expressing Xenopus laevis oocytes showed a sixtyfold higher $\left[{ }^{3} \mathrm{H}\right] \mathrm{DHEAS}$ uptake as compared to water-injected oocytes: $100 \pm$ $5.0 \%(\mathrm{P}<0.0001)$ versus $1.6 \pm 0.9 \%$. The $\left[{ }^{3} \mathrm{H}\right] \mathrm{DHEAS}$ uptake was inhibited by $1 \mathrm{mM}$ unlabeled DHEAS to $1.8 \pm 0.2 \%(\mathrm{P}<0.0001)$. The cis-inhibition of $\left[{ }^{3} \mathrm{H}\right] \mathrm{DHEAS}$ uptake with $50 \mu \mathrm{M}$ and $100 \mu \mathrm{M}$ unlabeled cortisol showed significant reduction to $18.2 \pm 1.8 \%(P<0.0001)$, and $11.6 \pm 0.8 \%(P<0.0001)$, respectively. These results are similar to the results we obtained from $\left[{ }^{3} \mathrm{H}\right]$ estrone sulfate uptake and its inhibition with cortisol, confirming an affinity of hOAT3 for cortisol.

\subsection{CORTISOL UPTAKE IN HUMAN OATP EXPRESSING Xenopus laevis OOCYTES}

By RT-PCR, we detected signals for OATP-A in NCl-H295R cells, while OATP-B mRNA expression was observed both in normal and tumor adrenal tissue. To check the ability of OATP-A and OATP-B for cortisol transport, we expressed these transporters polypeptides separately in Xenopus laevis oocytes and checked for the radiolabeled uptake of their typical substrates and labeled cortisol. The results were compared with water-injected oocytes. 
Since estrone sulfate is a known substrate of OATP-A, we validated the expression quality by $\left[{ }^{3} \mathrm{H}\right]$ estrone sulfate uptake. OATP-A showed a significant higher $\left[{ }^{3} \mathrm{H}\right]$ estrone sulfate uptake $100 \pm 6.7 \%$ than water injected oocytes $4.0 \pm 0.4 \%(P<$ 0.0001 ), confirming that OATP-A, protein is functionally expressed in the injected oocytes. $\left[{ }^{3} \mathrm{H}\right]$ cortisol uptake by water injected oocytes was $74.1 \pm 3 . \%(P<0.0001)$ in comparison to OATP-A injected oocytes $100 \pm 1.1 \%$. Thereby, cortisol uptake in OATP-A injected oocytes was significantly higher with reference to water injected cells.
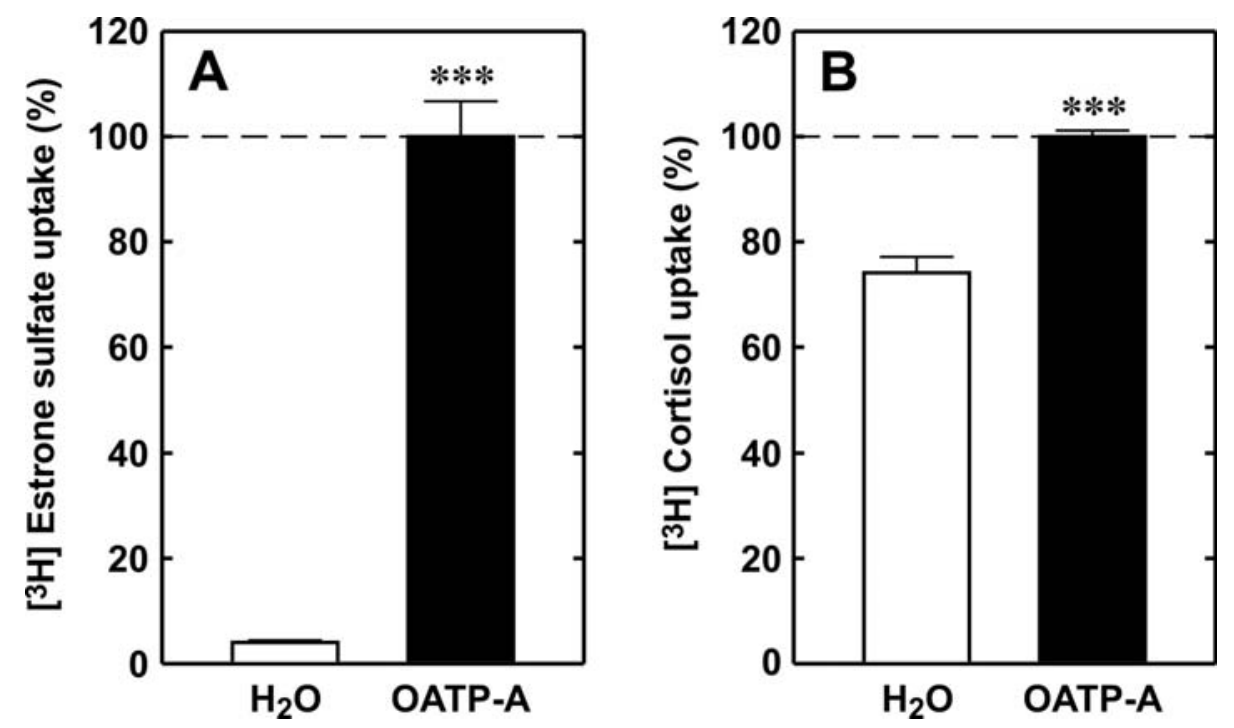

Figure 4.21 OATP-A mediated uptake experiments in Xenopus laevis oocytes. Three days after injection with either human OATP-A cRNA, or water, the uptake of $(A)\left[{ }^{3} \mathrm{H}\right]$ estrone sulfate $(0.44 \mu \mathrm{Ci} / \mathrm{ml}, 10 \mathrm{nM})$, and $\left.{ }^{3} \mathrm{H}\right]$ cortisol $(1.4 \mu \mathrm{Ci} / \mathrm{ml}, 14 \mathrm{nM})$ was performed for $1 \mathrm{~h}$ in ORI. Data represent means \pm SEM of three independent experiments with 10-17 oocytes/group in each experiment. In each experiment uptake of $\left[^{3} \mathrm{H}\right]$ estrone sulfate or $\left[{ }^{3} \mathrm{H}\right]$ cortisol by OATP-A cRNA-injected oocytes was set to $(100 \%)$. The significance was calculated by student's t-test against water-injected oocytes $\left({ }^{* * *}, \mathrm{P}<0.0001\right)$.

Organic anion transporter polypeptide-B (OATP-B) expressing oocytes were also checked for the ability to transport $\left[{ }^{3} \mathrm{H}\right]$ estrone sulfate. There was no significant difference observed between water injected and OATP-B injected oocytes. In case of $\left[{ }^{3} \mathrm{H}\right]$ cortisol there was also no difference between water injected and OATP-B injected oocytes. As this clone did not transport $\left[{ }^{3} \mathrm{H}\right]$ estrone sulfate, we do not have any functional control. 


\subsection{RADIOLABELED SUBSTANCES UPTAKE IN hOATS STABLY TRANSFECTED HEK-293 CELLS}

Human embryonic kidney (HEK-293) cells were stably transfected with genes of interest (hOAT1, hOAT3, or hOAT4) containing vector or with control vector without construct of gene of interest. Cells were grown as monolayer and were sub-cultured in 24 well plates at least 48 hours before performing the experiments. The uptake of the main substrates of the respective clone was used to check the function of the expressed gene. The HEK-293 cells transfected alone with vector were used as control.

\subsubsection{Inhibition of $\left[{ }^{3} \mathrm{H}\right] \mathrm{PAH}$ uptake by unlabeled cortisol in hOAT1 stably transfected HEK-293 cells}

To control the effect of cortisol on PAH uptake by hOAT1 transfected HEK-293 cells, we performed $\mathrm{PAH}$ uptake experiments and tried to inhibit the uptake by different concentrations of unlabeled cortisol. As a reference for the inhibition, $100 \mu \mathrm{M}$ probenecid was used to inhibit the PAH uptake in parallel experiments.

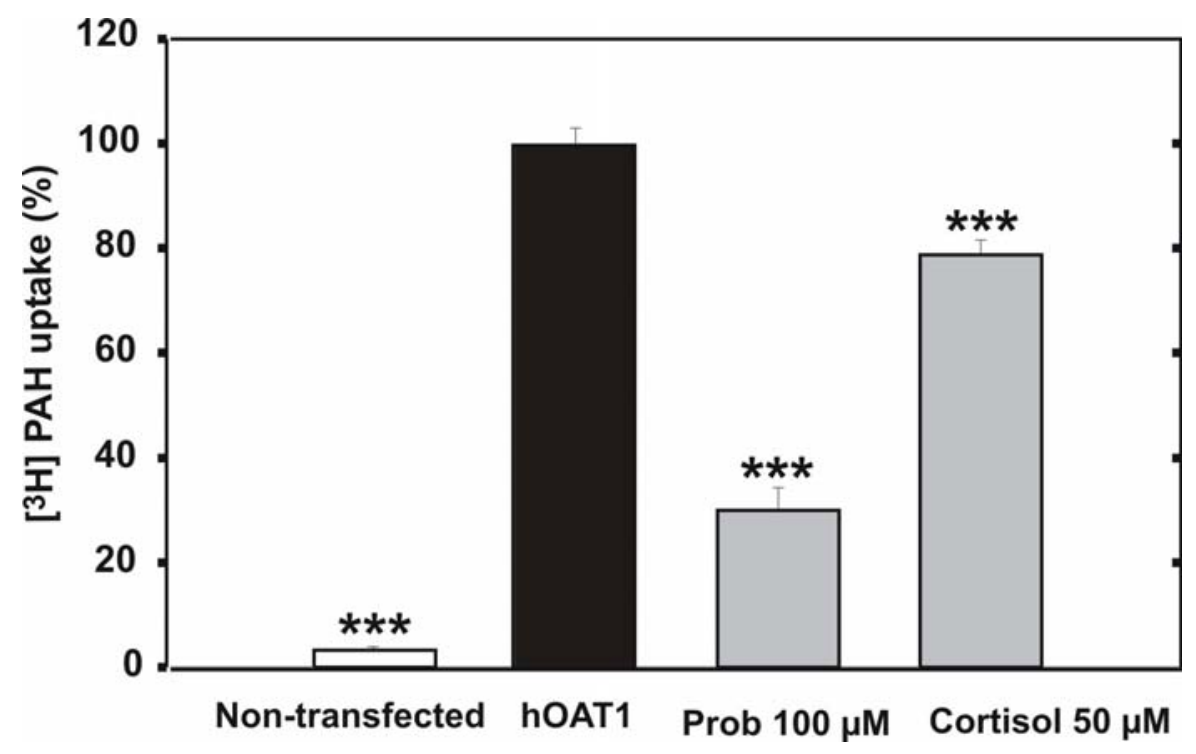

Figure 4.22 Inhibition of $\left[{ }^{3} \mathrm{H}\right] \mathrm{PAH}$ uptake into hOAT1 stably transfected HEK-293 cells by probenecid and unlabeled cortisol. Cells cultured in 24-well plates were incubated for one min with Ringer solution containing $\left[{ }^{3} \mathrm{H}\right] \mathrm{PAH}(5 \mu \mathrm{Ci} / \mathrm{ml}, 1 \mu \mathrm{M})$ at $\mathrm{RT}$, in the presence and absence of cortisol or probenecid. The total radioactivity taken up by the cells was measured. Each column is calculated as percentage of $\left[{ }^{3} \mathrm{H}\right] \mathrm{PAH}$ uptake of hOAT1 stably transfected HEK-293 cells without cortisol or probenecid as (100\%) within the same experiment. Data represent means \pm SEM of five independent experiments with 3 wells per condition in each experiment. The significance was calculated by student's t-test against the hOAT1 stably transfected HEK-293 cells $\left({ }^{* * *}, \mathrm{P}<0.0001\right)$. 
Non-transfected HEK-293 cells showed $3.2 \pm 0.6 \%(P<0.0001)\left[{ }^{3} \mathrm{H}\right] \mathrm{PAH}$ uptake as compared to hOAT1 transfected cells; $100 \pm 2.9 \%$. When we added $100 \mu \mathrm{M}$ probenecid in the uptake medium, $\left[{ }^{3} \mathrm{H}\right] \mathrm{PAH}$ uptake was only $30.0 \pm 4.3 \%$ ( $\mathrm{P}<$ 0.0001). In the presence of $50 \mu \mathrm{M}$ unlabeled cortisol, hOAT1 transfected cells showed $78.7 \pm 2.8 \%(\mathrm{P}<0.0001)$ of $\left[{ }^{3} \mathrm{H}\right] \mathrm{PAH}$ uptake in comparison to control $(100 \pm$ $2.9 \%)$.

Cortisol at a concentration of $0.1 \mu \mathrm{M}$ did not cause any significant reduction in $\left[{ }^{3} \mathrm{H}\right] \mathrm{PAH}$ uptake. However, higher cortisol concentrations; $1 \mu \mathrm{M}, 10 \mu \mathrm{M}$, and $25 \mu \mathrm{M}$ reduced $\left[{ }^{3} \mathrm{H}\right] \mathrm{PAH}$ uptake to $85.6 \pm 2.7 \%(\mathrm{P}<0.005), 85.1 \pm 3.8 \%(\mathrm{P}<0.005)$, and $84.3 \pm 2.2 \%(P<0.001)$, respectively, in comparison to the control $100 \pm 2.9 \%$.

\subsubsection{Inhibition of $\left[{ }^{3} \mathrm{H}\right]$ estrone sulfate uptake by unlabeled cortisol in HEK-293 cells stably transfected with hOAT3}

Human OAT3 expressing oocytes showed a fourfold higher uptake as compared to water-injected oocytes. The $\left[{ }^{3} \mathrm{H}\right]$ estrone sulfate uptake into hOAT3 expressing oocytes was also inhibited by cortisol with an $\mathrm{IC}_{50}$ value of $15.6 \mu \mathrm{M}$. We also checked

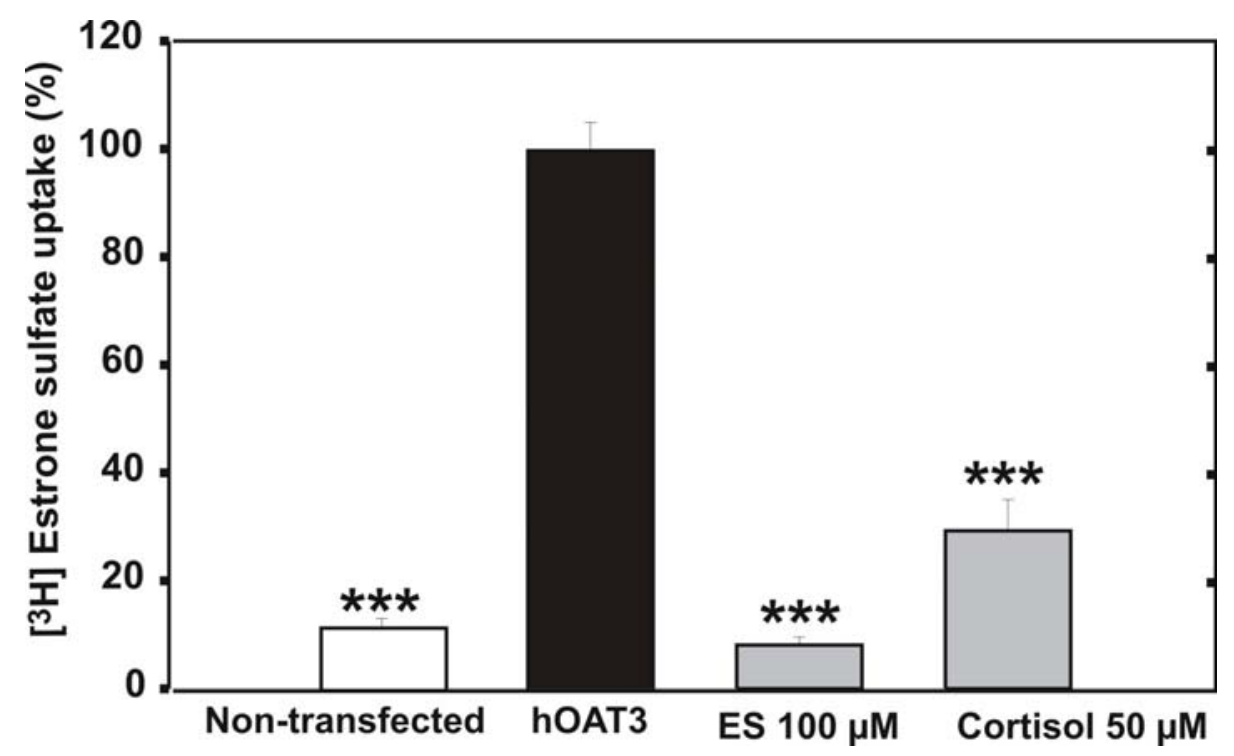

Figure 4.23 Inhibition of $\left[{ }^{3} \mathrm{H}\right]$ estrone sulfate uptake into hOAT3 transfected HEK-293 cells by unlabeled ES and cortisol Cells cultured in 24-well plates were incubated for one min with Ringer solution containing $\left[{ }^{3} \mathrm{H}\right]$ estrone sulfate $(0.44 \mu \mathrm{Ci} / \mathrm{ml}, 10 \mathrm{nM})$ at $\mathrm{RT}$, in the presence and absence of cortisol or unlabeled estrone sulfate. The total radioactivity taken up by the cells was measured. Each column is calculated as percentage of $\left.{ }^{3} \mathrm{H}\right]$ estrone sulfate uptake of hOAT3 stably transfected HEK-293 cells without cortisol or unlabeled estrone sulfate as $(100 \%)$ within the same experiment. Data represent means \pm SEM of more then five independent experiments with 3 wells per condition in each experiment. The significance was calculated by student's t-test against the hOAT3 stably transfected HEK-293 cells $\left(^{* * *}, \mathrm{P}\right.$ $<0.0001)$. 
the cis-inhibitory effect of cortisol on $\left[{ }^{3} \mathrm{H}\right]$ estrone sulfate uptake in hOAT3 stably transfected HEK-293 cells. These cells showed eightfold more $\left[{ }^{3} \mathrm{H}\right]$ estrone sulfate uptake than non-transfected cells; $100 \pm 4.9 \%$ versus $11.5 \pm 1.4 \%(P<0.0001)$. $\left[{ }^{3} \mathrm{H}\right]$ estrone sulfate uptake in hOAT3 transfected HEK-293 cells could be reduced to $8.1 \pm 1.4 \%(P<0.0001)$ by $100 \mu \mathrm{M}$ unlabeled estrone sulfate.

The presence of $50 \mu \mathrm{M}$ cortisol in the uptake medium reduced $\left[{ }^{3} \mathrm{H}\right]$ estrone sulfate uptake to $29.2 \pm 5.8 \%(P<0.0001)$ of control $(100 \pm 4.9 \%)$. The hOAT3 mediated radiolabeled estrone sulfate uptake was inhibited by cortisol. The calculated $\mathrm{IC}_{50}$ value for cortisol is $21.0 \mu \mathrm{M}$.

\subsection{3 [ $\left.{ }^{3} \mathrm{H}\right] \mathrm{DHEAS}$ uptake into HEK-293 cells transfected with}

\section{hOAT4 and inhibition by unlabeled cortisol}

HEK-293 cell transfected with hOAT4 were checked for transport of $\left[{ }^{3} \mathrm{H}\right] \mathrm{DHEAS}$. Non-transfected HEK-293 cells showed $5.8 \pm 0.5 \%(P<0.0001)\left[{ }^{3} \mathrm{H}\right]$ DHEAS uptake as compared to hOAT4 transfected control cells $(100 \pm 2.2 \%)$. The presence of 100 $\mu \mathrm{M}$ unlabeled estrone sulfate decreased the $\left[{ }^{3} \mathrm{H}\right] \mathrm{DHEAS}$ uptake to $45.8 \pm 7.8 \%$ ( $\mathrm{P}<$ $0.0001)$.

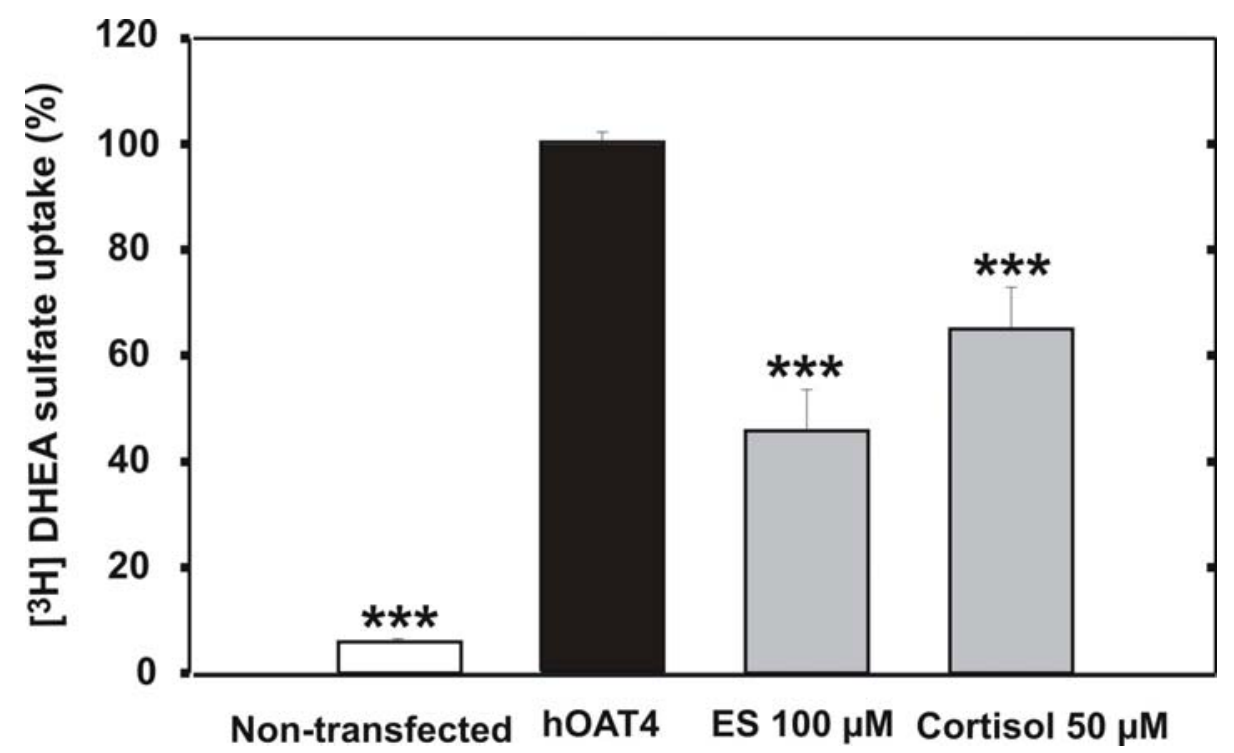

Figure 4.24 [ ${ }^{3} \mathrm{H}$ ]DHEAS uptake into hOAT4 transfected HEK-293 cells. Cells cultured in 24 -well plates were incubated for one min with Ringer solution containing $\left[{ }^{3} \mathrm{H}\right] \mathrm{DHEAS}(0.74$ $\mu \mathrm{Ci} / \mathrm{ml}, 10 \mathrm{nM}$ ) at RT, in the presence and absence of cortisol or estrone sulfate. The total radioactivity taken up by the cells was measured. Each column is calculated as percentage of $\left[{ }^{3} \mathrm{H}\right] \mathrm{DHEAS}$ uptake of hOAT4 transfected HEK-293 cells without cortisol or estrone sulfate as $(100 \%)$ within the same experiment. Data represent means \pm SEM of five independent experiments with 3 wells per condition in each experiment. The significance was calculated by student's t-test against the hOAT4 stably transfected HEK-293 cells $\left({ }^{* * *}, \mathrm{P}<0.0001\right)$. 
When we incubated the cells with medium containing $50 \mu \mathrm{M}$ unlabeled cortisol the remaining $\left[{ }^{3} \mathrm{H}\right] \mathrm{DHEAS}$ uptake was $64.9 \pm 7.9 \%(P<0.0001)$.

Cortisol at $0.1 \mu \mathrm{M}$ concentration did not produce any significant reduction in $\left[{ }^{3} \mathrm{H}\right] \mathrm{DHEAS}$ uptake. In the presence of $1 \mu \mathrm{M}, 10 \mu \mathrm{M}, 25 \mu \mathrm{M}$, and $50 \mu \mathrm{M}$ unlabeled cortisol in the uptake medium, OAT3 mediated uptake was reduced from $100 \pm 2.5$ to $84.8 \pm 3.4 \%(P<0.001), 80.4 \pm 3.1 \%(P<0.0001), 80.9 \pm 2.9 \%(P<0.0001)$, and $62.2 \pm 9.4 \%(P<0.0001)$, respectively.

\subsection{ESTRONE SULFATE UPTAKE BY NCI-H295R CELLS}

Expression studies indicated the presence of human OAT3 and OAT4 in NCl-H294R cells. Furthermore the fourfold greater cortisol uptake by human OAT3 expressing oocytes emphasized the need to check whether $\mathrm{NCl}-\mathrm{H} 295 \mathrm{R}$ cells transport substrates of OAT3. Cells were seeded in the 24 -well plates at least 48 hours before the experiments. At the start of the experiment cells were washed three times with pre-warmed Ringer solution and incubated with $10 \mathrm{nM}\left[{ }^{3} \mathrm{H}\right]$ estrone sulfate for indicated time. The cells were washed three times with ice-cold Ringer solution and then measured. The results were standardized by determining the protein concentration of each well by the Bradford assay.

\subsubsection{Time-course of $\left[{ }^{3} \mathrm{H}\right]$ estrone sulfate uptake into $\mathrm{NCl}-\mathrm{H} 295 \mathrm{R}$ cells.}

Initially we measured the time dependency of the $\left[{ }^{3} \mathrm{H}\right]$ estrone sulfate uptake into $\mathrm{NCl}$ H295R cells. [ ${ }^{3} \mathrm{H}$ ]Estrone sulfate uptake of $10 \mathrm{~min}$ was calculated as $100 \pm 3.6 \%$, the uptake at $1,2,5,15$, and $20 \min$ was $44.8 \pm 1.9 \%, 50.5 \pm 3.2 \%, 73.2 \pm 3.4 \%, 112.1 \pm$ $4.4 \%$, and $149.1 \pm 3.5 \%$, respectively, of the $10 \mathrm{~min}$. For all other experiments $10 \mathrm{~min}$ incubation time was used if not mentioned otherwise. 


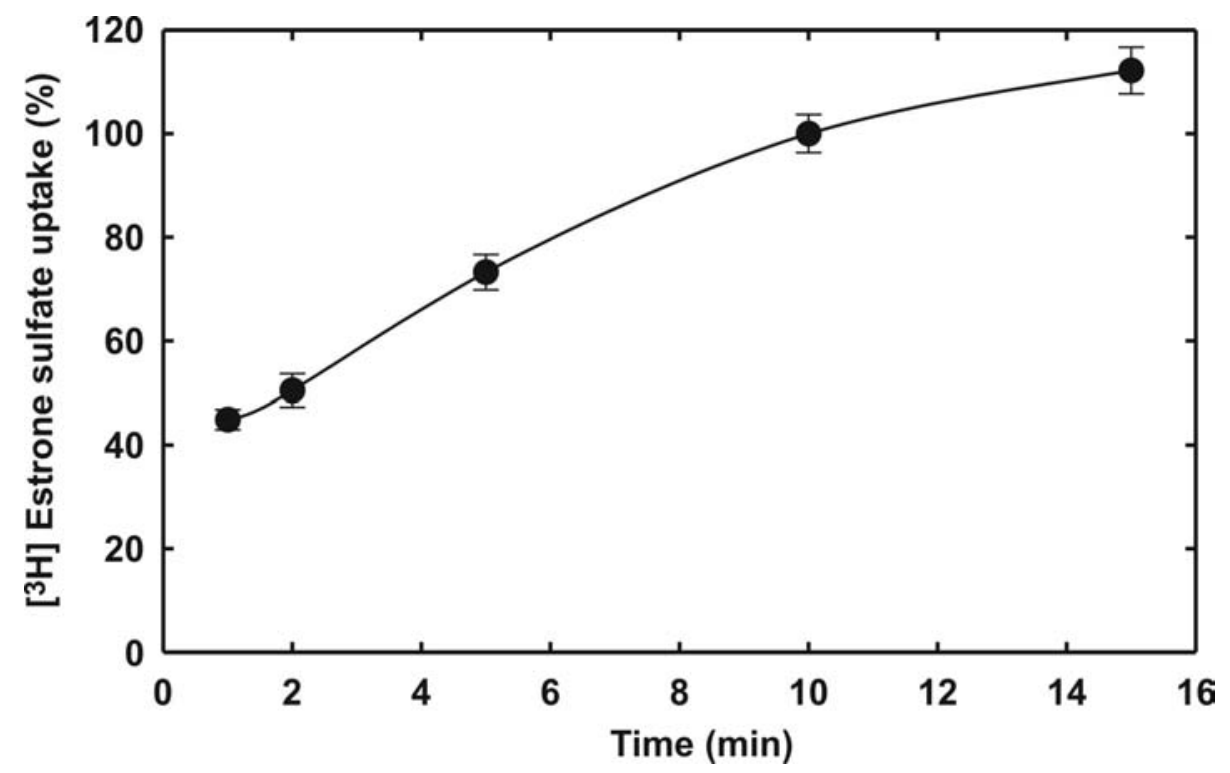

Figure 4.25 Time-course of $\left[{ }^{3} \mathrm{H}\right]$ estrone sulfate uptake into $\mathrm{NCl}-\mathrm{H} 295 \mathrm{R}$ cells. Cells grown in 24-well plates were incubated for the indicated time periods with $\left[{ }^{3} \mathrm{H}\right]$ estrone sulfate $(0.44$ $\mu \mathrm{Ci} / \mathrm{ml}, 10 \mathrm{nM}$ ) at RT. The total radioactivity taken up by the cells was measured. Each point represents an independent group and means \pm SEM of more than four independent experiments with 3 wells per condition in each experiment.

\subsubsection{Stimulation of $\left[{ }^{3} \mathrm{H}\right]$ estrone sulfate uptake into $\mathrm{NCl}-\mathrm{H} 295 \mathrm{R}$ cells by forskolin}

Forskolin treatment showed a 30 fold increase in cortisol release from $\mathrm{NCl}-\mathrm{H} 295 \mathrm{R}$ cells (Figure 4.2), and also increased radiolabeled $\mathrm{PAH}$ uptake into $\mathrm{NCl}-\mathrm{H} 295 \mathrm{R}$ cells (Figure 4.8). To examine whether forskolin treatment could influence the $\left[{ }^{3} \mathrm{H}\right]$ estrone sulfate uptake into the cells, we stimulated the cells $24 \mathrm{~h}$ with $10 \mu \mathrm{M}$ forskolin before uptake. $\left[{ }^{3} \mathrm{H}\right]$ estrone sulfate uptake by $\mathrm{NCl}-\mathrm{H} 295 \mathrm{R}$ cells increased significantly $(22 \%)$ over non-stimulated cells. The non-stimulated $\mathrm{NCl}-\mathrm{H} 295 \mathrm{R}$ cells showed an $\left[{ }^{3} \mathrm{H}\right]$ estrone sulfate uptake of $78.1 \pm 3.4 \%(\mathrm{P}<0.0001)$ compared to control cells $24 \mathrm{~h}$ pre-stimulated with forskolin (100 $\pm 4.5 \%)$. 


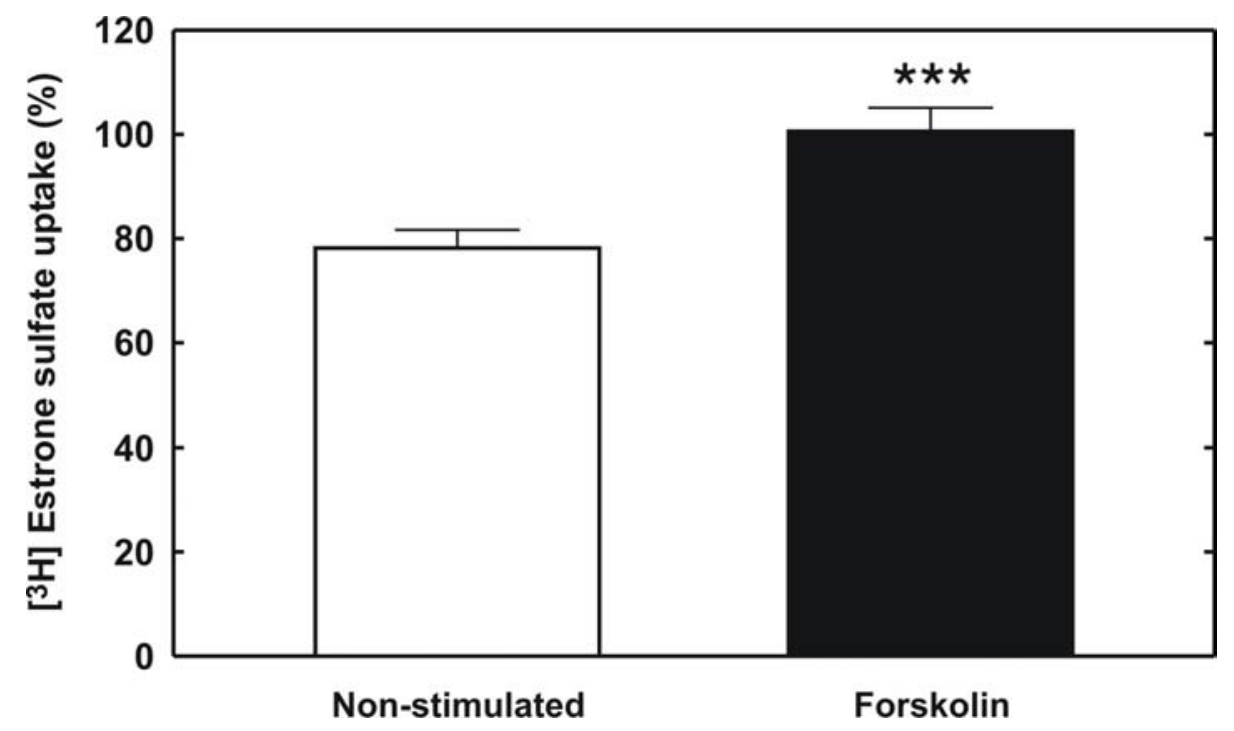

Figure 4.26 Effect of $24 \mathrm{~h}$ forskolin on $\left[^{3} \mathrm{H}\right]$ estrone sulfate uptake into $\mathrm{NCI}-\mathrm{H} 295 \mathrm{R}$ cells. Cells grown in 24-well plates were either incubated for $24 \mathrm{~h}$ with medium containing $10 \mu \mathrm{M}$ forskolin (column 2) or in medium without forskolin. At the end of incubation cells were washed, and incubated for $10 \mathrm{~min}$ with $\left[{ }^{3} \mathrm{H}\right]$ estrone sulfate $(0.44 \mu \mathrm{Ci} / \mathrm{ml}, 10 \mathrm{nM})$. Each column is calculated as percentage of $\left[{ }^{3} \mathrm{H}\right]$ estrone sulfate uptake of forskolin pre-stimulated cells $(100 \%)$ within the same experiment. Data represent means \pm SEM of six independent experiments with 3 wells per condition in each experiment. The significance was calculated by student's t-test against the forskolin stimulated group $\left({ }^{* * *}, \mathrm{P}<0.0001\right)$.

\subsubsection{Inhibition of $\left[{ }^{3} \mathrm{H}\right]$ estrone sulfate uptake into $\mathrm{NCl}-\mathrm{H} 295 \mathrm{R}$ cells by unlabeled estrone sulfate and DHEAS}

Initially we checked whether $\left[{ }^{3} \mathrm{H}\right]$ estrone sulfate uptake into $\mathrm{NCl}-\mathrm{H} 295 \mathrm{R}$ cells was concentration dependent. For this purpose, different concentrations of unlabeled estrone sulfate were added along with $\left[{ }^{3} \mathrm{H}\right]$ estrone sulfate into the incubation medium. The results showed a concentration dependent decrease in uptake of $\left[{ }^{3} \mathrm{H}\right]$ estrone sulfate into cells (Figure 4.27). The calculated $\mathrm{K}_{\mathrm{i}}$ value for estrone sulfate uptake in to $\mathrm{NCl}-\mathrm{H} 295 \mathrm{R}$ cells was $9.82 \mu \mathrm{M}$.

DHEAS is another good substrate of hOAT3. To determine whether DHEAS inhibits $\left[{ }^{3} \mathrm{H}\right]$ estrone sulfate uptake into forskolin treated $\mathrm{NCl}-\mathrm{H} 295 \mathrm{R}$ cells, different concentrations of unlabeled DHEAS were added along with $\left[{ }^{3} \mathrm{H}\right]$ estrone sulfate to the incubation media. The $\left[{ }^{3} \mathrm{H}\right]$ estrone sulfate uptake demonstrated a concentration dependent inhibition by DHEAS. The calculated $\mathrm{IC}_{50}$ for DHEAS inhibition to $\left[{ }^{3} \mathrm{H}\right]$ estrone sulfate uptake was $10.6 \mu \mathrm{M}$. 


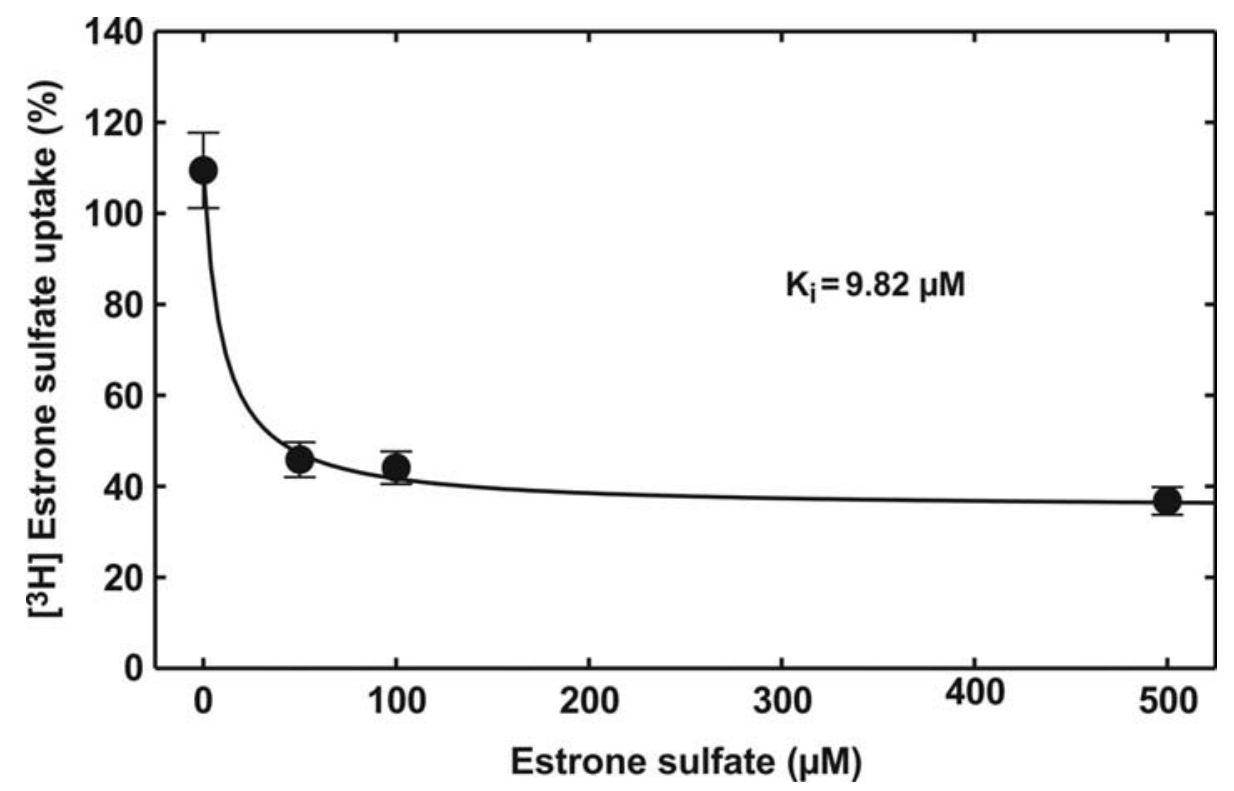

Figure 4.27 Inhibition of $\left[{ }^{3} \mathrm{H}\right]$ estrone sulfate uptake into forskolin pre-stimulated $\mathrm{NCl}$ H295R by unlabeled estrone sulfate. Cells were pre-stimulated for $24 \mathrm{~h}$ with forskolin, washed, and incubated for $10 \mathrm{~min}$ with $\left[{ }^{3} \mathrm{H}\right]$ estrone sulfate $(0.44 \mu \mathrm{Ci} / \mathrm{ml}, 10 \mathrm{nM})$, in the presence or absence of different concentrations of unlabeled estrone sulfate. Each column is calculated as percentage of $\left[{ }^{3} \mathrm{H}\right]$ estrone sulfate uptake of forskolin pre-stimulated cells $(100 \%)$ measured in the absence of estrone sulfate within the same experiment. Data represent means \pm SEM of five independent experiments with 3 wells per condition in each experiment. The $\mathrm{K}_{i}$ value was calculated according to the Hill equation using SigmaPlot 2001.

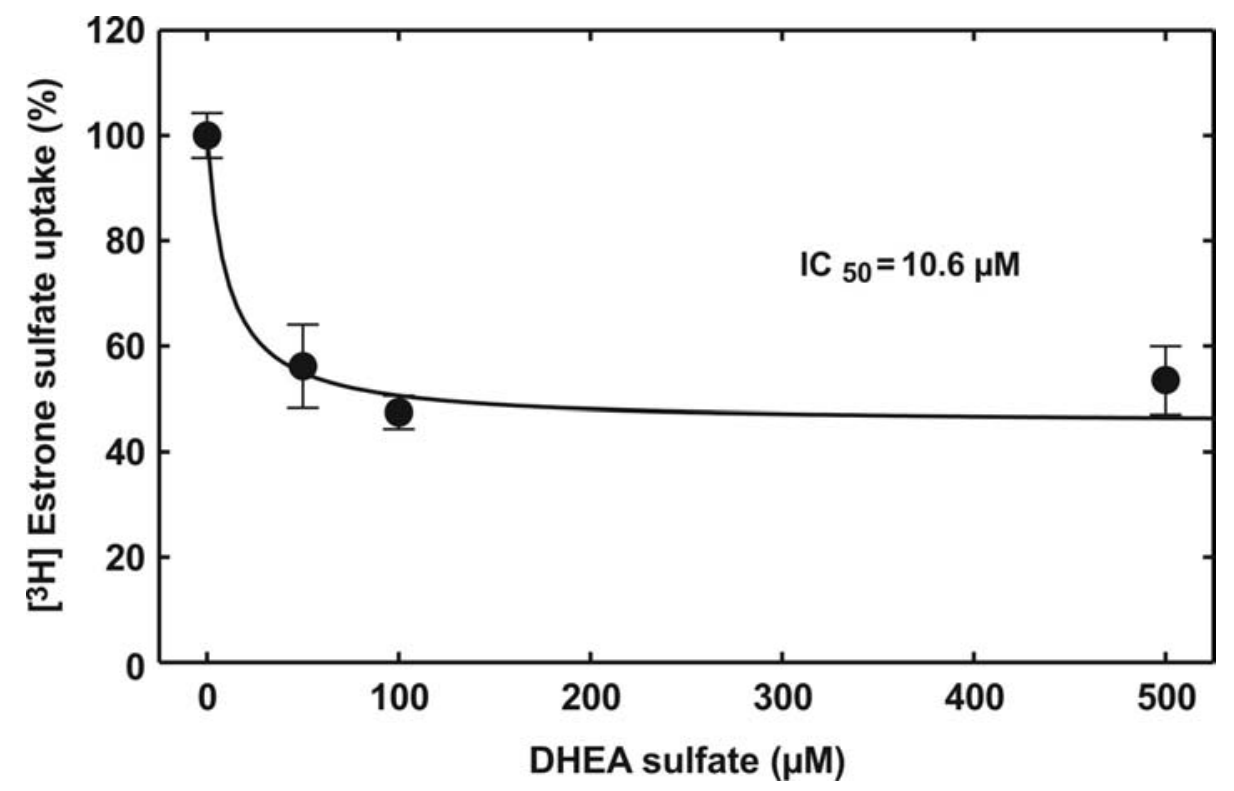

Figure 4.28 Inhibition of $\left[{ }^{3} \mathrm{H}\right]$ estrone sulfate uptake into forskolin pre-stimulated $\mathrm{NCl}$ H295R by unlabeled DHEAS. Cells were pre-stimulated for $24 \mathrm{~h}$ with forskolin, washed, and incubated for $10 \mathrm{~min}$ with $\left.{ }^{3} \mathrm{H}\right]$ estrone sulfate $(0.44 \mu \mathrm{Ci} / \mathrm{ml}, 10 \mathrm{nM})$, in the presence or absence of different concentrations of unlabeled DHEAS. Each column is calculated as percentage of $\left[^{3} \mathrm{H}\right]$ estrone sulfate uptake of forskolin pre-stimulated cells $(100 \%)$ measured in the absence of DHEAS within the same experiment. Data represent means \pm SEM of more then five independent experiments with 3 wells per condition in each experiment. The $\mathrm{IC}_{50}$ value was calculated according to Hill equation using SigmaPlot 2001. 


\subsubsection{Inhibition of $\left[{ }^{3} \mathrm{H}\right]$ estrone sulfate uptake into $\mathrm{NCl}-\mathrm{H} 295 \mathrm{R}$ cells by cortisol}

Cortisol is a major product of $\mathrm{NCl}-\mathrm{H} 295 \mathrm{R}$ cells under forskolin stimulation (Rainey et al. 1994). To clarify that both cortisol and estrone sulfate might be sharing the same transporter for their translocation, we checked the inhibitory effect of unlabeled cortisol on the $\left[{ }^{3} \mathrm{H}\right]$ estrone sulfate uptake into $\mathrm{NCl}-\mathrm{H} 295 \mathrm{R}$ cells. Different concentrations of unlabeled cortisol were added for this purpose to the uptake medium. As shown in figure 4.29, cortisol showed a dose dependent inhibition of $\left[{ }^{3} \mathrm{H}\right]$ estrone sulfate uptake into $\mathrm{NCl}-\mathrm{H} 295 \mathrm{R}$ cells. The calculated $\mathrm{IC}_{50}$ of unlabeled cortisol for $\left[{ }^{3} \mathrm{H}\right]$ estrone sulfate uptake in $\mathrm{NCl}-\mathrm{H} 295 \mathrm{R}$ cells was $38.9 \mu \mathrm{M}$.

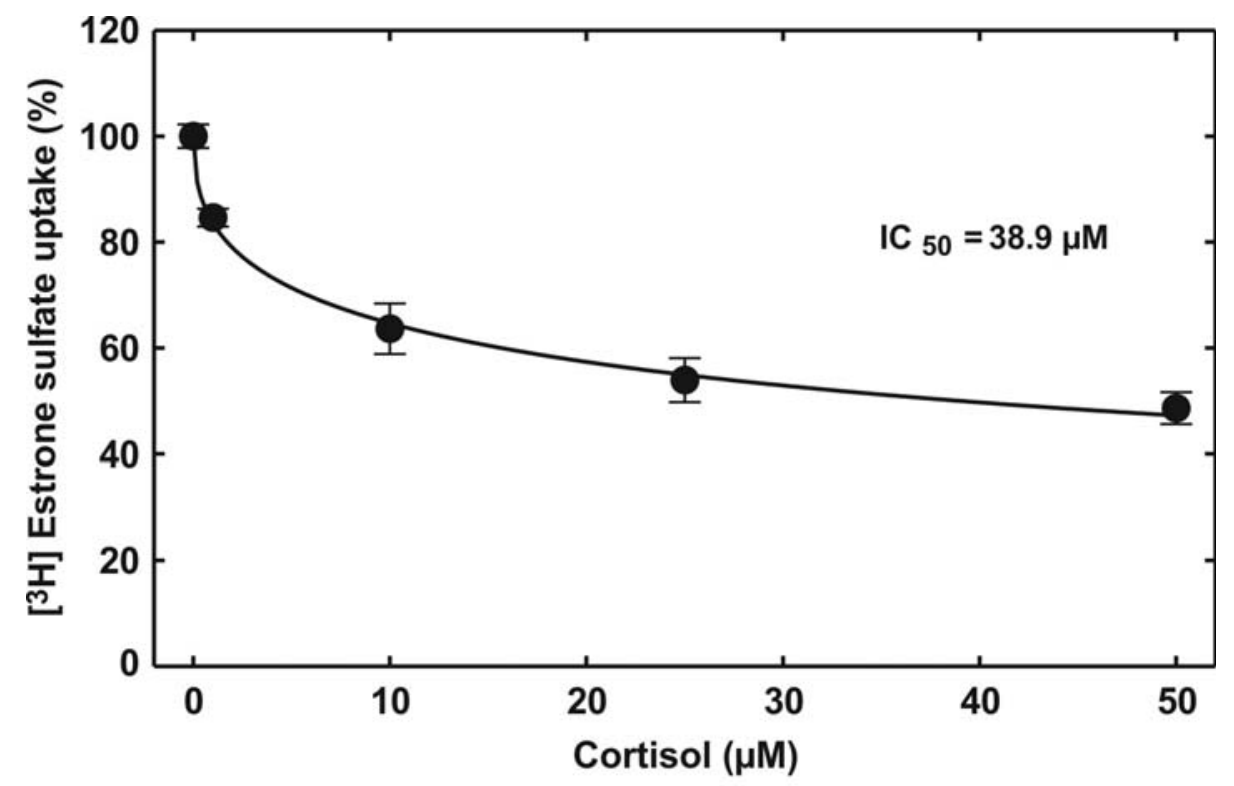

Figure 4.29 Inhibition of $\left[{ }^{3} \mathrm{H}\right]$ estrone sulfate uptake into forskolin pre-stimulated $\mathrm{NCl}$ H295R by cortisol. Cells were pre-stimulated for $24 \mathrm{~h}$ with forskolin, washed, and incubated for $10 \mathrm{~min}$ with $\left[{ }^{3} \mathrm{H}\right]$ estrone sulfate $(0.44 \mu \mathrm{Ci} / \mathrm{ml}, 10 \mathrm{nM})$, in the presence or absence of different concentrations of cortisol. Each column is calculated as percentage of $\left[{ }^{3} \mathrm{H}\right]$ estrone sulfate uptake of forskolin pre-stimulated cells $(100 \%)$ measured in the absence of cortisol within the same experiment. Data represent means \pm SEM of five independent experiments with 3 wells per condition in each experiment. The $\mathrm{IC}_{50}$ value was calculated according to the Hill equation using SigmaPlot 2001

\subsubsection{Inhibition of $\left[{ }^{3} \mathrm{H}\right]$ estrone sulfate uptake into $\mathrm{NCI}-\mathrm{H} 295 \mathrm{R}$ cells by inhibitors of the OAT family}

Probenecid is a potent inhibitor of the organic anion transporter family. Different concentrations of probenecid showed dose dependent inhibition of $\left[{ }^{3} \mathrm{H}\right]$ estrone sulfate uptake into $\mathrm{NCl}-\mathrm{H} 295 \mathrm{R}$ cells. The presence of $10 \mu \mathrm{M}$ probenecid reduced 
the uptake of $\left[{ }^{3} \mathrm{H}\right]$ estrone sulfate to $81.5 \pm 3.8 \%(P<0.005)$, figure 4.30 . Inhibition was increased with increasing the concentration of probenecid. The $\left[{ }^{3} \mathrm{H}\right]$ estrone sulfate uptake in the presence of $0.01 \mathrm{mM}, 0.1 \mathrm{mM}, 0.5 \mathrm{mM}$ and $1 \mathrm{mM}$ probenecid was $78.5 \pm 5.7 \%(P<0.001), 73.3 \pm 5.3 \%(P<0.0005), 57.4 \pm 4.2 \%(P<0.0001)$, and $48.6 \pm 3.6 \%(P<0.0001)$, respectively, as compared to $100 \%$ forskolin treated $\mathrm{NCl}-\mathrm{H} 295 \mathrm{R}$ cells.

Cimetidine is another inhibitor of hOAT3 and its lower doses $(10 \mu \mathrm{M})$ effectively reduced the $\left[{ }^{3} \mathrm{H}\right]$ estrone sulfate to $68.2 \pm 5.6 \%(P<0.0001)$ in comparison to $100 \%$ in forskolin stimulated cells. Higher doses of cimetidine did not increase significantly the inhibition of $\left[{ }^{3} \mathrm{H}\right]$ estrone sulfate uptake. The $\left[{ }^{3} \mathrm{H}\right]$ estrone sulfate uptake at 0.01 $\mathrm{mM}, 0.1 \mathrm{mM}, 0.5 \mathrm{mM}$, and $1 \mathrm{mM}$ were $63.0 \pm 5.4 \%(\mathrm{P}<0.0001), 63.1 \pm 3.7 \%(\mathrm{P}<$ $0.0001), 55.8 \pm 3.0 \%(P<0.0001)$, and $56.8 \pm 4.6 \%(P<0.0001)$, respectively.

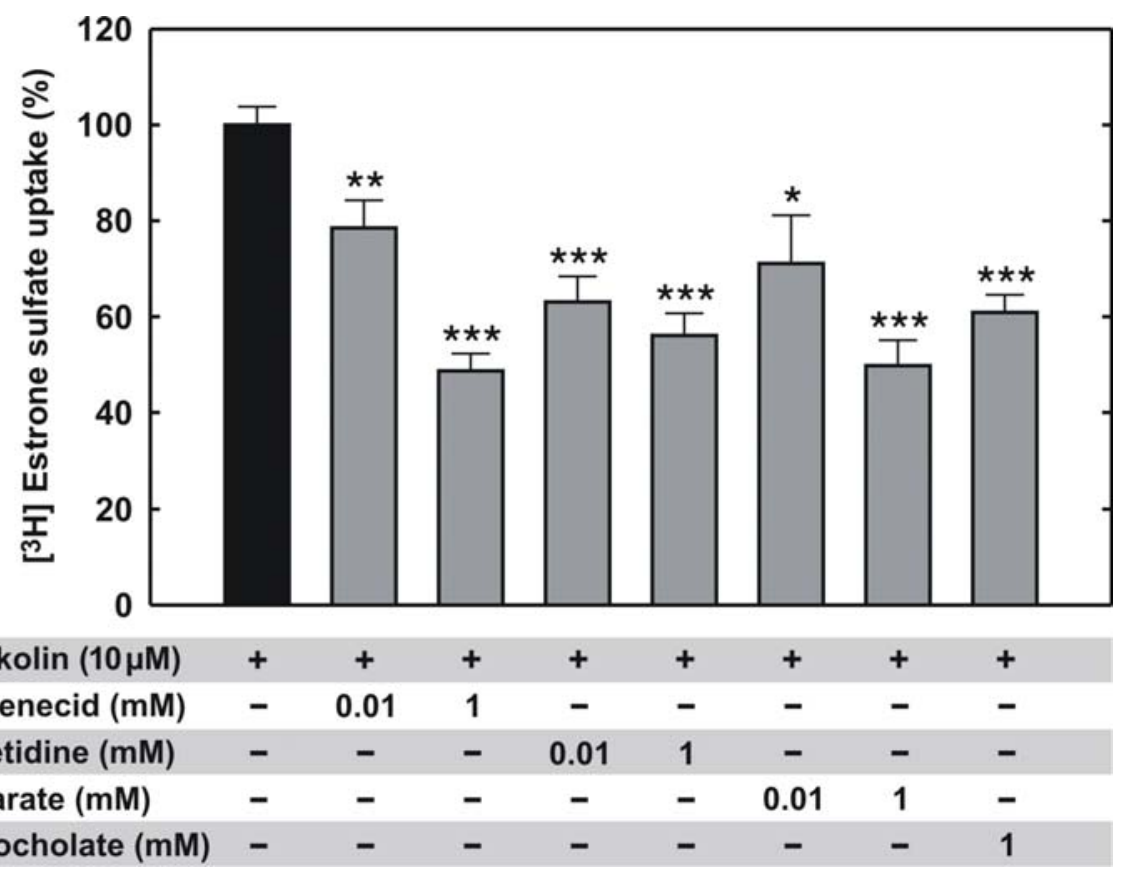

Figure 4.30 Inhibition of $\left[{ }^{3} \mathrm{H}\right]$ estrone sulfate uptake into forskolin pre-stimulated $\mathrm{NCI}$ H295R cells by inhibitors of the OAT family. Cells were pre-stimulated for $24 \mathrm{~h}$ with forskolin, washed, and incubated for $10 \mathrm{~min}$ with $\left[{ }^{3} \mathrm{H}\right]$ estrone sulfate $(0.44 \mu \mathrm{Ci} / \mathrm{ml}, 10 \mathrm{nM})$, in the presence or absence of different concentrations of probenecid, cimetidine, glutarate or taurocholate. Each column is calculated as percentage of $\left[{ }^{3} \mathrm{H}\right]$ estrone sulfate uptake of forskolin pre-stimulated cells $(100 \%)$ measured in the absence of probenecid, cimetidine, glutarate and taurocholate within the same experiment. Data represent means \pm SEM of more than four to five independent experiments with 3 wells per condition in each experiment. The significance was calculated by student's t-test against the control without probenecid, cimetidine, glutarate and taurocholate $\left({ }^{*}, \mathrm{P}<0.01 ;{ }^{* *}, \mathrm{P}<0.001 ;{ }^{* * *}, \mathrm{P}<0.0001\right)$. 
Organic anion transporters take up organic anions in exchange of Krebs-cycle intermediates like $\alpha$-ketoglutarate. To determine the cis-inhibitory effect of these intermediates, we added glutarate in the transport medium along with $\left[{ }^{3} \mathrm{H}\right]$ estrone sulfate. The results demonstrate a dose dependent cis-inhibition of $\left[{ }^{3} \mathrm{H}\right]$ estrone sulfate into $\mathrm{NCl}-\mathrm{H} 295 \mathrm{R}$ cells by glutarate. [ $\left.{ }^{3} \mathrm{H}\right]$ Estrone sulfate uptake was reduced in the presence of $0.01 \mathrm{mM}$ glutarate to $71.1 \pm 10.0 \%(P<0.01) . \quad\left[{ }^{3} \mathrm{H}\right]$ estrone sulfate was $67.6 \pm 4.1 \%(P<0.0001), 58.8 \pm 4.4 \%(P<0.0001)$, and $49.7 \pm 5.3 \%(P<$ 0.0001 ), with $0.1 \mathrm{mM}, 0.5 \mathrm{mM}$, and $1 \mathrm{mM}$ glutarate, respectively.

Taurocholate is a bile salt and transported by many OATs and OATPs. Taurocholate at concentration of $0.1 \mathrm{mM}$ did not result in a significant reduction in $\left[{ }^{3} \mathrm{H}\right]$ estrone sulfate uptake by $\mathrm{NCl}-\mathrm{H} 205 \mathrm{R}$ cells. The incubation with $0.5 \mathrm{mM}$ and $1 \mathrm{mM}$ taurocholate reduced $\left[{ }^{3} \mathrm{H}\right]$ estrone sulfate uptake to $77.3 \pm 4.3 \%(P<0.0005)$, and $60.3 \pm 3.6 \%(P<0.0001)$, respectively (Figure 4.30$)$.

\subsubsection{Trans-stimulation of $\left[{ }^{3} \mathrm{H}\right]$ estrone sulfate uptake into $\mathrm{NCl}-$ H295R cells by glutarate and cortisol}

In physiological conditions, $\alpha$-ketoglutarate is transported out of the cell by OAT1 and OAT3 in exchange of organic anions. To demonstrate that estrone sulfate uptake into $\mathrm{NCl}-\mathrm{H} 295 \mathrm{R}$ cells is carried out by hOAT3, we preloaded the cells two hours with 1 $\mathrm{mM}$ glutarate. After three washing steps, the cells were incubated with medium containing $\left.10 \mathrm{nM} \mathrm{[}{ }^{3} \mathrm{H}\right]$ estrone sulfate. The $\left[{ }^{3} \mathrm{H}\right]$ estrone sulfate uptake was carried out for one min incubation period. Glutarate preloaded cells showed $149.5 \pm 3.9 \%$ ( $\mathrm{P}<$ 0.0001 ) uptake of $\left[{ }^{3} \mathrm{H}\right]$ estrone sulfate as compared to the control set of $100 \%$ (Figure 4.31, panel A).

To clarify whether hOAT3 can mediate efflux transport of cortisol in exchange of an organic anion, we preloaded the cells for two hours with unlabeled cortisol and analysed $\left[{ }^{3} \mathrm{H}\right]$ estrone sulfate uptake. The $\left[{ }^{3} \mathrm{H}\right]$ estrone sulfate uptake by cortisolpreloaded cells was $138.8 \pm 6.0 \%(P<0.0001)$, in comparison to control $(100 \pm$ $3.8 \%$ ) (Figure 4.31, panel B). The results show that cortisol, like glutarate, can transstimulate $\left[{ }^{3} \mathrm{H}\right]$ estrone sulfate uptake by $\mathrm{NCl}-\mathrm{H} 295 \mathrm{R}$ cells. 

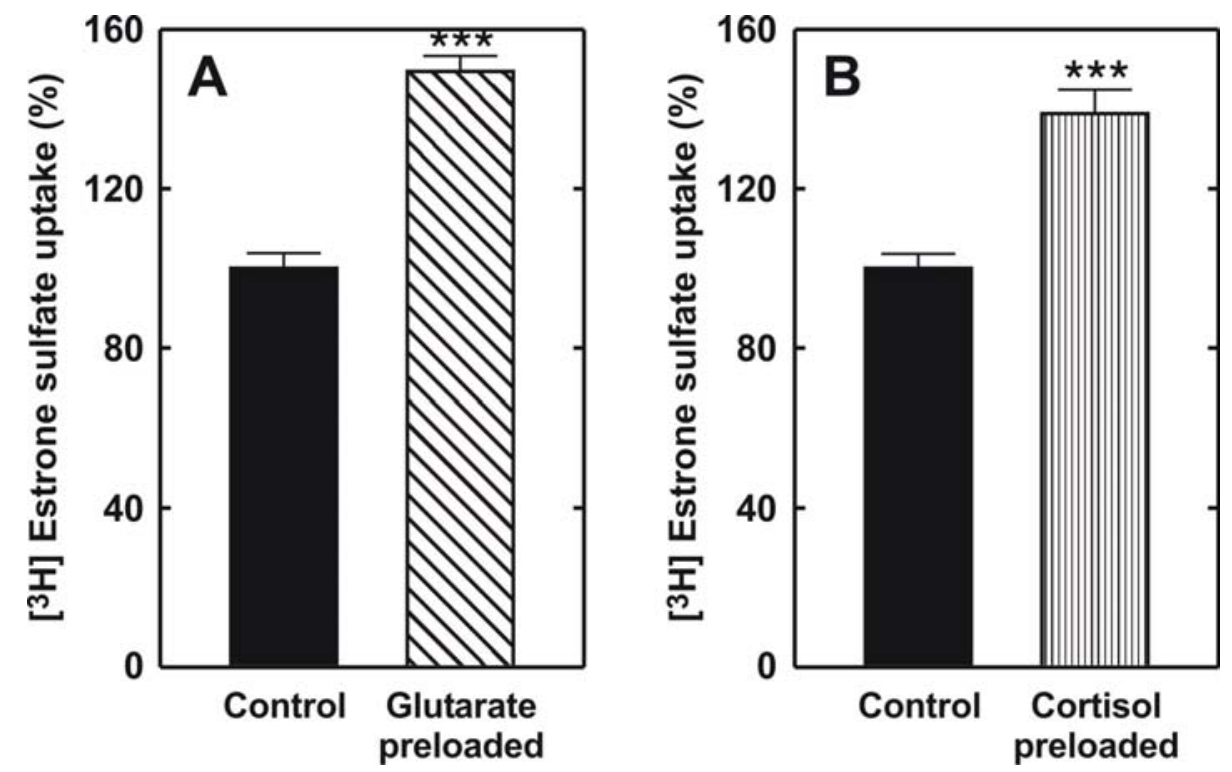

Figure 4.31 Trans-stimulation of $\left[{ }^{3} \mathrm{H}\right]$ estrone sulfate uptake into $\mathrm{NCI}-\mathrm{H} 295 \mathrm{R}$ cells by preloading with glutarate and cortisol. The cells were grown in 24 well plates at least 48 hours before start of experiment. Cells were preloaded with $1 \mathrm{mM}$ glutarate (A) or $100 \mu \mathrm{M}$ cortisol for two hours. At the end of preloading, cells were washed three times with warm Ringer solution and were incubated with $\left[{ }^{3} \mathrm{H}\right]$ estrone sulfate $(0.44 \mu \mathrm{Ci} / \mathrm{ml}, 10 \mathrm{nM})$ in Ringer solution for one min. Each column is calculated as percentage of $\left[{ }^{3} \mathrm{H}\right]$ estrone sulfate uptake of control (not preloaded) cells $(100 \%)$ from the same uptake experiment. Data represent means \pm SEM of five independent experiments with 3 wells for each experimental condition. The significance was calculated by student's t-test against the control $\left({ }^{* * *}, \mathrm{P}<0.0001\right)$.

$\mathrm{NCl}-\mathrm{H} 295 \mathrm{R}$ cells were also checked for their affinity to transport DHEAS, another substrate of hOAT3. Ten min incubation with $\left[{ }^{3} \mathrm{H}\right] \mathrm{DHEAS}$ showed highly significant radiolabel uptake into $\mathrm{NCl}-\mathrm{H} 295 \mathrm{R}$ cells. $\left[{ }^{3} \mathrm{H}\right] \mathrm{DHEAS}$ uptake could be inhibited by the following concentrations of unlabeled DHEAS: $0.1 \mathrm{mM}, 52.9 \pm 3.1 \%(P<0.0001) ; 0.5$ $\mathrm{mM}, 51.2 \pm 3.3 \%(\mathrm{P}<0.0001)$; and $1 \mathrm{mM}, 42.5 \pm 2.4 \%(P<0.0001)$, respectively.

\subsection{ROLE OF MDR1 IN CORTISOL RELEASE FROM HUMAN ADRENOCORTICAL CELLS}

Multidrug resistance P-glycoprotein (MDRI) is a member of $A B C$ transporter family (Chin et al. 1989; Gottesman et al. 1988) and probably plays a role in cortisol release. To verify the existence of MDR1 in NCl-H295R cells and adrenal tissues we performed expression and functional studies. 


\subsubsection{Expression of MDR1 in NCl-H295R cells, normal and tumor}

\section{adrenal tissues}

We checked the expression of MDRI in the $\mathrm{NCl}-\mathrm{H} 295 \mathrm{R}$ cells, normal and tumor tissue by RT-PCR. The sequence specific primers were designed for MDR1 as listed in Methods, Table 3. Expression of MDR1 was present in the cells between different passages as well as both in tumor and normal human adrenal tissues (Figure 4.32). The $\mathrm{NCl}-\mathrm{H} 295 \mathrm{R}$ cells have comparatively less MDR1 expression than human adrenal tissues, but we did not find any difference between normal and tumor adrenal tissues.

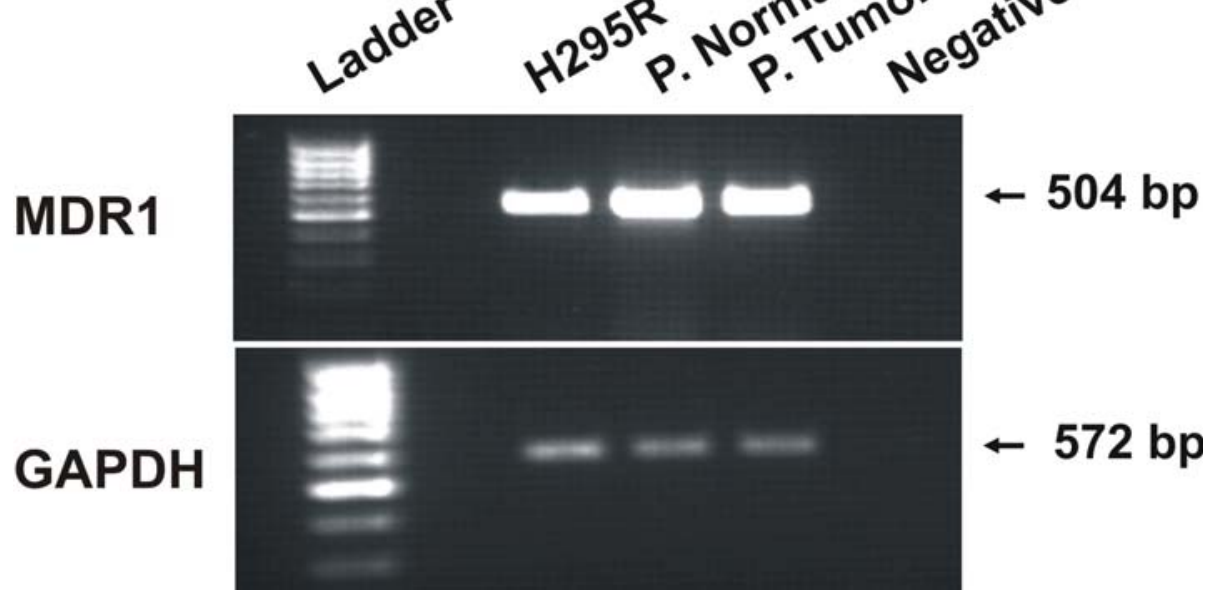

Figure 4.32 RT-PCR profiling of NCI-H295R cells, normal, and tumor adrenal tissue for MDR1 gene. Total RNA was isolated from NCl-H295R cell line, human normal adrenal tissue, and human tumor adrenal tissues. The cDNA was used as template along with the specific primers for MDR1 and GAPDH for PCR. GAPDH was used as a reference for the quantification of CDNA used for PCR.

\subsubsection{Concentration-dependent inhibitory effect of MDR1 inhibitors on cortisol release from $\mathrm{NCl}-\mathrm{H} 295 \mathrm{R}$ cells}

Since MDR1 has been reported to transport cortisol, we investigated the inhibition of cortisol release from $\mathrm{NCl}-\mathrm{H} 295 \mathrm{R}$ cells by inhibitors of MDR1, i.e. verapamil, cyclosporine A, and PSC 833. For this purpose cells were pre-stimulated for $24 \mathrm{~h}$ with $10 \mu \mathrm{M}$ forskolin. After washing with pre-warmed PBS, the cells were incubated with or without MDR1 inhibitors (verapamil or cyclosporine A) in the presence of 10 $\mu \mathrm{M}$ forskolin. At the end of a $24 \mathrm{~h}$ incubation period, medium samples were collected to determine the inhibitory effect of the substances on the cortisol release. Cortisol release from forskolin treated cells without inhibitory substances was set to $100 \%$ and the results are shown in figure 4.33. 
In the presence of $10 \mu \mathrm{M}$ verapamil cortisol release was significantly reduced to 79.7 $\pm 3.6 \%$; $(\mathrm{P}<0.001)$, while $20 \mu \mathrm{M}$ and $100 \mu \mathrm{M}$ verapamil decreased the cortisol release to $69.3 \pm 2.7 \%(P<0.0001)$, and $46.4 \pm 2.6 \%(P<0.0001)$, respectively, as compared to the forskolin stimulated control $(100 \pm 3.6 \%)$. Non-stimulated control cells showed a cortisol release of $5.8 \pm 0.3 \%(P<0.0001)$

The presence of $10 \mu \mathrm{M}$ cyclosporine $\mathrm{A}$ in the medium reduced the cortisol release from cells to $74.8 \pm 2.3 \%$; $(\mathrm{P}<0.0001)$, while by $20 \mu \mathrm{M}$ cyclosporine $A$ there was no significant additional inhibition $(71.9 \pm 4.0 \%$; $P<0.0001)$ as compared to controls $(100 \pm 3.6 \%)$.

PSC 833, another commercially available inhibitor of MDR1, reduced the cortisol release to $79.1 \pm 9.0 \%$; $(\mathrm{P}<0.01)$, and $77.5 \pm 7.3 \%$; $(\mathrm{P}<0.01)$ by $10 \mu \mathrm{M}$ and $20 \mu \mathrm{M}$ respectively, as compared to forskolin stimulated control cells $(100 \pm 3.6 \%)$ and nonstimulated cells, $(5.8 \pm 0.3 \%, P<0.0001)$.

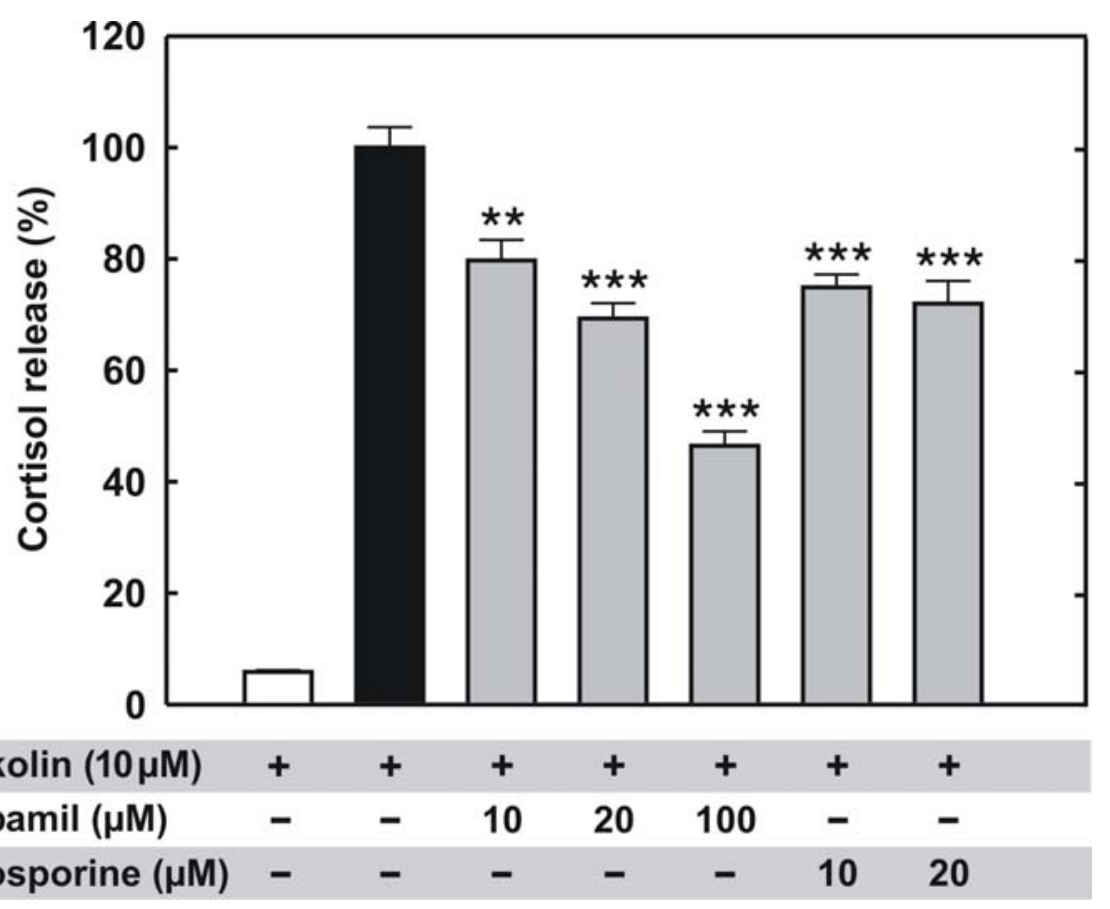

Figure 4.33 Concentration-dependent inhibitory effect of MDR1 inhibitors on cortisol release from forskolin pre-stimulated NCl-H295R cells. The cells were incubated for $24 \mathrm{~h}$ with $10 \mu \mathrm{M}$ forskolin, washed, and incubated again with medium containing $10 \mu \mathrm{M}$ forskolin, in the presence or absence of different concentrations of verapamil, PSC 833 and cyclosporine. Each column is calculated as a percentage value of cortisol release in forskolin treated cells not exposed to verapamil or PSC 833 or cyclosporine. The cortisol content of the medium was determined and normalized to the protein concentration. Data points are the means \pm SEM of values from four different experiments. The significance was performed by student's t-test against forskolin treated cells $\left({ }^{* * *}, \mathrm{P}<0.0001\right)$. 


\subsection{DHEAS INDUCED CORTISOL RELEASE FROM NCI- H295R CELLS}

Results from RT-PCR studies showed signals for human OAT3 and OAT4 in the $\mathrm{NCl}-\mathrm{H} 295 \mathrm{R}$ cells. In addition there was a fourfold greater cortisol uptake by human OAT3 and a saturable radiolabeled estrone sulfate. As estrone sulfate and DHEAS are good substrates of hOAT3, hOAT4 and OATP family members, it was worthwhile to check their effect on cortisol release from NCl-H295R cells.

\subsubsection{Effect of DHEAS and estrone sulfate on cortisol release from $\mathrm{NCl}-\mathrm{H} 295 \mathrm{R}$ cells}

Cells grown in 6 well plates were washed and incubated with or without test substances (DHEAS or estrone sulfate). At the end of a $24 \mathrm{~h}$ incubation period, medium samples were collected to determine the inhibitory effect of the test substances on the cortisol release. The results were standardized to pmol cortisol/mg protein by measuring the protein concentration of each well. As shown in the figure

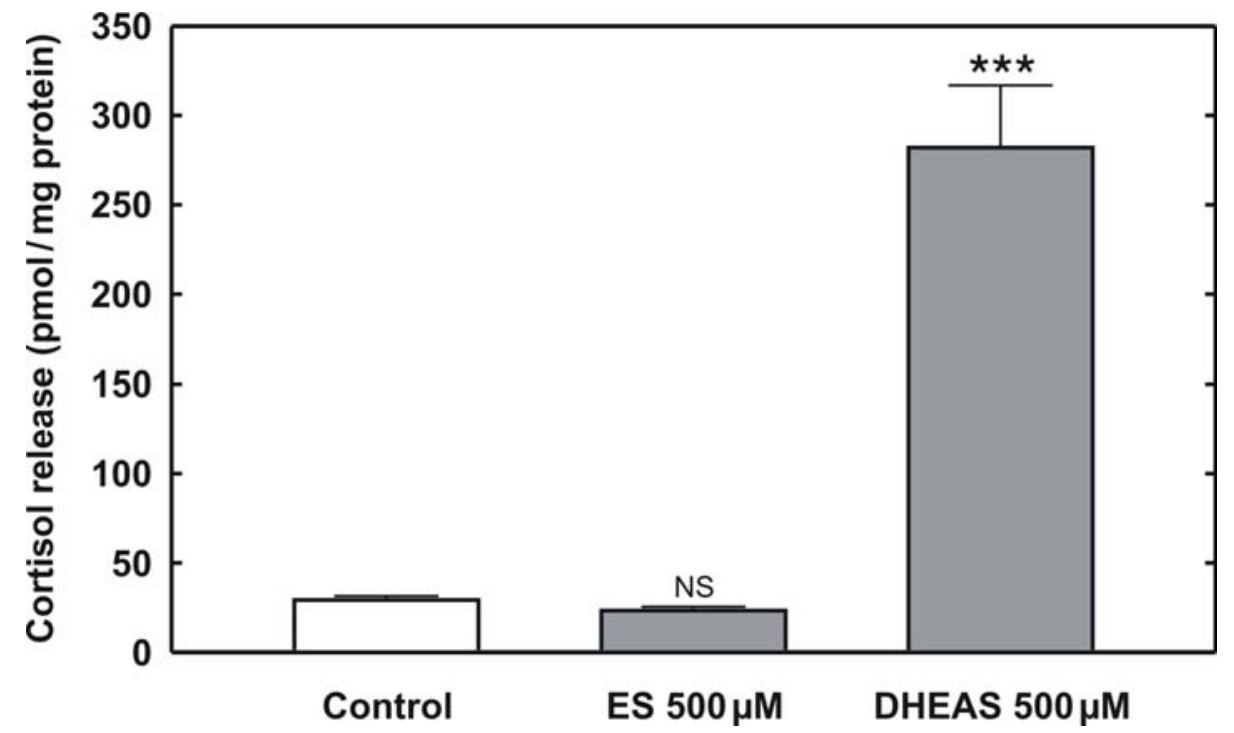

Figure 4.34 Effect of DHEAS and estrone sulfate on cortisol release by $\mathrm{NCI}-\mathrm{H} 295 \mathrm{R}$ cells. Cells were cultured in 6-well plates at least 48 hours before experiment, washed and incubated with medium in the presence or absence of $500 \mu \mathrm{M}$ estrone sulfate or $500 \mu \mathrm{M}$ DHEAS. The cortisol content of the medium was determined by RIA and normalized to the protein concentration. Each column is calculated as a percentage value of cortisol release in control cells not exposed to estrone sulfate and DHEAS. Data points are the means \pm SEM of values from three different experiments. The significance was performed by student's t-test against control cells $\left({ }^{* * *}, \mathrm{P}<0.0001\right)$. 
4.34, estrone sulfate preloading did not cause any change in cortisol release, being $23.2 \pm 2.2 \mathrm{pmol} / \mathrm{mg}$ protein as compared to the control group without any incubation which showed a cortisol release of $29.2 \pm 2.2 \mathrm{pmol} / \mathrm{mg}$ protein. The cells incubated with DHEAS revealed a 10 fold greater cortisol release $(282.0 \pm 4.8 \mathrm{pmol} / \mathrm{mg}$ protein $(P<0.0001)$ than the control group.

When different concentrations of DHEAS were incubated along with forskolin, the cortisol release was even higher than in cells treated only with forskolin (Figure 4.35). The group treated without forskolin and DHEAS showed $3.6 \pm 0.4 \%(P<0.0001)$, however, the cells treated with forskolin but without exposure to DHEAS, $100 \pm 2.6 \%$ of cortisol release. DHEAS showed effects additive to forskolin. The cortisol release in the presence of DHEAS along with forskolin was $128.5 \pm 6.9 \%(P<0.0001)$ of that in cells treated only with forskolin $(100 \pm 2.6 \%)$. The higher DHEAS concentrations $0.05 \mathrm{mM}, 0.1 \mathrm{mM}$, and $0.5 \mathrm{mM}$, showed cortisol releases of $126.3 \pm 8.4 \%(\mathrm{P}<$ $0.0005), 135.6 \pm 7.2 \%(P<0.0001)$, and $147.4 \pm 6.8 \%(P<0.0001)$, respectively. The digit increase between 0.01 and $0.5 \mathrm{mM}$ DHEAS, however, was not significant. These results indicate that DHEAS stimulates cortisol release in addition to forskolin stimulation.

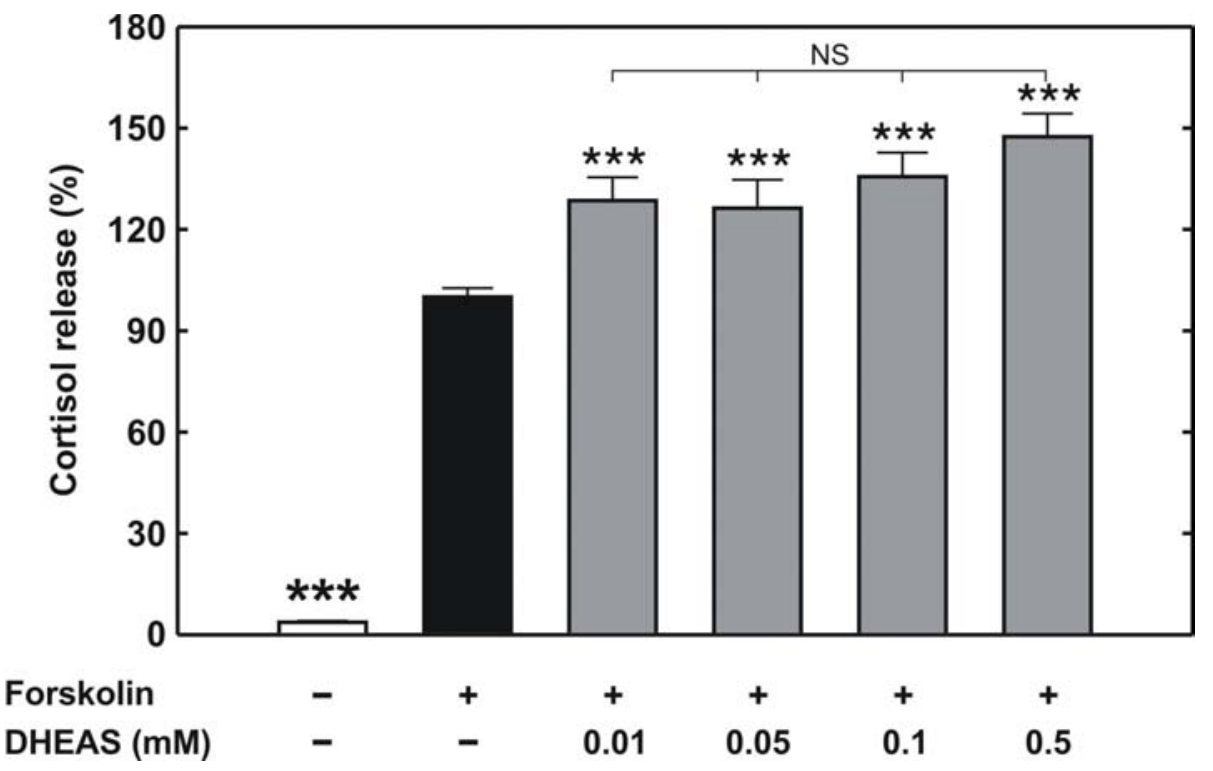

Figure 4.35 Combined effect of DHEAS and forskolin on cortisol release by NCI-H295R cells. Cells were pre-incubated with $10 \mu \mathrm{M}$ forskolin, or without forskolin (white bar) for $24 \mathrm{~h}$, washed, and incubated again with medium containing $10 \mu \mathrm{M}$ forskolin, in the presence or absence of different concentrations of DHEAS. The cortisol content of the medium was determined and normalized to the protein content. Each column is calculated as a percentage value of cortisol release in forskolin stimulated control cells not exposed to DHEAS. Data points are the means \pm SEM of values from three different experiments. The significance was performed by student's t-test against control cells $\left({ }^{* *}, P<0.0001\right)$. 


\subsection{EFFECT OF FORSKOLIN AND DHEAS STIMULATION ON MRNA EXPRESSION OF HUMAN ORGANIC ANION TRANSPORTERS}

The increase in cortisol production by forskolin and the reported increase in steroid biosynthesis enzymes (Bird et al. 1998b) made it logical to evaluate the differential expression of the organic anion transporter and organic anion transporter polypeptide mRNAs under the influence of forskolin and DHEAS in NCl-H295R cells. For this purpose mRNA expression of detected transporters was evaluated by RT-PCR in non-stimulated controls, as well as in forskolin and DHEAS stimulated $\mathrm{NCl}-\mathrm{H} 95 \mathrm{R}$ cells. GAPDH was used as reference gene from the same cDNA to standardize and compare the results.

The results shown in figure 4.38 demonstrate a rise in the expression of hOAT3 mRNA by $20 \%$ by forskolin $(P<0.07$ ), and by $50 \%$ by DHEAS $(P<0.15)$. The mRNA expression for OAT4 remained unchanged with forskolin, however there was a $37 \%(P<0.002)$ increase by DHEAS. We observed an almost steady OATP-A mRNA expression in control, forskolin, and DHEAS stimulated cells.

The following table summarize the effect of forskolin and DHEAS on mRNA expression of $\mathrm{NCl}-\mathrm{H} 295 \mathrm{R}$ cells expressed transpoter

\begin{tabular}{lcll}
\hline & Control & \multicolumn{1}{c}{ Forskolin } & \multicolumn{1}{c}{ DHEAS } \\
\hline hOAT3 & $100 \%$ & $121.1 \pm 10.0 \%(\mathrm{P}<0.07)$ & $153.3 \pm 32.4 \%(\mathrm{P}<0.15)$ \\
hOAT4 & $100 \%$ & $95.8 \pm 8.6 \%(\mathrm{P}<0.64)$ & $139.0 \pm 7.5 \%(\mathrm{P}<0.002)$ \\
OATP-A & $100 \%$ & $103.0 \pm 14.7 \%(\mathrm{P}<0.84)$ & $109.0 \pm 10.53 \%(\mathrm{P}<0.42)$ \\
MDR1 & $100 \%$ & $137.5 \pm 14.7 \%(\mathrm{P}<0.04)$ & $117.0 \pm 8.8 \%(\mathrm{P}<0.10)$
\end{tabular}

Table 4.1 Effect of forskolin and DHEAS stimulation on hOAT3, hOAT4, OATP-A, and MDR1 mRNA expression in NCl-H295R cells 
The semi-quantitative RT-PCR of controls, forskolin and DHEAS stimulated cells showed a significant increase $(37 \%$; $P<0.04)$ in MDR1 expression by forskolin. DHEAS treatment did not influence the MDR1 expression in $\mathrm{NCl}-\mathrm{H} 295 \mathrm{R}$ cells as compared to expression in non-stimulated control cells.

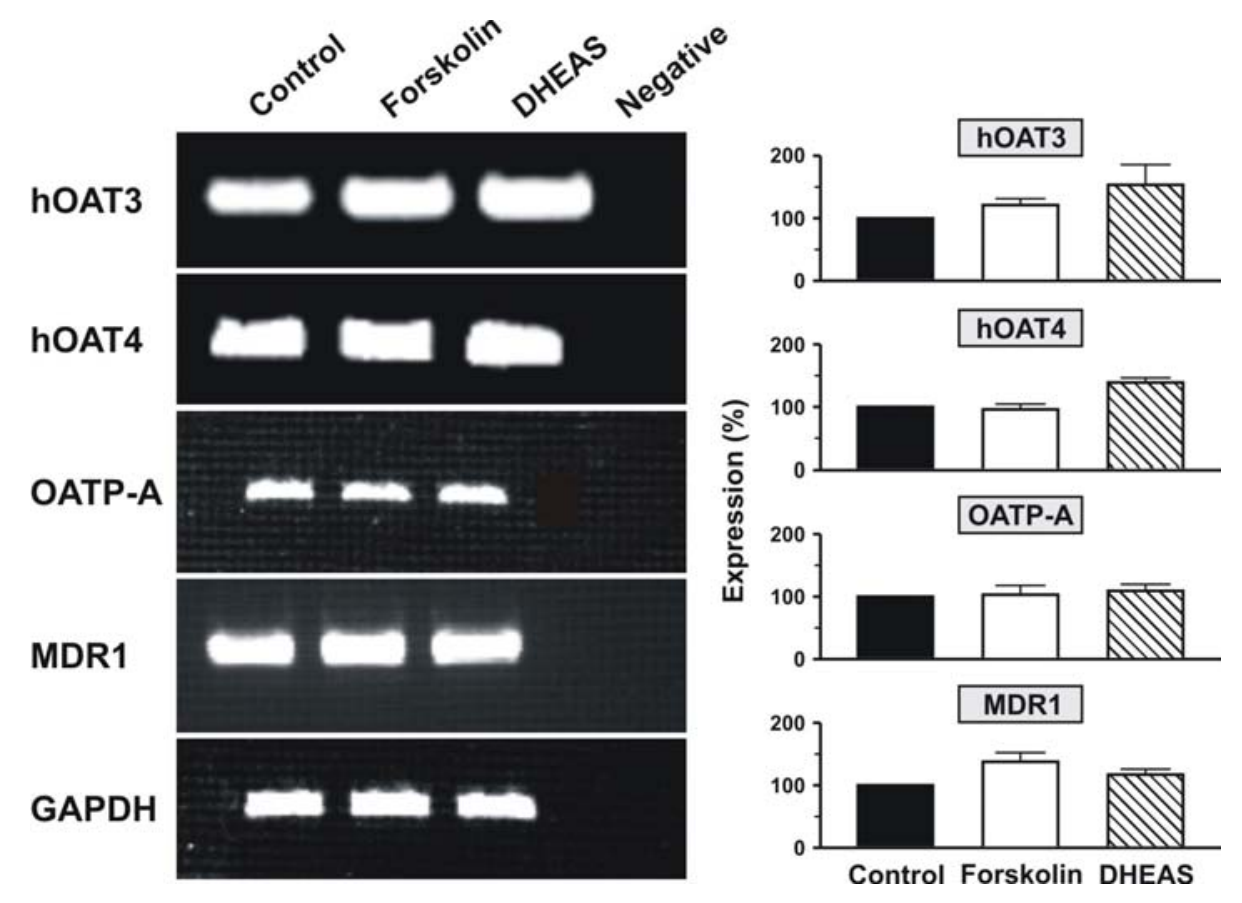

Figure 4.36 Quantitative effects of forskolin and DHEAS on mRNA expression of hOAT3, hOAT4, OATP and MDR1 in NCl-H295R cells. Cells grown in $35 \mathrm{~mm}$ Petri dishes were either incubated with medium containing $10 \mu \mathrm{M}$ forskolin or $100 \mu \mathrm{M}$ DHEAS or control medium for $24 \mathrm{~h}$. Total RNA was isolated, reverse transcribed and used as a template for PCR using OAT3, OAT4, OATP-A MDR1 and GAPDH specific primers. The figure depicts the result of one representative experiment. Similar results were obtained from mRNA isolated from four-six independent passages of $\mathrm{NCl}-\mathrm{H} 295 \mathrm{R}$ cells. The quantification was made against GAPDH as reference gene from the same cDNA to standardize and compare the results. The densitometry was made using Lablmage V 2.62 and One-Dscan V 1.0. 


\subsection{EFFECT OF FORSKOLIN AND DHEAS STIMULATION ON MRNA EXPRESSION OF KEY ENZYMES OF STEROID BIOSYNTHESIS}

In the physiological condition ACTH is known to be increase the expression of enzymes steroid biosynthesis in the adrenal cortex (Bird et al. 1998b; Engeland et al. 1997). As forskolin and DHEAS induced an increase in cortisol release, we examined their effect on mRNA expression of important enzymes of steroid biosynthesis. The specific primers for steroidogenic-acute-regulatory protein (StAR), side-chain cleavage enzyme desmolase (CYP11A1), 17 $\alpha$-hydroxylase/17,20 lyase

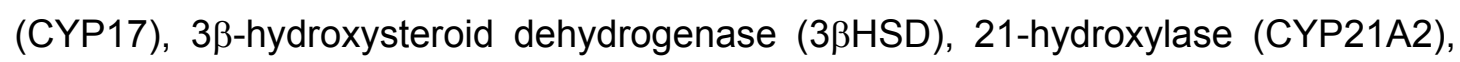
and steroid 11 -hydroxylase (CYP11B1) were used to amplify the enzyme products from cDNA of non stimulated control cells and of forskolin or DHEAS stimulated cells. The results were standardized against GAPDH gene expression.

The experiments revealed $80 \%$ increase in mRNA expression for $3 \beta \mathrm{HSD}(\mathrm{P}<$ $0.0001)$ and CYP11B1 $(P<0.08)$ by forskolin. DHEAS stimulation doubled the mRNA for CYP11B1 but the effect was not significant. The increase in 3 $\beta$ HSD was also not significant by DHEAS treatment. $24 \mathrm{~h}$ stimulation with forskolin increased the mRNA expression of StAR by $25 \%$ ( $P<0.0001)$, CYP17 by $45 \%(P<0.003)$, CYP21A2 by $55 \%(P<0.0001)$, and CYP11A1 by $13 \%(P<0.04)$. DHEAS stimulation showed a significant increase in the expression for StAR by $15 \%$ ( $P<$ 0.002). No change was observed in mRNA expression of CYP11A1, CYP17, and CYP21A2 in DHEAS-treated NCl-H295R cells. The following table summarizes the effect of forskolin and DHEAS on mRNA expression key enzymes of steroids biosynthesis in $\mathrm{NCl}-\mathrm{H} 295 \mathrm{R}$ cells 


\begin{tabular}{lcll}
\hline & Control & \multicolumn{1}{c}{ Forskolin } & \multicolumn{1}{c}{ DHEAS } \\
\hline StAR & $100 \%$ & $125.0 \pm 3.0 \%(P<0.0001)$ & $115.0 \pm 3.0 \%(P<0.03)$ \\
CYP11A1 & $100 \%$ & $113.0 \pm 4.0 \%(P<0.04)$ & $110.0 \pm 0.17 \%(P<0.52)$ \\
CYP17 & $100 \%$ & $145.0 \pm 9.0 \%(P<0.003)$ & $112.0 \pm 9.7 \%(P<0.26)$ \\
3BHSD & $100 \%$ & $180.0 \pm 5.0 \%(P<0.0001)$ & $130.0 \pm 24.0 \%(P<0.26)$ \\
CYP21A2 & $100 \%$ & $155.0 \pm 6.0 \%(P<0.0001)$ & $95.0 \pm 25.0 \%(P<0.7)$ \\
CYP11B1 & $100 \%$ & $180.0 \pm 30 \%(P<0.08)$ & $208.0 \pm 70 \%(P<0.195)$
\end{tabular}

Table 4.2 Effect of forskolin and DHEAS stimulation on key enzymes of steroid biosynthesis in $\mathrm{NCl}-\mathrm{H} 295 \mathrm{R}$ cells

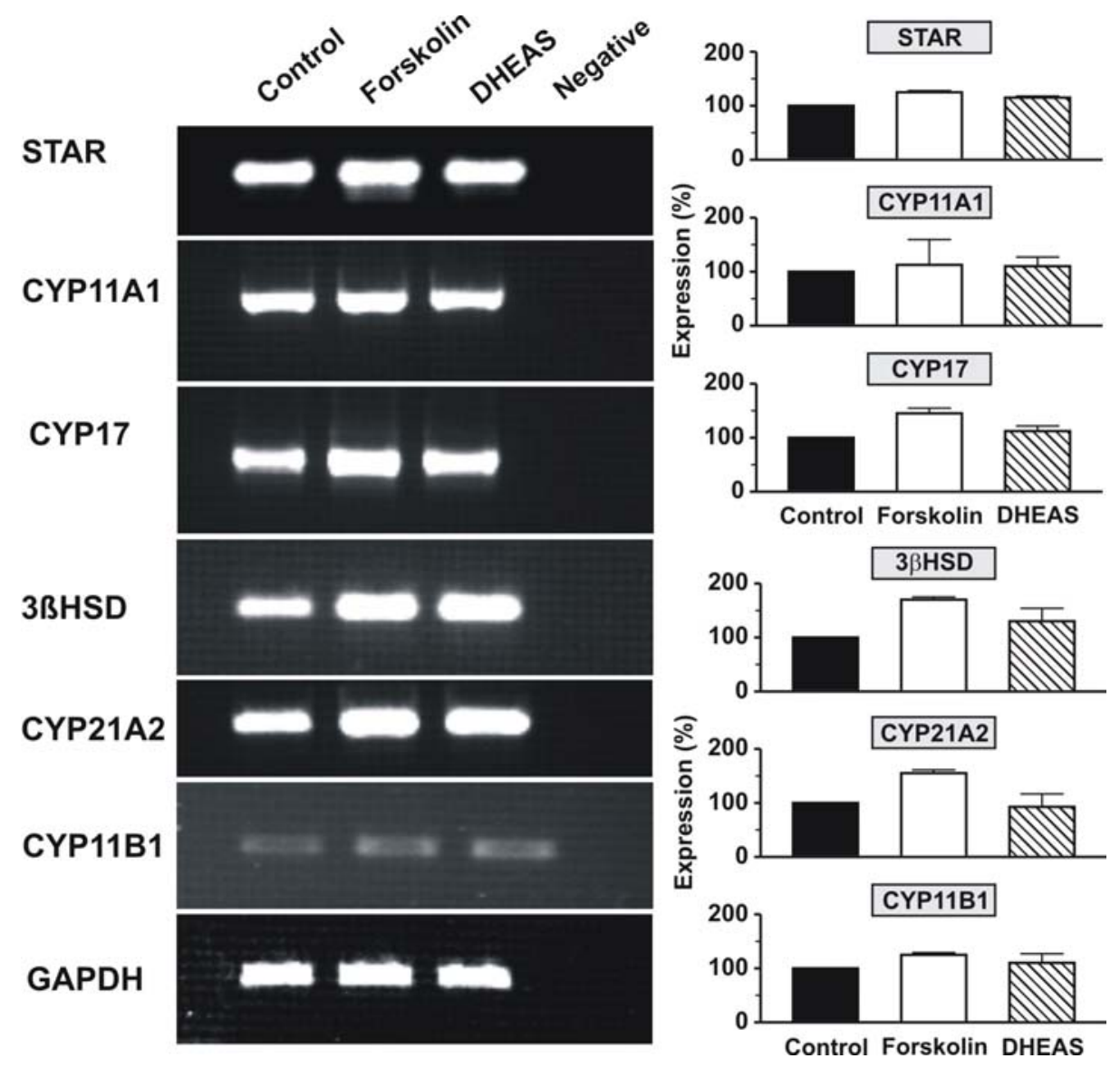

Figure 4.37 Quantitative effect of forskolin and DHEAS on mRNA expression of key steroid biosynthesis P450 enzymes in NCl-H295R cells. Cells grown in $35 \mathrm{~mm}$ Petri dishes were incubated with medium containing $10 \mu \mathrm{M}$ forskolin or $100 \mu \mathrm{M}$ DHEAS or control medium for $24 \mathrm{~h}$. Total RNA was isolated, reverse transcribed and used as a template for PCR using StAR, CYP11A1, CYP17, 33HSD, CYP21A2, CYP11B1 and GAPDH specific primers. The figure depicts the result of one representative experiment. Similar results were obtained from mRNA isolated from four independent passages of $\mathrm{NCl}-\mathrm{H} 295 \mathrm{R}$ cells. The quantification was made against GAPDH as reference gene from the same cDNA to standardize and compare the results. The densitometry was made using Lablmage $\vee 2.62$ and One-Dscan V 1.0 (Scanalytics, Inc. USA). 


\subsection{IMMUNOBLOTTING ANALYSIS FOR hOAT3 PROTEIN EXPRESSION IN NCI-H295R CELLS}

The RT-PCR experiments showed an expression of human OAT3 in the $\mathrm{NCl}-\mathrm{H} 295 \mathrm{R}$ cells, which along with functional experiments emphasized the need to look for protein expression for hOAT3 in the NCl-H295R cells. For this purpose western blot analysis with specific antibodies for human OAT3 were performed with total cells lysate (TCL) of $\mathrm{NCl}-\mathrm{H} 295 \mathrm{R}$ cells as well as with the isolated total cell membrane (TCM). Two different antibodies were used against hOAT3; 1- rOAT3 antibody prepared by Dr. Endou, (Kyorin University School of Medicine, Tokyo, Japan) which is directed against the C-terminus, while the Alpha-Diagnostics antibody was generated against $\mathrm{N}$-terminus of rat OAT3. Both antisera recognize the human OAT3. Peptide blockage was made to confirm the specificity of antibody. Both antibodies labeled multiple bands in TCL as well on TCM blots (Figure 4.38). When the C-terminal antibody was saturated with its antigen peptide, two bands at $90 \mathrm{kDa}$ and $55 \mathrm{kDa}$ were diminished. A band of approximately $90 \mathrm{kDa}$ band was also labeled by antibody against the $\mathrm{N}$-terminus.

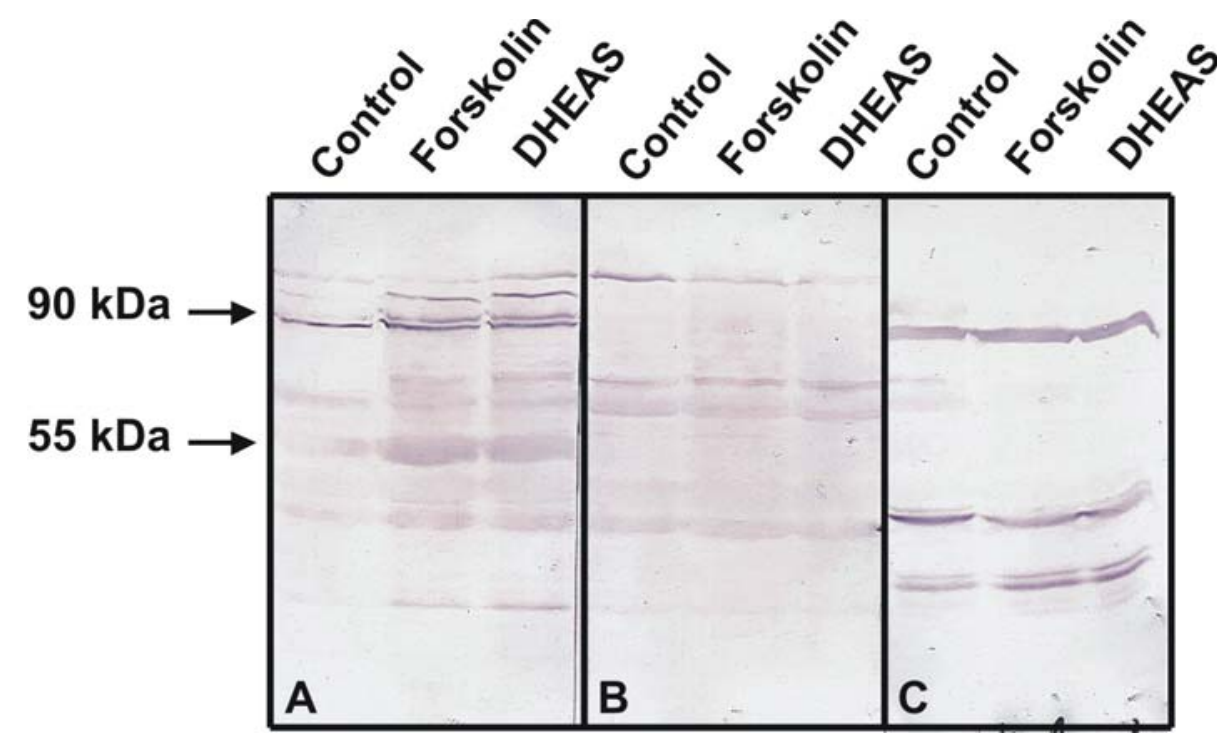

Figure 4.38 Immunoblotting of total cell lysate from NCI-H295R cells for hOAT3 protein. The cells were incubated with medium containing $10 \mu \mathrm{M}$ forskolin or $100 \mu \mathrm{M}$ DHEAS or control without stimulus for $24 \mathrm{~h}$, washed and dissolved in lysis buffer. Equal amounts of protein (total cell lysate) was loaded to each lane and reacted with (A) the C-terminal rOAT3 polyclonal antibody, (B) the C-terminal rOAT3 polyclonal antibody saturated with peptide (antigen) or (C) the $\mathrm{N}$-terminal rOAT3 polyclonal antibody. The relative intensity (\% of control) was measured by densitometry. The figure depicts the result of one representative experiment. Similar results were obtained in 3 additional experiments with different batches of TCL. 
In the next step, we examined the differential expression of hOAT3 after forskolin and DHEAS treatment of the cell. TCL results showed $221.1 \pm 45.2 \%(P<0.02)$ increase of hOAT3 expression by $24 \mathrm{~h}$ forskolin stimulation as compared to non-stimulated control $100 \%$. The DHEAS stimulation increased the expression at an almost same range as by forskolin but the analysis was not significant; $234.0 \pm 70.2 \%(P<0.08)$. Both strong signals (90 kDa and $55 \mathrm{kDa}$ ) disappeared when antibody was saturated with antigen peptide.

The hOAT3 expression in TCM sample showed greater effects by stimulation with forskolin. Forskolin induced two and half fold increase $[257.4 \pm 70.3 \%$ ( $P<0.05)]$ of hOAT3 expression over non-stimulated cells (100\%). However, DHEAS stimulation yielded $342.4 \pm 156.4 \%(P<0.15)$ as compared to non-stimulated samples.

\subsection{IMMUNOFLUORESCENCE STUDIES FOR hOAT3 PROTEIN EXPRESSION IN NCI-H295R CELLS}

In order to characterize the protein expression pattern of human OAT3 for $\mathrm{NCl}$ H295R cells, the N-terminal antibody against rOAT3 was used. The cells were stimulated with forskolin or DHEAS or without any stimulation for $24 \mathrm{~h}$ in order to study the differential expression of hOAT3.

Rat kidney slices were used as control for hOAT3 antibody, and antibodies against $\alpha$ tubulin was used to verify the cell structure as well as the experimental procedure validity. Pre-absorption to the synthetic antigen peptide was used to confirm the specificity of the antibody.

The $\alpha$-tubulin showed the labeling of the cell tubulin structure in $\mathrm{NCl}-\mathrm{H} 295 \mathrm{R}$ cells with and without treatments. There was no significant difference in the labeling of forskolin, DHEAS treated and not treated control cells. The Immunostaining also verified no structural damage and change in the cells by stimulation with forskolin or DHEAS (A), (B), and (C). There was no labeling in the absence of $\alpha$-tubulin antibody (D) 

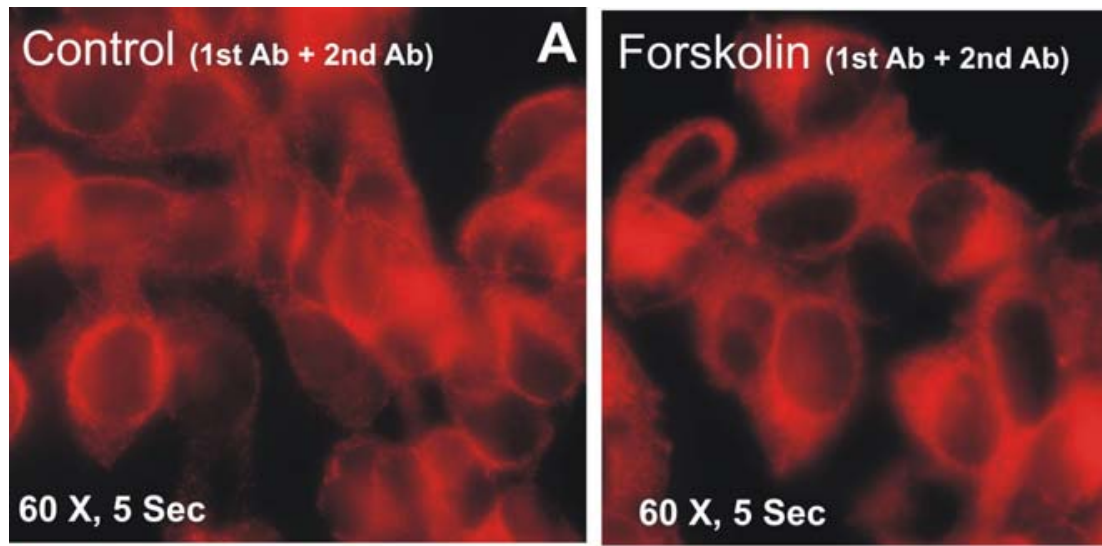

Figure 4.39 Immunostaining of $\mathrm{NCl}-\mathrm{H} 295 \mathrm{R}$ cells for $\alpha$-tubulin. The cells were $24 \mathrm{~h}$ incubated in control medium (A) or medium containing $10 \mu \mathrm{M}$ forskolin (B) or $100 \mu \mathrm{M}$ DHEAS (C). a-tubulin antibody labelling was done in all groups except group (D) where only secondary antibody was applied for unspecific staining. The Immunostaining was documented at an exposure of $60 \mathrm{X}$ magnification and for 20 seconds. The figure depicts the result of one representative experiment. Similar results were obtained in 2 additional experiments with different passages of cells.

The control group of $\mathrm{NCl}-\mathrm{H} 295 \mathrm{R}$ cells without any stimulation showed almost no labelling in the absence of first hOAT3 antibody (Figure 4.40, panel C). OAT3 antibody resulted in a significant labelling of cells (A). The specific labelling was diminished when hOAT3 antibody saturated with antigen peptide was applied (B). 

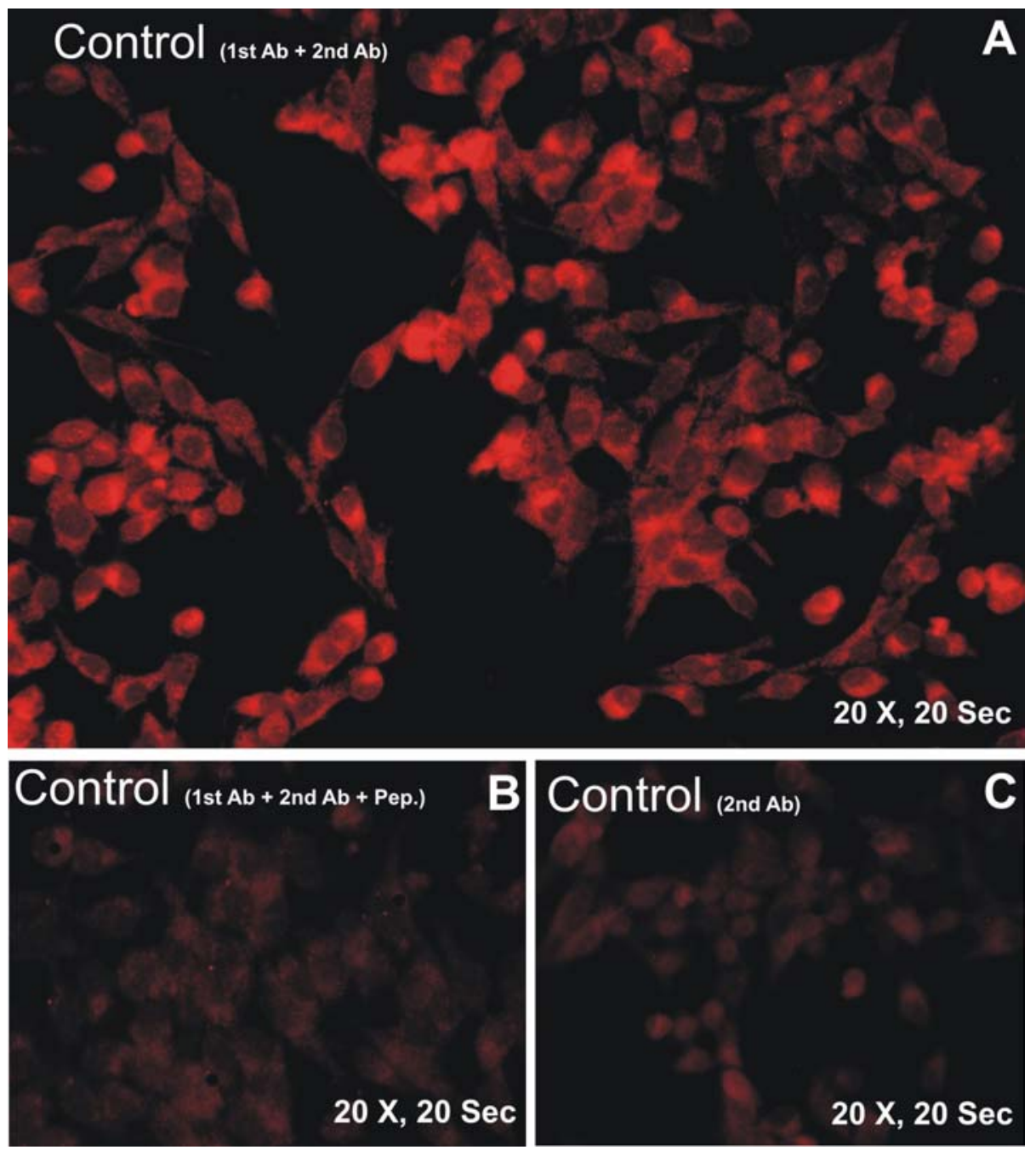

Figure 4.40 Immunostaining of non-stimulated NCI-H295R cells for human OAT3. Cells grown in $1 \mathrm{~cm} \varnothing$ slides were incubated with control medium. The immunostaing for OAT3 localization was performed with the C-terminal rat OAT3 antibody (A), and antibody saturated with antigen peptide $(B)$ and only secondary antibody was applied for unspecific staining (C). The Immunostaining was documented at an exposure of 20X magnification and for 20 seconds. The figure depicts the result of one representative experiment. Similar results were obtained in 4 additional experiments with different passages of cells.

The labelling was higher in the $24 \mathrm{~h}$ forskolin stimulated cells (Figure 4.41, panel A). Even a 40 times shorter exposure time ( 0.5 as compared to $20 \mathrm{~s}$ exposure in nonstimulated cells in figure 4.40) showed a marked increase in the OAT3 labelling by forskolin stimulated cells. The signals were completely blocked by use of antigen peptide-saturated antibody (Figure 4.41, panel B), confirming the specificity of labelling. Twenty-four hours forskolin stimulated cells also did not show any significant labelling when no hOAT3 antibody was used (Figure 4.41, panel C). 

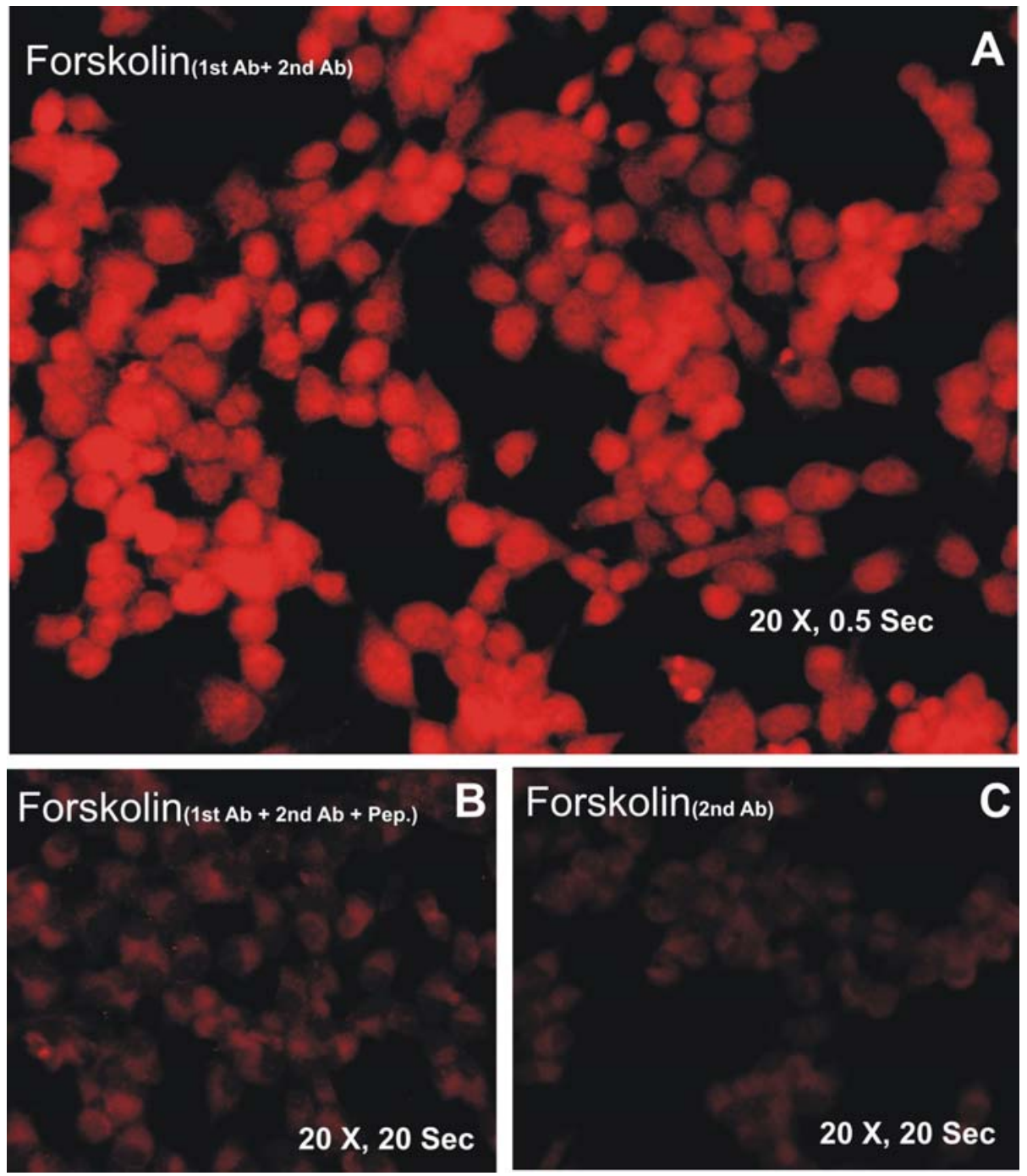

Figure 4.41 Immunostaining of OAT3 in forskolin-treated NCI-H295R cells. Cells grown in $1 \mathrm{~cm} \varnothing$ slides were stimulated $24 \mathrm{~h}$ medium containing $10 \mu \mathrm{M}$ forskolin. The immunostaining for OAT3 localization was performed with the C-terminus rat OAT3 antibody (A), and antibody saturated with antigen peptide (B) and only secondary antibody was applied for unspecific staining (C). The Immunostaining was documented at exposure time indicated on the slides. The figure depicts the result of one representative experiment. Similar results were obtained in 4 additional experiments with different passages of cells.

The treatment of $\mathrm{NCl}-\mathrm{H} 295 \mathrm{R}$ cells for $24 \mathrm{~h}$ with DHEAS yielded almost the same results as with forskolin, but with lower signal intensity. There was no reportable signal in the absence of OAT3 antibody (Figure 4.42, panel C). However, the signals for hOAT3 were high when the hOAT3 antibody was used before the secondary antibody (Figure 4.42, panel A). The pictures were recorded at two seconds 
exposure time. When the antibody was blocked with peptide, no significant labeling was observed, even at a twenty times higher exposure interval (Figure 4.42, panel B).
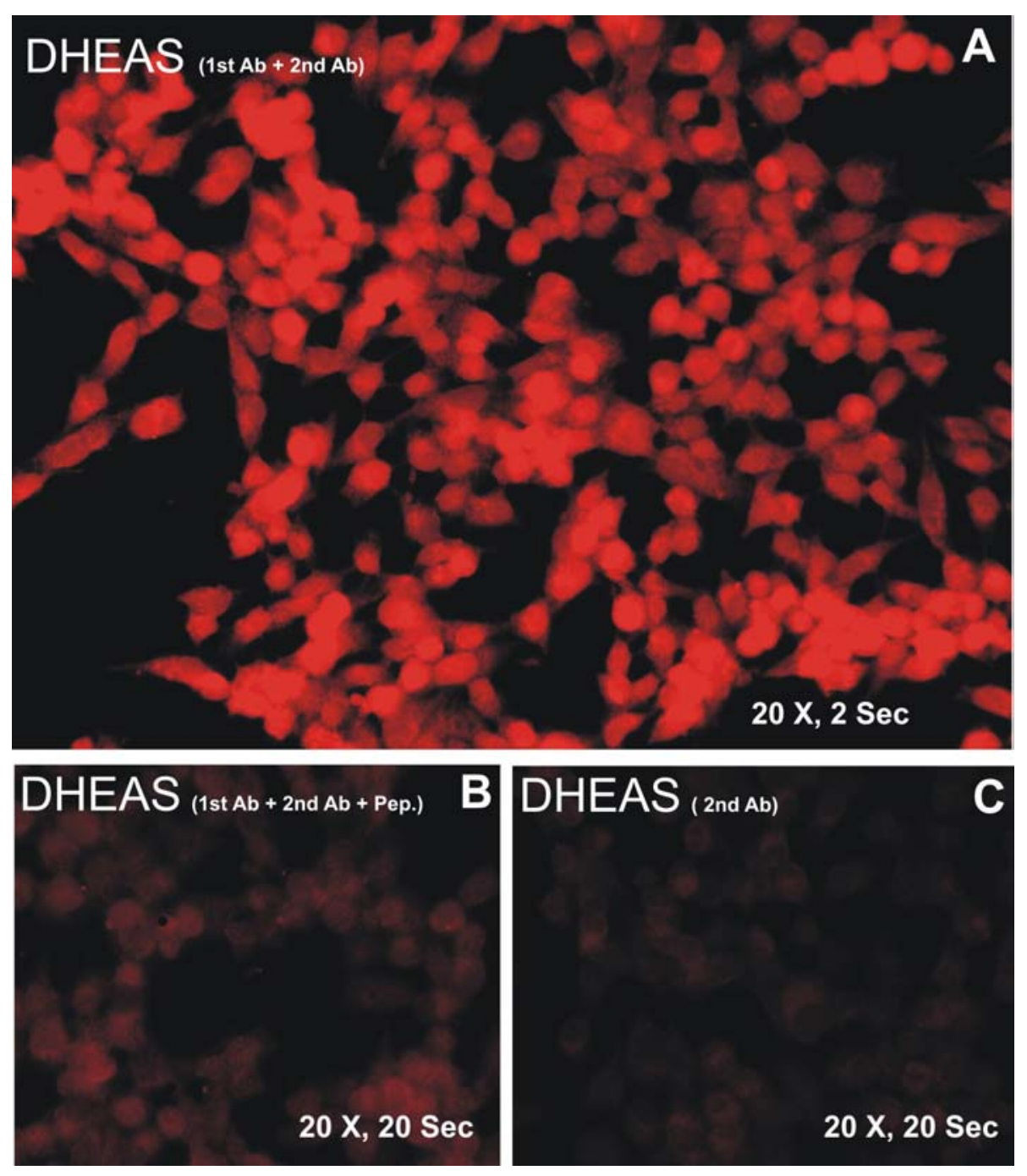

Figure 4.42 Immunostaining of OAT3 in DHEAS-treated NCI-H295R cells. Cells grown in $1 \mathrm{~cm} \varnothing$ slides were stimulated $24 \mathrm{~h}$ in medium containing $100 \mu \mathrm{M}$ DHEAS. The immunostaining for OAT3 localization was done with the C-terminus rat OAT3 antibody (A), and antibody saturated with antigen peptide (B) and only secondary antibody was applied for unspecific staining $(C)$. The Immunostaining was documented at exposure time indicated on the slides. The figure depicts the result of one representative experiment. Similar results were obtained in 4 additional experiments with different passages of cells. 


\subsection{SELDI-TOF ANALYSIS OF NCI-H295R CELLS}

The initial work with TCL, TCM and cytosol fractions was done to compare the quality of the fractions. Each fraction was spotted on the hydrophobic $\mathrm{H}-50$ ProteinChip under the same conditions. The SELDI analysis was performed to evaluate the fractionated proteins. The comparative results showed a clear, reproducible and specific pattern of cytosol and TCM enriched fraction (Figure 4.43). There appeared to be no significant protein shared by both fractions. The spectra generated from TCL retain nearly all protein signals present in the cytosol and TCM fraction.

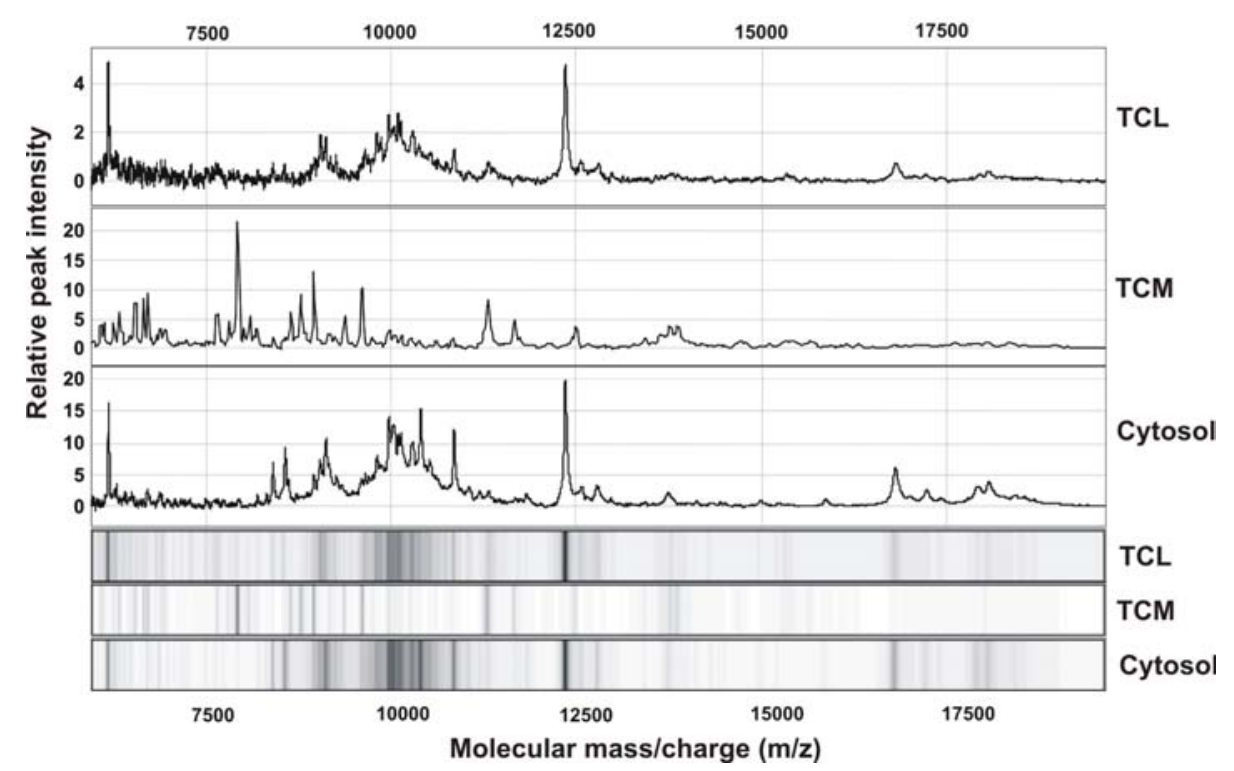

Figure 4.43 Comparison of proteins between TCL, cytosol and TCM fraction of NCIH295R cells by SELDI-TOF. The TCL, TCM, and cytosol fractions were spotted on the H-50 ProteinChip array and after washing were analysed by SELDI-TOF. The profile pattern from $\mathrm{m} / \mathrm{z} 6,000$ to 19,000 is shown. The gel-based profiles are also shown as an alternative data presentation mode. The figure depicts the result of one representative experiment. Similar results were obtained in 4 additional experiments with different passages of cells. Data was analyzed by using ProteinChip Software V 3.0 (Ciphergen, USA), (TCL; total cell lysate, TCM; total cell membrane).

In the next step the cytosol and TCM fraction were compared for the differential expression of proteins under the influence of $24 \mathrm{~h}$ stimulation with forskolin, DHEAS, or without any stimulation as control. The stimulated and non-stimulated fractions were compared to each other, i.e. cytosol to cytosol and TCM to TCM. Only hydrophobic $\mathrm{H} 50$ ProteinChips were used to analyse the hydrophobic proteins of $\mathrm{NCl}-\mathrm{H} 295 \mathrm{R}$ cells. After making SELDI analysis, the data were processed and examined on standard Ciphergen Protein-Chip software version 3.0. 
The comparison between the forskolin, DHEAS stimulated and non-stimulated control cells did not show any extra protein induced by the stimulation (Figure 4.44). However, the significant changes in the intensity of the peaks (proteins), were induced by forskolin and DHEAS stimulation. The stimulation with forskolin resulted in a higher intensity in the signals for proteins with mass to charge ratio $(\mathrm{m} / \mathrm{z}) 6179$ and 12351. DHEAS increased the intensity of the protein with $\mathrm{m} / \mathrm{z} 10097$. The protein with $\mathrm{m} / \mathrm{z} 16804$ was slightly increased in both forskolin and DHEAS stimulated cytosol fraction as compared to non-stimulated control.

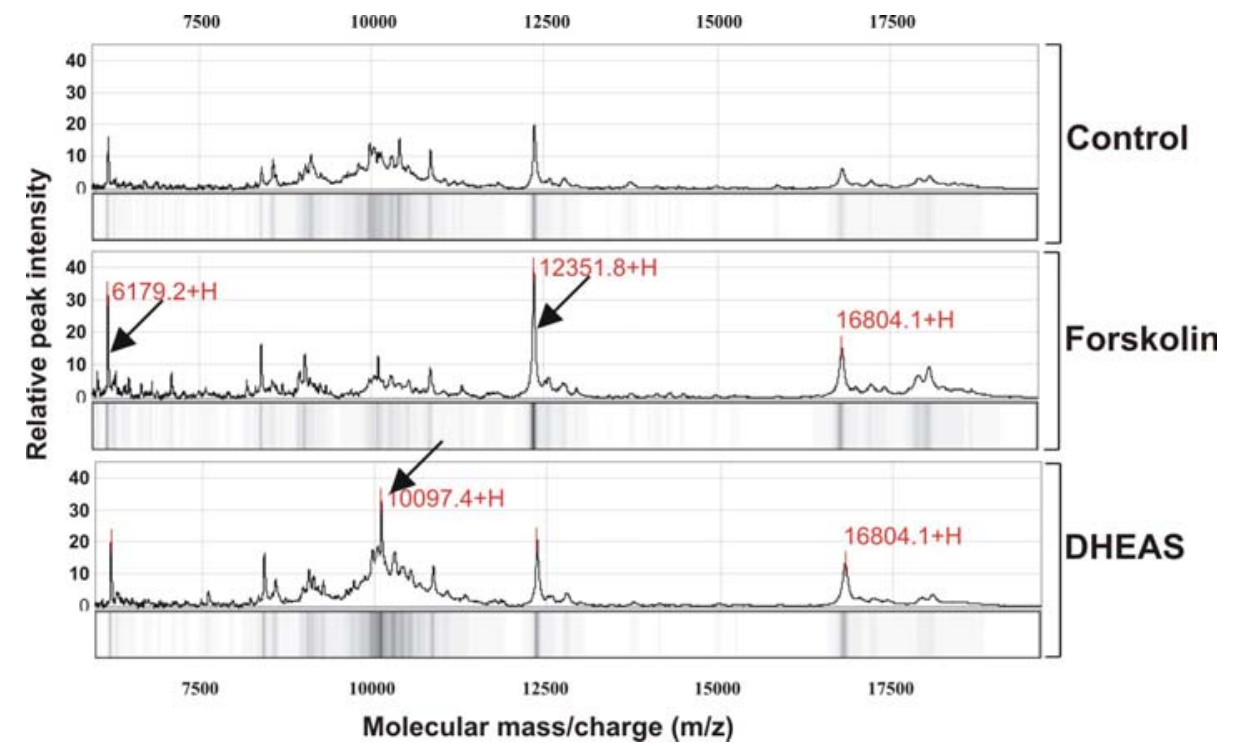

Figure 4.44 Effect of forskolin and DHEAS stimulation on expression of the cytosol proteins in $\mathrm{NCl}-\mathrm{H} 295 \mathrm{R}$ cells. The equal protein load of cytosol fractions from $24 \mathrm{~h}$ forskolin, DHEAS stimulated or non-stimulated control was spotted on the H-50 ProteinChip array and analysed by SELDI-TOF under the same conditions. The protein patterns from $\mathrm{m} / \mathrm{z} 6,000$ to 19,000 is shown. The arrows indicate the proteins changed by forskolin and DHEAS stimulation. The figure depicts the result of one representative experiment. Similar results were obtained in 4 additional experiments with different passages of cells. The measurements were conducted as described in methods and data was analyzed by using ProteinChip Software V 3.0 (Ciphergen, USA).

The comparison between the TCM fractions of the NCl-H295R cells also did not show an induction of any new protein (Figure 4.45). Many proteins changed their expression under the stimulation of forskolin and DHEAS as compared to the non- 
stimulated control TCM. Twenty four hours forskolin stimulation increased the intensity of proteins with $\mathrm{m} / \mathrm{z} 6549,6943,11307,13778$, and 15334 , while there was a slight decrease in the intensity of the protein $\mathrm{m} / \mathrm{z} 7936$ after stimulation with forskolin and DHEAS. The DHEAS stimulation did not show any further change in the intensity of proteins as compared to non stimulated (control) TCM.

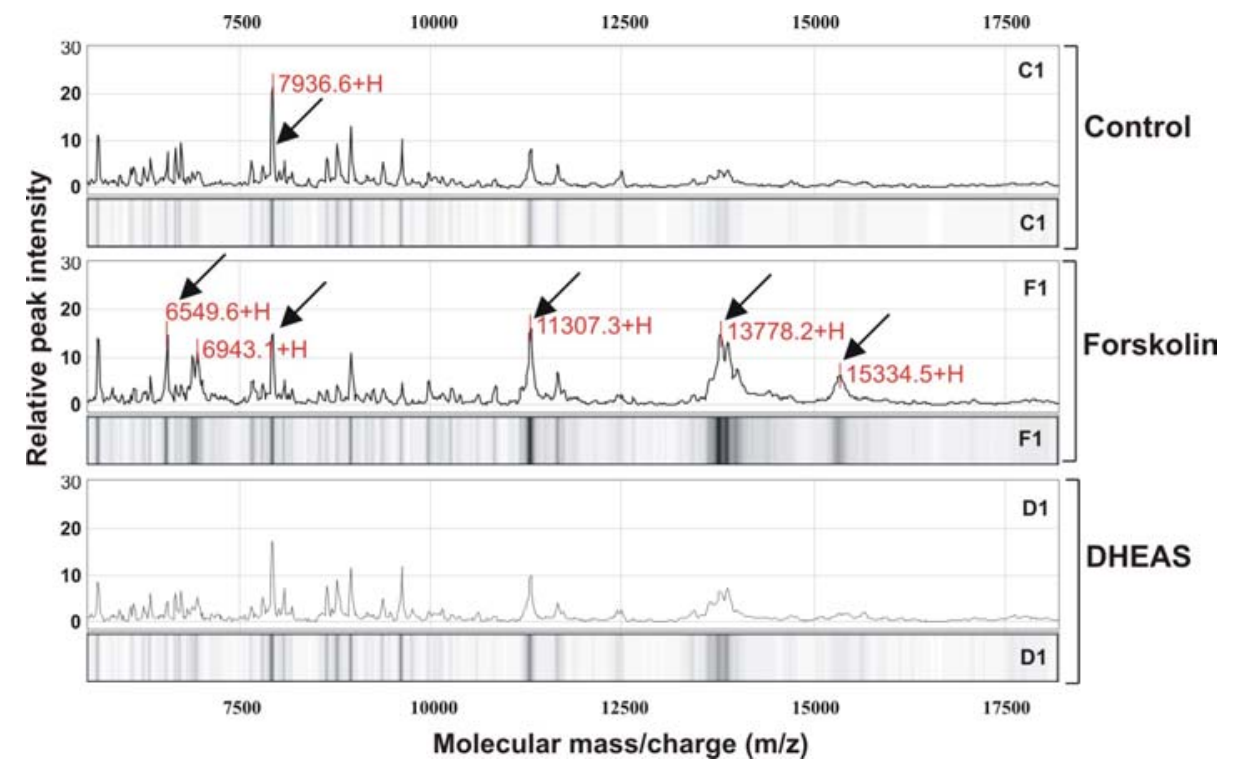

Figure 4.45 Effect of forskolin and DHEAS stimulation on expression of TCM protein in NCl-H295R cells. The equal protein load of cytosol fractions from $24 \mathrm{~h}$ forskolin, DHEAS stimulated or non-stimulated control was spotted on the H-50 ProteinChip array and analysed by SELDI-TOF under the same conditions. The protein patterns from $\mathrm{m} / \mathrm{z} 6,000$ to 19,000 is shown. The arrows indicate the proteins changed by forskolin and DHEAS stimulation. The figure depicts the result of one representative experiment. Similar results were obtained in 4 additional experiments with different passages of cells. The measurements were conducted as described in methods and data was analyzed by using ProteinChip Software V 3.0 (Ciphergen, USA). 


\subsection{MALDI-TOF ANALYSIS OF NCI-H295R CELLS}

The membrane enriched fraction, TCM was analysed through MALDI-TOF for the differential expression of transporter and cytochrome P450 enzyme proteins under the influence of forskolin and DHEAS stimulation. The proteins were separated through 1-D and 2-D electrophoresis gels. The individual spots or bands were digested with trypsin and resultant peptides were extracted out from gel slices. The peptides were analysed by MALDI-TOF for their accurate masses. The peptide masses obtained were searched at "Mascot" web based protein search engine for possible matches in protein databases.

\subsubsection{1-D electrophoresis of TCM}

Two members of cytochrome P450 enzymes family were identified from onedimensional SDS-PAGE of TCM fraction of $\mathrm{NCl}-\mathrm{H} 295 \mathrm{R}$ by peptide mass fingerprinting (PMF). The PMF of a band in the range of $60 \mathrm{kDa}$ resulted in identification of cholesterol monooxygenase (side chain cleaving) CYP11A1 (60142 $\mathrm{kDa})$ and $\mathrm{H}^{+}$-transporting ATPase $(56525 \mathrm{kDa})$, both with significance score. The CYP11A1 is a mitochondrial cholesterol side chain cleaving enzyme with 15 matched peptides and $27 \%$ sequence coverage (Table 4.3 ), while $\mathrm{H}^{+}$-transporting ATPase, with 17 peptides matched and sequence coverage of $42 \%$ (Table 4.4 ).

The PMF of another band of around $42 \mathrm{kDa}$ resulted in identification of CYP21A1, another member of the cytochrome P450 family. The CYP21A1 catalyses the 21hydroxylation of corticosteroids. The sequence coverage for CYP21A1 was $16 \%$ and mass of $42315 \mathrm{kDa}$, which was corresponding to the band location on 1DE gel. The TCM factions separated on 1-DE is shown in the figure 4.46 with of the MALDI-TOF generated spectrum of CYP11A1 and $\mathrm{H}+$-transporting ATPase peptides. The matching peptide from CYP11A1 and $\mathrm{H}+$-transporting ATPase by peptide mass fingerprinting of 1DE band are listed in table 4.3 and 4.4 


\begin{tabular}{llll}
\hline MH $^{\mathbf{+}}$ & Start & End & Peptide sequence \\
\hline 767.40 & 85 & 90 & YGPIYR \\
812.42 & 446 & 451 & NITYFR \\
884.40 & 113 & 120 & SEGPNPER \\
971.52 & 177 & 184 & DFVSVLHR \\
1004.52 & 452 & 460 & NLGFGWGVR \\
1055.54 & 444 & 451 & DKNITYFR \\
1103.63 & 397 & 405 & YLVNDLVLR \\
1162.68 & 387 & 396 & LHPISVTLQR \\
1243.69 & 166 & 176 & NFLPLLDAVSR \\
1385.73 & 74 & 84 & VHLHHVQNFQK \\
1386.69 & 265 & 276 & DHVAAWDVIFSK \\
1628.82 & 205 & 218 & FAFESITNVIFGER \\
1717.81 & 277 & 289 & ADIYTQNFYWELR \\
1857.82 & 425 & 439 & EPTFFFDPENFDTR \\
1922.03 & 397 & 412 & YLVNDLVLRDYMIPAK
\end{tabular}

Table 4.3 The CYP11A1 matching peptide. The table shows sequences of matching peptides for CYP11A1 by web based "Mascot" search results along their calculated masses and positions in the protein.

\begin{tabular}{llll}
\hline $\mathbf{M H}^{+}$ & Start & End & Peptide sequence \\
\hline 974.63 & 202 & 212 & IGLFGGAGVGK \\
1037.67 & 134 & 143 & IPVGPETLGR \\
1087.66 & 189 & 198 & VVDLLAPYAK \\
1277.69 & 110 & 121 & TIAMDGTEGLVR \\
1400.76 & 144 & 155 & IMNVIGEPIDER \\
1405.74 & 226 & 239 & AHGGYSVFAGVGER \\
1434.82 & 311 & 324 & FTQAGSEVSALLGR \\
1438.85 & 282 & 294 & VALTGLTVAEYFR \\
1600.85 & 265 & 279 & VALVYGQMNEPPGAR \\
1616.85 & 265 & 279 & VALVYGQMNEPPGAR \\
1649.95 & 95 & 109 & LVLEVAQHLGESTVR \\
1830.86 & 407 & 422 & IMDPNIVGSEHYDVAR \\
1918.11 & 125 & 143 & VLDSGAPIKIPVGPETLGR \\
1987.05 & 388 & 406 & AIAELGIYPAVDPLDSTSR \\
2038.02 & 463 & 480 & FLSQPFQVAEVFTGHMGK \\
2075.92 & 242 & 259 & EGNDLYHEMIESGVINLK \\
2297.07 & 325 & 345 & IPSAVGYQPTLATDMGTMQER
\end{tabular}

Table 4.4 The $\mathrm{H}^{+}$-transporting ATPase matching peptide. The table shows sequences of matching peptides for $\mathrm{H}^{+}$-transporting ATPase by web based "Mascot" search results along their calculated masses and positions in the protein. 


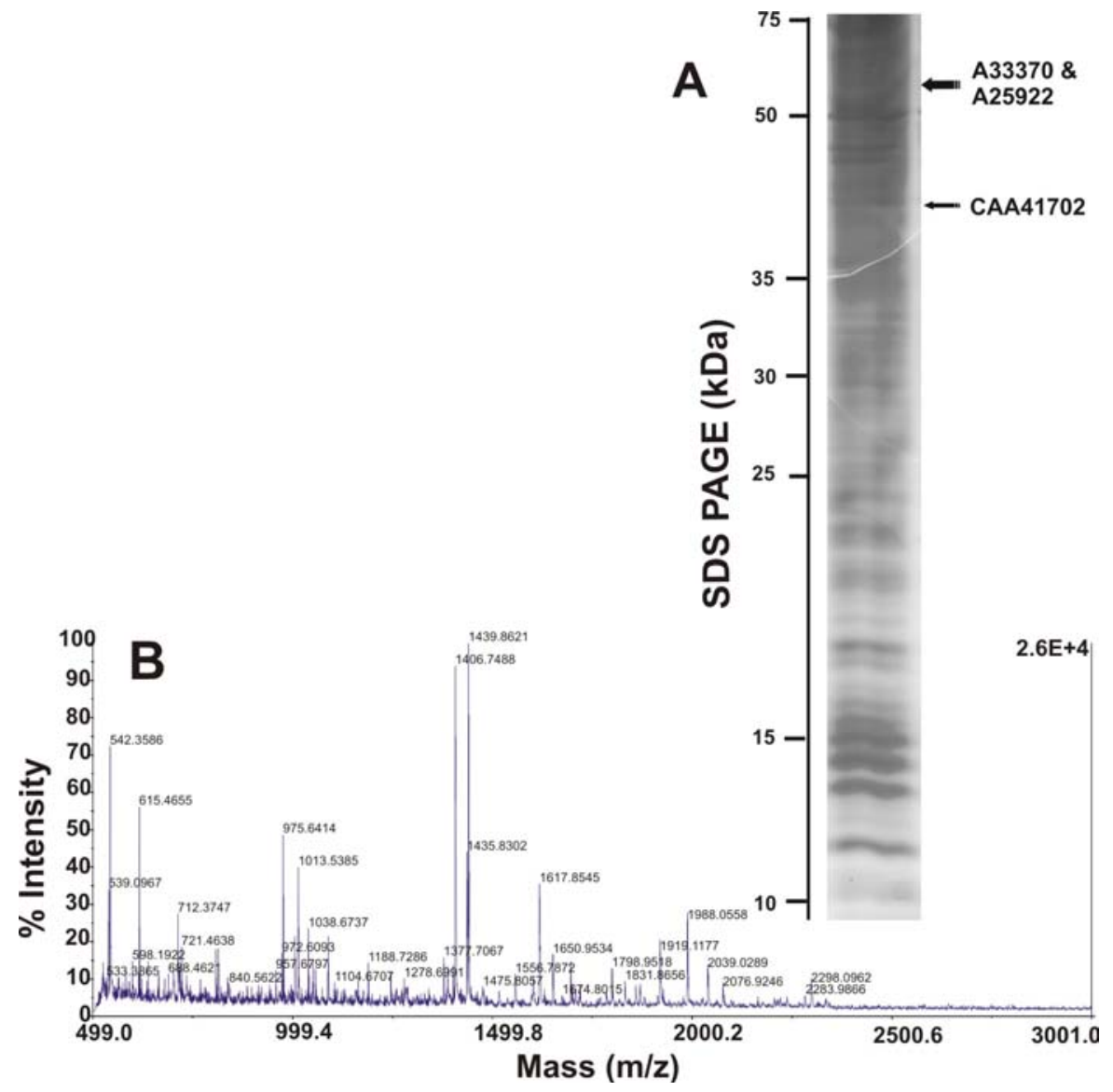

Figure 4.46 1-D electrophoresis of TCM fraction and MALDI-TOF generated spectrum from model 1DE band containing CYP11A1/H+-transporting ATPase. (A) The TCM fraction was separated by 1DE. The bands containing protein of interest are indicated by arrow. (B) MALDI-TOF generated spectrum from peptides of one band from 1-DE separated TCM. After separating the TCM by 1DE, the gel band was excised and digested with trypsin. Peptides obtained from the digestion were analysed by MALDI-TOF MS. The proteins represent the mass/charge ratio of ions detected in the MALDI-TOF experiment. The ordinate represents the relative averaged intensity of the peptide abundance in the mixture.

\subsubsection{2-D electrophoresis of TCM}

The membrane enriched fractions from control, forskolin, or DHEAS treated $\mathrm{NCl}$ H295R cells were separated by 2-DE and gels were stained with Coomassie Brilliant Blue (BBB) or silver staining. The individual spots were excised from one representative gel and digested with trypsin. The obtained peptides were analysed on MALDI-TOF and corresponding protein identity was revealed through PMF. The results showed a reproducible separation of membrane proteins by 2-DE. The figure 4.47 shows a BBB stained gel with location of the spots identified so far. Almost 140 proteins have been identified from one gel containing membrane fraction of not 
treated control $\mathrm{NCl}-\mathrm{H} 295 \mathrm{R}$ cells. Among them are plasma, endoplasmic reticulum and mitochondrial membrane proteins and membrane binding proteins. No member of cytochrome P450 enzyme has been identified, through 2-DE. The identity of the matching protein, with molecular masses and score are listed in the appendix 1 , under the same spot numbers appeared on the gel.

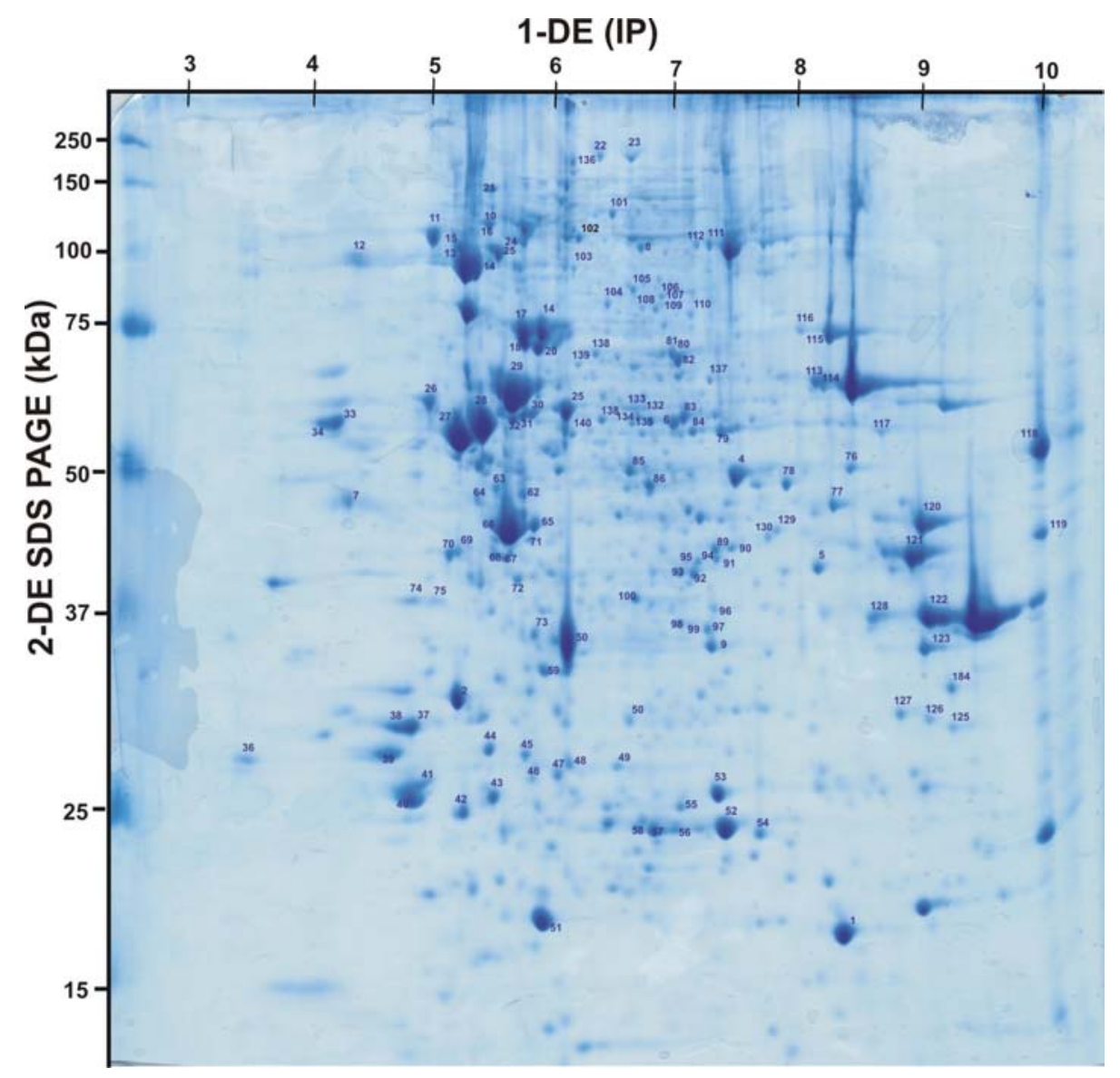

Figure 4.47 Coomassie Brilliant Blue stained 2-DE gel from TCM fraction of nonstimulated control $\mathrm{NCl}-\mathrm{H} 295 \mathrm{R}$ cells. The TCM fraction was separated by 2-DE and individual spots were excised out. After in-gel digestion, the spots were analysed at MALDITOF. The "numbers" on gel, represents the location of the relevant spot. The protein identity of spots is listed in the appendix 1 under the same numbering appeared on gel. 


\section{DISCUSSION}

\subsection{RELEASE OF STEROID HORMONES FROM HUMAN ADRENOCORTICAL CELLS}

There seem to be no cells that lack glucocorticoid receptors and as a consequence, the steroid hormones have a huge number of effects on physiologic systems. Glucocorticoids are commonly believed to readily diffuse across plasma membranes by virtue of their highly lipophilic nature and their small size. However, in vitro studies demonstrated retention of steroids against a concentration gradient at the plasma membrane (Inaba et al. 1974; Whitehouse et al. 1971). Several reports have appeared from time to time about an interaction of steroids with carrier proteins in cell membranes (Chen et al. 1996; Rao et al. 1976; Thompson 1995; Ullrich et al. 1991). Uptake experiments in perfused proximal tubules of the rat kidneys indicated the interaction of steroid hormones with the $p$-aminohippurate transporter (Ullrich et al. 1991). Recent studies in our group demonstrated the involvement of organic anion transporter 1 in the cortisol release from bovine adrenal cells, and immunohistochemical localization revealed a high expression of OAT1 in the zona fasciculata of rat adrenal tissue (Beery et al. 2003). Based on these findings, it was important to address the question of participation of transporter protein in steroid release process also in human adrenal cells.

\subsubsection{The human adrenocortical cell line}

A number of in vitro systems have been used to study human adrenal function, including tissue slices, cell suspension from dispersed tissue, and primary and secondary monolayer cultures from the normal adrenal. The biggest hindrances to work in human models are the availability of the tissue samples and ethical concerns. The second problem is the great variation in the pathology, steroid release profile and treatment history of the donor. All these factors contribute to variations in the results. Although a long-term culture of non-tumor adrenocortical cells is possible, cells cultured in this manner loose many of the differentiated functions (Rainey et al. 1994).

The advantage of an adrenocortical cell line is the availability to undertake experiments requiring a large number of cells. The biggest challenge in the cell line research is the selection of a truly representative cell line for the research objectives. The availability of a cell line, which expresses the complement of adrenal 
steroidogenic enzymes, would clearly be helpful in the determination of the mechanism leading to the production of different steroid hormones by each of the three zones of the adrenal cortex and in defining a model system for the release of steroids from adrenocortical cells.

The human adrenocortical cell line $\mathrm{NCl}-\mathrm{H} 295 \mathrm{R}$, expressing the full complement of human adrenocortical enzymes could provide answers to these questions. $\mathrm{NCl}$ H295R cells originally cultured from a human adrenocortical tumor in 1980, continued to express the three major pathways of adrenal steroidogenesis. The possibility to direct $\mathrm{NCl}-\mathrm{H} 295 \mathrm{R}$ cells into cells producing mineralcorticoids, glucocorticoids or C19steroids provides a valuable model for elucidating the role of transporter proteins in steroid release from adrenocortical cells. Under the forskolin stimulation $\mathrm{NCl}-\mathrm{H} 295 \mathrm{R}$ cell represents zona fasciculata cells and produce cortisol as almost $70 \%$ of total steroid product (Rainey et al. 1993; Rainey et al. 1994), making it a suitable model to undertake the present study.

The cortisol produced by $\mathrm{NCl}-\mathrm{H} 295 \mathrm{R}$ cells was measured through radioimmunoassay (RIA). The antibody used showed $100 \%$ cross reactivity with cortisol and corticosterone and no cross reactivity against aldosterone, testosterone, estradiol, androstendione, progesterone, estrone sulfate and DHEAS. The culture media was always used to generate the standard curve to avoid any false cortisol measurement. The sensitivity of the standard curve ranged from $3 \mathrm{pg} / 10 \mu$ lo 3000 $\mathrm{pg} / 10 \mu \mathrm{l}$, and a total sample volume of $10 \mu \mathrm{l}$. The cortisol assay is quite sensitive and provides a sufficient basis to undertake the study.

\subsubsection{Cortisol release from $\mathrm{NCl}-\mathrm{H} 295 \mathrm{R}$ cells}

The NCl-H295R cells produce less cortisol under the un-stimulated condition. After 6 $\mathrm{h}$ the cortisol could be measured in the culture media in non-stimulated conditions. The effect of forskolin stimulation was observed at least after 3-6 h of stimulation (Rainey et al. 1994). We could measure the cortisol release after 6 hours and a detectable effect of forskolin was also apparent after 6 hours of stimulation. In order to obtain clear results for comparative experiments, a $24 \mathrm{~h}$ treatment period was used.

ACTH induced a threefold greater cortisol release after 48 hours of treatment. The $\mathrm{NCl}-\mathrm{H} 295 \mathrm{R}$ cells showed less response to the ACTH stimulation as compared to invivo, where ACTH is the major stimulus of cortisol secretion. The smaller effects of ACTH were probably due to decreased expression of ACTH receptor in these cells (Mountjoy et al. 1994). Like ACTH stimulates protein kinase A pathway (Dempsher et al. 1984), to mimic the same effects we used forskolin. 
Forskolin, a naturally occurring diterpene isolated from the Indian herb Coleus forskohlii, is an agonist of the protein kinase A (PKA) pathway. Forskolin directly stimulates adenylyl cyclase and has been used extensively to increase cAMP. Treatment of $\mathrm{NCl}-\mathrm{H} 295 \mathrm{R}$ cells with forskolin showed significantly increased cortisol release. Six hours treatment with forskolin increased the cortisol by 3 fold. The cortisol release was 25 fold greater after 24 hours stimulation with forskolin as compared to non-stimulated control cells. These results are in good agreement with previous data reported for these cells (Rainey et al. 1993). After 24 hours forskolin treatment, cortisol became the major steroid product, representing $70 \%$ of the total steroid products (Rainey et al. 1994). The cortisol synthesis remained higher for 24 hours, even after replacing the forskolin containing medium with control medium. This is probably due to the fact that forskolin treatment increased the expression of key enzymes of steroid biosynthesis (Bird et al. 1998b). Forskolin stimulation increased the production of cortisol and made the cells a representative model of zona fasciculata cells. Therefore, in the present study, the cells were pre-treated for 24 hours with forskolin to turn them into more zona fasciculata like cells.

\subsubsection{Inhibition of cortisol release from NCl-H295R cells}

After verification of the human cell model for cortisol release, we checked, whether human organic anion transporters are involved in the secretion of cortisol. Recently it has been shown in bovine adrenal cells that basic and ACTH stimulated cortisol release was reduced by probenecid and trans-stimulated by $\mathrm{PAH}$, and a renal organic anion/dicarboxylate exchanger was proposed for involvement in cortisol release (Steffgen et al. 1996).

In order to study the influence of potent inhibitors and substrates of OATs on cortisol release, probenecid was used initially. Probenecid is considered as a broad range, unspecific inhibitor of organic anion transporters. It is also known as substrate of the renal organic anion secretory system (Sheikh et al. 1977; Sheikh et al. 1979). We observed an inhibition by 0.5 and $1 \mathrm{mM}$ probenecid. Many unspecific effects of probenecid have been reported, including altered $\mathrm{Ca}^{2+}$-homeostasis and reduction in the tissue oxygen consumption. Probenecid uncouples mitochondrial oxidative phosphorylation, reduces cellular ATP levels, and depolarizes the plasma membrane (Masereeuw et al. 2000). So it cannot be excluded that part of inhibitory effect of probenecid on cortisol release might be due to inhibition of cortisol synthesis. However, intracellular cortisol rose in cells incubated with probenecid, indicating that there is no prominent inhibitory effect of probenecid on cortisol synthesis (Steffgen et al. 1996). 
In the next step, we tried to inhibit the cortisol release by the model substrate of OATs, PAH. PAH is more specific and selective for OATs. It has a high affinity to OAT1, and a low one to OAT3. PAH has also been reported as substrate of MRP2 (van Aubel et al. 2000). Cortisol release was markedly reduced only in presence of a high PAH concentration (5 mM). Glutarate, another specific substrate of OAT1 and OAT3, showed an inhibition of $31 \%$ at $0.25 \mathrm{mM}$ concentration.

As OAT1 and OAT3 are known to be working in an exchanger mode (Bakhiya et al. 2003; Burckhardt et al. 2002b), PAH and glutarate should increase cortisol release from the $\mathrm{NCl}-\mathrm{H} 295 \mathrm{R}$ cells rather than inhibit it. The observed inhibition might be due to the long time incubation of the $\mathrm{NCl}-\mathrm{H} 295 \mathrm{R}$ with these substances. During 24 hours, PAH or glutarate enter the cells, i. e. PAH or glutarate are present on both sides of the cell membrane. The cytosolic PAH or glutarate may then partly displace intracellular cortisol from a putative common organic anion transporter. The relatively high $\mathrm{PAH}$ concentrations required for inhibition in our experiments may be due to a limited intracellular accumulation of PAH and/or to a low affinity of the internal anion binding site of organic anion transporters for $\mathrm{PAH}$.

Cimetidine is a cationic drug widely used in the characterization of organic cation transporters. So far it has been reported to be effectively transported by two members of OAT family, OAT1 and OAT3, (Burckhardt et al. 2001a; Burckhardt et al. 2002a; Cha et al. 2001). We observed a $44 \%$ inhibition of cortisol release by incubating cells with $0.5 \mathrm{mM}$ cimetidine. In conclusion, various substrates of OATs affected cortisol release from human adrenocortical cells. The effects of probenecid, $\mathrm{PAH}$, glutarate and cimetidine were significant, are in accordance with earlier findings on bovine adrenal cells (Steffgen et al. 1996), and suggest that an OAT might be involved in cortisol release also from human adrenocortical cells.

\subsection{PAH UPTAKE IN NCI-H295R CELLS}

The uptake of radiolabeled PAH into bovine adrenal cells was stimulated by preloading with $\mathrm{PAH}$ and by ACTH treatment (Steffgen et al. 1999). We performed uptake of radiolabeled $\mathrm{PAH}$ in $\mathrm{NCl}-\mathrm{H} 295 \mathrm{R}$ cells to clarify, whether the same mechanism is occurring in the human adrenal. A time dependent PAH uptake was observed in $\mathrm{NCl}-\mathrm{H} 295 \mathrm{R}$ cells. The $\mathrm{PAH}$ uptake was temperature sensitive and there was only negligible background radioactivity when experiments were conducted on $4^{\circ} \mathrm{C}$, indicating that this uptake is temperature sensitive as expected from a proteinmediated transport (Zhou et al. 2003). 
PAH uptake in forskolin stimulated cells was compared with non-stimulated cells. OAT mediated PAH uptake was increased by only $28 \%$ over non-treated cells, indicating that forskolin showed only minor effects on PAH transport, whereas the cortisol release was stimulated more than thirtyfold. At a first sight the differences between the forskolin stimulated cortisol release and PAH uptake is obvious. This discrepancy could be due to a difference of the experimental conditions: cortisol release experiments were conducted over 24 hours, while the PAH uptake was measured in $15 \mathrm{~min}$. In addition, it might be that in non-stimulated cells the transporter was operating far below its full capacity. Upregulation of cortisol synthesis then does not necessarily require the same degree of upregulation of transporters. The $28 \%$ increase of $\mathrm{PAH}$ uptake in $\mathrm{NCl}-\mathrm{H} 295 \mathrm{R}$ cells after forskolin treatment was probably induced by PKA pathway. Recent studies in opossum kidney (OK) cells showed an increased uptake of organic anions through OATs, which was induced by PKA activation (Sauvant et al. 2003).

The uptake of radiolabeled $\mathrm{PAH}$ into $\mathrm{NCl}-\mathrm{H} 295 \mathrm{R}$ cells was almost insensitive to probenecid and unlabeled PAH. Probenecid inhibited uptake by $13.5 \%$ and $54.4 \%$ at $1 \mathrm{mM}$ and $5 \mathrm{mM}$, respectively, and unlabeled $\mathrm{PAH}$ decreased radiolabeled $\mathrm{PAH}$ uptake poorly. As OAT1 has a high affinity for PAH, these results casted doubts on the involvement of OAT1 in PAH uptake in human adrenocortical cells (Bahn et al. 2002b; Hagos et al. 2002; Sekine et al. 1998a; Sweet et al. 1997).

The PAH uptake was significantly inhibited even in the presence of low doses of estrone sulfate. $10 \mu \mathrm{M}$ estrone sulfate inhibited the PAH uptake to $36 \%$ in $\mathrm{NCl}$ H295R cells. The OAT1 has very low affinity for estrone sulfate while the affinity for $\mathrm{PAH}$ and probenecid is a hallmark of hOAT1. On the other hand, estrone sulfate is known to be a high-affinity substrate of OAT3, which in turn has a low affinity for PAH and probenecid. The increased inhibition of PAH uptake by estrone sulfate strongly argued in favour of a transporter, which has a higher affinity for estrone sulfate than for PAH. These results fit more to hOAT3 than to hOAT1 in NCI-H295R cells.

In order to clarify whether the PAH transporter in $\mathrm{NCl}-\mathrm{H} 295 \mathrm{R}$ cells is working as an exchanger, we preloaded the cells with unlabeled $\mathrm{PAH}$, glutarate or cortisol, and performed uptake of labeled $\mathrm{PAH}$. We found a significant stimulation of PAH uptake into $\mathrm{NCl}-\mathrm{H} 295 \mathrm{R}$ cells by all preloadings.

The observed stimulation is called trans-stimulation, i.e. a substrate at the inside of the cell membrane (= trans side) stimulates the uptake of another substrate present at the outside. Trans-stimulation is generally considered as a proof for translocation by a common carrier. Without substrate at the inside, a carrier has to return unloaded to the external side to pick up the next substrate molecule for uptake. The turnover of 
an empty (unloaded) carrier is in most cases relatively slow. If a substrate is present at the inside, the transport cycle does no longer include the relatively slow step, which results in the trans-stimulation.

In our case, $\mathrm{PAH}$ uptake was trans-stimulated by $\mathrm{PAH}$, glutarate, and cortisol i.e. the transporter is able to operate in the modes $\mathrm{PAH} / \mathrm{PAH}$ exchange, $\mathrm{PAH} / \mathrm{glutarate}$ exchange, and $\mathrm{PAH} /$ cortisol exchange. In the latter case, $\mathrm{PAH}$ is taken up and cortisol is released by the same transporter, most probably an exchanger such as OAT1 or OAT3.

In the next phase, glutarate was tested for the ability to inhibit PAH uptake in preloaded adrenocortical cells. Significant inhibition was observed with $0.5 \mathrm{mM}$ glutarate in case of PAH and glutarate preloaded cells. Inhibition of cortisol was also tested in order to ascertain, whether cortisol can interact with the PAH transport system also from the outside, and to verify the cortisol release inhibition induced by $\mathrm{PAH}$ in bovine adrenal cells (Steffgen et al. 1996; Steffgen et al. 1999). The presence of $50 \mu \mathrm{M}$ cortisol in the transport medium, significantly reduced the transstimulated PAH uptake. Taking these finding together suggests that the transporter involved in the human adrenocortical cells is working as an organic anion/dicarboxylate exchanger, has low affinity for $\mathrm{PAH}$ and probenecid, and high for estrone sulfate. The present results in combination with trans-stimulation fits well with the expected model of a cortisol releasing transporter in exchange of any organic anion or dicarboxylate.

\subsection{CORTISOL TRANSPORT BY OATS}

In order to clarify, which member of OAT family could potentially mediate cortisol release in human, we undertook functional studies with OAT1-4 to answer this question. Three experimental approaches were used. 1) To verify the presence of mRNA for transporters, RT-PCR of NCl-H295R cells and human normal and tumor tissues was carried out. 2) HEK-293 cells stably transfected with different transporters were used to study the affinity for cortisol. 3) Transporter protein expressing Xenopus laevis oocytes were used to study the direct uptake of radiolabeled cortisol by the respective member of the OAT family.

\subsubsection{Organic anion transporter 1 (OAT1)}

The rat and bovine OAT1 has been postulated to be responsible for cortisol release from adrenal glands. The rOAT1 was detected in rat adrenal by PCR and in situ 
hybridisation experiments, showing that ACTH increased the labelling for rOAT1 in the zona fasciculata (Beery et al. 2003; Steffgen et al. 1999). We used the RT-PCR approach in order to check the existence of OAT1 in human adrenal glands. Unexpectedly, PCR experiments on $\mathrm{NCl}-\mathrm{H} 295 \mathrm{R}$ cells and human normal and tumor adrenal tissue from the same donor did not reveal the expression of hOAT1. The PCR reaction with the plasmid of human OAT1 yielded signals of expected molecular size. The primer specificity and quality of PCR reaction was also confirmed by signals of expected size when PCR was conducted using cDNA prepared from human kidney tissue and human kidney cDNA library. These results are in contrast to what has been reported in rat and bovine adrenals, where OAT1 was postulated as the major mediator of cortisol release. This might be due the species differences between rat and human.

In the next step we evaluated the ability of hOAT1 to interact with cortisol. For this purpose, the inhibitory action of unlabeled cortisol was documented against radiolabeled PAH uptake in HEK-293 cells stably transfected with hOAT1. The results demonstrated a 30 fold higher $\mathrm{PAH}$ uptake in hOAT1 transfected cells over non-transfected control cells. The major part of radiolabeled PAH uptake was abolished by use of $100 \mu \mathrm{M}$ probenecid, which is a prominent characteristic of hOAT1 (Burckhardt et al. 2003). The inhibition with cortisol was, however, not very pronounced, and only one fifth of uptake was inhibited with $50 \mu \mathrm{M}$ cortisol in the transport media. This showed a low interaction of cortisol with hOAT1.

In order to demonstrate the ability of hOAT1 to directly translocate cortisol, we injected the hOAT1 in Xenopus laevis oocytes. OAT1 expressing oocytes showed an almost 27 fold greater PAH uptake over water injected oocytes, confirming that OAT1 is functionally expressed in the oocytes. There was no significant cortisol uptake in hOAT1 expressing oocytes in comparison to water injected oocytes. This shows that hOAT1 does not transport cortisol. However, we do not know whether rat and bovine OAT1 could transport corticosterone and cortisol. Taking together all these results about interaction of hOAT1 with cortisol along with the PAH uptake findings in the $\mathrm{NCl}-\mathrm{H} 295 \mathrm{R}$ cells, a different picture emerges than what has been learned in rat and bovine adrenal experiments. The PAH uptake in NCl-H295R cells, was hardly affected by unlabeled $\mathrm{PAH}$ and probenecid, but was sensitive to estrone sulfate, the absence of mRNA for hOAT1 in NCl-H295R cells, human normal, and tumor adrenal tissues, a low interaction of cortisol with PAH uptake in hOAT1 transfected HEK-293 cells, and, finally, no direct transport of cortisol by hOAT1 expressing Xenopus laevis oocytes confirm that in human adrenocortical cells, hOAT1 is not playing the significant role. 


\subsubsection{Organic anion transporter 2 (OAT2)}

Human OAT2 has been cloned from liver and its message was also more abundant in liver than in kidneys (Sun et al. 2001). We checked its expression in the human adrenal cells and tissues. The RT-PCR studies for expression of human OAT2 did not result in any product from $\mathrm{NCl}-\mathrm{H} 295 \mathrm{R}$ cells, human normal and tumor tissues. However, PCR with the hOAT2 containing plasmid resulted in a product of expected size. The PCR reaction validity and specificity of the primer was confirmed as we obtained the same sized product from the human kidney cDNA. The results confirmed that OAT2 does not exist in the human adrenals.

The hOAT2 expressing Xenopus laevis oocytes were used to clarify the ability of this transporter for direct cortisol translocation. The hOAT2 injected oocytes did not transport cortisol, but also there was no significant transport by hOAT2 expressing oocytes when incubated with transport medium containing radiolabeled salicylic acid. Since salicylic acid is know to be effectively transported by hOAT2 (Burckhardt et al. 2003), we conclude that the available hOAT2 clone was not functional and we can therefore not predict the ability of hOAT2 to transport cortisol.

\subsubsection{Organic anion transporter 4 (OAT4)}

Human OAT4 has been cloned from kidney and its mRNA is also present in placenta (Cha et al. 2000). The RT-PCR with hOAT4 specific primers yielded signals of the expected size from adrenocortical cells as well as from human normal and tumor tissues. The product specificity was confirmed by sequencing. The PCR with hOAT4 plasmid also resulted in the same size product. We do not yet know about hOAT4 expression in rat and bovine adrenals, as to our knowledge nobody tested their expression in adrenals for these species. Thus, it is premature to conclude that OAT4 is present only in human adrenals.

In order to demonstrate their interaction with cortisol, we used HEK-293 cells stable transfected with hOAT4. The hOAT4 transfected cells showed an uptake of radiolabeled DHEAS, 17 fold greater than non-transfected control cells. This uptake was significantly inhibited by unlabeled estrone sulfate. This data is in agreement with earlier findings where DHEAS and estrone sulfate have been reported as important substrates of hOAT4 (Cha et al. 2000). The presence of unlabeled cortisol in the transport medium also inhibited uptake of radiolabeled DHEAS, but to a lesser extent, showing a poor affinity to the transporter. 
To evaluate the ability of hOAT4 for direct transport of radiolabeled cortisol, we expressed hOAT4 in Xenopus laevis oocytes. The hOAT4 expressing oocytes showed a significant uptake of radiolabeled DHEAS over water injected oocytes. But there was no significant uptake of radiolabeled cortisol in hOAT4 expressing oocytes. That the hOAT4 expressing oocytes showed DHEAS uptake, but not cortisol uptake, emphasizes that transporter was functionally expressed but could not translocate cortisol. However, estrone sulfate, DHEAS and many steroid conjugates are substrates of hOAT4 (Cha et al. 2000). It remains to be clarified which role hOAT4 might be playing in adrenal cells.

\subsubsection{Organic anion transporter 3 (OAT3)}

The human OAT3 was first cloned by Race (Race et al. 1999), but could not be functionally expressed. Later on, a functional clone was isolated from a human kidney library (Cha et al. 2001). The hOAT3 expression was found in the NCl-H295R cells, human normal and tumor tissues, which was of the expected size and corresponded with the product resulting from PCR of the hOAT3 plasmid. The expression of OAT3 has not been reported in adrenal of any other species up today. Real-time PCR data reported by Motohashi demonstrated a species difference in expression level of OAT1 and OAT3 in rat and human. He reported that human kidney cortex have twofold higher expression of hOAT3 compared to hOAT1, and a more than tenfold higher expression than that of hOAT2 and hOAT4 (Motohashi et al. 2002). While previous reports on gender differences in mRNA expression of OATs showed highest expression of rOAT1 than rOAT3 in male adult rats (Buist et al. 2002).

The hOAT3 transfected HEK-293 cells showed a 20 fold higher radiolabeled estrone sulfate uptake than non-transfected control cells. The estrone sulfate uptake was completely inhibited by presence of $100 \mu \mathrm{M}$ unlabeled estrone sulfate, which was expected because estrone sulfate is known to be a good substrate of hOAT3 (Bakhiya et al. 2003; Cha et al. 2001). The presence of $50 \mu \mathrm{M}$ cortisol in the transport medium showed a highly significant $(70 \%)$ inhibition. The calculated $\mathrm{IC}_{50}$ value for cortisol in hOAT3 transfected HEK-293 cells was $21.0 \mu \mathrm{M}$.

The OAT3 expressing Xenopus laevis oocytes showed a high estrone sulfate uptake as compared to water-injected oocytes, confirming the functional expression of transporter in the oocytes. The interesting results were observed when hOAT3 expressing oocytes were checked for their ability to translocate radiolabeled cortisol. hOAT3 expressing oocytes showed a fourfold greater radiolabeled uptake than water injected control oocytes. This is the first evidence of a direct uptake of radiolabeled 
cortisol by any organic anion transporter. So far only Bossuyt and co workers have shown an uptake of cortisol in rat Oatp1 expressing Xenopus laevis oocytes (Bossuyt et al. 1996a).

The expression of mRNA for hOAT3 in the NCl-H295R, human normal and tumor tissues, inhibition of estrone sulfate uptake in hOAT3 transfected HEK-293 cells by cortisol, and ability of hOAT3 expressing oocytes to transport cortisol was an important finding. Therefore, we investigated the affinity of hOAT3 for cortisol. For this purpose OAT3 expressing Xenopus laevis oocytes were used The uptake of cortisol was saturable and the calculated $\mathrm{K}_{\mathrm{t}}$ value of cortisol was $2.4 \mu \mathrm{M}$ in OAT3 expressing Xenopus laevis oocytes. When radiolabeled estrone sulfate uptake and its inhibition with unlabeled cortisol was carried out in OAT3 expressing Xenopus laevis oocytes, the calculated $\mathrm{IC}_{50}$ value obtained for cortisol was $15.6 \mu \mathrm{M}$. This $\mathrm{IC}_{50}$ is higher than the $\mathrm{K}_{\mathrm{t}}(2.4 \mu \mathrm{M})$ value. This difference may be due to the high affinity of hOAT3 for estrone sulfate. The reported $K_{m}$ value for labeled estrone sulfate uptake and inhibition by unlabeled estrone sulfate in the hOAT3 expressing Xenopus laevis oocytes is $3.1 \mu \mathrm{M}$ (Cha et al. 2001). Therefore, the $I C_{50}$ is higher than the $K_{t}$, because unlabeled cortisol competed with estrone sulfate for OAT3.

Taking together, the expression of hOAT3 in the adrenal tissues and $\mathrm{NCl}-\mathrm{H} 295 \mathrm{R}$ cells, a saturable radiolabeled cortisol uptake in hOAT3 expressing oocytes, and inhibition of estrone sulfate uptake in hOAT3 expressing oocytes by cortisol point out a significant role of hOAT3 in cortisol producing cells.

\subsection{ESTRONE SULFATE UPTAKE IN NCI-H295R CELLS}

After observing the expression of hOAT3 mRNA in NCl-H295R cells and human tissues and its ability to transport cortisol in the OAT3 expressing Xenopus laevis oocytes, we checked the uptake of a favourite substrate of hOAT3, estrone sulfate, into $\mathrm{NCl}-\mathrm{H} 295 \mathrm{R}$ cells. We found a time dependent estrone sulfate uptake, which was increased $22 \%$ by forskolin stimulation. The increased uptake of estrone sulfate by forskolin treatment has also been observed in rat placental cell line HRP-1, where forskolin and 8-bromo-cAMP stimulated the apical transport activity. However, the protein regulation and exact identity of the carrier was not revealed (Zhou et al. 2003). The estrone sulfate uptake in $\mathrm{NCl}-\mathrm{H} 295 \mathrm{R}$ cells was saturable and the calculated $\mathrm{K}_{\mathrm{i}}$ value was $9.82 \mu \mathrm{M}$. This value fits well with the $\mathrm{K}_{\mathrm{i}}$ of rat OAT3expressing LLC-PK1 cells $\left(\mathrm{K}_{\mathrm{i}}=9.1 \mu \mathrm{M}\right)$ (Nagata et al. 2002), and human OAT3 expressing Xenopus laevis oocytes $\left(\mathrm{K}_{\mathrm{i}}=3.1 \mu \mathrm{M}\right)($ Cha et al. 2001). DHEAS inhibited estrone sulfate uptake in $\mathrm{NCl}-\mathrm{H} 295 \mathrm{R}$ cells with an $\mathrm{IC}_{50}$ of $10.6 \mu \mathrm{M}$, which 
corresponds to the high affinity of hOAT3 for DHEAS as reported earlier (Cha et al. 2001).

The presence of unlabeled cortisol in the uptake medium significantly reduced estrone sulfate uptake in $\mathrm{NCl}-\mathrm{H} 295 \mathrm{R}$ cells. The calculated $\mathrm{IC}_{50}$ value of cortisol inhibition to estrone sulfate uptake was $38.9 \mu \mathrm{M}$. This value is quite high with respect to the $\mathrm{K}_{\mathrm{t}}$ value $(2.4 \mu \mathrm{M})$ of cortisol uptake and the $\mathrm{IC}_{50}$ of $15.6 \mu \mathrm{M}$ of cortisol inhibition of estrone sulfate uptake in hOAT3 expressing oocytes. The reason for this discrepancy between cells and oocytes is not completely clear. Possibly, cortisol does not reach easily the transport sites in cells grown on impermeant plastic dish and/or is bound to cell surface, thereby reducing the concentration of free cortisol. In these cases the concentration of cortisol at the transport may be blew than that in the bulk fluid, leading to innocuously high $\mathrm{IC}_{50}$ values.

As characteristic features of an exchanger, trans-stimulation and cis-inhibition were tested with the representative substances of the likely transporter. Estrone sulfate uptake was cis-inhibited with $100 \mu \mathrm{M}$ and $1 \mathrm{mM}$ probenecid. Both concentrations resulted in a significant reduction in estrone sulfate uptake in $\mathrm{NCl}-\mathrm{H} 295 \mathrm{R}$ cells. But as discussed in the PAH uptake section, probenecid is an unspecific inhibitor and it is difficult to draw a specific conclusion. Therefore, we checked the cis-inhibition by cimetidine. Cimetidine is a potent substrate of hOAT3. With $10 \mu \mathrm{M}$ cimetidine we found a highly significant inhibition of radiolabeled estrone sulfate uptake, clearly indicating the functional expression of hOAT3 in NCl-H295R cells. A higher concentration of cimetidine $(1 \mathrm{mM})$ did not increase the inhibitory effect, demonstrating saturation. A significant inhibition was also observed with $10 \mu \mathrm{M}$ glutarate. Higher concentrations just added a little to the inhibitory effect, showing an almost complete saturation with the low concentration. Taurocholate is a substrate of OATPs and has been used extensively to characterize the members of this OATP family (Abe et al. 1999; Briz et al. 2003; Kullak-Ublick et al. 2001). Its interaction with hOAT3 has also been reported (Cha et al. 2001). We checked the influence of taurocholate on estrone sulfate uptake in NCl-H295R cells. Smaller concentrations of taurocholate did not produce any significant effect. At $1 \mathrm{mM}$, taurocholate inhibited radiolabeled estrone sulfate significantly. The estrone sulfate uptake and its inhibitory profile clearly indicate the functional presence of hOAT3 in the NCl-H295R cells.

As rat and human OAT3 have been shown to perform organic anion/dicarboxylate exchange (Bakhiya et al. 2003; Sweet et al. 2002), we performed trans-stimulation experiments with glutarate and cortisol preloaded cells. Estrone sulfate uptake into $\mathrm{NCl}-\mathrm{H} 295 \mathrm{R}$ cells was significantly stimulated by preloading the cells with glutarate, 
the non-metabolisable homolog of $\alpha$-ketoglutarate. This trans-stimulation provides another evidence that OAT3 is functioning in $\mathrm{NCl}-\mathrm{H} 295 \mathrm{R}$ cells. Other transporters accepting estrone sulfate, OAT4 and OATPs, do not operate as exchangers against dicarboxylates. Preloading of $\mathrm{NCl}-\mathrm{H} 295 \mathrm{R}$ cells with cortisol also stimulated the uptake of estrone sulfate. The most likely explanation for this finding is that estrone sulfate uptake was trans-stimulated by cortisol, i.e. the influx of estrone sulfate was coupled to the efflux of cortisol. This experiment, albeit indirect, suggests that OAT3 could contribute to cortisol efflux from adrenal cells, provided a suitable counter ion (estrone sulfate, DHEA sulfate and others) is present in the extracellular medium. However, it remains open how much hOAT3 is contributing to total cortisol release, and how much other transporters are involved.

\subsection{ROLE OF OATPS IN CORTISOL RELEASE FROM NCI- H295R CELLS}

Another candidate for participation in cortisol release from adrenal cells is the organic anion transporting polypeptide (OATP). This is a family of polyspecific transporters that can mediate charge-independent uptake of a wide variety of structurally unrelated amphipathic compounds. Many of the substrates of OAT3 and OAT4 including estrone sulfate and DHEAS are shared by OATPs (Hagenbuch et al. 2003; Kullak-Ublick et al. 2001; Kullak-Ublick et al. 2004). In 1996 Bossuyt and co-workers showed cortisol uptake by oatp1 expressing Xenopus oocytes $\left(\mathrm{K}_{\mathrm{m}}=13.0 \mu \mathrm{M}\right)$ (Bossuyt et al. 1996a), which is close to the $K_{m}$ value for low affinity transport components of cortisol uptake into isolated rat liver cells (Rao et al. 1976).

The PCR experiments on rat adrenal glands showed expression of oatp1, oatp2, and oatp3. In situ hybridization experiments confirmed the localization of three oatps in the rat adrenal glands (Beery et al. 2003). Based on the rat adrenal results for expression of Oatps and our observation for the inhibition of estrone sulfate uptake by taurocholate in $\mathrm{NCl}-\mathrm{H} 295 \mathrm{R}$ cells, we performed a PCR screening of $\mathrm{NCl}-\mathrm{H} 295 \mathrm{R}$ cells for mRNA expression of members of the OATP family. The RT-PCR with OATPA, OATP-B, OATP-C, and OATP-E specific primers was carried out in the CDNA of $\mathrm{NCl}-\mathrm{H} 295 \mathrm{R}$ cells, human normal, and adrenal tissues. The results showed the expression of OATP-A in the NCl-H295R cells, but not in the human normal or tumor tissues, whereas OATP-B signals were found only in human normal and tumor tissues, but not in the $\mathrm{NCl}-\mathrm{H} 295 \mathrm{R}$ cells. There was no positive signal for the mRNA 
expression of OATP-C and OATP-E in NCl-H295R cells as well as in human normal and tumor tissues. A possible interpretation of the differential expression of OATP-A and OATP-B might be an adaptation of the cell line. Since the only available adrenal tissue was from one patient, OATPs expression in human adrenals is not yet clear and requires experiments with samples from various patients.

To clarify the role of OATP-A and OATP-B in cortisol release we expressed them one by one in Xenopus laevis oocytes and radiolabeled cortisol uptake was conducted. The OATP-A expressing oocytes were checked for the uptake of estrone sulfate as a potent substrate of OATP-A. There was a 25 fold greater uptake of estrone sulfate in OATP-A expressing oocytes than in water-injected oocytes. This confirmed that OATP-A was functionally expressed in the oocytes. In case of radiolabeled cortisol uptake, there was $25 \%$ more uptake in OATP-A injected oocytes than in water injected oocytes. The slight, but significant uptake of labeled cortisol is in contrast to the previous reports, where no cortisol uptake was observed by OATP-A injected oocytes (Bossuyt et al. 1996b). It remains questionable whether the slow transport role of OATP-A contributes significantly to cortisol release in adrenal cells.

In order to evaluate the ability of OATP-B for cortisol transport we expressed it in Xenopus laevis oocytes. The OATP-B expressing Xenopus laevis oocytes did not show any transport of estrone sulfate, which is a potent substrate of OATP-B as reported previously (Kullak-Ublick et al. 2001; St Pierre et al. 2002). Since, therefore, our clone was not functional, it was not possible to clear for its ability to transport cortisol. To our knowledge nobody has ever test direct uptake of cortisol by OATP-B.

\subsection{ROLE OF MDR1 IN CORTISOL RELEASE FROM NCI- H295R CELLS}

P-glycoprotein acts as an energy-dependent efflux pump that exports anticancer agents out of the cell, lowering their intracellular concentration to sublethal levels, and is considered to be important in multidrug resistance of human tumors (Gottesman et al. 1988). Pgp transports a broad range of hydrophobic and amphipathic substrates (Sharom et al. 1999). A substantial number of studies corroborated the ability of MDR1 (multi drug resistance gene1 of Pgp) to transport dexamethasone and several other steroids. The MDR1 cDNA transfected pig kidney epithelial cell line can transport dexamethasone, cortisol and aldosterone (Farrell et 
al. 2000; Ueda et al. 1992). Studies in MDR1 expressing cells show reduced accumulation of cortisol as compared to not expressing cells (van Kalken et al. 1993). The expression studies showed high level expression in intestine, adrenal, pregnant uterus and placenta from human and other species (Chin et al. 1989; Flens et al. 1996; Goldstein et al. 1989). Pgp mediation of aldosterone and cortisol secretion was suggested by Ueda (Ueda et al. 1992), who showed that kidney cells transfected with MDR1 actively transported aldosterone and cortisol from the basolateral to the apical side. The expression of MDR1 was demonstrated in the zona glomerulosa of the adrenal gland (Thiebaut et al. 1987).

By RT-PCR experiments we observed a constitutive expression of MDR1 mRNA in $\mathrm{NCl}-\mathrm{H} 295 \mathrm{R}$ cells, human normal and tumor tissues. These results confirm the previous findings of the existence of MDR1 in NCl-H295R cells (Bello-Reuss et al. 2000).

After confirming the presence of MDR1 mRNA in NCl-H295R cells, we checked the influence of inhibitors of MDR1 on cortisol release from $\mathrm{NCl}-\mathrm{H} 295 \mathrm{R}$ cells. For this purpose, the $\mathrm{NCl}-\mathrm{H} 295 \mathrm{R}$ cells were stimulated with forskolin and incubated with different concentrations of verapamil and cyclosporine in the presence of forskolin. The results demonstrated a concentration dependent inhibition of cortisol release by MDR1 inhibitors. Similar findings have been reported by Bello-Reuss and coworkers, who showed an inhibition of aldosterone secretion from $\mathrm{NCl}-\mathrm{H} 295 \mathrm{R}$ cells in the presence of MDR1 inhibitors in the culture medium (Bello-Reuss et al. 2000).

However, the importance of Pgp as a steroid transporter is questioned as the mdr1b knockout mice and the mdr1a/b double knockout mice showed no gross disturbances in corticosteroid handling. However, there was a report of consistently lower ACTH and corticosterone plasma levels in mdr1a/b double knockouts as compared to their wild type (Muller et al. 2003), suggesting an alteration on hypothalamic-pituitaryadrenal axis (HPA-axis) regulation. The lack of gross changes in glucocorticoid targets was reported, which suggests that both mdr1a and mdr1b have no essential function in the normal steroid metabolism of the adrenal (Schinkel et al. 1997). VanKalken and colleagues and later Ambudkar and coworkers proposed that Pgp might be involved in steroid transport for protecting the plasma membranes of steroid secreting cells from the toxic effects of high steroid concentrations (Ambudkar et al. 1999; Vankalken et al. 1993) under conditions of, e.g., stress-induced HPA-axis activity. Karssen proposed that Pgp may be playing a role in the regulation of glucocorticoid exposure of glucocorticoid responsive cells like neurons (Karssen et al. 2001). Taking together all this discussion, the extent of how much MDR1 is 
involved in cortisol release is still to be determined. However, a protective role of Pgp would also be more fitting with its property to transport drugs out of the plasma membrane.

\subsection{DHEAS INDUCED CORTISOL RELEASE}

Dehydroepiandrosterone (DHEA) and its sulfated ester, DHEAS, are endogenous hormones, both synthesized and released from zona reticularis in response to ACTH (Nieschlag et al. 1973). Pregnenolone is the precursor to DHEA as well as other androgens, mineralocorticoids, and glucocorticoids. Pregnenolone is derived from cholesterol after side chain cleavage by cytochrome CYP11A1. CYP17, a 17ahydroxylase with 17,20-desmolase activity, catalyzes the synthesis of DHEA from pregnenolone. Hydrosteroid sulfatases convert DHEA to DHEAS, which is the most abundant circulating steroid hormone in human (Nieschlag et al. 1973; Regelson et al. 1994). The adrenal cortex is the primary source of DHEA and DHEAS, but some is also produced in the testes (Vermeulen et al. 1982). Once in the circulation, DHEAS can be metabolized back to DHEA by sulfohydrolases in peripheral and adrenal tissues (Kishimoto et al. 1972). DHEA is a precursor for many other steroids. It is changed into androstenedione, androsterone, testosterone, and estradiol by the action of CYP19 and 17ßHSD enzymes (Harvey 1996; Kroboth et al. 1999; Rainey et al. 2002; Wilson et al. 1992).

\subsubsection{Effect of DHEAS treatment of cortisol release from $\mathrm{NCl}-$ H295R cells}

As a substrate of hOAT3 we checked the influence of DHEAS and estrone sulfate on cortisol release from $\mathrm{NCl}-\mathrm{H} 295 \mathrm{R}$ cells. An unexpected observation was, that preincubation of $\mathrm{NCl}-\mathrm{H} 295 \mathrm{R}$ cells with DHEAS did not inhibit cortisol release but resulted in 10 fold greater cortisol release than in cells not exposed to DHEAS. When DHEAS was added in the presence of forskolin, an additive effect on cortisol release was observed. The cortisol release from DHEAS plus forskolin-pretreated cells was 6-10 fold greater than in cells only pretreated with forskolin. This reflects an additive effect of DHEAS on the cortisol release in forskolin stimulated cells.

In contrast, experiments on rat zona fasciculata-reticularis cells showed a significant decrease in corticosterone release by DHEA treatment (Chang et al. 2003). The exact mechanism, how DHEA or DHEAS influence cortisol or corticosterone synthesis is still not clear. 


\subsubsection{Effect of DHEAS treatment on enzymes of steroid biosynthesis}

To elucidate, how DHEAS treatment increased the cortisol release from $\mathrm{NCl}-\mathrm{H} 295 \mathrm{R}$ cells, we performed RT-PCR studies of potent enzymes of steroid biosynthesis. We found a slight but significant increase in the StAR mRNA. The StAR protein is involved in the cholesterol translocation from cytosol to the mitochondria and serves as a rate-limiting step in steroid biosynthesis. There was a not significant 2 fold increase in the mRNA of CYP11B1 (Table 4.2), the last key enzyme in the cortisol biosynthesis which converts 11-deoxycortisol to cortisol. One interpretation of these results would be, that increased expression of StAR mRNA enhanced the cortisol syntheses in $\mathrm{NCl}-\mathrm{H} 295 \mathrm{R}$ cells. Chang and co-workers recently reported no change in mRNA expression of CYP11A1 and StAR by DHEA treatment on the rat zona fasciculata-reticularis cells. However, the protein expression for StAR was decreased by DHEA treatment, while CYP11A1 protein remained unchanged (Chang et al. 2003). At present, we do not know whether there are species differences (human versus rats) or differences between the cell line and the rat adrenal cells.

\subsubsection{Effect of DHEAS treatment on organic anion transporters}

DHEAS is a potent substrate of OAT3, OAT4 and many members of OATP family (Burckhardt et al. 2003; Hagenbuch et al. 2003; Ugele et al. 2003; van Montfoort et al. 2002). After observing the influence of DHEAS on cortisol release and on some of the steroid biosynthesis enzymes, we checked its effect on mRNA expression of organic anion transporters. The results demonstrated that from the expressed transporters (OAT3, OAT4, OATP-A and MDR1) only OAT4 expression was upregulated by $39 \%$ with DHEAS treatment. There was a $53 \%$ increase in the mRNA of hOAT3 that was, however, not significant. The immunoblotting for hOAT3 expression in DHEAS treated NCl-H295R cells did not show a significant increase of hOAT3 protein as compared to not-treated control cells. The blotting showed many bands and it is difficult to draw any specific conclusion from these results. Immunofluorescence studies with of $\mathrm{NCl}-\mathrm{H} 295 \mathrm{R}$ cells showed a significant increase in the labelling for hOAT3 by treatment of cells with DHEAS. The immunostaining was almost completely abolished by antigen peptide saturation. DHEAS induced upregulation of hOAT3 was quite apparent, but the mechanism how it is happening is not yet clear. 


\subsection{EFFECT OF FORSKOLIN TREATMENT ON NCI-H295R CELLS}

\subsubsection{Effect of forskolin treatment on steroid biosynthesis enzymes}

$\mathrm{NCl}-\mathrm{H} 295 \mathrm{R}$ cell line secretes steroids of the mineralcorticoid, glucocorticoid and adrenal androgen pathways. These cells are known to express ACTH-receptors at low level but the agonistic effects of ACTH in vivo, i.e., elevation of cAMP and activation of protein kinase $A$, can be reproduced fully by forskolin or dibutyryl cyclic adenosine monophosphate (dbcAMP) (Rainey et al. 1994). We have seen a 25 fold greater cortisol release by $24 \mathrm{~h}$ treatment with forskolin. We investigated the effect of $24 \mathrm{~h}$ forskolin treatment of $\mathrm{NCl}-\mathrm{H} 295 \mathrm{R}$ cells on the key enzymes of steroid biosynthesis and observed a highly significant $(80 \%)$ increase in $3 \beta H S D$ enzymes. The increase in mRNA for StAR, CYP21A2, CYP17, CYP11A1 and CYP11B1 was $25 \%, 55 \%, 45 \%, 13 \%$, and $80 \%$, respectively, all in the significance range. The results are in agreement with what was previously reported for forskolin stimulation in primary adrenal as well as in $\mathrm{NCl}-\mathrm{H} 295 \mathrm{R}$ cells. Stimulation of $\mathrm{NCl}-\mathrm{H} 295 \mathrm{R}$ cells with forskolin induced a 1.5 fold increase in StAR mRNA (Zenkert et al. 2000). Bird and co-workers reported a dramatic increase in expression of CYP21A2, CYP17, CYP11A1, CYP11B1 and CYP11B2 enzymes by forskolin as well as by dbcAMP (Bird et al. 1998a). Similar results were found in many other reports about forskolin treatment resulting in higher expression of enzymes of glucocorticoids biosynthesis (Bird et al. 1993; Bird et al. 1998b; Denner et al. 1996; Rainey et al. 1993).

\subsubsection{Effect of forskolin treatment on organic anion transporters}

We found a $25 \%$ increase in radiolabeled estrone sulfate and $\mathrm{PAH}$ uptake in $\mathrm{NCl}-$ H295R cells. The steroid biosynthesis enzymes were also regulated by treatment with forskolin. In order to clarify the effect of forskolin on transporter proteins, we stimulated the $\mathrm{NCl}-\mathrm{H} 295 \mathrm{R}$ cells with forskolin for $24 \mathrm{~h}$ and performed a semiquantitative RT-PCR for OAT3, OAT4, OATP-A, and MDR1 expression. We observed a significant increase $(21 \%)$ in hOAT3 expression in $\mathrm{NCl}-\mathrm{H} 295 \mathrm{R}$ cells. There was no significant difference in mRNA expression of hOAT4 and OATP-A. The forskolin treatment effects were more prominent in hOAT3 protein expression. The immunoblotting experiments showed a more than two fold increase in hOAT3 expression. The immunolocalization for hOAT3 resulted in a very high staining of the cells after forskolin treatment. Thus similar results obtained with DHEAS and 
forskolin treatment, suggesting a common but not yet clear mechanism of increase in hOAT3 expression.

The most of hOAT3 immunostaining was observed intercellularly, rather than on the plasma membrane in control, forskolin and DHEAS treated cells, which might indicate some additional assignments of hOAT3 in the steroid producing cells. As most of the steroid synthesis takes place in two distinct organelles of the adrenocortical cells, i.e., mitochondria and endoplasmic reticulum, a shuttling of intermediate products of steroid biosynthesis between mitochondria to endoplasmic reticulum and back take place (Stocco 2000; Wilson et al. 1992). It is tempting to speculate that OAT3 is involved in this shuttling process.

The presence of cAMP responsive elements and of steroidgenic factor 1 binding sequences in OAT3 promoter region would provide the basis for the regulation of hOAT3 gene by forskolin. Forskolin directly stimulates adenylyl cyclase and has been used extensively to increase CAMP. The subsequent rise in intracellular cAMP concentration results in the activation of protein kinase $A(P K A)$ and the translocation of active catalytic subunits of PKA into the nucleus. PKA phosphorylates and thereby stimulates transcriptional activators that bind as dimers to cAMP-responsive elements (CREs) (Riabowol et al. 1988). Presence of CREs in the promoter region should induce the transcription of hOAT3. Another possibility is regulation through steroidgenic factor 1 binding sequence (also called Ad4BP) in hOAT3 promoter region. This is a nuclear receptor half-site, which binds the steroidgenic factor-1 (Bassett et al. 2002). SF-1 is a nuclear transcription factor that was first identified in adrenocortical cells (Morohashi et al. 1993). The SF-1 plays a critical role in adrenal and gonadal differentiation, development, and function. Furthermore, SF-1 has also been shown to regulate the expression of genes encoding cytochrome P450 hydroxylases and to efficiently transactivate the StAR gene in transient transfection assays in various cell types (Bassett et al. 2002; Rust et al. 1998; Sandhoff et al. 1998).

In an attempt to explore these possibilities, we made an in silico analysis and identified three cAMP-responsive elements sequences and one steroidogenic factor 1 binding sequence in 3.2-kb long hOAT3 promoter region (unpublished data, Dr. Bahn, University of Göttingen). These findings provides a possible pathway of forskolin induced upregulation of hOAT3 protein.

$24 \mathrm{~h}$ treatment with forskolin increased the expression for MDR1 mRNA by 37\% over non-stimulated control cells. These results are in good agreement, with what has been reported earlier in Chag liver cells. Forskolin increased the mRNA level of MDR1, which was decreased, when an inhibitor of protein kinase $A$ was used in 
addition (Suzuki et al. 2003). How much the higher expression of MDR1 by forskolin contributes to cortisol release is not known.

\subsection{EFFECT OF FORSKOLIN AND DHEAS TREATMENT ON NCI-H295R CELLS AT PROTEOME LEVEL}

The effect of forskolin and DHEAS treatment was investigated on mRNA expression of transporters and steroid biosynthesis enzymes, but naturally it is most important to determine the changes at the protein level. Studies done on yeast showed that protein and mRNA responses were correlated in some, but not in other cases (Ideker et al. 2000; Ideker et al. 2001). Some genes showed changes in mRNA without changes in protein, whereas others showed changes in protein abundance without changes in mRNA levels. Therefore, only looking at mRNA levels one obtains a limited view of cellular regulation. As we have discussed earlier, forskolin induces cAMP elevation and consequently influences many important aspects of the cells (Barovsky et al. 1983; Bird et al. 1998a; Boige et al. 1983; Cobb et al. 1997; Laurenza et al. 1989; Zenkert et al. 2000). For this reason, SELDI-TOF and MALDITOF techniques were used to monitor the protein expression under forskolin and DHEAS treatment.

\subsubsection{SELDI-TOF analysis of proteins}

SELDI-TOF technique allows to capture proteins on a range of chromatography chip surfaces, both chemical and biochemical, and then to analyse them by time of flight mass spectrometry (Fung et al. 2003).

In the present study the $\mathrm{H} 50$ ProteinChip ${ }^{\circ}$ array was used which binds proteins through reversed phase or hydrophobic interaction chromatography. The output data was obtained in two formats, raw spectrum or grey-scale (represents a stained onedimensional electrophoresis gel, also called "gel-view"). The forskolin, DHEAS treated, or not treated control cells were divided into cytosol and membrane enriched fractions by ultra-centrifugation. There was almost no protein, shared by both cytosolic and membrane fractions. The results demonstrated a number of proteins, which were significantly changed by forskolin or DHEAS treatment. Two proteins were highly expressed in the forskolin stimulated cytosol fraction, while one protein was upregulated in the cytosol fraction of only the DHEAS treated cells.

The results from membrane-enriched fractions showed four proteins, with high intensity after forskolin stimulation, while one protein was downregulated in both 
DHEAS and forskolin stimulated cells. The identity of these regulated proteins is yet to be determined. This technique could provide a broader view of changes induced by any stimuli i.e., forskolin, in the future.

\subsubsection{MALDI-TOF analysis of proteins}

MALDI-TOF analysis in combination with one-dimensional (1-D) and two dimensional (2-D) gel electrophoresis is the major technique in qualitative and quantitative general protein expression analysis. 2-DE is a method for the separation of proteins in a sample by displacement in two dimensions oriented at right angles to one another. This allows the sample to separate over a larger area, increasing the resolution of each component. The separated spots are then cut from the gel and digested by protease, like trypsin into a number of smaller peptides. These digested peptides are then extracted and analysed by MALDI-TOF to measure the peptide masses. This set of masses is then used to identify the matching proteins via web based protein databases.

The analysis of P450 isozymes (CYP) and transporters proteins presented considerable difficulties. They are membrane proteins that are expressed in varying amounts and several attempts at 2-DE analysis of liver microsomes and purified P450 are described in the literature (Galeva et al. 2002; Vlasuk et al. 1982). In the beginning of the 90s, Anderson and co-workers published the 2-DE map of rat liver proteins (Anderson et al. 1991; Anderson et al. 1995). However, only two ER membrane proteins were identified on this map. Many reports have emerged in the recent years about the combined use of $1 \mathrm{DE}$ and $2 \mathrm{DE}$ to identify membrane proteins due to their difficulty to be separated on 2-DE (Fey et al. 2001; Fountoulakis et al. 2002; Galeva et al. 2002). Based on circumstantial evidence, in the present study we used both methods to identify the membrane transporter, steroid biosynthesis enzymes proteins, and their regulation by forskolin and DHEAS stimulation. The membrane enriched fractions of $\mathrm{NCl}-\mathrm{H} 295 \mathrm{R}$ cell, prepared after 24 hours stimulation with forskolin, DHEAS, or without stimulation, were separated by 1-D and 2D electrophoresis.

We tried several procedures of 2-DE and modifications to standardized 2-DE for improved separation of $\mathrm{NCl}-\mathrm{H} 295 \mathrm{R}$ membrane proteins. Our results for membrane 2DE yeilded 250 individual spots, 140 of them have been identified so far. Mostly membrane proteins and membrane binding proteins are among them, but no particular cytochrome P450 enzyme or organic anion transporter protein. By 1-DE, we identified two important members of cytochrome P450 enzymes (CYP11A1 and CYP21A). As single bands in the 1-DE samples contain more than one protein, it is 
difficult to speculate about any protein regulation in $\mathrm{NCl}-\mathrm{H} 295 \mathrm{R}$ cells by forskolin and DHEAS. As to our knowledge there have been only a few reports on hepatic cytochrome P450 enzymes (Galeva et al. 2003), but no report about identification of adrenal cytochrome P450 enzymes.

\subsection{THE OUTLOOK}

The efflux of cortisol at adrenal cell membrane is in part mediated through hOAT3. However, the high intercellular labelling of hOAT3 in NCl-H295R cells suggests a role also in intra-organelle shuttling of intermediate products of steroid biosynthesis.

A surprising increase in cortisol release and expression of hOAT3 in NCl-H295R cells by DHEAS treatment was observed, while the effect of DHEAS treatment on steroid biosynthesis enzymes was limited to a slight increase in StAR mRNA. This study provides a basis for further investigations on DHEAS treatment on adrenal cells on RNA and proteome levels.

Forskolin stimulated cortisol release, the expression of OAT3 and mRNA of key enzymes of steroid biosynthesis in NCl-H295R cells. How protein expression is changed is yet not clear. The proteomic studies by using SELDI-TOF and MALDITOF provide a suitable tool to study these changes. 
6 APPENDIX

\begin{tabular}{|c|c|c|c|c|}
\hline $\begin{array}{l}\text { Spot } \\
\text { No. }\end{array}$ & Protein Identity & $\begin{array}{l}\text { Molecular } \\
\text { Mass kDa }\end{array}$ & $\begin{array}{l}\text { PubMed } \\
\text { Accession } \\
\text { No. }\end{array}$ & Score \\
\hline 1 & $\begin{array}{l}\text { Phosphatidylethanolamine-binding } \\
\text { protein (PEBP) }\end{array}$ & 20913 & P30086 & 84 \\
\hline 2 & Annexin V (Rhombohedral Crystal Form) & 35482 & P30087 & 226 \\
\hline 3 & dnaK-type molecular chaperone HSPA5 & 72071 & P30088 & 161 \\
\hline 4 & Phosphopyruvate hydratase alpha & 47139 & A29170 & 180 \\
\hline 5 & Phosphoserine aminotransferase & 40397 & AAN71736 & 151 \\
\hline 6 & 3-phosphoglycerate dehydrogenase & & AAB88664 & 113 \\
\hline 7 & Calumenin & 37050 & AAB97725 & 85 \\
\hline 8 & ALG-2 interacting protein 1 & 96019 & AAF08220 & 218 \\
\hline 10 & apg-2 & 94240 & BAA75062 & 104 \\
\hline 13 & Heat shock protein 90-alpha - human & 84607 & HHHU86 & 143 \\
\hline 14 & $\begin{array}{l}\text { Heat shock protein HSP } 90 \text {-alpha (HSP } \\
\text { 86) }\end{array}$ & 84490 & P07900 & 116 \\
\hline 16 & $\begin{array}{l}\text { Transitional endoplasmic reticulum } \\
\text { ATPase }\end{array}$ & 89266 & T02243 & 141 \\
\hline 17 & dnaK-type molecular chaperone & 70854 & A27077 & 131 \\
\hline 21 & Oxygen-regulated protein $150 \mathrm{~K}$ precursor & 111266 & JC5278 & 115 \\
\hline 22 & Talin & 269486 & AAF27330 & 114 \\
\hline 23 & Fatty acid synthase & 273227 & AAH63242 & 134 \\
\hline 25 & Protein disulfide-isomerase ER60 & 56761 & JC5704 & 209 \\
\hline 26 & protein disulfide-isomerase & 57081 & ISHUSS & 291 \\
\hline 28 & tubulin alpha chain - marbled electric ray & 42676 & S33517 & 134 \\
\hline 29 & Beta 5-tubulin chaperonin GroEL & 61016 & A32800 & 125 \\
\hline 30 & $\begin{array}{l}\text { FK506-binding protein } 4 \text { (Peptidyl-prolyl } \\
\text { cis-trans isomerase) (PPlase) }\end{array}$ & 51641 & Q02790 & 197 \\
\hline 31 & $\begin{array}{l}\text { (Rotamase) (p59 protein) (HSP binding } \\
\text { immunophilin) (HBI) }\end{array}$ & & A46372 & 213 \\
\hline 32 & $\begin{array}{l}\text { Hydroxymethylglutaryl-CoA synthase, } \\
\text { cytosolic, adrenal isoform }\end{array}$ & $\begin{array}{l}56203 \\
57257\end{array}$ & $\begin{array}{l}\text { Q8N995 } \\
\text { S45497 }\end{array}$ & 90 \\
\hline 35 & Inhibitor-2 of protein phosphatase-2A. & 32084 & AAQ79833 & 53 \\
\hline 36 & PHAPI protein - (fragments) & 24053 & S36375 & 107 \\
\hline 37 & Tripartite motif protein TRIM13 beta & 19828 & AAG53501 & 137 \\
\hline 41 & Unnamed protein product & 43553 & CAC88592 & 42 \\
\hline 42 & rho protein GDP-dissociation inhibitor 1 & 23193 & I38156 & 122 \\
\hline 43 & GTP binding protein RanBP1 - & 23296 & S54290 & 58 \\
\hline 45 & Proteasome activator PA28 beta & 27344 & AAF02218 & 117 \\
\hline 44 & RNCC protein & 26906 & CAB46078 & 98 \\
\hline 47 & $\begin{array}{l}\text { Platelet-activating factor acetylhydrolase } \\
\text { Ib beta chain - human }\end{array}$ & 25553 & JC5409 & 77 \\
\hline 48 & Proteasome activator PA28 alpha chain & 28705 & A54859 & 51 \\
\hline 49 & Glutathione transferase omega & 27548 & AAF73376 & 48 \\
\hline 50 & Aryl sulfotransferase (EC 2.8.2.1) HAST2 & 34156 & JC5248 & 74 \\
\hline 51 & Thiol-specific antioxidant protein] & 21843 & CAA80269 & 80 \\
\hline 52 & Triosephosphate isomerase (TIM) & 26522 & P60174 & 135 \\
\hline 53 & Phosphoglycerate mutase (EC 5.4.2.1) B & 28786 & PMHUYB & 158 \\
\hline 54 & $\begin{array}{l}\text { Chain C, Structure Of The Ran-Gppnhp- } \\
\text { Ranbd1 Complex }\end{array}$ & 20557 & 1RRPC & 136 \\
\hline 55 & $\begin{array}{l}\text { platelet-activating factor acetylhydrolase } \\
\text { (EC 3.1.1.-) gamma chain }\end{array}$ & 25718 & JC4246 & 64 \\
\hline 56 & $\begin{array}{l}\text { Peroxiredoxin } 6 \text { (Antioxidant protein 2) } \\
\text { (Acidic calcium-independent } \\
\text { phospholipase A2) }\end{array}$ & 25019 & P30041 & 105 \\
\hline 57 & Peroxiredoxin 6 & 25019 & AAH35857 & 159 \\
\hline
\end{tabular}




\begin{tabular}{|c|c|c|c|c|}
\hline $\begin{array}{l}\text { Spot } \\
\text { No. }\end{array}$ & Protein Identity & $\begin{array}{l}\text { Molecular } \\
\text { Mass kDa }\end{array}$ & $\begin{array}{l}\text { PubMed } \\
\text { Accession } \\
\text { No. }\end{array}$ & Score \\
\hline 58 & Triosephosphate isomerase (TIM) & 26625 & P60174 & 66 \\
\hline 59 & Inorganic pyrophosphatase & 32639 & AAP97214 & 168 \\
\hline 60 & $\begin{array}{l}\text { L-lactate dehydrogenase B chain (LDH- } \\
\text { B) ( } \mathrm{LDH} \text { heart subunit) }(\mathrm{LDH}-\mathrm{H})\end{array}$ & 36484 & P07195 & 111 \\
\hline 63 & Cargo selection protein TIP47 & 47004 & AAC39751 & 115 \\
\hline 65 & Creatine kinase- $B$ & 42460 & AAA76850 & 73 \\
\hline 66 & Actin beta - human & 41766 & ATHUB & 102 \\
\hline 67 & Unnamed protein product & 77340 & CAD70046 & 51 \\
\hline 68 & $\begin{array}{l}\text { Ubiquitin-like } 1 \text { activating enzyme E1A } \\
\text { (SUMO-1 activating enzyme subunit } 1 \text { ). }\end{array}$ & 38394 & Q9UBE0 & 154 \\
\hline 69 & Spermine synthase & 41242 & АAН09898 & 72 \\
\hline 70 & Spermine synthase (EC 2.5.1.22) & 41396 & S54160 & 95 \\
\hline 71 & 38K protein - hum... [gi:25527053] & 38250 & JC7769 & 129 \\
\hline 72 & $\begin{array}{l}\text { Human protein: Q8IV48 - Similar to } \\
\text { RIKEN cDNA 3110010F15 gene ( } 3 \text { ' } \\
\text { exoribonuclease). }\end{array}$ & 40038 & Q8IV48 & 70 \\
\hline 73 & Capping protein a...[gi:7448799] & 32902 & G02639 & 78 \\
\hline 74 & Hepatoma-derived growth factor - & 26772 & A55055 & 126 \\
\hline 75 & Nucleophosmin & 32583 & AAQ24860 & 76 \\
\hline 76 & $\begin{array}{l}\text { Ferredoxin reductase, isoform } 1 \\
\text { precursor }\end{array}$ & 53803 & AAH02960 & 194 \\
\hline 77 & $\begin{array}{l}\text { Human protein: Q96FZ8 - Hypothetical } \\
\text { protein FLJ90475 (EC ) (Citrate } \\
\text { synthase). }\end{array}$ & 51680 & Q96FZ8 & 90 \\
\hline 78 & Fumarate hydratase precursor & 54602 & AAH03108 & 97 \\
\hline 79 & $\begin{array}{l}\text { Fascin (Singed-like protein) ( } 55 \mathrm{kDa} \text { actin } \\
\text { bundling protein) (p55) }\end{array}$ & 54365 & Q16658 & 87 \\
\hline 80 & $\begin{array}{l}\text { Transformation-sensitive protein IEF SSP } \\
3521\end{array}$ & 62599 & A38093 & 94 \\
\hline 81 & $\begin{array}{l}\text { Gonadotropin inducible transcription } \\
\text { repressor- } 4\end{array}$ & & BAA86990 & 45 \\
\hline 82 & $\begin{array}{l}\text { Human protein: Q9UQ37 - RNA binding } \\
\text { protein (Fragment). }\end{array}$ & 85568 & Q9UQ37 & 40 \\
\hline 83 & Glucose-6-phosphate 1-dehydrogenase & 59219 & NP_789359 & 200 \\
\hline 84 & $\begin{array}{l}\text { Fascin (Singed-like protein) (55 kDa actin } \\
\text { bundling protein) }\end{array}$ & 54365 & Q16̄658 & 88 \\
\hline 85 & Rab GDP dissociation inhibitor beta & 41014 & AAD34588 & 209 \\
\hline 86 & EEF1G protein & 49814 & AAH07949 & 92 \\
\hline 87 & Translation elongation factor EF-Tu & 49509 & S62767 & 98 \\
\hline 88 & $\begin{array}{l}\text { Human protein: Q7Z3V0 - Hypothetical } \\
\text { protein DKFZp686M0959 }\end{array}$ & 46497 & Q7Z3V0 - & 109 \\
\hline 89 & $\begin{array}{l}\text { Human protein: Q8N1P6 - Hypothetical } \\
\text { protein FLJ38023 }\end{array}$ & 47574 & Q8N1P6 & 84 \\
\hline 90 & Aspartate transaminase & 46087 & S29027 & 213 \\
\hline 92 & $\begin{array}{l}\mathrm{N} \text {-acetylneuraminic acid phosphate } \\
\text { synthase }\end{array}$ & 40281 & AAH00008 & 130 \\
\hline 93 & $\begin{array}{l}\text { Acetyl-coenzyme A acetyltransferase } 2 \\
\text { (Acetoacetyl coenzyme A thiolase). }\end{array}$ & 41352 & Q9BWD1 & 114 \\
\hline 94 & MAP kinase & 41363 & JQ1400 & 113 \\
\hline 95 & $\begin{array}{l}\text { Human protein: Q9HC49 - CTCL tumor } \\
\text { antigen }\end{array}$ & 63937 & Q9HC49 & 42 \\
\hline 96 & Ran GTPase activator 1 & 63502 & JC5300 & 62 \\
\hline 97 & $\begin{array}{l}\text { Aldose reductase (AR) (Aldehyde } \\
\text { reductase) }\end{array}$ & 35573 & P15121 & 139 \\
\hline 98 & $\begin{array}{l}\text { Novel protein similar to human glyoxylate } \\
\text { reductase/hydroxypyruvate reductase }\end{array}$ & 35646 & CAE30406 & 110 \\
\hline
\end{tabular}




\begin{tabular}{|c|c|c|c|c|}
\hline $\begin{array}{l}\text { Spot } \\
\text { No. }\end{array}$ & Protein Identity & $\begin{array}{l}\text { Molecular } \\
\text { Mass kDa }\end{array}$ & $\begin{array}{l}\text { PubMed } \\
\text { Accession } \\
\text { No. }\end{array}$ & Score \\
\hline 99 & LOC117584 protein & 34787 & AAH15681 & 42 \\
\hline 100 & Biliverdin reductase & 33437 & G02066 & 78 \\
\hline 102 & Glucosidase II & 106833 & CAA04006 & 79 \\
\hline & Hypothetical protein FLJ23707 & 115113 & Q8TEB3 & 51 \\
\hline 104 & $\begin{array}{l}\text { Glycine-tRNA ligase (EC 6.1.1.14) } \\
\text { precursor }\end{array}$ & 83087 & A55314 & 115 \\
\hline 105 & Ezrin (p81) (Cytovillin) (Villin 2). & 69225 & P15311 & 69 \\
\hline 106 & Radixin & 68522 & AAH47109 & 93 \\
\hline 107 & $\begin{array}{l}\text { Moesin (Membrane-organizing extension } \\
\text { spike protein). }\end{array}$ & 67647 & P26038 & 84 \\
\hline 108 & Hypothetical protein DKFZp762H157.1 & 73890 & T47177 & 46 \\
\hline 109 & $\begin{array}{l}\text { Tumor necrosis factor type } 1 \text { receptor } \\
\text { associated protein }\end{array}$ & 79961 & AAF15314 & 209 \\
\hline 112 & Elongation factor, RNA polymerase II, 2 & 72310 & AAH28412 & 49 \\
\hline 113 & Unknown (protein ...[gi:33873708] & 61341 & AАH07952 & 101 \\
\hline 114 & $\begin{array}{l}\text { Pyruvate kinase, } \mathrm{M} 1 \text { isozyme (Pyruvate } \\
\text { kinase muscle isozyme) (Cytosolic } \\
\text { thyroid hormone-binding protein) }\end{array}$ & 57769 & P14618 & 94 \\
\hline 115 & $\begin{array}{l}\text { Pyruvate kinase, M1 isozyme (Pyruvate } \\
\text { kinase muscle isozyme) (Cytosolic } \\
\text { thyroid hormone-binding protein) } \\
\text { (CTHBP) (THBP1) }\end{array}$ & 57769 & P14618 & 95 \\
\hline 116 & Hypothetical protein & 61668 & CAD38677 & 54 \\
\hline 117 & $\begin{array}{l}\text { Glycine hydroxymethyltransferase (EC } \\
2.1 .2 .1) \text { precursor, mitochondrial }\end{array}$ & 52429 & B46746 & 183 \\
\hline 119 & $\begin{array}{l}\text { Aspartate transaminase (EC 2.6.1.1) } \\
\text { precursor, mitochondrial }\end{array}$ & 47445 & XNHUDM & 150 \\
\hline 120 & phosphoglycerate kinase & 44586 & KIHUG & 194 \\
\hline 121 & $\begin{array}{l}\text { Fructose-bisphosphate aldolase A } \\
\text { (Muscle-type aldolase) }\end{array}$ & 39264 & P04075 & 131 \\
\hline 122 & $\begin{array}{l}\text { Glyceraldehyde 3-phosphate } \\
\text { dehydrogenase, liver (GAPDH) }\end{array}$ & 35899 & P04406 & 77 \\
\hline 123 & $\begin{array}{l}\text { L-lactate dehydrogenase A chain (LDH- } \\
\text { A) (LDH muscle subunit) (LDH-M) }\end{array}$ & 36534 & P00338 & 173 \\
\hline 124 & $\begin{array}{l}\text { 3-hydroxyacyl-CoA dehydrogenase (EC } \\
\text { 1.1.1.35), short chain-specific, precursor }\end{array}$ & 34265 & JC4879 & 58 \\
\hline 125 & $\begin{array}{l}\text { Carbonyl reductase [NADPH] } 1 \text { (NADPH- } \\
\text { dependent carbonyl reductase } 1)\end{array}$ & 30225 & P16152 & 140 \\
\hline 126 & Protein kinase (EC 2.7.1.37) cdc2 - & 34074 & A29539 & 186 \\
\hline 131 & Tryptophan-tRNA ligase & 53132 & A41706 & 59 \\
\hline 132 & Phosphoglycerate dehydrogenase & 56614 & АAH00303 & 64 \\
\hline 133 & Succinyl-CoA:3-ketoacid CoA transferase & 56122 & BAB13733 & 47 \\
\hline 137 & Tyrosyl-tRNA synthetase & 59106 & AAH01933 & 85 \\
\hline 139 & $\begin{array}{l}\text { Malate dehydrogenase (oxaloacetate- } \\
\text { decarboxylating) (NADP) }\end{array}$ & 64109 & S44415 & 90 \\
\hline 140 & Unnamed protein product & 52746 & CAE89667 & 154 \\
\hline
\end{tabular}

Appendix 1 List of proteins identified from 2-D gel of TCM fraction of NCl-H295R cells. The proteins identified from 2-D gel of TCM fraction of NCl-H295R cells with spot identity corresponding to the location of the spot on gel. The missing spots numbers did not yield enough peptides to make identification. The PubMed accession numbers, molecular mass and match score have been given for each spot. The score above 65 is significant $(\mathrm{P}<$ 0.05). 


\section{REFERENCES}

1. Abe, T., Kakyo, M., Tokui, T., Nakagomi, R., Nishio, T., Nakai, D., Nomura, H., Unno, M., Suzuki, M., Naitoh, T., Matsuno, S., and Yawo, H.11-6-1999. Identification of a novel gene family encoding human liver-specific organic anion transporter LST-1. The Journal of Biological Chemistry 274(24), 17159-17163.

2. Ambudkar, S. V., Dey, S., Hrycyna, C. A., Ramachandra, M., Pastan, I., and Gottesman, M. M.1999. Biochemical, cellular, and pharmacological aspects of the multidrug transporter. Annu.Rev Pharmacol Toxicol. 39, 361-398.

3. Anderson, N. L., Esquer-Blasco, R., Hofmann, J. P., and Anderson, N. G.1991. A two-dimensional gel database of rat liver proteins useful in gene regulation and drug effects studies. Electrophoresis 12(11), 907-930.

4. Anderson, N. L., Esquer-Blasco, R., Hofmann, J. P., Meheus, L., Raymackers, J., Steiner, S., Witzmann, F., and Anderson, N. G.1995. An updated two-dimensional gel database of rat liver proteins useful in gene regulation and drug effect studies. Electrophoresis 16(10), 1977-1981.

5. Arnold, J.1866. Ein beitrag zu der feineren structure und dem chemismus der nebennirren. Virchows Arch Pathol Anat Physiol 39, 64-117.

6. Bahn, A., Knabe, M., Hagos, Y., Rodiger, M., Godehardt, S., Graber-Neufeld, D. S., Evans, K. K., Burckhardt, G., and Wright, S. H.2002b. Interaction of the metal chelator 2,3-dimercapto-1-propanesulfonate with the rabbit multispecific organic anion transporter 1 (rbOAT1). Molecular Pharmacology 62(5), 1128-1136.

7. Bahn, A., Knabe, M., Hagos, Y., Rodiger, M., Godehardt, S., Graber-Neufeld, D. S., Evans, K. K., Burckhardt, G., and Wright, S. H.2002a. Interaction of the metal chelator 2,3-dimercapto-1-propanesulfonate with the rabbit multispecific organic anion transporter 1 (rbOAT1). Mol Pharmacol 62(5), 1128-1136.

8. Bakhiya, A., Bahn, A., Burckhardt, G., and Wolff, N.2003. Human Organic Anion Transporter 3 (hOAT3) can Operate as an Exchanger and Mediate Secretory Urate Flux. Cell Physiol Biochem. 13(5), 249-256.

9. Barovsky, K., Pedone, C., and Brooker, G.1983. Forskolin-Stimulated Cyclic-Amp Accumulation and Forskolin-Potentiated Hormone Action Occur by Different Mechanisms. Federation Proceedings 42(5), 1366.

10. Bassett, J. R. and Pollard, I.1980. The involvement of coated vesicles in the secretion of corticosterone by the zona fasciculata of the rat adrenal cortex. Tissue Cell 12(1), $101-115$.

11. Bassett, M. H., Zhang, Y., Clyne, C., White, P. C., and Rainey, W. E.2002. Differential regulation of aldosterone synthase and 11beta-hydroxylase transcription by steroidogenic factor-1. J.Mol.Endocrinol. 28(2), 125-135.

12. Baxter, J. D. and Rousseau, Guy G.1979. Glucocorticoid hormone action. 25-49. Berlin ; New York, Springer-Verlag. Monographs on endocrinology.

13. Beato, M.10-2-1989. Gene regulation by steroid hormones. Cell 56(3), 335-344. 
14. Beery, E., Middel, P., Bahn, A., Willenberg, H. S., Hagos, Y., Koepsell, H., Bornstein, S. R., Muller, G. A., Burckhardt, G., and Steffgen, J.2003. Molecular evidence of organic ion transporters in the rat adrenal cortex with adrenocorticotropin-regulated zonal expression. Endocrinology 144(10), 4519-4526.

15. Belanoff, J. K., Gross, K., Yager, A., and Schatzberg, A. F.2001. Corticosteroids and cognition. J Psychiatr.Res. 35(3), 127-145.

16. Bello-Reuss, E., Ernest, S., Holland, O. B., and Hellmich, M. R.2000. Role of multidrug resistance P-glycoprotein in the secretion of aldosterone by human adrenal $\mathrm{NCl}-\mathrm{H} 295$ cells. American Journal of Physiology-Cell Physiology 278(6), C1256C1265.

17. Bird, I. M., Hanley, N. A., Word, R. A., Mathis, J. M., Mccarthy, J. L., Mason, J. I., and Rainey, W. E.1993. Human Nci-H295 Adrenocortical Carcinoma-Cells - A Model for Angiotensin-li-Responsive Aldosterone Secretion. Endocrinology 133(4), 1555-1561.

18. Bird, I. M., Mason, J. I., and Rainey, W. E.1998a. Battle of the kinases: integration of adrenal responses to cAMP, DG and $\mathrm{Ca} 2+$ at the level of steroidogenic cytochromes P450 and 3betaHSD expression in H295R cells. Endocr.Res. 24(3-4), 345-354.

19. Bird, I. M., Mason, J. I., and Rainey, W. E.1998b. Protein kinase A, protein kinase C, and $\mathrm{Ca}(2+)$-regulated expression of 21-hydroxylase cytochrome P450 in $\mathrm{H} 295 \mathrm{R}$ human adrenocortical cells. J.Clin.Endocrinol.Metab 83(5), 1592-1597.

20. Blum, H., Beier, H., and Gross, H. J.1987. Improved Silver Staining of Plant-Proteins, Rna and Dna in Polyacrylamide Gels. Electrophoresis 8(2), 93-99.

21. Boige, N., Munck, A., Amiranoff, B., and Laburthe, M.1983. The Action of Forskolin on Human Intestinal Adenylate-Cyclase - Stimulation of Basal Activity and Potentialization of Activity Stimulated by Vip. Diabetes \& Metabolism 9(3), 252.

22. Bossuyt, X., Müller, M., Hagenbuch, B., and Meier, P. J.1996a. Polyspecific drug and steroid clearance by an organic anion transporter of mammalian liver. Journal of Pharmacology and Experimental Therapeutics 276, 891-896.

23. Bossuyt, X., Müller, M., and Meier, P. J.1996b. Multispecific amphipathic substrate transport by an organic anion transporter of human liver. Journal of Hepatology 25, 733-738.

24. Bradford, M. M.7-5-1976. A rapid and sensitive method for the quantitation of microgram quantities of protein utilizing the principle of protein-dye binding. Analytical Biochemistry 72, 248-254.

25. Briz, O., Serrano, M. A., Macias, R. I., Gonzalez-Gallego, J., and Marin, J. J.4-22003. Role of organic anion-transporting polypeptides, OATP-A, OATP-C and OATP8 in the human placenta-maternal liver tandem excretory pathway for foetal bilirubin. Biochemical Journal Pt, 897-905.

26. Buist, S. C., Cherrington, N. J., Choudhuri, S., Hartley, D. P., and Klaassen, C. D.2002. Gender-specific and developmental influences on the expression of rat organic anion transporters. Journal of Pharmacology and Experimental Therapeutics $301(1), 145-151$.

27. Burckhardt, B. C., Brai, S., Wallis, S., Krick, W., Wolff, N. A., and Burckhardt, G.1211-2002a. Transport of cimetidine by flounder and human renal organic anion transporter 1. Am.J.Physiol Renal Physiol , 503-509. 
28. Burckhardt, B. C., Brai, S., Wolff, N. A., and Burckhardt, G.2001a. Interaction of PAH, bumetanide, furosemide, and cimetidine with the flounder renal organic anion transporter (fROAT) [Abstract]. Journal of the American Society of Nephrology .

29. Burckhardt, B. C. and Burckhardt, G.2003. Transport of organic anions across the basolateral membrane of proximal tubule cells. Rev Physiol Biochem.Pharmacol 146, 95-158.

30. Burckhardt, G., Bahn, A., and Wolff, N. A.2001b. Molecular physiology of renal paminohippurate secretion. News Physiol Sci. 16, 114-118.

31. Burckhardt, G. and Pritchard, J. B.2000a. Organic anion and cation antiporters. Seldin, D. W. and Giebisch, G. The kidney: Physiology and pathophysiology. $\operatorname{rd}(7)$, 193-222. Philadelphia, Lippincott Williams and Wilkins.

32. Burckhardt, G. and Wolff, N. A.2000b. Structure of renal organic anion and cation transporters. Am.J.Physiol Renal Physiol 278(6), F853-F866.

33. Burckhardt, G., Wolff, N. A., and Bahn, A.2002b. Molecular characterization of the renal organic anion transporter 1. Cell Biochem. Biophys. 36(2-3), 169-174.

34. Bush, I. E.1953. Species Differences in Adrenocortical Secretion. Journal of Endocrinology 9(1), 95-\&.

35. Cha, S. H., Sekine, T., Fukushima, J. I., Kanai, Y., Kobayashi, Y., Goya, T., and Endou, H.2001. Identification and characterization of human organic anion transporter 3 expressing predominantly in the kidney. Molecular Pharmacology 59(5), $1277-1286$.

36. Cha, S. H., Sekine, T., Kusuhara, H., Yu, E., Kim, J. Y., Kim, D. K., Sugiyama, Y., Kanai, Y., and Endou, H.11-2-2000. Molecular cloning and characterization of multispecific organic anion transporter 4 expressed in the placenta. The Journal of Biological Chemistry 275(6), 4507-4512.

37. Chang, L. L., Wun, W. S., Ho, L. L., and Wang, P. S.13-11-2003. Effects of dehydroepiandrosterone on corticosterone release in rat zona fasciculata-reticularis cells. Naunyn Schmiedebergs Arch.Pharmacol. 487-495.

38. Chen, T. C., Mackic, J. B., Mccomb, J. G., Giannotta, S. L., Weiss, M. H., and Zlokovic, B. V.1996. Cellular uptake and transport of methylprednisolone at the bloodbrain barrier. Neurosurgery 38(2), 348-354.

39. Chin, J. E., Soffir, R., Noonan, K. E., Choi, K., and Roninson, I. B.1989. Structure and expression of the human MDR (P-glycoprotein) gene family. Mol.Cell Biol. 9(9), 38083820.

40. Cobb, V. J., Williams, B. C., Mason, J. I., and Walker, S. W.1997. Direct stimulation of cortisol secretion from the human $\mathrm{NCl} \mathrm{H} 295$ adrenocortical cell line by vasoactive intestinal polypeptide. J.Hypertens. 15(12 Pt 2), 1735-1738.

41. Dallman, M. F., Akana, S. F., Jacobson, L., Levin, N., Cascio, C. S., and Shinsako, J.1987. Characterization of corticosterone feedback regulation of ACTH secretion. Annals of the New York Academy of Sciences 512, 402-414.

42. Dempsher, D. P., Gann, D. S., and Phair, R. D.1984. A mechanistic model of ACTHstimulated cortisol secretion. Am.J.Physiol 246(4 Pt 2), R587-R596.

43. Denner, K., Rainey, W. E., Pezzi, V., Bird, I. M., Bernhardt, R., and Mathis, J. M.23-71996. Differential regulation of 11 beta-hydroxylase and aldosterone synthase in human adrenocortical H295R cells. Mol Cell Endocrinol 121(1), 87-91. 
44. Dihazi, H., Kessler, R., and Eschrich, K.2001. One-step purification of recombinant yeast 6-phosphofructo-2-kinase after the identification of contaminants by MALDITOF MS. Protein Expr.Purif. 21(1), 201-209.

45. Engeland, W. C., Levay-Young, B. K., Rogers, L. M., and Fitzgerald, D.1997. Differential gene expression of cytochrome P450 11 beta-hydroxylase in rat adrenal cortex after in vivo activation. Endocrinology 138(6), 2338-2346.

46. Eustachius, B.1774. Tabulae Anatomicae. Lancisius B ed. Amsterdam.

47. Fang, V. S.1977. Establishment and Characterization of A Strain of Human Adrenal Tumor-Cells That Secrete Estrogen. Proceedings of the National Academy of Sciences of the United States of America 74(3), 1067-1071.

48. Farrell, R. J., Menconi, M. J., Keates, A. C., and Kelly, C. P.2002. P-glycoprotein-170 inhibition significantly reduces cortisol and ciclosporin efflux from human intestinal epithelial cells and T lymphocytes. Alimentary Pharmacology \& Therapeutics 16(5), 1021-1031.

49. Farrell, R. J., Menconi, M. J., and Kelly, C. P.2000. P-glycoprotein (PGP-170) inhibition reduces cortisol and cyclosporin efflux from MDR expressing human Tlymphocytes. Gastroenterology 118(4), A581.

50. Fey, S. J. and Larsen, P. M.2001. 2D or not 2D. Two-dimensional gel electrophoresis. Curr.Opin.Chem.Biol. 5(1), 26-33.

51. Fink, George.2000. Encyclopedia of stress. 1-600. San Diego, Ca, Academic Press.

52. Flens, M. J., Zaman, G. J. R., vanderValk, P., Izquierdo, M. A., Schroeijers, A. B., Scheffer, G. L., vanderGroep, P., deHaas, M., Meijer, C. J. L. M., and Scheper, R. J.1996. Tissue distribution of the multidrug resistance protein. American Journal of Pathology 148(4), 1237-1247.

53. Fountoulakis, M. and Takacs, B.2002. Enrichment and proteomic analysis of lowabundance bacterial proteins. Methods Enzymol. 358, 288-306.

54. Fung, E., Diamond, D., Simonsesn, A. H., and Weinberger, S. R.2003. The use of SELDI ProteinChip array technology in renal disease research. Methods Mol Med. 86, 295-312.

55. Furuhashi, N. and Fang, V. S.1980. A Role of Guanosine 3',5'-Monophosphate in Human-Prolactin-Induced Estrogen Production by Feminizing Adrenal NeoplasticCells. Tohoku Journal of Experimental Medicine 132(1), 87-92.

56. Galeva, N. and Altermann, M.2002. Comparison of one-dimensional and twodimensional gel electrophoresis as a separation tool for proteomic analysis of rat liver microsomes: cytochromes P450 and other membrane proteins. Proteomics. 2(6), 713-722.

57. Galeva, N., Yakovlev, D., Koen, Y., Duzhak, T., and Alterman, M.2003. Direct Identification of Cytochrome P450 Isozymes by Matrix-assisted Laser Desorption/lonization Time of Flight-Based Proteomic Approach. Drug Metab Dispos. 31(4), 351-355.

58. Gardner, D. G., Hane, S., Trachewsky, D., Schenk, D., and Baxter, J. D.30-9-1986. Atrial natriuretic peptide mRNA is regulated by glucocorticoids in vivo. Biochemical and Biophysical Research Communications 139(3), 1047-1054. 
59. Gazdar, A. F., Oie, H. K., Shackleton, C. H., Chen, T. R., Triche, T. J., Myers, C. E., Chrousos, G. P., Brennan, M. F., Stein, C. A., and La Rocca, R. V.1-9-1990. Establishment and characterization of a human adrenocortical carcinoma cell line that expresses multiple pathways of steroid biosynthesis. Cancer Res. 50(17), 5488-5496.

60. Gemmell, R. T., Laychock, S. G., and Rubin, R. P.1977. Ultrastructural and biochemical evidence for a steroid-containing secretory organelle in the perfused cat adrenal gland. J Cell Biol. 72(1), 209-215.

61. Goldstein, L. J., Galski, H., Fojo, A., Willingham, M., Lai, S. L., Gazdar, A., Pirker, R., Green, A., Crist, W., Brodeur, G. M., and .18-1-1989. Expression of a multidrug resistance gene in human cancers. J.Natl.Cancer Inst. 81(2), 116-124.

62. Gottesman, M. M. and Pastan, I.5-9-1988. The multidrug transporter, a double-edged sword. J Biol.Chem. 263(25), 12163-12166.

63. Graham, F. L., Smiley, J., Russell, W. C., and Nairn, R.1977. Characteristics of a human cell line transformed by DNA from human adenovirus type 5. J Gen.Virol. 36(1), 59-74.

64. Gwynne, J. T. and Strauss, J. F., III.1982. The role of lipoproteins in steroidogenesis and cholesterol metabolism in steroidogenic glands. Endocrine Reviews 3(3), 299329.

65. Hagenbuch, B. and Meier, P. J.10-1-2003. The superfamily of organic anion transporting polypeptides. Biochimica et Biophysica Acta 1609(1), 1-18.

66. Hagos, Y., Bahn, A., Asif, A. R., Krick, W., Sendler, M., and Burckhardt, G.1-12-2002. Cloning of the pig renal organic anion transporter 1 (pOAT1). Biochimie 84(12), 12191222.

67. Harvey, PW.1996. The Adrenal in Toxicology. 1-330. London, Taylor and Francis Ltd.

68. Hasegawa, M., Kusuhara, H., Sugiyama, D., Ito, K., Ueda, S., Endou, H., and Sugiyama, Y.2002. Functional involvement of rat organic anion transporter 3 (rOat3; Slc22a8) in the renal uptake of organic anions. Journal of Pharmacology and Experimental Therapeutics 300(3), 746-753.

69. Hinson, J. P., Dawnay, A. B., and Raven, P. W.1995. Why we should give a qualified welcome to ouabain: a whole new family of adrenal steroid hormones? J Endocrinol 146(3), 369-372.

70. Hosoyamada, M., Sekine, T., Kanai, Y., and Endou, H.1999. Molecular cloning and functional expression of a multispecific organic anion transporter from human kidney. Am.J.Physiol 276(1 Pt 2), F122-F128.

71. Hsiang, B., Zhu, Y., Wang, Z., Wu, Y., Sasseville, V., Yang, W. P., and Kirchgessner, T. G.24-12-1999. A novel human hepatic organic anion transporting polypeptide (OATP2). Identification of a liver-specific human organic anion transporting polypeptide and identification of rat and human hydroxymethylglutaryl- CoA reductase inhibitor transporters. The Journal of Biological Chemistry 274(52), 37161-37168.

72. Ideker, T., Thorsson, V., Ranish, J. A., Christmas, R., Buhler, J., Eng, J. K., Bumgarner, R., Goodlett, D. R., Aebersold, R., and Hood, L.4-5-2001. Integrated genomic and proteomic analyses of a systematically perturbed metabolic network. Science 292(5518), 929-934. 
73. Ideker, T., Thorsson, V., Siegel, A. F., and Hood, L. E.2000. Testing for differentiallyexpressed genes by maximum-likelihood analysis of microarray data. J Comput.Biol. 7(6), 805-817.

74. Inaba, M. and Kamata, K.1974. Mode of existence of corticosterone in adrenal cells with reference to storage and secretion. Endocrinol.Jpn. 21(5), 437-447.

75. Jacquemin, E., Hagenbuch, B., Stieger, B., Wolkoff, A. W., and Meier, P. J.1994. Expression cloning of a rat liver $\mathrm{Na}^{+}$-independent organic anion transporter. Proceedings of the National Academy of Sciences USA 91, 133-137.

76. Karssen, A. M., Meijer, O. C., van der Sandt, I. C. J., Lucassen, P. J., de Lange, E. C. M., de Boer, A. G., and de Kloet, E. R.2001. Multidrug resistance P-glycoprotein hampers the access of cortisol but not of corticosterone to mouse and human brain. Endocrinology 142(6), 2686-2694.

77. Kishimoto, Y. and Hoshi, M.1972. Dehydroepiandrosterone sulphate in rat brain: incorporation from blood and metabolism in vivo. J Neurochem. 19(9), 2207-2215.

78. Kondo, H.1985. Immunohistochemical analysis of the localization of neuropeptides in the adrenal gland. Arch Histol.Jpn. 48(5), 453-481.

79. Konig, J., Cui, Y., Nies, A. T., and Keppler, D.2000a. A novel human organic anion transporting polypeptide localized to the basolateral hepatocyte membrane. Am.J.Physiol Gastrointest.Liver Physiol 278(1), G156-G164.

80. Konig, J., Cui, Y., Nies, A. T., and Keppler, D.28-7-2000b. Localization and genomic organization of a new hepatocellular organic anion transporting polypeptide. J Biol.Chem. 275(30), 23161-23168.

81. Kroboth, P. D., Salek, F. S., Pittenger, A. L., Fabian, T. J., and Frye, R. F.1999. DHEA and DHEA-S: a review. J Clin Pharmacol. 39(4), 327-348.

82. Kullak-Ublick, G., Hagenbuch, B., Stieger, B., Schteingart, C., Hofmann, A., Wolkoff, A., and Meier, P.1995. Molecular and functional characterization of an organic anion transporting polypeptide cloned from human liver. Gastroenterology 109(4), 12741282.

83. Kullak-Ublick, G. A., Ismair, M. G., Stieger, B., Landmann, L., Huber, R., Pizzagalli, F., Fattinger, K., Meier, P. J., and Hagenbuch, B.2001. Organic anion-transporting polypeptide B (OATP-B) and its functional comparison with three other OATPs of human liver. Gastroenterology 120(2), 525-533.

84. Kullak-Ublick, G. A., Stieger, B., Hagenbuch, B., and Meier, P. J.2000. Hepatic transport of bile salts. Semin.Liver Dis. 20(3), 273-292.

85. Kullak-Ublick, G. A., Stieger, B., and Meier, P. J.2004. Enterohepatic bile salt transporters in normal physiology and liver disease. Gastroenterology 126(1), 322342.

86. Laurenza, A., Sutkowski, E. M., and Seamon, K. B.1989. Forskolin: a specific stimulator of adenylyl cyclase or a diterpene with multiple sites of action? Trends Pharmacol Sci. 10(11), 442-447.

87. Leibovit, A, Mccombs, W. B., Johnston, D., Mccoy, C. E., and Stinson, J. C.1973. New Human Cancer Cell-Culture Lines .1. Sw-13, Small-Cell Carcinoma of AdrenalCortex. Journal of the National Cancer Institute 51(2), 691-697. 
88. Masereeuw, R., van Pelt, A. P., van Os, S. H., Willems, P. H., Smits, P., and Russel, F. G.2000. Probenecid interferes with renal oxidative metabolism: a potential pitfall in its use as an inhibitor of drug transport. Br.J Pharmacol. 131(1), 57-62.

89. McEwen, B. S.1999. Stress and hippocampal plasticity. Annu.Rev Neurosci. 22, 105122.

90. Meier, P. J., Eckhardt, U., Schroeder, A., Hagenbuch, B., and Stieger, B.1997. Substrate specificity of sinusoidal bile acid and organic anion uptake systems in rat and human liver. Hepatology 26(6), 1667-1677.

91. Meier, P. J. and Stieger, B.2002. Bile salt transporters1. Annu.Rev.Physiol 64, 635661.

92. Moffett, R. B.1-3-1987. Expression of An Endogenous Renin-Angiotensin System by An Adrenal-Cortical Tumor-Cell Line in Culture. Federation Proceedings 46(3), 648.

93. Morohashi, K., Zanger, U. M., Honda, S., Hara, M., Waterman, M. R., and Omura, T.1993. Activation of CYP11A and CYP11B gene promoters by the steroidogenic cellspecific transcription factor, Ad4BP. Molecular Endocrinology 7(9), 1196-1204.

94. Motohashi, H., Sakurai, Y., Saito, H., Masuda, S., Urakami, Y., Goto, M., Fukatsu, A., Ogawa, O., and Inui, K.2002. Gene expression levels and immunolocalization of organic ion transporters in the human kidney. Journal of the American Society of Nephrology 13(4), 866-874.

95. Mountjoy, K. G., Bird, I. M., Rainey, W. E., and Cone, R. D.1994. ACTH induces upregulation of ACTH receptor mRNA in mouse and human adrenocortical cell lines. Mol.Cell Endocrinol. 99(1), R17-R20.

96. Muller, M. B., Keck, M. E., Binder, E. B., Kresse, A. E., Hagemeyer, T. P., Landgraf, R., Holsboer, F., and Uhr, M.2003. ABCB1 (MDR1)-type P-glycoproteins at the bloodbrain barrier modulate the activity of the hypothalamic-pituitary-adrenocortical system: implications for affective disorder. Neuropsychopharmacology 28(11), 1991-1999.

97. Nagata, Y., Kusuhara, H., Endou, H., and Sugiyama, Y.2002. Expression and Functional Characterization of Rat Organic Anion Transporter 3 (rOat3) in the Choroid Plexus. Molecular Pharmacology 61(5), 982-988.

98. Neville, A. M and O'Hare, M.1982. The Human Adrenal Cortex. Pathology and Biology-An Integrated approach. 139-144. Berlin, Germany, Springer-Verlag.

99. Nicholls, M. G., Richards, A. M., Lewis, L. K., and Yandle, T. G.25-11-1995. Ouabain: a new steroid hormone? Lancet 346(8987), 1381-1382.

100. Nieschlag, E., Loriaux, D. L., Ruder, H. J., Zucker, I. R., Kirschner, M. A., and Lipsett, M. B.1973. The secretion of dehydroepiandrosterone and dehydroepiandrosterone sulphate in man. J Endocrinol 57(1), 123-134.

101. Race, J. E., Grassl, S. M., Williams, W. J., and Holtzman, E. J.1999. Molecular cloning and characterization of two novel human renal organic anion transporters (hOAT1 and hOAT3). Biochemical and Biophysical Research Communications 255, 508-514.

102. Rainey, W. E., Bird, I. M., and Mason, J. I.1994. The Nci-H295 Cell-Line - A Pluripotent Model for Human Adrenocortical Studies. Molecular and Cellular Endocrinology 100(1-2), 45-50. 
103. Rainey, W. E., Bird, I. M., Sawetawan, C., Hanley, N. A., Mccarthy, J. L., Mcgee, E. A., Wester, R., and Mason, J. I.1993. Regulation of Human Adrenal Carcinoma Cell (Nci-H295) Production of C19 Steroids. Journal of Clinical Endocrinology and Metabolism 77(3), 731-737.

104. Rainey, W. E., Carr, B. R., Sasano, H., Suzuki, T., and Mason, J. I.2002. Dissecting human adrenal androgen production. Trends Endocrinol Metab 13(6), 234-239.

105. Rao, M. L., Rao, G. S., Holler, M., Breuer, H., Schattenberg, P. J., and Stein, W. D.1976. Uptake of cortisol by isolated rat liver cells. A phenomenon indicative of carrier-mediation and simple diffusion. Hoppe Seylers.Z.Physiol Chem. 357(4), 573584.

106. Regelson, W., Loria, R., and Kalimi, M.31-5-1994. Dehydroepiandrosterone (DHEA)-the "mother steroid". I. Immunologic action. Annals of the New York Academy of Sciences 719, 553-563.

107. Reid, G., Wolff, N. A., Dautzenberg, F. M., and Burckhardt, G.1998. Cloning of a human renal $p$-aminohippurate transporter, hROAT1. Kidney and Blood Pressure Research 21, 233-237.

108. Riabowol, K. T., Fink, J. S., Gilman, M. Z., Walsh, D. A., Goodman, R. H., and Feramisco, J. R.3-11-1988. The catalytic subunit of cAMP-dependent protein kinase induces expression of genes containing cAMP-responsive enhancer elements. Nature 336(6194), 83-86.

109. Rosol, T. J., Yarrington, J. T., Latendresse, J., and Capen, C. C.2001. Adrenal gland: Structure, function, and mechanisms of toxicity. Toxicologic Pathology 29(1), 41-48.

110. Rozen, S. and Skaletsky, H.2000. Primer3 on the WWW for general users and for biologist programmers. Methods Mol Biol. 132, 365-386.

111. Rust, W., Stedronsky, K., Tillmann, G., Morley, S., Walther, N., and Ivell, R.1998. The role of SF-1/Ad4BP in the control of the bovine gene for the steroidogenic acute regulatory (StAR) protein. J Mol Endocrinol 21(2), 189-200.

112. Sandhoff, T. W., Hales, D. B., Hales, K. H., and McLean, M. P.1998. Transcriptional regulation of the rat steroidogenic acute regulatory protein gene by steroidogenic factor 1. Endocrinology 139(12), 4820-4831.

113. Sauvant, C., Holzinger, H., and Gekle, M.2003. Short-term regulation of basolateral organic anion uptake in proximal tubular opossum kidney cells: prostaglandin E2 acts via receptor-mediated activation of protein kinase A. J Am.Soc.Nephrol 14(12), 30173026.

114. Schinkel, A. H., Mayer, U., Wagenaar, E., Mol, C. A., van Deemter, L., Smit, J. J., van der Valk, M. A., Voordouw, A. C., Spits, H., van Tellingen, O., Zijlmans, J. M., Fibbe, W. E., and Borst, P.15-4-1997. Normal viability and altered pharmacokinetics in mice lacking mdr1-type (drug-transporting) P-glycoproteins. Proc.Natl.Acad.Sci.U.S.A 94(8), 4028-4033.

115. Sekine, T., Cha, S. H., Hosoyamada, M., Kanai, Y., Watanabe, N., Furuta, Y., Fukuda, K., Igarashi, T., and Endou, H.1998a. Cloning, functional characterization, and localization of a rat renal Na+-dicarboxylate transporter. Am.J Physiol $275(2 \mathrm{Pt}$ 2), F298-F305.

116. Sekine, T., Cha, S. H., Tsuda, M., Apiwattanakul, N., Nakajima, N., Kanai, Y., and Endou, H.12-6-1998b. Identification of multispecific organic anion transporter 2 expressed predominantly in the liver. FEBS Letters 429(2), 179-182. 
117. Sekine, T., Watanabe, N., Hosoyamada, M., Kanai, Y., and Endou, H.1997. Expression cloning and characterization of a novel multispecific organic anion transporter. The Journal of Biological Chemistry 272(30), 18526-18529.

118. Sharom, F. J., Liu, R., Romsicki, Y., and Lu, P.6-12-1999. Insights into the structure and substrate interactions of the P-glycoprotein multidrug transporter from spectroscopic studies. Biochimica et Biophysica Acta 1461(2), 327-345.

119. Sheikh, M. I. and Stahl, M.1977. Characteristics of accumulation of probenecid by rabbit kidney cortical slices. Am.J Physiol 232(6), F513-F523.

120. Sheikh, M. I., Stahl, M., and Jacobsen, C.1979. A comparative study on the accumulation of probenecid and analogues in rabbit kidney tubules in vitro. Biochem.Pharmacol 28(1), 15-22.

121. Simonson, G. D., Vincent, A. C., Roberg, K. J., Huang, Y., and Iwanij, V.1994. Molecular cloning and characterization of a novel liver-specific transport protein. Journal of Cell Science 107, 1065-1072.

122. Simpson, E. R. and Waterman, M. R.1983. Regulation by ACTH of steroid hormone biosynthesis in the adrenal cortex. Can.J Biochem.Cell Biol. 61(7), 692-707.

123. Simpson, E. R. and Waterman, M. R.1988. Regulation of the synthesis of steroidogenic enzymes in adrenal cortical cells by ACTH. Annu.Rev Physiol 50, 427440 .

124. St Pierre, M. V., Hagenbuch, B., Ugele, B., Meier, P. J., and Stallmach, T.2002. Characterization of an organic anion-transporting polypeptide (OATP-B) in human placenta. Journal of Clinical Endocrinology and Metabolism 87(4), 1856-1863.

125. Stalmans, W. and Laloux, M.1979. Glucocorticoids and hepatic glycogen metabolism. Monogr Endocrinol 12, 517-533.

126. Steffgen, J., EhrhartBornstein, M., Bahr, V., Herkommer, B., Sippell, W. G., GuseBehling, H., Franz, H. E., Scherbaum, W. A., and Bornstein, S. R.1996. Evidence for the involvement of an anion exchanger in cortisol release from bovine adrenocortical cells. Cellular Physiology and Biochemistry 6(1-2), 82-90.

127. Steffgen, J., Rohrbach, S., Beery, E., Ersoy, D., Jarry, H., Metten, M., Bornstein, S. R., Muller, G. A., and Burckhardt, G.1999. Demonstration of a probenecid-inhibitable anion exchanger involved in the release of cortisol and cAMP and in the uptake of $p$ aminohippurate in bovine adrenocortical cells. Cellular Physiology and Biochemistry 9(2), 72-80.

128. Stocco, D. M.26-6-2000. Intramitochondrial cholesterol transfer. Biochimica et Biophysica Acta 1486(1), 184-197.

129. Sugiyama, D., Kusuhara, H., Shitara, Y., Abe, T., Meier, P. J., Sekine, T., Endou, H., Suzuki, H., and Sugiyama, Y.2001. Characterization of the efflux transport of 17betaestradiol-D-17beta- glucuronide from the brain across the blood-brain barrier. Journal of Pharmacology and Experimental Therapeutics 298(1), 316-322.

130. Sun, W., Wu, R. R., van Poelje, P. D., and Erion, M. D.4-5-2001. Isolation of a family of organic anion transporters from human liver and kidney. Biochemical and Biophysical Research Communications 283(2), 417-422.

131. Suzuki, S., Machida, I., Hayashi, H., and Wakusawa, S.2003. Reduction of MDR3 mRNA levels by forskolin in Chang liver cells. Anticancer Res 23(4), 3373-3378. 
132. Sweet, D. H., Chan, L. M., Walden, R., Yang, X. P., Miller, D. S., and Pritchard, J. B.17-12-2002. Organic Anion Transporter 3 (Slc22a8) is a Dicarboxylate Exchanger Indirectly Coupled to the Na+ Gradient. Am.J.Physiol Renal Physiol , 763-769.

133. Sweet, D. H., Wolff, N. A., and Pritchard, J. B.1997. Expression cloning and characterization of a novel organic anion transporter from rat kidney. The Faseb Journal 11, A278.

134. Tamai, I., Nezu, J., Uchino, H., Sai, Y., Oku, A., Shimane, M., and Tsuji, A.24-6-2000. Molecular identification and characterization of novel members of the human organic anion transporter (OATP) family. Biochemical and Biophysical Research Communications 273(1), 251-260.

135. Thiebaut, F., Tsuruo, T., Hamada, H., Gottesman, M. M., Pastan, I., and Willingham, M. C.1987. Cellular localization of the multidrug-resistance gene product Pglycoprotein in normal human tissues. Proc.Natl.Acad.Sci.U.S.A 84(21), 7735-7738.

136. Thiebaut, F., Tsuruo, T., Hamada, H., Gottesman, M. M., Pastan, I., and Willingham, M. C.1989. Immunohistochemical localization in normal tissues of different epitopes in the multidrug transport protein P170: evidence for localization in brain capillaries and crossreactivity of one antibody with a muscle protein. J Histochem.Cytochem. 37(2), 159-164.

137. Thompson, E. B.1-7-1995. Steroid-Hormones - Membrane Transporters of SteroidHormones. Current Biology 5(7), 730-732.

138. Ueda, K., Okamura, N., Hirai, M., Tanigawara, Y., Saeki, T., Kioka, N., Komano, T., and Hori, R.5-12-1992. Human P-Glycoprotein Transports Cortisol, Aldosterone, and Dexamethasone, But Not Progesterone. Journal of Biological Chemistry 267(34), 24248-24252.

139. Ueda, K., Pastan, I., and Gottesman, M. M.25-12-1987. Isolation and sequence of the promoter region of the human multidrug-resistance (P-glycoprotein) gene. J Biol.Chem. 262(36), 17432-17436.

140. Ueno, M., Nakashima, J., Akita, M., Ban, S. I., Nakanoma, T., lida, M., and Deguchi, N.2001. Characterization of a newly established cell line derived from human adrenocortical carcinoma. Int.J.Urol. 8(1), 17-22.

141. Ugele, B., St Pierre, M. V., Pihusch, M., Bahn, A., and Hantschmann, P.2003. Characterization and identification of steroid sulfate transporters of human placenta. Am.J.Physiol Endocrinol.Metab 284(2), E390-E398.

142. Ullrich, K. J., Rumrich, G., Papavassiliou, F., and Hierholzer, K.1991. Contraluminal p-aminohippurate transport in the proximal tubule of the rat kidney. VIII. Transport of corticosteroids. Pflügers Archives 418, 371-382.

143. van Aubel, R. A., Peters, J. G., Masereeuw, R., Van Os, C. H., and Russel, F. G.2000. Multidrug resistance protein mrp2 mediates ATP-dependent transport of classic renal organic anion p-aminohippurate. Am.J.Physiol Renal Physiol 279(4), F713-F717.

144. van Kalken, C. K., Broxterman, H. J., Pinedo, H. M., Feller, N., Dekker, H., Lankelma, J., and Giaccone, G.1993. Cortisol is transported by the multidrug resistance gene product P-glycoprotein. Br.J.Cancer 67(2), 284-289.

145. van Montfoort, J. E., Hagenbuch, B., Groothuis, G. M., Koepsell, H., Meier, P. J., and Meijer, D. K.2003. Drug uptake systems in liver and kidney. Curr.Drug Metab 4(3), 185-211. 
146. van Montfoort, J. E., Schmid, T. E., Adler, I. D., Meier, P. J., and Hagenbuch, B.19-82002. Functional characterization of the mouse organic-anion-transporting polypeptide 2. Biochimica et Biophysica Acta 1564(1), 183-188.

147. Vankalken, C. K., Broxterman, H. J., Pinedo, H. M., Feller, N., Dekker, H., Lankelma, J., and Giaccone, G.1993. Cortisol Is Transported by the Multidrug Resistance GeneProduct P-Glycoprotein. British Journal of Cancer 67(2), 284-289.

148. Vermeulen, A., Schelfhout, W., and De Sy, W.1982. Plasma androgen levels after subcapsular orchiectomy or estrogen treatment for prostatic carcinoma. Prostate 3(2), 115-121.

149. Vinson, G. P. and .1992. The adrenal Gland. Hinson, J. P. Blood flow and the hormone secretion in the adrenal gland. 2nd Edn, 71-88. New York, Academic Press.

150. Vlasuk, G. P., Ghrayeb, J., Ryan, D. E., Reik, L., Thomas, P. E., Levin, W., and Walz, F. G., Jr.16-2-1982. Multiplicity strain differences, and topology of phenobarbitalinduced cytochromes P-450 in rat liver microsomes. Biochemistry 21(4), 789-798.

151. Whitehouse, B. J. and Vinson, G. P.1971. Compartmental arrangement of steroid precursors and the control of steroid hormone secretion in rat adrenal tissue in vitro. Acta Endocrinol (Copenh) 68(3), 467-476.

152. Wilson, J. A. and Foster, D. W.1992. Williams Textbook of Endocrinology. The Adrenal Cortex. 8th Ed, 489-619.

153. Wolff, N. A., Werner, A., Burkhardt, S., and Burckhardt, G.1997. Expression cloning and characterization of a renal organic anion transporter from winter flounder. FEBS Letters 417, 287-291.

154. Zenkert, S., Schubert, B., Fassnacht, M., Beuschlein, F., Allolio, B., and Reincke, M.2000. Steroidogenic acute regulatory protein mRNA expression in adrenal tumours. Eur.J.Endocrinol. 142(3), 294-299.

155. Zhou, F., Tanaka, K., Soares, M. J., and You, G.2003. Characterization of an organic anion transport system in a placental cell line. Am.J Physiol Endocrinol Metab 285(5), E1103-E1109. 


\section{ACKNOWLEDGMENTS}

This dissertation was written while I was working at University of Göttingen in a collaborative project of Department of Nephrology \& Rheumatology and Department of Vegetative Physiology.

I would like to express my gratitude to my supervisors Prof. Dr. G. Burckhardt, and Prof. Dr. G. A. Müller, for their intensive scientific guidance over this period. Their expertise, understanding, and patience, added considerably to my graduate experience. I appreciate their vast knowledge and skills.

My sincere thanks to Prof. Dr. R. Hardeland for supervising my PhD thesis and fruitful suggestions during experimental work and to Prof. Dr. D. Gradmann for being co-referent of my dissertation in the Faculty of Biology at University of Göttingen.

To my advisors, Dr. Y. Hagos and Prof. Dr. R. W. Grunewald, I would like to express my gratitude for their patience, understanding, and constructively critical eye during the entire course of my doctoral work. Appreciation also goes to Dr. H. Dihazi for providing me opportunity to work in his proteomic group and his continuous guidance.

Prof. I. Sabolic, M. ljubojevic (Zagreb, Croatia) Prof Jarry and M. Metten, Dr. A. Bahn, Dr. N. Wolff, N. Bakhiya, Dr. Y. Wessels and Dr. Langenburg for profitable cooperation.

Special thanks go to S. Schindelmann for providing excellent lab environment in Dept. of Physiology and E. Brunst-Knoblich for her excellent help in Dept. of Nephrology.

Thanks to E. Tellen, S. Petzke, G. Dallmeyer, R. Schirmer, and U. Fischer, for their professional help during my stay in Physiology, J. Langer for help in literature collection and administrative work.

Thanks to all my friends in Germany and Pakistan for their indispensable support during all this period. Recognition to the financial assistance of Graduate College 335, University of Göttingen, funded by DFG.

Last but not least, I thank my wife and my parents, for their patience and encouragement during these years. 


\section{BIOGRAPHY}

Name:

Date of birth:

Place of Birth:

Citizenship:

1979 - 1990:

1990 - 1992:

1992 - 1996:

$1997-2000$ :

2001-2004:
Abdul Rahman Asif

11.07.1973

Kunjah (Gujrat) Pakistan

Pakistan

Primary and High school, (Prescience), Kunjah, Gujrat, Pakistan

F.Sc. (Premedical) Govt. Zamindara College, Gujrat, Pakistan

B.S.Ed. (Chemsitry, Zoology, Botany, Education)

Federal College of Education Islamabad, affiliated to

University of The Punjab, Lahore, Pakistan.

Thesis title: "Evaluation of the difference in educational facilities to the boys and girls from their parents".

M.Sc. (Biochemistry),

University of Agriculture, Faisalabad, Pakistan.

Thesis title: "Antihepatotoxic evaluation of Butea

monosperema against liver damage induced by paracetamol and carbon tetrachloride in rats".

Ph D (Biology),

Georg-August-Universität, Göttingen, Germany

Member of the DFG-funded Graduiertenkolleg 335, entitled:

"Clinical and cellular and molecular biology of the internal organs"

Thesis title: "Role of transport systems in cortisol release from human adrenal cells". 